UNIVERSIDADE DE SÃO PAULO

FACULDADE DE ARQUITETURA E URBANISMO

PROGRAMA DE PÓS-GRADUAÇÃO EM ARQUITETURA E URBANISMO

ANALU GARCIA BORGES

TERRITÓRIO EDUCATIVO: AS PRÁTICAS EDUCATIVAS DA EXTENSÃO UNIVERSITÁRIA E DOS COLETIVOS CULTURAIS NA PERIFERIA DE SÃO PAULO 


\title{
TERRITÓRIO EDUCATIVO: AS PRÁTICAS EDUCATIVAS DA EXTENSÃO UNIVERSITÁRIA E DOS COLETIVOS CULTURAIS NA PERIFERIA DE SÃO PAULO
}

\author{
Exemplar revisado e alterado em relação à versão \\ original, sob responsabilidade da autora e anuência do \\ orientador. A versão original, em formato digital, ficará \\ arquivada na Biblioteca da Faculdade. \\ São Paulo, 25 de fevereiro de 2021. \\ Dissertação apresentada como requisito para obtenção do \\ título de Mestre em Arquitetura e Urbanismo pela \\ Universidade de São Paulo. \\ Área de Concentração: Planejamento Urbano e Regional \\ Orientador: Prof. Dr. Jorge Bassani
}

São Paulo 
Autorizo a reprodução e divulgação total ou parcial deste trabalho, por qualquer meio convencional ou eletrônico, para fins de estudo e pesquisa, desde que citada a fonte.

E-mail: garciaborgesanalu@gmail.com

Catalogação na Publicação

Serviço Técnico de Biblioteca

Faculdade de Arquitetura e Urbanismo da Universidade de São Paulo

Borges, Analu

TERRITÓRIO EDUCATIVO: as práticas educativas da extensão universitária e dos coletivos culturais na periferia de São Paulo / Analu Borges; orientador Jorge Bassani. - São Paulo, 2021.

$219 \mathrm{f}$.

Dissertação (Mestrado) - Faculdade de Arquitetura e Urbanismo da Universidade de São Paulo. Área de

concentração: Planejamento Urbano e Regional.

1. Coletivos Culturais. 2. Extensão Universitária. 3. Práticas Educativas. 4. Território. I. Bassani, Jorge, orient. II. Título.

Elaborada eletronicamente através do formulário disponivel em: $<$ http://www.fau.usp.br/fichacatalografica/ $>$ 


\section{TERRITÓRIO EDUCATIVO AS PRÁTICAS EDUCATIVAS DA EXTENSÃO UNIVERSITÁRIA E DOS COLETIVOS CULTURAIS NA PERIFERIA DE SÃO PAULO}

Dissertação apresentada como requisito para obtenção do título de Mestre em Arquitetura e Urbanismo pela Universidade de São Paulo.

Área de Concentração: Planejamento Urbano e Regional

Orientador: Prof. Dr. Jorge Bassani

Data de aprovação: 15/01/2021

Banca Examinadora:

Presidente: Prof. Dr. Jorge Bassani

Instituição: FAU-USP

Julgamento: Aprovada

Prof ${ }^{\mathrm{a}}$. Dr ${ }^{\mathrm{a}}$. Silvia Lopes Raimundo

Instituição: GEO-UNIFESP

Julgamento: Aprovada

Prof Dr. Bruno Mello

Instituição: FAU-UFRGS

Julgamento: Aprovada 
In memoriam

À minha avó Reinita, mulher do campo, contadora de histórias do rádio, fazedora de coisas, artes e sabores, viajante de carroças e carrocerias, a avó e mãe que quis que os filhos e netos "tivessem estudo" e nos ensinou a coragem, o riso e a fé, com amor. 


\section{RESUMO}

BORGES, Analu Garcia. Território Educativo: as práticas educativas da extensão universitária e dos coletivos culturais na periferia de São Paulo. 2021. Dissertação (Mestrado) - Faculdade de Arquitetura e Urbanismo da Universidade de São Paulo, São Paulo, 2021.

A partir de 2011 houve o início de um processo colaborativo de construção de conhecimento em Perus, distrito da região noroeste de São Paulo, envolvendo a Comunidade Cultural Quilombaque, agentes locais e o Núcleo de Estudos da Paisagem da Faculdade de Arquitetura e Urbanismo da Universidade de São Paulo (NEP/USP). No outro extremo do município, onde se localiza o bairro do Bororé, houve também a parceria entre o coletivo ecocultural Casa Ecoativa, a escola estadual Professor Adrião Bernardes e o Grupo de Estudos de Mapografias Urbanas da Faculdade de Arquitetura e Urbanismo da Universidade de São Paulo (GeMAP/USP). Ambos os territórios são denominados de “educadores” por seus agentes. A pesquisa busca compreender, por meio de uma abordagem qualitativa, a relação entre educação e território a partir das práticas apontadas. Para tanto, foi realizada uma investigação teórica sobre os conceitos de território e educação, seus conteúdos e classificações, bem como uma pesquisa de campo para compreender a aplicação desses conceitos nas práticas dos coletivos em parceria com a extensão universitária. Conclui-se que a atuação pedagógica e política desses coletivos em parceria com projetos de extensão universitária, por meio de processos dialógicos, opera como um instrumento potente para serem pensadas e construídas novas formas de gestão, existência e sobrevivência nas cidades em permanente construção.

Palavras-chave: coletivos culturais, extensão universitária, práticas educativas, território. 


\begin{abstract}
BORGES, Analu Garcia. Educational Territory: the educational practices of university extension and cultural collectives in the periphery of São Paulo. 2021. Dissertation (Master) Faculty of Architecture and Urbanism of São Paulo, São Paulo, 2021.

As of 2011, a collaborative process of knowledge construction began in Perus, a district in the northwest region of São Paulo, involving the Quilombaque Cultural Community, local agents and the Center for Landscape Studies at the Faculty of Architecture and Urbanism at the University of São Paulo (NEP / USP). At the other end of the municipality, where the Bororé neighborhood is located, there was also a partnership between the ecocultural collective Casa Ecoativa, the state school Professor Adrião Bernardes and the Urban Mapography Study Group at the Faculty of Architecture and Urbanism at the University of São Paulo (GeMAP / USP). Both territories are called "educational territory" by their agents. The research seeks to understand, through a qualitative approach, the relationship between education and territory from the mentioned experiences. For this purpose, a theoretical investigation was carried out on the concepts of territory and education, their contents and classifications, as well as a field research to understand the application of these concepts in the practices of collectives in partnership with the university extension. We conclude that the pedagogical and political performance of these collectives in partnership with university extension projects, through dialogic processes, operates as a powerful instrument so that new forms of management, existence and survival can be thought and built in the cities under permanent construction.
\end{abstract}

Key words: cultural collectives, university extension, educational practices, territory. 


\section{AGRADECIMENTOS}

Aos meus pais, pelo amor, dedicação, carinho e bondade, ao apoio em todos os momentos da vida. Ao meu irmão, pela amizade, respeito e por me inspirar a ter disciplina e força de vontade.

Ao meu companheiro Jean, pelo incentivo e apoio desde o primeiro momento. Pela amizade e respeito incondicionais. Pelo amor e paciência em todos os momentos, especialmente nos mais difíceis. Pela caminhada de crescimento que me proporciona todos os dias. Por sua presença indispensável nessa caminhada.

À professora Karina Leitão por abrir a possibilidade de diálogo com uma desconhecida. Aquela conversa me presentou com o meu orientador Jorge Bassani. À professora Camila D’Ottaviano, pela generosidade desde o começo, pelo olhar inclusivo e pelas oportunidades de me "territorializar" na FAU para compreender seus códigos, desde a monitoria na graduação, pelo convite para colaborar nos eventos e participar do grupo de estudos com seus orientandos.

À Cilda, por me trazer sempre as melhores notícias com alegria e sorriso no rosto! Espero que muitos alunos "perdidos” te encontrem pelo caminho.

Ao meu orientador Jorge Bassani, por me ensinar através dos gestos, da conduta, da palavra e da generosidade o que é trabalhar em grupo, o que é ser justo, ético e o que é trabalhar com seriedade e leveza ao mesmo tempo. Obrigada por me ensinar a refletir. Obrigada por me ensinar a perder o medo de ouvir críticas construtivas e compreender o processo todo como pedagógico. Obrigada pela paciência em tentar me mostrar o caminho da praticidade. Obrigada pela sensibilidade dos silêncios que foram generosos nos momentos em que eu não teria estrutura para ouvir qualquer "palavra”, levarei comigo que o observar, o ouvir e o esperar "o tempo do outro" também ensinam. Obrigada pela generosidade em abrir espaços de aprendizagem (na extensão, no ensino e na pesquisa), através dos quais eu percorri um caminho de amadurecimento e conhecimento. Obrigada pelo “convite” para conhecer São Paulo, para me conhecer através de São Paulo, através da extensão universitária. Obrigada por confiar em mim em todos os momentos, por me dar o benefício da dúvida e da escolha e, acima de tudo, pela parceria nos desafios na fase final do mestrado. Obrigada por abrir todas as portas que eu precisei para aprender a começar a me formar como pesquisadora.

Ao professor Euler Sandeville Júnior, por me mostrar que o ensino, a pesquisa e a extensão podem (e devem) ser feitos com amor, com o corpo e com a alma. Obrigada pela generosidade e afeto desinteressados - gestos e sentimentos difíceis de serem praticados 
genuinamente “dentro dos muros” da academia. Obrigada por me possibilitar conhecer pessoas, histórias, lutas e Perus, essa territorialização me fez repensar todo o meu percurso na FAU.

Às meninas (“faurasteiras”) - Marina, Helô, Dri, Mari, Glaucia, Deiny pelos happy hours presenciais e virtuais, pela divisão das angústias, dúvidas, acertos, pelas risadas e pelo carinho. Em especial à Marina que esteve comigo lado a lado, no "busão" e nas correções de texto, nos treinamentos de oratória, nas correções objetivas e carinhosas que só uma amiga e pesquisadora generosa pode ceder a outra amiga. À minha conterrânea Elizabeth Othon, "Bethinha”, pela generosidade das dicas passadas a mim, uma mato-grossense recém-chegada no território da pós-graduação na FAUUSP.

Ao GeMAP - e às amizades que fiz por meio dele, como a Helô e a Jéssica - que me proporcionou "aprender fazendo", experienciando, vivenciando, pisando no território, transitando entre o grupo dos arquitetos e mundo dos geógrafos, por meio da extensão universitária na Ilha do Bororé. Às meninas da Paisagem - Talita e Ana, que me acolheram no laboratório mais alto astral da FAU (o Quapá) e me trouxeram outras visões de mundo e de pesquisa. Esse contato me fez querer juntar todos os laboratórios e grupos em um só. Aos colegas que fiz pelo caminho - Flávia, Ana Maria, Heitor, Helô, Renata, Hernan, Carina, pelos debates, pela convivência e compartilhamento de dúvidas, angústias e piadas. O que seria desse caminho sem a zoeira dos memes e o riso do desespero?

Ao Jai, JC, Tim, Adrielle, Kawan, Valéria pelos diálogos, pelo carinho, respeito e pelos momentos de aprendizado. Por me permitirem sonhar junto com vocês. Ao Fofão, Almir, à Regina, Mário por compartilharem suas histórias comigo e me possibilitarem um processo de conscientização e amadurecimento.

À Milla, pela amizade, pelo apoio, pelas risadas e pelo ótimo trabalho realizado ao ilustrar digitalmente com sensibilidade, comprometimento e cuidado meus rabiscos e ideias. Seu apoio foi essencial nessa reta final para que meu trabalho saísse com o gosto de afeto que eu gostaria que ele saísse. 


\section{LISTA DE FIGURAS}

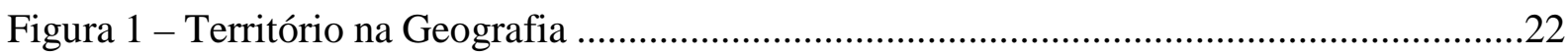

Figura 2 - Território na Ciência Política ..............................................................................23

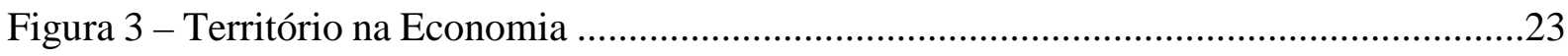

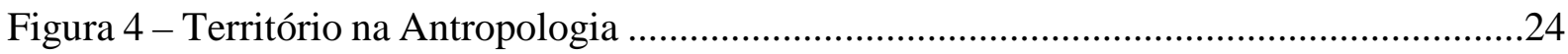

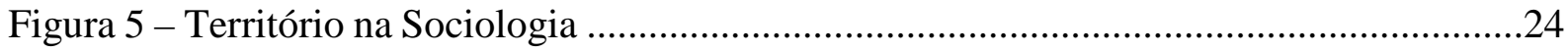

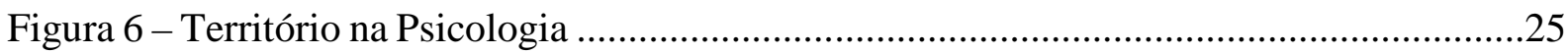

Figura 7 - Ilustração da paisagem do bairro de Perus em 2019 ...............................................43

Figura 8 - Ilustração representando a segregação socioespacial ............................................44

Figura 9 - Ensino-aprendizagem na escola tradicional “conteudista” ....................................63

Figura 10 - Ilustração do processo de ensino-aprendizagem .................................................63

Figura 11 - Ilustração com esquema sobre a Teoria Sociocultural de Vygostky .....................69

Figura 12 - Ilustração com esquema sobre a formação de conceitos em Vygostky ...................70

Figuras 13 - Ilustração com esquema da ação cultural dialógica, de Paulo Freire .....................71

Figuras 14 - Interação com o território e a apropriação de significados ...................................72

Figura 15 - Territorialização das práticas educativas e a formação de conceitos ......................73

Figura 16 - Ilustração com a representação da educação formal (escolar) ...............................75

Figura 17 - Educação não-formal no âmbito da cultura .........................................................78

Figura 18 - Educação não-formal no âmbito da cultura ...........................................................78

Figura 19 - Educação comunitária, no âmbito da cultura .....................................................83

Figura 20 - Educação social, no âmbito da cultura e do meio ambiente ...................................84

Figura 21 - Educação social, no âmbito do lazer e meio ambiente ..........................................85

Figura 22 - Ilustração com a representação da educação social, no âmbito da cultura ..............85

Figura 23 - Linha do tempo com ilustração de fatos relevantes na escala global .....................102

Figura 24 - Linha - ciências naturais e humanas .................................................................102

Figura 25 - Linha do tempo com ilustração de fatos relevantes para a educação .....................103

Figura 26 - Linha do tempo com ilustração de fatos relevantes na escala local .......................103

Figura 27 - Distrito do Grajaú e a mancha urbana mais ao norte e a área rural ao sul ..............114

Figura 28 - Material compartilhado com a Casa Ecoativa ..................................................115

Figura 29 - Material compartilhado com a Casa Ecoativa ..................................................116

Figura 30 - Material compartilhado com a Casa Ecoativa ..................................................117

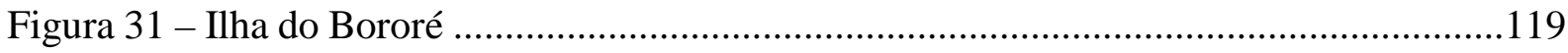


Figura 32 - Ilustração da paisagem da travessia da represa por meio da balsa 119

Figura 33 - Ilustração - aspectos da ruralidade da Ilha do Bororé .120

Figura 34 -Pontos do território do Bororé que emergiram das falas dos participantes 124

Figura 35 - Placa na entrada da ilha do Bororé, após a travessia da primeira Balsa 125

Figura 36 - Chegada da Primeira Balsa na ilha do Bororé 126

Figura 37 - Mapa de Intervenções e Processos do Projeto Imargem no Grajaú 128

Figura 38 - Verso do Mapa de Intervenções e Processos do Projeto Imargem no Grajaú 128

Figura 39 - Trecho do Mapa de Intervenções do projeto Imargem 129

Figura 40 - Mural Mapa na Ilha do Bororé 129

Figura 41 - Foto do Mural-Memória, elaborado em 2012 pelo coletivo Imargem 130

Figura 42 - Capela de São Sebastião e paisagem da ilha do Bororé 130

Figura 43 - Quadro com fotos das atividades comunitárias na ilha do Bororé 131

Figura 44 - Fotos dos festejos da comunidade do Bororé 131

Figura 45 - Casa Ecoativa, na Ilha do Bororé, 2019 .132

Figura 46 - Roda com Tião Carvalho na Casa Ecoativa e crianças brincando, 2019 134

Figura 47 - Roda Tião Carvalho na Casa Ecoativa, 2019 134

Figura 48 - Atividade de “cartograffiti”, 2019 135

Figura 49 - Pintura do mapa do Bororé, o programa Ecoativa Férias, 2019. 135

Figura 50 -Mapa do Bororé pintado durante a atividade da Ecoativa Férias, 2019 136

Figura 51 - Material compartilhado com a Casa Ecoativa 139

Figura 52 -Escola Estadual Professor Adrião Bernardes, na Ilha do Bororé, 2019 142

Figura 53 - Mural feito pelo Imargem no muro da estrada velha do Bororé 143

Figura 54 - Graffitis ao longo dos muros no trajeto da escola até a Ecoativa 144

Figura 55 -Escola Estadual Professor Adrião Bernardes, na Ilha do Bororé, 2019 ..... 144

Figura 56 -Linha do tempo sobre o Bororé e o projeto Bororé ao Mundo 145

Figura 57 - Atividade de mapeamento realizada pelos alunos da EU 146

Figura 58 - Oficinas de cartografia na E. E. Adrião Bernardes 146

Figura 59 - Atividade de mapeamento realizada pelos alunos da EU 147

Figura 60 - Oficina de mapeamento com a ONG Teto, 2019 .............................................148

Figura 61 - Atividade com os alunos do Adrião Bernardes ...................................................148

Figura 62 - Atividade com os alunos do Adrião Bernardes ................................................149

Figura 63 - Participantes do projeto de extensão no trajeto da escola até a Ecoativa ..............149

Figura 64 - Atividade preparatória de reconhecimento do território .150 
Figura 65 - Atividade da Ecoativa Férias, 2019

Figura 66 -Entrevista com Dona Sueli, moradora antiga do Bororé .152

Figura 67 - Entrevista com a Dona Eva e o Sr. Nelson .153

Figura 68 - Mostra Cultural da Escola Adrião Bernardes, 2019 153

Figura 69 - Site Bororé ao Mundo, 2019 .154

Figura 70 - Marcação dos locais encontrados durante a entrevista da Dona Sueli 155

Figura 71 - Dados coletados durante entrevista 155

Figura 72 - Representação dos agentes da Extensão Universitária .156

Figura 73 - Nuvem de palavras a partir dos relatos dos participantes do Bororé ..... 157

Figura 74 - Trecho do Mapa de Intervenções do projeto Imargem 158

Figura 75 - Trecho do Mapa de Intervenções do projeto Imargem 159

Figura 76 - Ilustração com a representação da Estação Ferroviária de Perus 168

Figura 77 - Ilustração com a representação da Fábrica de Cimento Portland Perus 169

Figura 78 - Foto da Fábrica de Cimento de Perus .171

Figura 79 - Foto dos operários da Fábrica de Cimento de Perus .172

Figura 80 - Foto dos operários da Fábrica de Cimento de Perus 173

Figura 81 - Greve dos operários da Fábrica de Cimento de Perus 173

Figura 82 -Greve dos operários da Fábrica de Cimento de Perus 174

Figura 83 - Logotipo da Comunidade Cultural Quilombaque 175

Figura 84 - Comunidade Cultural Quilombaque 176

Figura 85 - Ilustração com a representação do Museu Territorial Tekoa Jopo’i 178

Figura 86 - Linha do tempo sobre a Universidade Livre e Colaborativa 179

Figura 87 - Pontos importantes do território de Perus 181

Figura 88 - Material gráfico produzido pela Universidade Livre Colaborativa (ULC) 183

Figura 89 - Aldeia indígena Guarani no Parque Estadual do Jaraguá 187

Figura 90 - Nuvem de palavras a partir dos relatos dos participantes de Perus 187

Figura 91 - Representação dos agentes da Universidade Livre e Colaborativa 188 


\section{LISTA DE MAPAS}

Mapa 1 - Índice de Vulnerabilidade Social Paulista (IPVS) ................................................52

Mapa 2 - Espaços Culturais na cidade de São Paulo ..................................................................54

Mapa 3 - Museus na cidade de São Paulo .............................................................................55

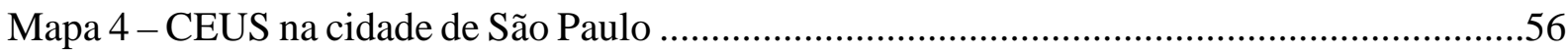

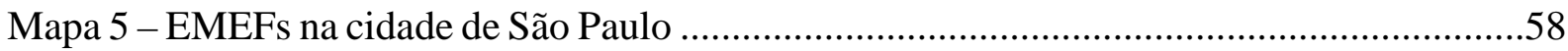

Mapa 6 - Unidades Básicas de Saúde (UBS) na cidade de São Paulo ......................................59

Mapa 7 - Localização dos distritos em que o estudo ocorreu: Perus e Grajaú ..........................110

Mapa 8 - Localização da Subprefeitura de Perus, Sé e Capela do Socorro ..............................111

Mapa 9 - Índice Paulista de Vulnerabilidade Social ..........................................................112

Mapa 10 - Meio físico do município de São Paulo ...................................................................113

Mapa 11 - Lei de Parcelamento, Uso e Ocupação do Solo da Subprefeitura de Capela do

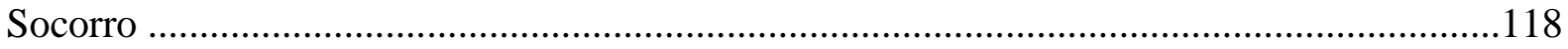

Mapa 12 - Equipamentos de Cultura no Grajaú .............................................................121

Mapa 13 - Equipamentos de Saúde no Grajaú ...............................................................122

Mapa 14 - Rede Pública de Educação no Grajaú .................................................................123

Mapa 15 - Localização dos distritos em que o estudo ocorreu: Perus e Grajaú ........................165

Mapa 16 - Localização da Subprefeitura de Perus, Sé e Capela do Socorro .............................166

Mapa 17 - Índice Paulista de Vulnerabilidade Social ............................................................167

Mapa 18 - Conexão dos terminais Perus e Anhanguera ........................................................168

Mapa 19 - Rede de Estruturação Local .............................................................................170

Mapa 20 - Território de Interesse da Cultura e da Paisagem (TICP Jaraguá-Perus)

\section{LISTA DE TABELAS}

Tabela 1 


\section{SUMÁRIO}

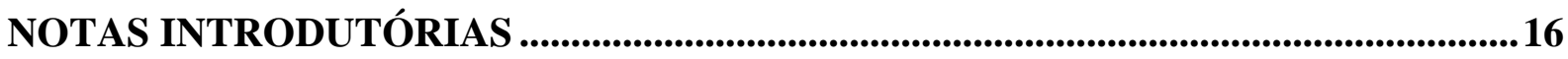

1. TERRITÓRIO: UM CONCEITO EM DISPUTA ............................................21

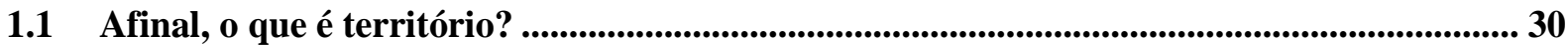

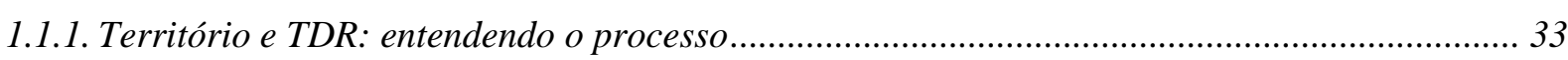

1.2 São Paulo: territórios de resistência ....................................................................................... 42

2. EDUCAÇÃO: O CAMINHO DA ESCOLA AO TERRITÓRIO ...............................61

2.1 Século XX: o movimento de renovação pedagógica e as contribuições da psicologia da aprendizagem para a educação ...........................................................................................................61

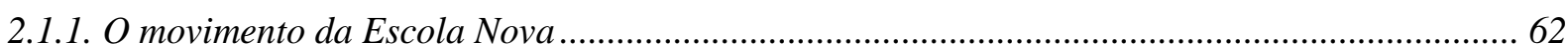

2.1.2. Teoria sociocultural e o processo de formação de conceitos em Vygotsky ................................ 66

2.2. Educação formal, não-formal, popular, comunitária e social....................................................... 74

2.2.1. O conceito de educação formal, não-formal e informal .............................................................. 74

2.2.2. Educação popular, social e comunitária.................................................................................... 80

2.2.3. A crítica ao sistema educacional formal e a emergência de práticas e discursos de educação não-

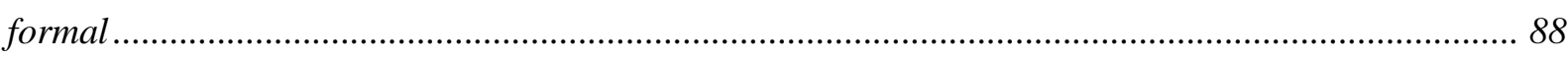

2.3. Para além dos muros da universidade: em busca de uma extensão universitária

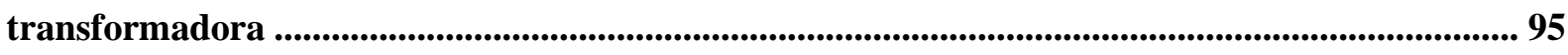

2.4. Caminhando para o século XXI: a cidade como território educativo ..................................... 104

3. TERRITÓRIO E EDUCAÇÃO: A PRÁXIS EDUCATIVA NOS TERRITÓRIOS PERIFÉRICOS DE SÃO PAULO ................................................................................110

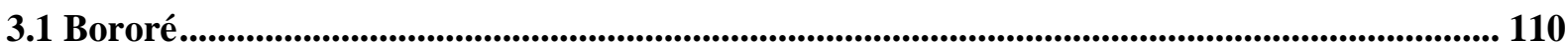

3.2 Ilha do Bororé: uma cidadania em despertar, o exercício pedagógico no território para

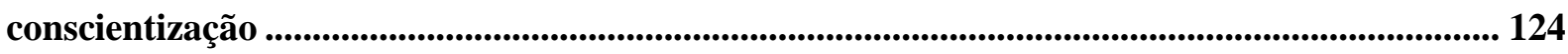

3.2.1 A casa Ecoativa e o ativismo ecocultural: construindo narrativas de um território educador. 132

3.2.2 A escola como lugar de interação sociocultural........................................................................ 141

3.2.3 A extensão universitária e o projeto Bororé ao mundo ............................................................. 145

3.2.4. As práticas educativas no Bororé na ótica da educação freireana ........................................... 157

3.3 Perus .................................................................................................................................................................. 164

3.4 As práticas educativas em Perus: o exercício pedagógico e político da construção coletiva da memória e do conhecimento ..................................................................................................................... 171

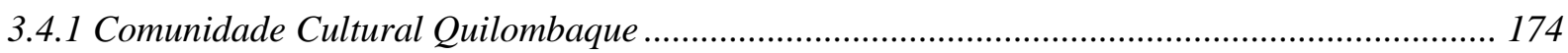

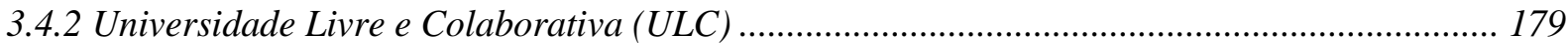

3.4.3. As práticas educativas em Perus na ótica da educação freireana.............................................. 189

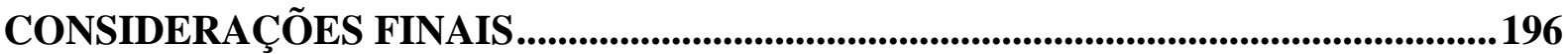


REFERÊNCIAS BIBLIOGRÁFICAS .......................................................................200

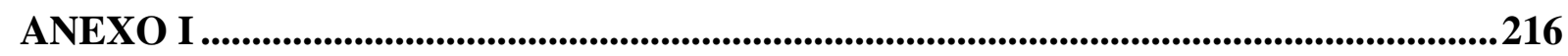

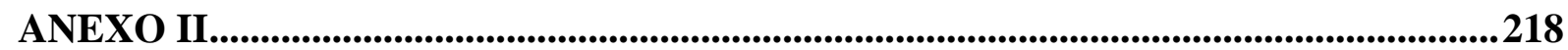

ANEXO III - CERTIFICADO DE DEFESA ...................................................................220 


\section{NOTAS INTRODUTÓRIAS}

O Movimento das Cidades Educadoras ocorreu no início da década de 1990 na Espanha paralelamente a diversas discussões, tratados e declarações mundiais relacionados a se pensar o "futuro" da sociedade do século XXI, que seria agraciada com os avanços tecnológicos e novas perspectivas de sociabilidade, produção e comunicação. Os países latino-americanos haviam se redemocratizado, o Brasil acabava de promulgar a Constituição Cidadã. A consciência de problemas enfrentados nas décadas anteriores parecia ser a mola propulsora a se pensar projetos alternativos de futuro, pautados na construção de uma sociedade global, sustentável, democrática e mais humana no século XXI. No Brasil, as discussões em torno da cidade educadora e território educador estão vinculadas às discussões sobre educação integral e escola cidadã, em vista da consciência crescente da necessidade de territorialização das políticas e das práticas, a partir da percepção da ineficácia do Estado em implementar uma educação de qualidade para todos.

Por outro lado, o contexto global de avanço do neoliberalismo nas cidades também incidiu na qualidade de vida dos cidadãos urbanos, aprofundando a desigualdade social, a violência, o desemprego nas cidades brasileiras. A construção histórica excludente, frequentemente ressaltada por pesquisadoras como Ermínia Maricato (1996), impõe a compreensão da autoconstrução como alternativa possível dentro de um sistema que é ambíguo, desigual e gerador de uma cidade "informal” e ilegal na periferia do capitalismo.

A partir de 1988, o país passa a ter um arcabouço legislativo favorável ao exercício da cidadania pela parcela historicamente excluída dos brasileiros. A redemocratização do país e as conquistas logradas com as lutas urbanas do último quarto do século XX incidiram de forma objetiva e concreta na vida dos novos cidadãos urbanos, ou como denominou Holston (2013) “cidadãos insurgentes”. Ademais, operou também na subjetividade desses grupos como sujeitos de direitos, sujeitos da história (e de sua própria história) capazes de construir projetos voltados a atender as especificidades concretas de seus territórios. Dessa forma, o processo de conscientização política sobre a importância da construção social ampla dos projetos de sociedade se constituiu como uma marca dos territórios de luta e resistência das grandes cidades.

A reelaboração simbólica relacionada aos novos cidadãos urbanos, ou insurgentes, ocorre por meio da mudança da escala do "objeto", ao se olhar de perto a realidade concreta desses territórios e do olhar para esses grupos sociais como sujeitos desses territórios. A 
mudança qualitativa no olhar ocorreu notadamente pelos próprios sujeitos que ressignificaram a estigmatização sofrida devido às condições desiguais que causaram a segregação socioespacial e lançaram novos olhares de "potência” para suas realizações e contribuições na cidade. Desse modo, os sujeitos periféricos (D’ANDREA, 2020) atuam no campo das subjetividades como forma de resistência. É nessa virada qualitativa, aliada a governos populares no início da década de 1990, em São Paulo, e dos anos 2000 no Brasil, que os coletivos urbanos têm tido protagonismo nas expressões relacionadas à construção de novas narrativas sobre seus territórios, notadamente a partir da primeira década do século XXI. As ações culturais possuem um teor estético e político, com uma dimensão educativa que é transversal às suas pautas, em grande parte relacionadas ao direito à cidade (HARVEY, 2014) e ao exercício da cidadania.

Contudo, vale destacar a inegável sofisticação e ressignificação de discursos também em outras dimensões e escalas, como as da produção, do consumo e do capital. Se por um lado houve avanço por meio de resistência e luta em se buscar legitimar "outros modos de fazer” de grupos marginalizados da sociedade, por outro, houve também retrocesso em se induzir a sociedade a formas de controles sutis como a "uberização" e "gameficação" da vida, que aprisionam e conduzem a população a um estilo de vida precário, de modo a alienar e amortecer os impactos da contemporaneidade neoliberal. Essa situação fica clara quando se pensa na metrópole São Paulo e sua multiplicidade de paisagens e territórios: a existência do que convencionou-se chamar de “farialimers”, na linguagem de crítica da juventude engajada, como o território da abundância de tecnologias, oferta de diversos serviços, da cidade “moderna”, em oposição aos territórios periféricos, que a despeito de sua intensa produção cultural, artística e crítica, ainda mantem lutas históricas para obtenção de mínimas condições de qualidade de vida, fruto das contradições construídas socialmente ao longo da história e que promoveram enorme exclusão socioespacial.

A despeito da associação excludente realizada pelo Estado e o mercado, as periferias têm produzido cidade e conhecimento à revelia da “ordem urbanística” hegemônica normativa, com sua própria “ordem urbana” desejada, em seu próprio tempo. Nesse contexto, os processos de conscientização que já estavam em curso, diante de um contexto mais amplo de lutas urbanas e democráticas, ocorreram também por meio de parcerias entre a universidade e coletivos de cultura em territórios periféricos da cidade de São Paulo. Em Perus, distrito da região noroeste de São Paulo, ocorreu um processo colaborativo de construção de conhecimento. Essa parceria ocorreu entre a Comunidade Cultural Quilombaque e de outros agentes locais com a o Núcleo 
de Estudos da Paisagem da Faculdade de Arquitetura e Urbanismo da Universidade de São Paulo (NEP/USP), conformando a Universidade Livre e Colaborativa (ULC), cujo resultado mais concreto consistiu na inclusão do instrumento urbanístico do TICP (Território de Interesse da Cultura e da Paisagem), proposto pelo grupo, no Plano Diretor Estratégico da Cidade de São Paulo, em 2014. A participação na pesquisa “Conceituação e perimetrização de território para um TICP” e da disciplina de pós-graduação sore o TICP em Perus me proporcionou o contato com agentes importantes do território, como o Movimento pela Reapropriação da Fábrica de Perus, o Centro Integrado de Educação de Jovens e Adultos (CIEJA), professores militantes e com a Quilombaque. Tal aproximação também proporcionou conhecer a história de lutas e suas as memórias.

No outro extremo do município, na área rural da zona sul e do Grajaú, onde se localiza o bairro do Bororé, houve também a parceria entre o coletivo ecocultural da Casa Ecoativa, a escola estadual Professor Adrião Bernardes e o Grupo de Estudos de Mapografias Urbanas da Faculdade de Arquitetura e Urbanismo da Universidade de São Paulo (GeMAP/USP). Tal parceria consiste em um trabalho de colaboração entre os três agentes na ativação dos potenciais educativos do território e de construção de projetos territorializados para a comunidade a médio e longo prazo. A minha participação no Grupo de Estudos de Mapografias Urbanas (GeMap) e na extensão universitária no território do Bororé permitiu perceber outra dinâmica territorial, outros tempos e espaços, outros atores e demandas, possibilitando a compreensão da organização coletiva e dos desejos de transformação territorial e social.

É importante destacar que ambos os territórios são denominados de “educadores” por seus agentes, os quais atuam na dimensão da cultura e da educação por meio de práticas criativas e insurgentes. Igualmente, é importante destacar que a minha territorialização nesses dois processos ocorreu por meio da territorialização na universidade, por meio da atuação de professores comprometidos em realizar a função social da universidade pública.

Desse modo, a percepção das questões apresentadas acima, da complexidade das relações de poder que constituem o território urbano de São Paulo, bem como dos discursos que tem crescido na última década no âmbito ativista, como o que abarca a ideia de território educador, levaram-me aos seguintes questionamentos durante a pesquisa: é possível o território ser um agente? E mais, um agente educador? Há uma relação direta entre território e educação? $\mathrm{Na}$ trajetória de pesquisa busquei compreender a relação entre esses dois conceitos, os conteúdos e as práticas que eles implicam. Outras questões também surgiram ao longo do processo, como quais seriam as potencialidades e as limitações de trabalhos como esses 
desenvolvidos em parceria entre a universidade e os “coletivos territorializados” (BASSANI, 2019) uma efetiva transformação social.

Dessa forma, a compreensão da dialética entre educação - no âmbito da formação para cidadania, através da conscientização - e território verifica-se central nesta pesquisa. Vale registrar ainda da importância dada à compreensão sobre como ocorre processo de aprendizagem a partir da consciência dos potenciais educativos do território e da mediação de agentes locais.

Portanto, neste trabalho a problematização sobre o tema ocorre a partir da compreensão política do conceito de território (RAFFESTIN, 1993) e da prática de territorialização da extensão universitária e dos coletivos territorializados. Isto é, por um lado, analisarei a dimensão educativa dos processos de constituição territorial (através da práxis mobilizada pelos conflitos e disputas engendrados); e, por outro, a dimensão territorial das propostas educativas realizadas nos casos estudados. Para isso, será utilizada a concepção de educação popular de Paulo Freire (1981; 1983; 1996; 2018). Ademais, para analisar as práticas pedagógicas no território do Bororé e de Perus será relacionada a abordagem de Vygotsky (2001) sobre o desenvolvimento cognitivo, no sentido de que o aprendizado ocorre através da interação entre linguagem e realidade sociocultural.

É importante destacar o diálogo que busco fazer com o campo da geografia, a partir do conceito de território, bem como da educação, ao intentar compreender sua relação com o território urbano por meio de movimentos educacionais, propostas pedagógicas e práticas. Vale ressaltar que o estudo de como se dá o processo de aprendizagem já foi abordado exaustivamente no campo da psicologia da educação, ocorrendo apenas como uma aproximação neste trabalho que busca compreender práticas educativas. Desse modo, o presente trabalho pretende analisar a relação entre território, educação e formação cidadã no âmbito das práticas realizadas pelos coletivos de cultura e pela extensão universitária no município de São Paulo.

O estudo busca contribuir com a compreensão das práticas existentes nesses territórios, por meio de um olhar teórico e sistematizado, a fim de possibilitar a reflexão sobre a prática da extensão universitária e dos coletivos territorializados. Tal reflexão visa a ampliação das práticas que ocorrem no "extramuros" da universidade, na medida em que deseja contribuir com a reflexão sobre métodos e linguagens utilizados em processos coletivos e colaborativos relacionados ao exercício do direito à cidade e da cidadania. Partilho da visão de que a ampliação de diálogos com os grupos organizados da sociedade civil por meio da extensão 
universitária são processos potentes e positivos, de modo que também se constituem como processos formativos para os universitários e pesquisadores que atuam e buscam uma extensão universitária transformadora, nos princípios defendidos por Paulo Freire (1983). Desse modo, o trabalho pretende compreender os mecanismos de interação entre educação, território e cidadania.

Em Perus, a pesquisa de campo foi pautada pela participação na disciplina de pósgraduação intitulada “Territórios de Interesse da Cultura e da Paisagem”, na Faculdade de Arquitetura e Urbanismo da USP (FAUUSP), no segundo semestre de 2019. Ademais, contou com entrevistas semiestruturadas com atores envolvidos no processo de construção do TICP, por meio da minha participação na pesquisa “Conceituação e perimetrização de território para um TICP”. Já no território do Bororé, a pesquisa de campo, em 2019, pautou-se pela atuação na extensão universitária do GeMAP/USP, "Memória do Bororé - Geografia e Cultura do território”, em colaboração com a Casa Ecoativa e a E. E. Adrião Bernardes. Ocorreram oficinas de cartografia, mapeamentos sobre pontos do território a partir de entrevistas abertas com moradores antigos, professores e alunos da escola.

Desse modo, a estrutura do trabalho está dividida da seguinte maneira: o primeiro capítulo se destinará ao aprofundamento dos conceitos relacionados ao território, os seus múltiplos significados e a importância do conceito para a ciência urbana. Por sua vez, o segundo capítulo será destinado a contextualizar a educação e a sua relação com o território, notadamente de que maneira os discursos pedagógicos passaram a considerar a cidade como território educativo, bem como as diferentes acepções de educação envolvendo o território. Por fim, serão analisadas as práticas realizadas no Bororé e em Perus, buscando compreender a relação entre território, educação e cidadania nesses processos. 


\section{TERRITÓRIO: UM CONCEITO EM DISPUTA}

Essencialmente polissêmico, o termo território é utilizado de maneiras distintas nas diferentes áreas do conhecimento. Dentro do campo da arquitetura e urbanismo, o conceito apresenta também a sua própria mutação ao longo do tempo. Nesta seção serão apresentadas, de forma sintética, as diferentes concepções do termo, bem como a sua evolução histórica no âmbito dos estudos urbanos e territoriais no contexto global e nacional.

Historicamente, no campo da geografia política o termo território foi utilizado para legitimar o poder de domínio do Estado-nação nas conquistas de terra na formação dos “territórios nacionais” (RAFFESTIN, 1993 [1980]; SOUZA, 2020). Nesse contexto, o termo foi e ainda continua sendo utilizado como noção ${ }^{1}$, o que abriu brechas para a naturalização de discursos e práticas hegemônicas e totalitárias. Esse quadro culminou, nos anos 1980, em um esforço crítico para conferir o status de conceito ao termo território por meio de uma leitura crítica, como será exposto mais adiante.

No âmbito do ativismo social ${ }^{2}$ o termo território tem sido amplamente utilizado como noção, geralmente associado a diversas escalas, como a da rua (Território Educativo das Travessias) $^{3}$, a do bairro (Museu Territorial Tekoa Jopo’i) ${ }^{4}$, a de distritos (Território de Interesse da Cultura e da Paisagem - TICP) ${ }^{5}$, a de movimentos educacionais em rede (Territórios Educativos) que veem a cidade como território educativo ${ }^{6}$, a das lutas urbanas e sociais (territórios periféricos) ${ }^{7}$. Tal compreensão de território, mesmo sendo utilizada como noção de espaço de domínio na maioria das situações, tem servido a grupos que resistem e reagem à ordem hegemônica, como os estudos de caso a serem analisados no capítulo 3.

O presente trabalho está inserido no campo dos estudos urbanos e territoriais, no âmbito do urbanismo; contudo, como foi pontuado acima, é importante ressaltar que o termo território é também polissêmico dentre a multiplicidade de disciplinas em que ele tem sido utilizado.

\footnotetext{
${ }^{1}$ Segundo Raffestin (1978 apud RAFFESTIN, 1993, p. 143) “o estatuto de conceito permite uma formalização e/ou quantificação mais precisa do que o estatuto de noção”.

2 Sobre o uso dos conceitos em práticas ativistas na contemporaneidade Cf. BASSANI, J. 2019.

${ }^{3}$ Cf. Portal Aprendiz. Disponível em: https://portal.aprendiz.uol.com.br/2019/10/16/na-virada-educacao-2019cortejo-celebra-parceria-entre-escolas-centro-de-sao-paulo/ Acesso em: 10 nov 2020.

${ }^{4}$ Cf. Portal Aprendiz. Disponível em: https://portal.aprendiz.uol.com.br/2018/12/19/museu-territorial-transformabairro-perus-em-um-territorio-educativo/. Acesso em: 10 nov 2020.

5 Cf. artigos 314 ao 316 no Plano Diretor Estratégico de São Paulo (2014). Disponível em: $<$ https://gestaourbana.prefeitura.sp.gov.br/wp-content/uploads/2015/01/Plano-Diretor-Estrat\%C3\%A9gico-Lein\%C2\%BA-16.050-de-31-de-julho-de-2014-Texto-da-lei-ilustrado.pdf>. Acesso em: 10 nov 2020.

${ }^{6}$ Cf. Portal Aprendiz. Disponível em: < https://portal.aprendiz.uol.com.br/2020/01/24/encontro-de-territorioseducativos-da-cidade-sp-defende-escola-como-espaco-de-producao-territorial/>. Acesso em: 10 nov 2020.

${ }^{7}$ Cf. Periferia em Movimento. Disponível em: http://periferiaemmovimento.com.br/. Acesso em: 10 nov 2020.
} 
Desse modo, exponho algumas definições a partir de diferentes áreas do conhecimento, conforme apresentadas por Rogério Haesbaert (2019). Na Geografia, ciência que estuda as interações entre a natureza e a sociedade, território é tratado de forma multidimensional, em estreita relação com sua materialidade; na Ciência Política o conceito é formulado a partir da dimensão do poder (dimensão política) vinculada ao Estado; na Economia o conceito de espaço tem centralidade em detrimento do conceito de território no tratamento de questões relacionadas à base da produção ou à localização; na Antropologia o conceito é tratado em sua dimensão simbólico-cultural, notadamente no estudo de comunidades tradicionais e seus territórios; na Sociologia o território é estudado para a compreensão de como ele influencia as relações sociais; por fim, na Psicologia o debate é transportado para a escala do indivíduo, buscando compreender questões relacionadas à construção da subjetividade (HAESBAERT, 2019).

Figura 1 - Território na Geografia: Representação gráfica da Represa Billings, no Grajaú, como o território da navegação e da arte

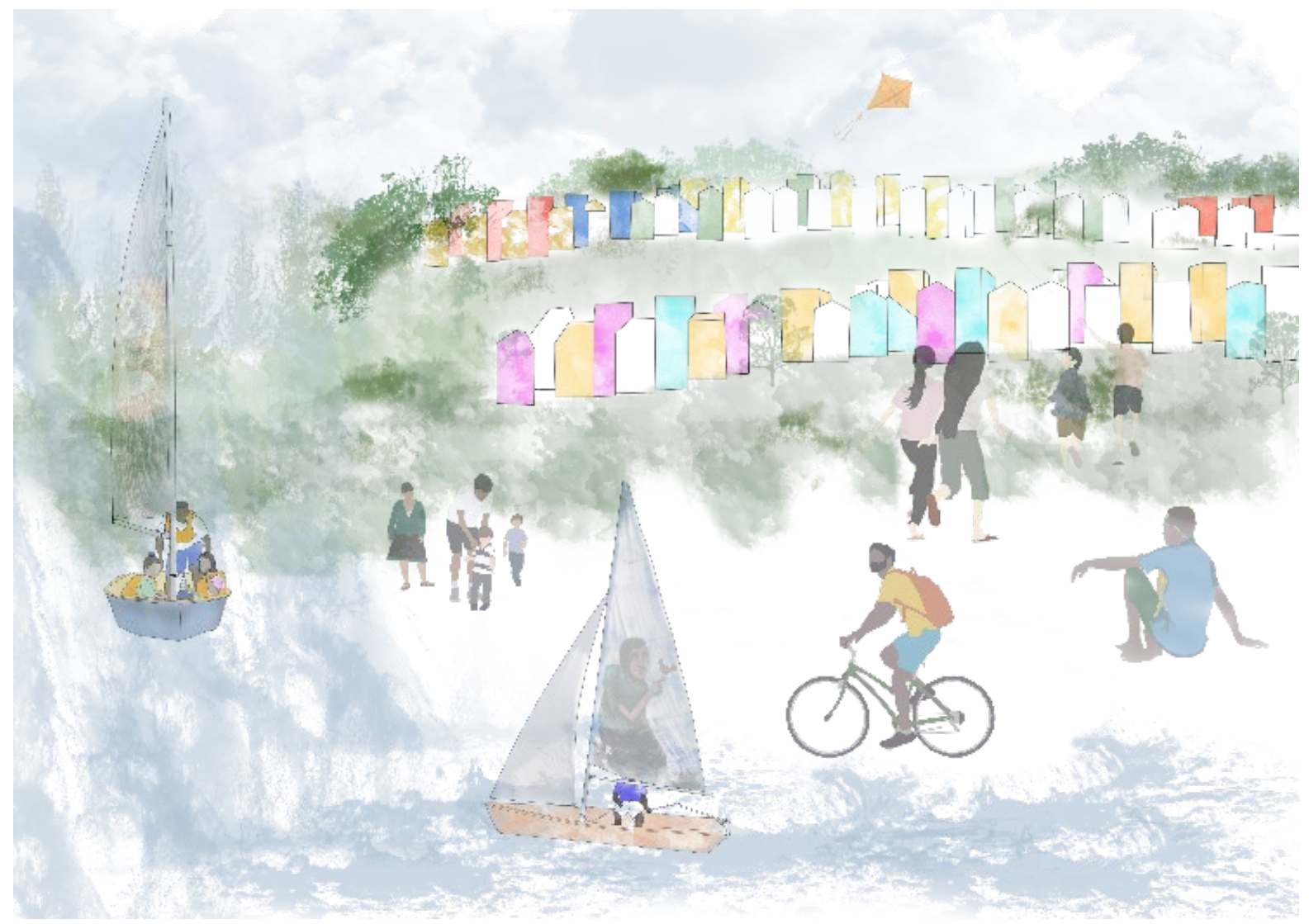

Fonte: idealização da autora, elaboração Camilla Ortega. 
Figura 2 - Território na Ciência Política: Representação gráfica do “território nacional”

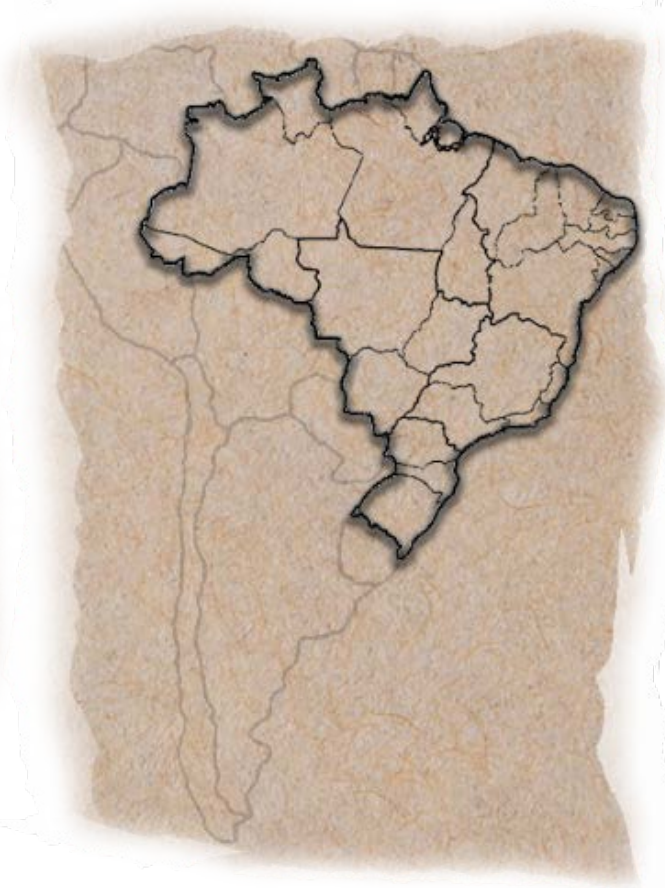

Fonte: idealização da autora, elaboração Camilla Ortega.

Figura 3 - Território na Economia: representação dos tempos e espaços do capital industrial e financeiro

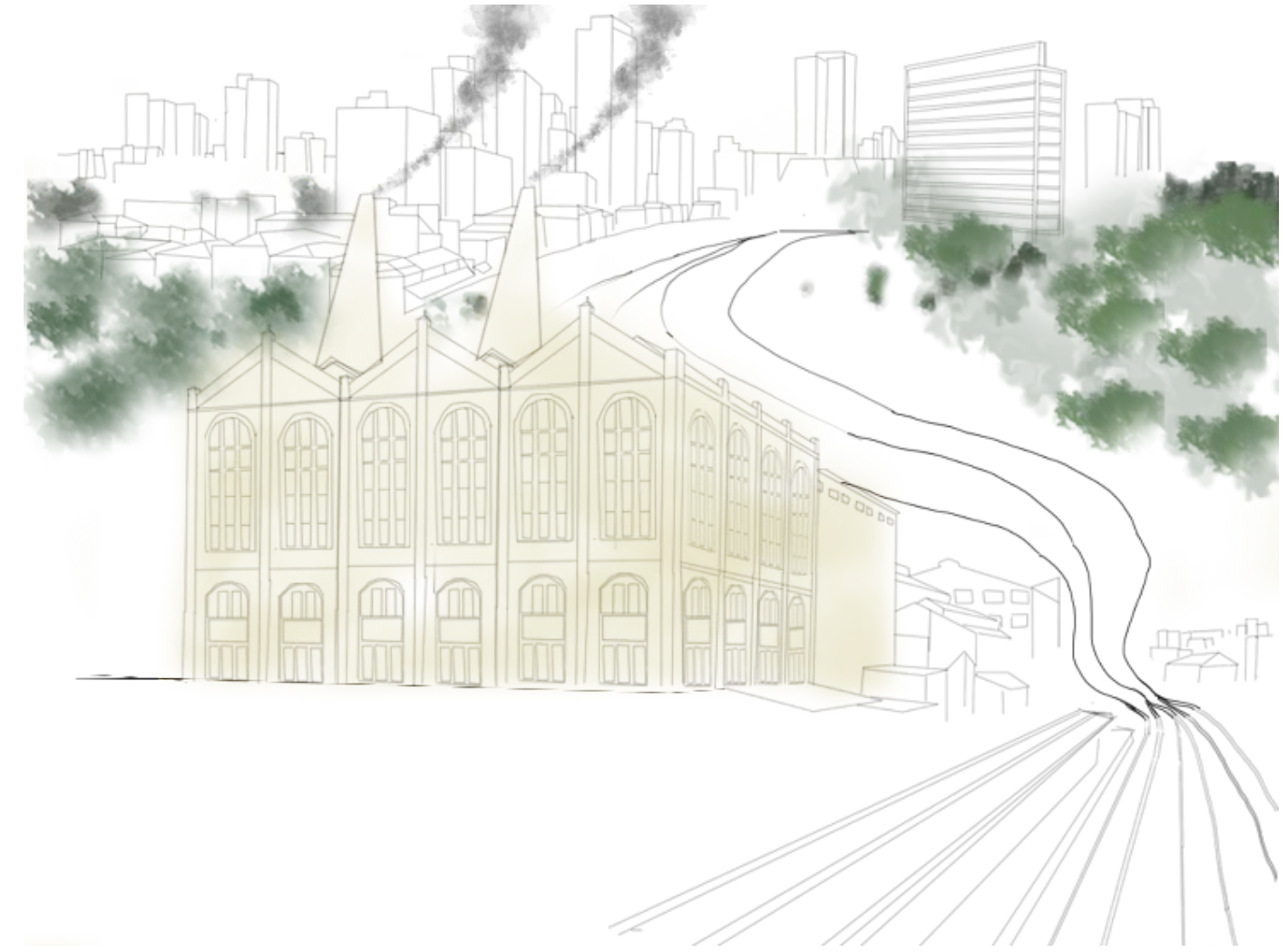

Fonte: idealização da autora, elaboração Camilla Ortega. 
Figura 4 - Território na Antropologia: representação de um território indígena.

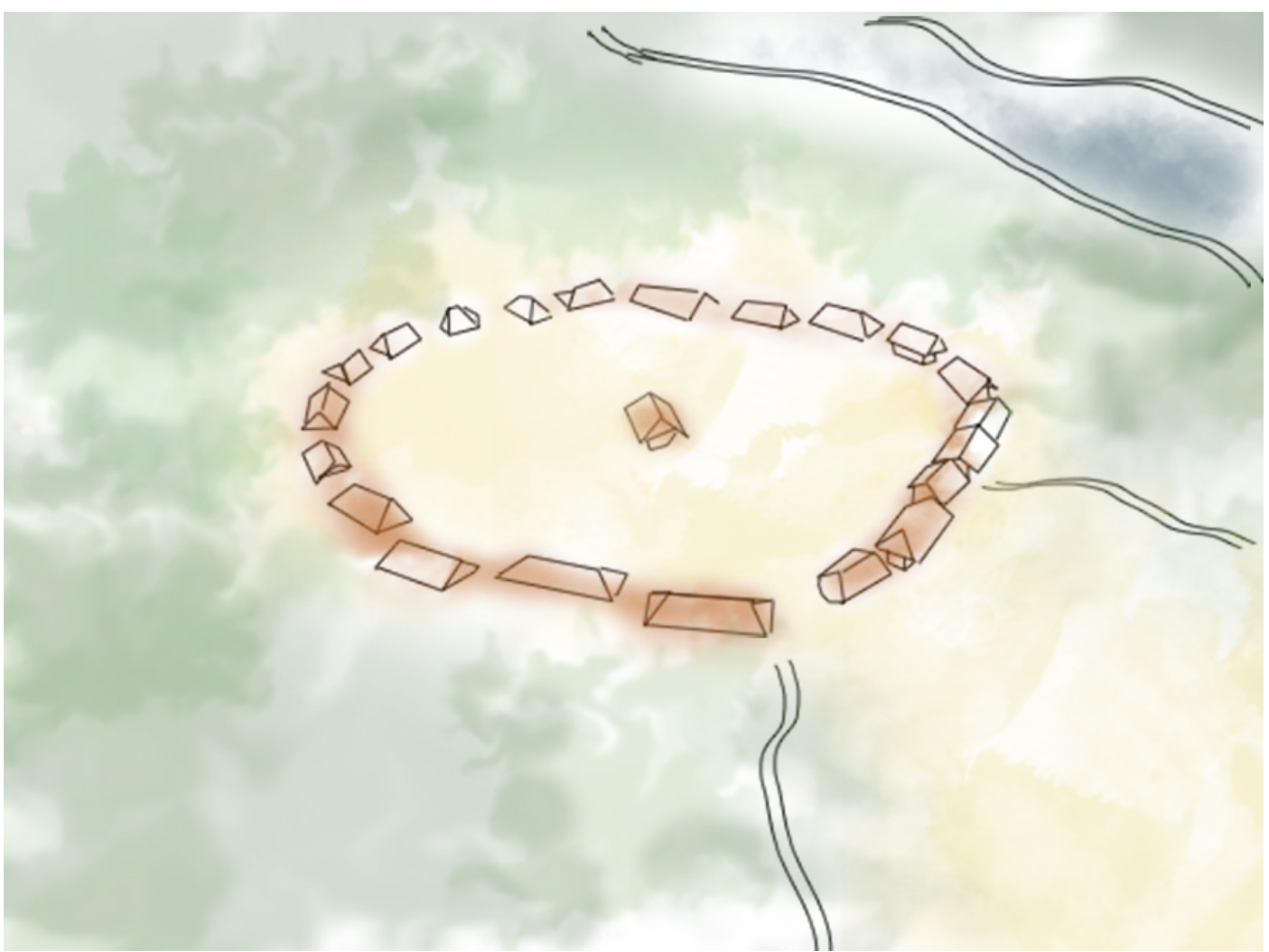

Fonte: idealização da autora, elaboração Camilla Ortega.

Figura 5 - Território na Sociologia: representação da territorialização de práticas políticas - "território do ativismo"

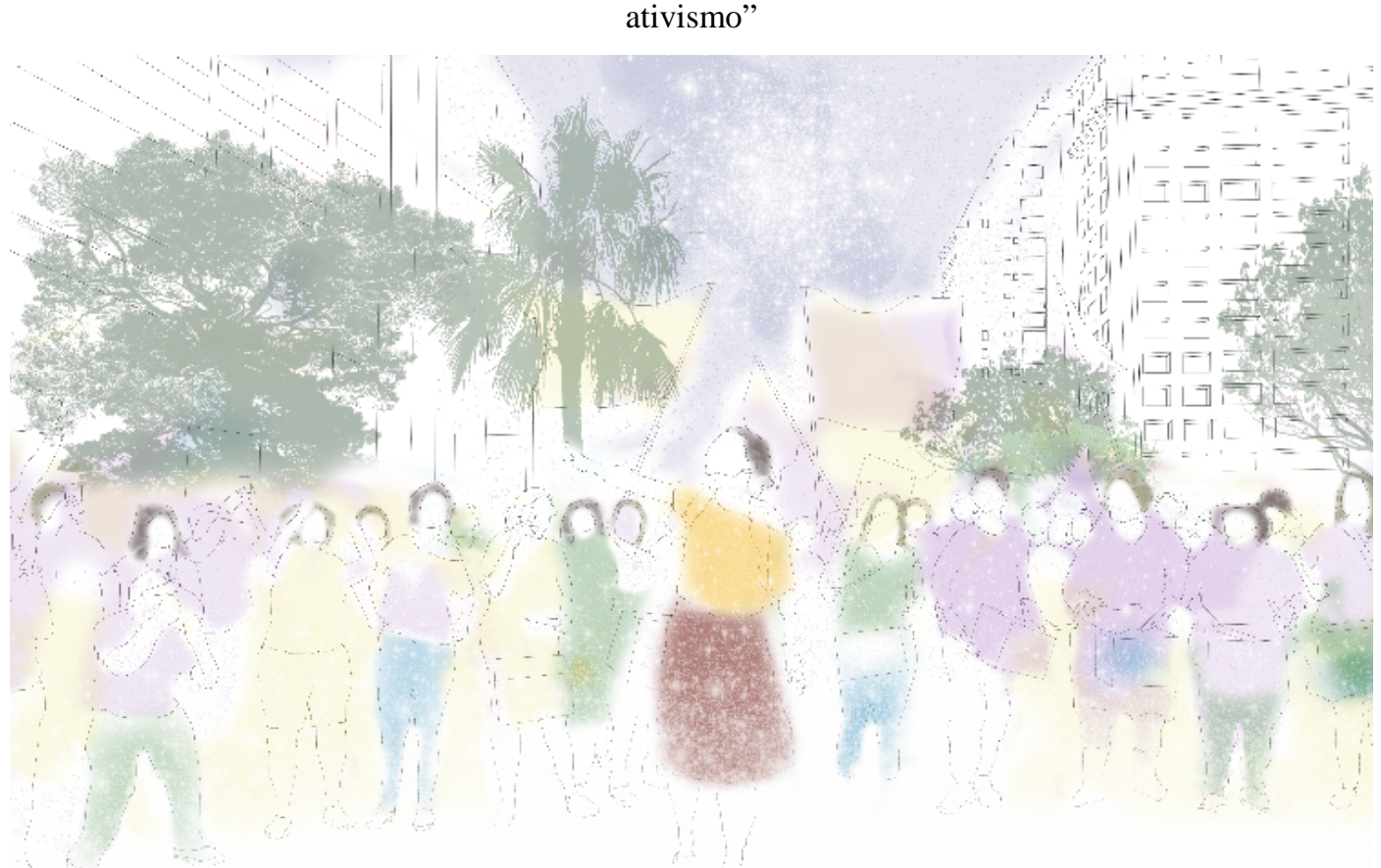

Fonte: idealização da autora, elaboração Camilla Ortega. 


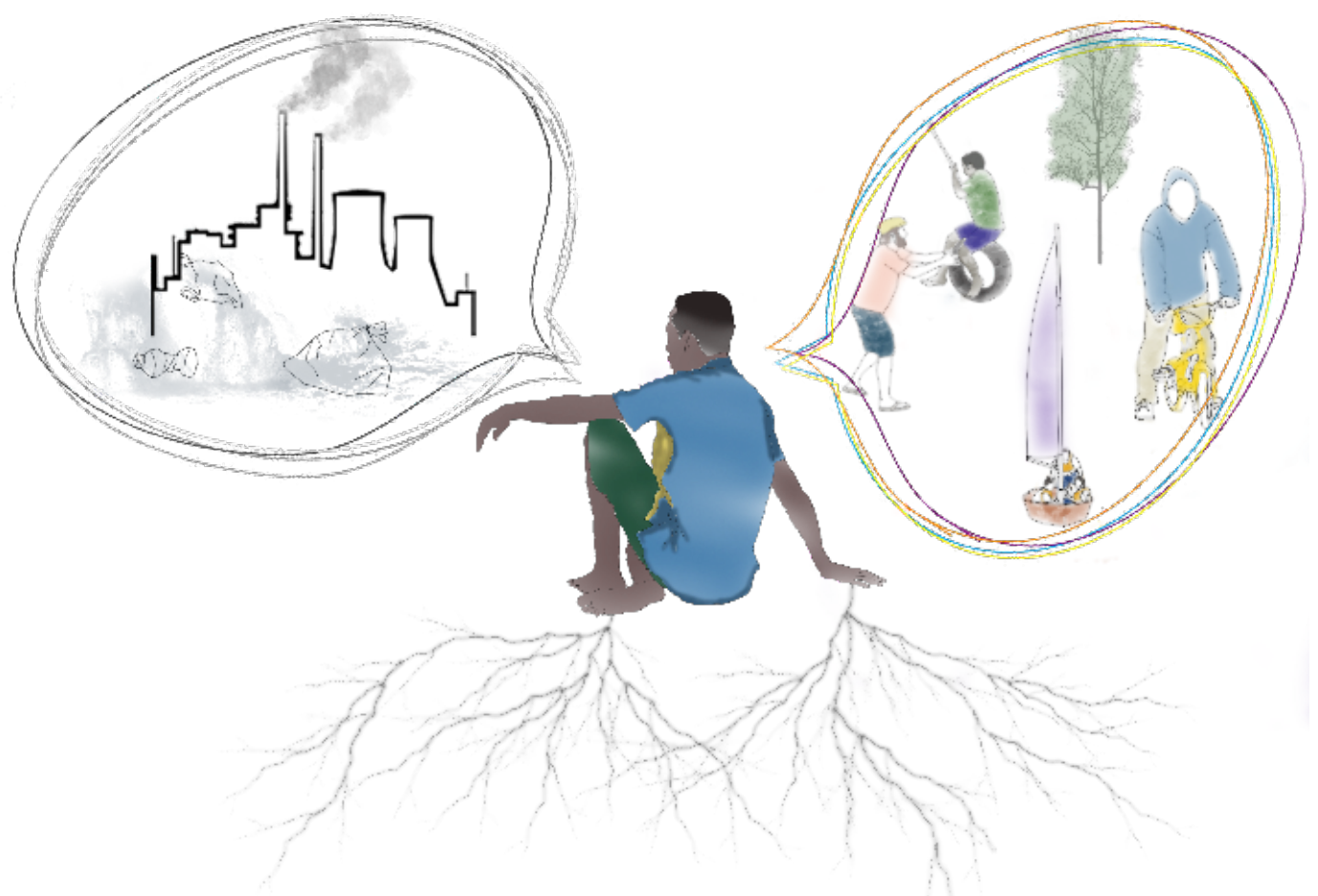

Fonte: idealização da autora, elaboração Camilla Ortega.

Segundo o urbanista Jorge Bassani (2019), o campo da arquitetura e do urbanismo elaborou novas formulações e interpretações sobre o urbano a partir da década de 1960, as quais romperam com a tradição do modernismo funcionalista, em que o objeto (cidade) era visto como um “espaço projetável”, partindo para uma abordagem complexa sobre a multiplicidade dos vetores que incidiam sobre as transformações urbanas, em que a subjetividade e a experiência do sujeito se associaram à escala do lugar (BASSANI, 2019). Bassani (2019, pp. 59-60) assinala, todavia, que apesar das contribuições teórico-analíticas do lugar no campo da arquitetura e do urbanismo, elas se mostraram incapazes de operar na compreensão e crítica sobre o urbano no bojo das transformações macroescalares da "cidade neoliberal", intensificadas a partir da década de 1990, sob o código do consumo. De acordo com Meyer (2006 apud BASSANI, 2019), os instrumentos de análise no campo do urbanismo, frente às transformações urbanas intensificadas a partir de meados do século XX, tornaram-se incapazes de lançar uma compreensão que as abarcasse de forma satisfatória, o que aproximou os urbanistas do termo território proveniente de teóricos do campo da geografia, notadamente da 
geografia urbana. Segundo Bassani (2019, p. 61): “[...] o conceito de território é aplicado ao urbanismo como ferramenta interpretativa destes processos dinâmicos e reativos às intervenções promovidas por suas atividades”.

É importante destacar que a incorporação conceitual de território no campo do urbanismo possibilitou novas abordagens teórico-analíticas sobre os processos urbanos contemporâneos para a disciplina; por outro lado, os avanços da prática do urbanismo influenciado pelo neoliberalismo substanciou "contra-discursos” daqueles que não projetam a "cidade-neoliberal” ${ }^{8}$, mas a vivem e a disputam, sobretudo coletivos urbanos e ativistas (BASSANI, 2019).

Essa epifania do conceito de território e o seu uso no ativismo social contemporâneo e nas ciências que tratam do urbano está circunscrita em um contexto mais amplo das ciências como um todo, verificado na década de 1960: o rompimento com os paradigmas da ciência moderna vigentes até então. O século XX deixou profundas marcas na humanidade, provenientes do avanço técnico-científico conquistado, não só pela utilização para fins bélicos (duas grandes guerras), mas também com a difusão e ampliação dos meios de comunicação e informação (da globalização) e, espetacularmente, do consumo. Segundo Michel Thiollent $(1998)^{9}$, as contestações da época ${ }^{10}$ não se limitavam apenas ao campo político e ideológico, mas eram, também, de ordem psicológica e educacional. Para o autor, as rupturas consistiram na contestação do estruturalismo nas ciências sociais e a emergência das questões voltadas ao sujeito, com o surgimento de estudos no campo da fenomenologia, psicanálise e teoria crítica. Wallerstein [s.d.] identifica que os efeitos imediatos dos levantes de 1968 foram a legitimação,

\footnotetext{
${ }^{8}$ A cidade neoliberal pode ser considera um produto desse contexto pós-moderno. Segundo Harvey (2005) as transformações macroeconômicas e políticas do pós-guerra até 1970, e notadamente a partir de 1980, marcaram a passagem do modo de acumulação capitalista fordista, de bases doutrinárias do keynesianismo e governança urbana administrativa para o modo de acumulação flexível com bases neoliberais de livre mercado e governança urbana empreendedora. Essa nova governança urbana gerou novos padrões de desenvolvimento urbano pautados no desenvolvimento econômico, através de intervenções pontuais na cidade, pelas Parcerias Público-Privada (PPP), com a intensificação da gentrificação e o design urbano de luxo. As políticas urbanas mudaram seu perfil para o empreendedorismo urbano na medida em que o Estado atuou como patrocinador dos gastos pesados em infraestrutura para a iniciativa privada entrar com os investimentos e obter os lucros através das PPP's, de um lado, em detrimento das necessidades locais dos mais vulneráveis, do outro. Com objetivo de atrair investimentos e expor a cidade na vitrine mundial dos negócios, o processo de urbanização sob o empreendedorismo urbano voltou a face ao capital global e as costas à própria população, causando a ampliação do empobrecimento urbano e desigualdade social. Cf. HARVEY, 2005, pp. 163-190.

${ }^{9}$ Cf. THIOLLENT, 1998.

${ }^{10}$ Nesse período, o mundo todo se encontrava em clima revolucionário, a Ásia experimentava diversos conflitos e transformações como a Revolução Cultural Chinesa e a Guerra do Vietnã, enquanto a América Latina se ocupava com conflitos relacionados ao endurecimento político das ditaduras em curso. Os ecos do "desenvolvimentismo" começavam a ruir, a irrelevância dos valores relacionados à vida em favor da produção e consumo em massa começavam a descortinar os efeitos nefastos causados ao meio ambiente e ao ser humano.
} 
de um lado, das questões relacionados à raça e sexo ${ }^{11}$, e de outro uma coalização de forças de centro e direita na economia-mundo, com o abandono do desenvolvimentismo em substituição pela globalização, cuja abertura dos mercados internacionalmente configurou as políticas do neoliberalismo a partir dos anos 1970.

Também na década de 1960 verificou-se uma renovação teórico-conceitual do território com a incorporação da dimensão política, sobretudo diante da notória influência de Michel Foucault $^{12}$ e Henri Lefébvre ${ }^{13}$, os quais aparecem fortemente na concepção de uma nova geografia do poder, em Claude Raffestin; Gilles Delleuze e Félix Guattari, que elaboraram os conceitos de desterritorialização e reterritorialização (TDR); e Michel de Certeau, com a abordagem sobre o cotidiano e as táticas de resistência ao poder (BASSANI, 2019).

A renovação da geografia é resultado desse contexto engendrado nos anos 1960, com a reformulação dos conceitos de território, paisagem e espaço geográfico, saindo de uma abordagem pragmática, quantitativa e positivista para abordagens histórico-críticas marxistas e não marxistas, com enfoque nos processos sociais e naturais (SAQUET, 2015). Da mesma forma, a dimensão política do conceito de território vinculou-se à questão do poder, a partir da influência da filosofia elaborada na época. Na visão de Quaini (2009 apud SAQUET, 2015) a abordagem pautada no materialismo histórico compreende o homem como sujeito histórico, que constrói o território a partir da relação capital-trabalho. De acordo com Saquet (2015), as leituras passam a ter uma abordagem territorial integrada à luta de classes na compreensão dos processos capitalistas de produção; a partir dos anos 1980, a pauta ambiental ganha destaque na academia e com o chegar da década de 1990 destacam-se os temas relacionados às redes, à comunicação, à industrialização, à urbanização e aos movimentos sociais. No Brasil a renovação da geografia se deu por geógrafos que privilegiaram o conceito de espaço geográfico, como Milton Santos, Berta Becker, Ruy Moreira (SAQUET, 2015).

É importante destacar o geógrafo e professor brasileiro Milton Santos por sua contribuição também no período, com a publicação de Por uma Geografia Nova, em 1978, considerado um clássico da teoria geográfica. Nesta obra, o autor ainda não dá enfoque ao conceito de território, mas sim ao de espaço. Preocupado em compreender a realidade brasileira

\footnotetext{
11 Ver também MIGNOLO, 2004, pp. 667-709.

12 "Foucault empreende uma obra na qual expõe o discurso e seus procedimentos, dispositivos e enunciados como instrumentalização e representação do poder, da presença do Estado e do Capital às micropolíticas das relações interpessoais, passando pela análise das instituições na reprodução dos discursos” (BASSANI, 2019, p. 32).

13 “O cerne da revolução imaginada por Marx e Engels consiste da tomada dos meios de produção pelo proletariado, o direito à cidade de Lefebvre conceitua uma condição (inerente ao seu entendimento de urbano) de posse da cidade como potencial revolucionário” (BASSANI, 2019, p. 26).
} 
frente às transformações produtivas e sociais do mundo globalizado, há em sua obra a prevalência do objeto de grande escala (nacional/global) e suas relações (MORAES, 2013). Segundo Antônio Carlos Moraes (2013) ${ }^{14}$, o conceito de território inicialmente foi utilizado na obra de Milton Santos para designar a demarcação político-administrativa na escala nacional e, posteriormente, é compreendido como espaço de circulação e base material dos fluxos entre as cidades e redes urbanas que estruturam o território nacional, associado à base material para dominação econômica dos recursos e indivíduos. O autor assinala que com a incorporação mais densa das relações sociais e a dimensão política na teorização de Milton Santos, o território passa a ter maior centralidade em sua obra e a ser formulado como um conceito.

A despeito do presente trabalho privilegiar a concepção de território adotada por Raffestin, que será abordada posteriormente, vale destacar, ainda, três obras de Milton Santos no que diz respeito ao tema: a primeira, O espaço do cidadão (1987), publicada no contexto de formulação da nova constituição e redemocratização do país. Segundo Moraes (2013), é o primeiro livro em que o território aparece com destaque na argumentação do autor e é colocado com ênfase na dimensão política, do exercício do poder. A proposta de um novo modelo cívico tem a cultura e o território como centrais, sob a gestão territorial equilibrada de bens e serviços para o atendimento de toda a coletividade, conferindo à cidadania uma abordagem geográfica ao colocar a questão territorial como central para alcança-la de forma plena (MORAES, 2013, p. 60). Essa abordagem de Milton Santos tem ressonância com as principais pautas de movimentos sociais e coletivos urbanos: o direito à cidade ${ }^{15}$ (e à cidadania). Neste sentido, as palavras de Milton Santos:

Cada homem vale pelo lugar onde está [grifo nosso]: o seu valor como produtor, consumidor, cidadão depende de sua localização no território. Seu valor vai mudando, incessantemente, para melhor ou para pior, em função das diferenças de acessibilidade (tempo, frequência, preço), independentes de sua própria condição. Pessoas com as

\footnotetext{
14 De acordo com Moraes (2013, p. 45), o conceito de território manteve-se secundário e pouco explorado na teorização de Milton Santos até o final da década de 1970, quando foi publicado o livro Por uma Geografia Nova (1978), cuja centralidade do objeto de análise geográfica passa a ser, explicitamente, a categoria "espaço” e, de modo secundário, inicia-se uma discussão relacionada à dimensão política junto ao conceito de "território", notadamente quando tratadas as discussões acerca a soberania e da atuação do Estado, não mais apenas associado à demarcação administrativa de um país. Cf. MORAES, 2013.

${ }^{15}$ Aqui tratado a partir da elaboração de David Harvey que considera a cidade como o espaço onde reivindicações por mudanças sociais e políticas vem à tona constantemente, reforçando a ideia de direito à cidade através da participação política da sociedade ao exigir o uso coletivo dos espaços públicos. O geógrafo entende o direito à cidade como um direito exercido pela coletividade ao incidir sobre o processo de urbanização (HARVEY, 2014, p. 28). Cf. HARVEY, David. Cidades Rebeldes: do direito à cidade à revolução urbana; tradução Jeferson Camargo. - São Paulo: Martins Fontes, 2014.
} 
mesmas virtualidades, a mesma formação, até mesmo o mesmo salário têm valor diferente segundo o lugar em que vivem: as oportunidades não são as mesmas. Por isso, a possibilidade de ser mais, ou menos, cidadão depende, em larga proporção, do ponto do território onde se está. Enquanto um lugar vem a ser condição de sua pobreza, um outro lugar poderia, no mesmo momento histórico, facilitar o acesso àqueles bens e serviços que lhe são teoricamente devidos, mas que, de fato, lhe faltam

(SANTOS, 2014 [1987], p. 107).

A segunda obra é um artigo intitulado "O retorno do território"16, difundida no âmbito acadêmico como um momento em que Milton Santos "privilegia” o conceito de território em sua obra. Nesta formulação, Santos concebe o território como um híbrido, ou seja: ao mesmo tempo em que é a base material para a vida humana, seu uso e significação mudam de acordo com o tempo -, portanto, seu significado deve ser constantemente revisado. Segundo Moraes (2013), tal formulação confere um significado diferente da adotada por Santos ao longo de sua obra, em grande parte relacionada ao Estado-nação e à escala nacional; nessa nova perspectiva, o geógrafo assume a relevância da escala local ${ }^{17}$ e suas relações como fator de resistência ao cenário da globalização.

A terceira obra se destaca pela sua difusão para além do campo da geografia, a partir de urbanistas e educadores que, não por acaso, defendem o “chão da escola” como prática desalienante, em oposição ao ensino tradicional conteudista. Trata-se da obra publicada nos anos 2000, "Por uma outra globalização: do pensamento único à consciência universal”. Segundo Moraes (2013), o conceito de território, que aparece como "território usado", traz uma noção de maior concretude e menor abstração ao adjetivar o território como algo usado, praticado, uma base material em que as relações sociais acontecem, em que o território não é apenas uma base empregada de infraestrutura, mas reflete uma identidade, e que a partir dessa relação local se criam as "contra-racionalidades" ${ }^{18}$ frente aos processos de reprodução do capital globalizado.

\footnotetext{
${ }^{16}$ In. SANTOS, M.; SOUZA, M. A.; SILVEIRA, M. L. (orgs.), 1998 [1994].

${ }^{17}$ Moraes chama a atenção por Foucault e Raffestin não terem sido citados na bibliografia de Milton Santos, visto que a escala dos “micropoderes”, do local em oposição à escala do Estado foram fortemente inspiradas por esses autores, o primeiro na filosofia e o segundo na geografia.

18 “Tem-se então o universo das 'contra-racionalidades, isto é, formas de convivência e de regulação criadas a partir do próprio território’. Enfim, na sua concepção, o território tanto quanto o lugar são esquizofrênicos porque, de um lado acolhem os vetores da globalização... [e] neles se produz uma contraordem” (SANTOS, 2000, pp. 110; 114 apud MORAES, 2013, p. 103).
} 
O território é o chão e mais a população, isto é, uma identidade, o fato e o sentimento de pertencer aquilo que nos pertence. O território é a base do trabalho, da residência, das trocas materiais e espirituais e da vida, sobre as quais ele influi. Quando se fala em território deve-se pois, logo, entender que se está falando em território usado, utilizado por uma dada população... A ideia de tribo, povo, nação e, depois, de Estado nacional decorre dessa relação tornada profunda

(SANTOS, 2000, p. 97 apud MORAES, 2013, p. 101 - grifo nosso).

Com essa breve introdução busquei trazer um panorama sobre o contexto de ruptura nas ciências que tratam do urbano, notadamente no último quarto do século XX. Apresentado o contexto histórico em que a formulação conceitual de território está inserida, trago na próxima seção a conceituação adotada para este trabalho, a partir da obra de Claude Raffestin, cujos aspectos da linguagem, do trabalho e do poder dão a tônica para sua interpretação.

\subsection{Afinal, o que é território?}

A geografia política clássica fundada por Friedrich Ratzel em 1897, na Alemanha, tinha como problemática central as questões relacionadas ao Estado, sendo ele também visto como a única fonte de poder, sob uma concepção unidimensional. Essa geografia política do Estado, como denominou Raffestin, fundou uma concepção “coisificada”, ou "naturalizada” de território, como se fosse apenas uma porção da superfície terrestre, escondendo uma questão ideológica que remete à conquista e à dominação do espaço geográfico pela ação do Estado-

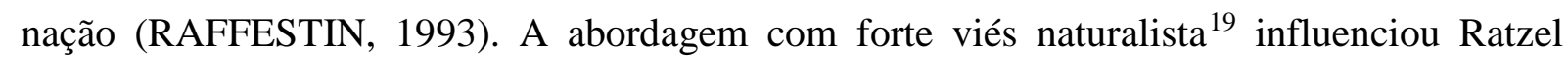
quanto à naturalização do Estado com o solo, e configurou uma espécie de determinismo político (RAFFESTIN, 1993); tal abordagem corroborou para um discurso e um Estado totalitário. Segundo Raffestin, a problemática da geografia política do Estado era morfofuncional e a linguagem utilizada na representação geográfica do real também se dava por códigos que mascaravam outras escalas e sentidos que a não a nacional e a do Estado.

A linguagem na geografia política do Estado, através da utilização de "mecanismos de codificação da geoestrutura” (RAFFESTIN, 1993, p. 28), justificou seu exercício do poder, do ponto de vista de três elementos fundamentais: território (pela unidade territorial), população (a partir de sua homogeneidade) e recursos (através da autoridade e soberania na gestão e

\footnotetext{
${ }^{19}$ A abordagem liga fortemente o homem com o meio, de modo determinista.
} 
administração). Os códigos da geografia do Estado $^{20}$ eram (e ainda são) utilizados com ênfase na representação geométrica da morfologia territorial, como as montanhas, os rios, os tipos de solo, relevo, e a crítica consiste justamente no fato de mascararem a dimensão do espaço vivido, tendo sido utilizados amplamente de forma estratégica e militar, como um território concebido (RAFFESTIN, 1993). Raffestin assinalou que a cartografia moderna e os códigos foram empregados de forma a naturalizar relações dissimétricas e facilitar o exercício do poder do Estado, através do qual a "potência” e a "imagem da potência” poderiam ser alcançadas por uma estratégia territorial (RAFFESTIN, 1993).

Em 1980, inserido no contexto de renovação teórico-conceitual apresentado anteriormente, Claude Raffestin publica na França uma obra seminal ${ }^{21}$ que propõe uma nova abordagem para a geografia política, sob uma problemática relacional, em que o poder ${ }^{22}$ é tido como cerne das relações sociais. Tal proposição se fundamenta na crítica central à geografia política clássica fundada por Friedrich Ratzel.

A compreensão multidimensional e relacional da proposta de geografia política de Raffestin busca o enfoque da pluralidade do poder proveniente de outros sujeitos, como a população e não somente do Estado, na constituição territorial. O diálogo com a abordagem marxista se evidencia pela categoria do trabalho (através da territorialidade) ao configurar as relações - que são sempre de poder - e, consequentemente, o território. Além disso, o autor se apoia na linguística para tratar das questões relacionadas à comunicação, a qual é realizada por meio de trocas de energia e informação entre os “atores” em suas relações - simétricas ou dissimétricas.

[...] a gente falou: "olha, o território ele vai ali, ele chega até a aldeia, mas por conta do significado, não por conta da parte física” e os caras não conseguem pensar, ou não tinham coragem, de pensar alguma coisa que acabasse integrando duas subprefeituras, três distritos, basicamente, mas isso quebrava, isso obrigava a subprefeitura a ter um planejamento conjunto e eles nem queriam saber disso.

(PARTICIPANTE 1, entrevista concedida a Analu Garcia e Diego Fernandes, 2019)

\footnotetext{
${ }^{20}$ Os códigos ali tratados possuem uma dimensão sintática e morfológica (dimensão, forma, posição) e semântica (de sentido). São outros aspectos da linguagem da geografia política do Estado as core areas, as capitais e as fronteiras, determinações relacionadas à forma e a função do espaço geográfico que, por vezes, mascaram as relações de poder que as constituíram ao naturalizá-las. A core area é a “célula primitiva” que teria originado um Estado, pode se referir a uma dimensão espacial e/ou temporal. Cf. RAFFESTIN (1993).

${ }^{21}$ Cf. RAFFESTIN, 1993.

${ }^{22}$ Raffestin se fundamenta em Michel Foucault para tratar do poder sob uma visão multidimensional e imanente às relações sociais, ele não existe somente na esfera de ação do Estado, mas em todos os lugares e relações, extrapola para uma diversidade de atores sociais.
} 
O trecho acima, extraído de uma das entrevistas realizadas durante esta pesquisa, ilustra algumas das questões levantadas na obra de Raffestin: os aspectos constitutivos do território (urbano) como as fronteiras, as localizações, as redes, os códigos e as relações sociais - que, na visão do autor, são sempre revestidas de poder.

É importante destacar a abordagem conceitual que Raffestin dá ao território como um produto das relações sociais sobre o espaço ${ }^{23}$. O espaço, segundo o autor é um suporte, um recurso e um trunfo; tem um caráter geométrico - no que diz respeito às distâncias, às propriedades - cuja representação do real se dá através de relações de equivalências escalares; e contém duas dimensões: plano de expressão, que é o espaço “dado”; e o plano de conteúdo, que são os significados concebidos pelos atores sociais a partir do espaço dado (espaço “inventado”). O mesmo ocorre com o tempo: o tempo real (“dado”) é o tempo astronômico; o tempo relativo (“inventado”) é o “tempo social da ação” (RAFFESTIN, 1993, pp. 48-49).

Em vista disso, o território é posterior ao espaço: “o território se forma a partir do espaço, é o resultado de uma ação conduzida por um ator sintagmático (ator que realiza um programa). Ao se apropriar de um espaço, concreta ou abstratamente (por exemplo pela representação), o ator 'territorializa’ o espaço” (RAFFESTIN, 1993 [1980], p. 143). Desse modo, o processo de constituição territorial é um produto das interações entre o espaço, a população, o trabalho (e o poder, que se constitui como um campo de força invisível que conforma as relações entre aqueles elementos). O território “é também um produto ‘consumido”” (RAFFESTIN, 1993, p. 8) por quem não o produziu, mas o usufrui como um "meio". Neste sentido:

Então pensa no desenvolvimento territorial, então é essa perspectiva de investimento e de descentralização desse orçamento, então o coletivo pega não é só na questão cultural mas sim tem a parte (...) as costureiras, tem né, o cenário... Então já é uma economia gerada ali para nossa região... Então a nossa ação com o museu também é nessa perspectiva de desenvolvimento sustentável local... tirar recurso dentro do bairro e não o bairro saí do seu território e ir pro Centro para gerar renda e essa renda lá, tem que trazer dinheiro para desenvolver o nosso território.

(PARTICIPANTE 10, entrevista concedida a Analu Garcia, 2020)

\footnotetext{
${ }^{23}$ A abordagem lefebvriana de espaço (concebido, vivido e percebido) influencia a concepção de território proposta por Raffestin. Nesse sentido, a cidade e a vida cotidiana conformam o território urbano.
} 
O trecho ilustra a abordagem proposta por Raffestin: o poder que emerge vem da população; quando ela percebe o, ou percebe-se no, sistema territorial (aqui - nosso bairro; e lá - centro) ela decodifica a linguagem do poder do Estado e utiliza os trunfos (recursos) em projetos territoriais em seu favor, buscando acionar novas territorialidades que não reproduzam a dissimetria “dada” e naturalizada historicamente na sociedade, neste caso, brasileira.

A noção de territorialidade teve início com os naturalistas e, de modo geral, seu significado nessa abordagem consiste no comportamento dos animais na defesa ou na dominação de um território. A transferência dessa noção de territorialidade animal para a territorialidade humana aponta para o perigo de se enveredar para um determinismo geográfico (RAFFESTIN, 1993; HAESBAERT, 2019). Buscando diferenciar a territorialidade humana de qualquer noção determinista, Raffestin (1993, p. 161) considera que a territorialidade "se inscreve no quadro da produção, da troca e do consumo das coisas”. Como é fruto das relações sociais circunscritas em um determinado espaço e momento, estas podem ser mais ou menos estáveis, mas não são, de forma alguma, estáticas ou determinadas. Portanto, a análise das relações de poder (territorialidades) sobre as malhas, redes e centralidades (arranjo territorial) deve ser capaz de revelar os elementos constitutivos das relações (atores, os projetos, as estratégias, os meios, os códigos, os componentes do espaço e do tempo) para desvelar suas simetrias e dissimetrias.

Portanto, diversamente da concepção clássica, o território, na visão de Raffestin, não se resume ao espaço físico, material, mas consiste no produto deste com as relações sociais. Esta é a concepção de território que será utilizada no presente estudo: a de espaço no qual se dão as relações de poder.

\subsubsection{Território e TDR: entendendo o processo}

Segundo Saquet (2015), a geografia do poder de Raffestin propõe que as relações de poder se traduzem na territorialidade e produzem o território; e este, por sua vez, encontra-se em constante processo de territorialização-desterritorialização-reterritorialização (TDR) pelas relações de trabalho, pela influência dos signos e do sistema territorial que operam no cotidiano e conformam uma "geografia da territorialidade”. O autor assinala que a renovação conceitual "histórico-crítica" recai sobre os estudos territoriais e o "território" a partir de "interpretações sobre a complexidade dos problemas territoriais, ou seja, sobre a heterogeneidade, as combinações territoriais e a transformação política do próprio território” (SAQUET, 2015, p. 
58), cuja influência de Gilles Deleuze e Félix Guattari se deu pelos conceitos de “desterritorialização e reterritorialização (TDR) evidenciando os fluxos, as conexões, as articulações, a codificação, a decodificação, o poder, o desejo, e a reprodução ampliada do capital” (SAQUET, 2015, p. 58). Bassani, ao comparar as formulações sobre território na década de 1980 na geografia e na filosofia, sobre a concepção de Raffestin e Deleuze e Guattari, afirma que:

Está implícita nas suas reflexões [de Raffestin], e na substanciação da ideia de território como processo, ao invés de campo espacial a priori, a territorialidade dos acontecimentos políticos e sociais, em linha que seus pares na Filosofia [D\&G] estão colocando o conceito de territorialização como ato existencial primordial.

(BASSANI, 2019, p. 64)

De acordo com o urbanista, esses “palavrões” (conceitos de territorialização [de+re] desenvolvidos por Deleuze e Guattari) tomaram quase vida própria na contemporaneidade nos enunciados de coletivos no ativismo urbano, argumentando que a "noção de territorialização” (e a prática dela) molda seus discursos, conferindo uma “densidade insurgente” (BASSANI, 2019).

A dupla Gilles Deleuze e Félix Guattari metaforiza: “colocamos nossa assinatura num objeto como fincamos nossa bandeira na terra” (DELEUZE \& GUATTARI, 1997, p. 107), no intuito de associar as "marcas territoriais”, ou a demarcação de um território por um indivíduo, num ato geopolítico e de poder. Neste sentido, “assinatura” é a metáfora que Deleuze e Guattari (1997) utilizam para caracterizar as “qualidades expressivas” de forma individual. Na medida em que os indivíduos se relacionam entre si - e com o território - de forma constante ou variável, os resultados dessas interações constituem o que os autores chamam de "motivos e contrapontos territoriais", cuja "relação do território com impulsos interiores ou circunstâncias exteriores" agora apresentam uma "marca coletiva", ou um "estilo" (DELEUZE \& GUATTARI, 1997, pp. 108-110). Para exemplificar, os autores evocam a etologia e o conceito de "ritualização”, que exprime o comportamento/rituais animais e a conexão com o território. As imagens que as metáforas trazem à tona revelam um intenso movimento dialético do "eu" com o "outro" e com o mundo sobre o território, por meio dos exemplos emprestados da etologia (o canto territorial do pássaro). Para Deleuze e Guattari (1997, p. 111): “o território é primeiramente a distância crítica entre dois seres de mesma espécie: marcar suas distâncias”. Com base na afirmação dos autores, pode-se notar a presença do material (espaço/distância), 
mas também do simbólico, pois considera os impulsos e expressões de cada ser no seu entorno, no seu "pedaço" de terra.

Então a minha inserção no processo foi essa, eu conhecia bem o território porque sou de lá, eu sabia bem onde eu tava pisando, e o que facilitava porque as relações com as organizações e os movimentos [...].

(PARTICIPANTE 6, entrevista concedida a Diego Fernandes, 2019)

Com base no trecho acima é possível perceber a noção de território na concepção de Deleuze e Guattari: esse espaço onde o indivíduo sabe onde está pisando, ou onde não deve pisar, onde os territórios (e as territorialidades) estão bem demarcadas pelos grupos que o compõem. Esse “saber onde pisar” pode ser entendido como o territorializar, na perspectiva de Deleuze e Guattari. Os filósofos destacam que os “dois aspectos do território” são a possibilidade de "assegurar” e "regular” a "coexistência de membros da mesma espécie”, como também a possibilidade da “coexistência” de “diversas espécies no mesmo meio”; e consequentemente os “dois efeitos notáveis” no território são a "reorganização das funções” e o "reagrupamento das forças” dos diferentes meios numa só porção composta pelas "forças da terra”. No primeiro efeito "há uma territorialização das funções que é a condição de seu surgimento como 'trabalhos' ou 'ofícios'” (DELEUZE \& GUATTARI, 1997, p. 113); no segundo, há sempre um lugar onde todas as forças se reúnem no território que remete a um centro: “[...] as marcas territorializantes desenvolvem-se em motivos e contrapontos, reorganizam as funções, reagrupam as forças” (DELEUZE \& GUATTARI, 1997, p. 114).

Eu acho que sim - acho não, eu vejo isso - a UPA [Unidade de Pronto Atendimento] é um grande exemplo. O Mário retoma no bairro as lutas pela saúde, a UPA vai ser inaugurada, uma UPA que ficou parada 4 anos, então tem toda uma mudança local nos equipamentos de saúde por conta, por exemplo, do envolvimento das agentes de saúde com o território, elas tiveram formação com o Fofão e com o Mário, sobre $o$ que é esse território, o que é o TICP [Território de Interesse da Cultura e da Paisagem].

(PARTICIPANTE 6, entrevista concedida a Diego Fernandes, 2019)

No trecho destacado da entrevista é possível enxergar os efeitos notáveis no território com a reterritorialização de um agente, por meio de sua expressão individual em prol de uma pauta coletiva, como a implementação de uma UPA que ficou “quatro anos parada”. Ademais, 
pode-se perceber o estabelecimento de um novo campo de forças, ou da recodificação de um território “dado” e de um código definido por meio de territorialização de um novo código desejado, expressado pelo movimento do TICP e, consequentemente, de um novo território (esse território). Portanto, a ideia de território como processo, como construção contínua aparece no momento em que a função da UPA é ativada, bem como nos momentos de formação política entre os agentes que disputam esse outro território.

Desse modo, Deleuze e Guattari assumem que “cada meio possui seu código” próprio e que há "transcodificação entre os [diferentes] meios”. Assim, assumem que o território se dá pela “descodificação” e a territorialização como um fator que se dá “nas margens do código de uma mesma espécie e que dá aos representantes separados desta espécie a possibilidade de se diferenciar” (DELEUZE \& GUATTARI, 1997, p. 114). Portanto, a territorialidade pode ser entendida como um fator de diferenciação indireta entre membros de uma mesma espécie.

[...] então eles estão falando de nós lá [câmara municipal de São Paulo], e quando eu vejo alguém falando de território lá, eu tenho vontade de falar "pára de falar de território porque você não viveu o território, eu vou chamar alguém que viveu o território e construiu o território aí vai vir aqui e vocês conversam”, porque você ouve uns absurdos...

(PARTICIPANTE 2, entrevista concedida a Analu Garcia, 2019)

A partir desse trecho, aponto para uma situação que D\&G chamaram de transcodificação entre os diferentes territórios. Neste caso, uma territorialidade com uma marca coletiva forte na cidade que estava sendo discutida no território político (“oficial”) da Câmara Municipal. É interessante notar, pelo conteúdo da entrevista, o real significado de político que produziu o território em questão, a partir das relações que realmente tocaram o chão, a terra e experimentaram a multidimensionalidade e multiescalaridade dos conflitos e dos poderes envolvidos no processo de constituição territorial.

Transportando o debate para autores que escrevem já neste século, e buscando assim aproximar-me dos casos que serão analisados nesta pesquisa, torna-se evidente que as múltiplas camadas, para além da do poder (dimensão política), incidem e se misturam de forma intensa nos territórios. Nesse sentido, Marcelo de Souza (2020) assinala que além da dimensão política, as dimensões cultural-simbólica e econômica podem estar presentes na gênese do território (motivações para conquista) ou no interesse dele (motivações para mantê-lo), e ressalta a importância de todas as dimensões configurarem as análises sobre o território, pois estão 
imbricadas nos processos de territorialização ou desterritorialização, como em ações de movimentos sociais emancipatórios ou grupos sociais vulneráveis, respectivamente. Ademais, destaca que o conceito de território pode ser aplicado na dimensão do cotidiano e operar em escalas geográficas muito pequenas, como a que denominou de “nanoterritório” (uma rua ou uma ocupação de um prédio em uma área central por indivíduos sem-teto), isso é, a escala “dos oprimidos e de suas táticas” e dos “micropoderes” (De CERTEAU, 1996; FOUCAULT, 1984, 1986, 2008 apud SOUZA, 2020, p. 105). Muitas das ações de territorialização de movimentos sociais emancipatórios têm uma duração efêmera, configurando uma "prática espacial insurgente” e originando “territórios dissidentes” (SOUZA, 2020, p. 106).

Desse modo, a abordagem de Saquet (2015) para o conceito de territorialização é definida como:

[...] apropriação social de um fragmento do espaço a partir das relações sociais, das regras e normas, das condições naturais, do trabalho, das técnicas e das tecnologias, das redes (de circulação e comunicação) e das conflitualidades que envolvem diferenças e desigualdades bem como identidades e regionalismos, historicamente determinados.

(SAQUET, 2015, p. 39)

A compreensão de Saquet (2015) para territorialidade vai além do simples "uso do território”, pois busca compreender as diversas camadas em que as práticas espaciais estão engendradas no modo capitalista de produção, envolvendo “conflitos, ritmos, apropriações, dominações, identidades e diferenças, redes, alienação e exploração”. Neste sentido, a territorialidade consiste em organização, mobilização e luta política, e está diretamente relacionada ao poder, ou aos campos de poder, constituídas histórica e geograficamente (SAQUET, 2015). O autor ressalta, ainda, a importância da análise das diferentes escalas para uma abordagem histórico-crítica e relacional. Nesta perspectiva, “o território é compreendido como espaço de mobilização, organização, luta e resistência política. A territorialidade como práxis de transformação do território, na tentativa de conseguir autonomia, justiça social, repartição da riqueza, proteção ambiental etc. [...]” (SAQUET, 2015, p. 103 - grifo do autor). Para este trabalho interessa esta interpretação de território e territorialidade, a fim de compreender os territórios de resistência que se constituíram nas periferias de São Paulo, em especial os que serão tratados no terceiro capítulo. 
Esse lugar tem muita coisa, sabe qual o diferencial daqui? [...] é a trajetória de luta aqui tem um clima diferente, a gente tá aqui, mas daí o que que acontece, eu lembro que lá no Jardim Rincão, na escola Leonel França, eu participei do conselho de escola e parecia uma família, eu ficava lá o dia inteiro e só ia embora porque tinha que ir pra faculdade, senão não ia nem embora, a gente tinha amizade com o cara da padaria, a mãe ia buscar as crianças, a gente batia papo, tinha reunião manhã tarde e noite, o diretor era meu amigão, eu voltei lá depois de dez anos, o território tava todo ocupado de casas habitacionais, feitas de mutirão, eu voltei lá em 2012, você percebe que o lugar avançou, tinha uma escola, agora tem não sei quantas, tinha poucas casas, agora tá ocupadérrimo, tudo casa, prédio, mercado, loja. Eu vejo que lá já era parecido com Perus, porque tinha essa efervescência das pessoas de lutar, a igreja fazia parte das lutas, tinha aqueles cursos na igreja de falar sobre políticas, eu participei na luta pelo Instituto Federal.

(PARTICIPANTE 2, entrevista concedida a Analu Garcia, 2019)

O trecho acima demonstra essa territorialidade como "práxis de transformação do território" e o território como "espaço de mobilização, organização, luta e resistência política”, apontados por Saquet (2015). A diversidade de imagens que vem à tona com esse relato não traz apenas o conteúdo informativo de luta-resistência-conquista (ritualização), mas também o significado e o ritmo que essa práxis cotidiana de casa-trabalho-movimento-organizaçãoformação de base (ritornelo) conforma na marca coletiva (DELEUZE \& GUATTARI, 1997) do território.

Outra definição também relevante ao presente estudo é a tratada por Rogério Haesbaert (2019), com uma abordagem mirada no século XXI, em que não só a materialidade espacial constitui processos relacionais, mas também a virtualidade do "meio técnico-científico informacional” (SANTOS, 1996 apud HAESBAERT, 2019) incide e conforma uma série de relações e “territórios-rede”. O geógrafo defende que a desterritorialização é um mito. Haesbaert afirma que a discussão “moderna-pós-moderna” sobre a desterritorialização tem relação com os processos econômicos, políticos e culturais do mundo capitalista globalizado, sob uma perspectiva generalizada do que é o processo de desterritorialização e uma associação intensa ao predomínio de uma sociedade altamente conectada, em rede, “descolada” do território, apontando para o “fim do território” (HAESBAERT, 2019). A aparente contradição na tese do autor se explica quando sua argumentação incide sobre uma convivência de múltiplas territorialidades, causadas justamente pela nova dimensão relacional promovida pela ampliação dos acessos às redes (de circulação e comunicação), ocasionando a criação de territórios-rede 
por meio da sobreposição de diversas escalas, intensidades e dimensões. Desse modo, os processos de desterritorialização que vêm sendo discutidos amplamente na pós-modernidade, configuram-se, na verdade, como uma "intensificação da territorialização, no sentido de uma 'multiterritorialidade'”' (HAESBAERT, 2019, p. 32).

O que entendemos por multiterritorialidade é, assim, antes de tudo, a forma dominante, contemporânea ou “pós-moderna”, da reterritorialização, a que muitos autores, equivocadamente, denominam desterritorialização. Ela é consequência direta da predominância, especialmente no âmbito do chamado capitalismo pós-fordista ou de acumulação flexível, de relações sociais construídas através de territórios-rede, sobrepostos e descontínuos, e não mais de territórios-zona, que marcaram aquilo que podemos denominar modernidade clássica territorial-estatal. O que não quer dizer, em hipótese alguma, que essas formas mais antigas de território não continuem presentes, formando um amálgama complexo com as novas modalidades de organização territorial.

(HAESBAERT, 2019, p. 338 - grifo nosso)

Apenas para ilustrar, um exemplo de um território-rede na escala individual seria o da construção do meu território pessoal em uma cidade cosmopolita como São Paulo. Vivi metade dos meus 29 anos em uma cidade do interior do Mato Grosso, com pouco mais de vinte mil habitantes. Completei o segundo grau em uma cidade do interior de São Paulo, fiz graduação na capital mato-grossense - Cuiabá -, intercâmbio acadêmico em Lisboa (Portugal) e, nos últimos cinco anos, construí (e vivenciei) diversos territórios em minha experiência na cidade de São Paulo: o território da pós-graduação Escola da Cidade, o território dos arquitetos da Rua General Jardim, o território do Largo São Bento, o território dos garçons e garçonetes da Avenida Juscelino Kubitschek, o território das vendedoras do varejo, na Oscar Freire e, por fim, o território que só foi possível construir porque veio depois de todas essas intensas recodificações: o território da FAUUSP. Esse último território me possibilitou a territorialização em Perus e no Bororé, os dois territórios que fazem parte desta pesquisa. Após todos esses processos de des-reterritorialização muitos desses territórios ainda permanecem como parte do meu território pessoal pelos "territórios-rede", por meio das redes de comunicação, assim como também a minha “marca” mato-grossense vem comigo aonde eu for, ou seja, eu saio do território, mas o território “não sai de mim” completamente.

Trago o meu exemplo para ilustrar a possibilidade de uma multiterritorialidade na escala individual, mas a multiterritorialidade também pode ocorrer na escala coletiva, como nas 
diásporas de grupos imigrantes. É importante destacar que tanto a multerritorialidade individual quanto a de grupos conformam-se por um complexo de relações econômicas, sociais, culturais, políticas e espaciais, portanto, relações de poder tanto na possibilidade de reterritorializações com ampla liberdade, quanto de desterritorializações impostas e violentas.

Posto isto, cabe ressaltar que interessa a este trabalho a compreensão dessas dinâmicas contemporâneas “flutuantes” (na rede, nos afetos, nas representações e subjetivações) a partir dos “coletivos territorializados" (BASSANI, 2019), o que confere camadas ainda mais complexas às dinâmicas cotidianas e locais nos territórios com a sobreposição de diversas camadas simbólicas, informacionais e territoriais.

É, mas uma delimitação no imaginário, integração por conta da Cultura, etc., e integração no imaginário, tanto é que a gente pegava da Brasilândia vinha e que a gente chamava de estrada trans-Palestina, da Brasilândia até Anhanguera é uma realidade basicamente só, periférica, né. A gente desenhou um projeto que era para ponto de cultura, e aí de início a gente já fez a circulação, nos dividimos em microterritórios e fazíamos essa dinamização, isso em 2009, tateando essa ideia de território. Lançando essa ideia que a gente precisava criar uma identidade que nos coubesse. [...] Na concepção que a gente já tinha era o seguinte: era um território que não tem essas fronteiras, porque você não tem como definir o alcance por exemplo afetivo, ou mesmo histórico em alguns elementos, o ambiente por exemplo, a gente tem uma conectividade com a serra da Cantareira, então não tem fim o território.

(PARTICIPANTE 1, entrevista concedida a Analu Garcia e Diego Fernandes, 2019)

O trecho acima retirado de uma entrevista com uma liderança de um coletivo territorializado mostra essa fusão. Trata-se de um território que, nas conexões comunicacionais, afetivas e de projetos, não tem fronteiras, não tem divisórias, apesar da divisões políticoadministrativas dos distritos que os “separaram” no espaço geométrico representado na cartografia oficial da cidade de São Paulo. Outro exemplo para ilustrar esse território-rede, de que trata Haesbaert (2019), é o Movimento Cultural das Periferias:

É possível você organizar o território do ponto de vista do Movimento Cultural das Periferias, é um plano de poder que a gente traçou, governança local. Qual que é a nossa crença: que você constitui redes fortes, você cria integração local, por que a prefeitura não vai fazer a integração, não vai rolar, sei lá, o CRAS e a educação, não rola. Então o que a gente decidiu, construir um poder a partir de fora, e esse poder 
forçar os caras a se integrarem, mas a gente tem uma governança e essa pressão vai fazer com que eles se mexam.

(PARTICIPANTE 1, entrevista concedida a Analu Garcia e Diego Fernandes, 2019)

Haesbaert (2019) chama a atenção para a diferença entre as redes do território (na acepção moderna ou clássica) e os territórios-rede. No primeiro caso, um exemplo pode ser pelas redes de infraestrutura (concreta) ou redes como as político-administrativas dos vários distritos sob uma mesma jurisdição. Esta rede (e ao mesmo tempo tessitura) se diferencia da rede forte (de poder) que o Movimento Cultural das Periferias construiu como projeto, especialmente pela característica de um território-rede em que não se pode "mais distinguir claramente onde começam e onde terminam” (HAESBAERT, 2019, p. 348).

[...] sair dessa linha tradicional de museu onde tem um espaço com as peças da época que você não pode nem tocar. O nosso é ao contrário, tá dentro já, o morador, você já mora no museu onde você pode vivenciar e pode contar essa história dentro da onde aconteceu esse território, né. Então vai desde as aldeias, processo de colonização, na mineração, industrialização, da ditadura militar, né, até chegar na questão das ações e movimentos sociais, e aí a gente define a nossa ação como o turismo de resistência, que a gente conta é só luta social do território onde os livros didáticos não conta...

(PARTICIPANTE 10, entrevista concedida a Analu Garcia, 2020)

A partir desse trecho pode-se pensar a multiterritorialidade por meio do encontro com múltiplas dimensões territoriais, temporais, escalares e relacionais. Esse relato apresenta uma série de processos territoriais que datam de longo período, desde os processos de colonização até os contemporâneos. São antigos territórios de exploração e expropriação de terra e do trabalho humano, como as cavas de ouro do século XVI, a Fábrica de Cimento Portland Perus, o cemitério Dom Bosco onde foram enterradas clandestinamente ossadas provenientes da Ditadura Militar. Atualmente, por meio da atuação da comunidade cultural Quilombaque, esses territórios “estabelecidos” têm sido recodificados e, portanto, territorializados mediante outras narrativas, herdadas dos corpos negro e indígenas que resistiram a tais processos e hoje reivindicam reconhecimento, reparação, autonomia, direitos sociais e direito à cidade. O turismo de resistência praticado pela comunidade cultural Quilombaque articula fluxos de pessoas e de informações que extrapolam a escala local dos distritos de Perus, Anhanguera e Jaraguá, pois já foram recebidos turistas estrangeiros para conhecer essa territorialidade cunhada de Museu Territorial Tekoa Jopo’i. Para além dessa multiterritorialidade construída 
pela no âmbito do museu territorial, a Quilombaque estabeleceu redes com outros territórios periféricos em seu percurso cotidiano e, mais recentemente, em um contexto de ameaça de remoção, estabeleceu redes de apoio virtuais com artistas brasileiros conhecidos nacionalmente.

Por fim, cabe ressaltar que as entrevistas foram trazidas aqui para a realização de um contraponto entre a densidade conceitual do quadro apresentado, a partir do âmbito acadêmico, e a significação no cotidiano do ativismo urbano pelos coletivos territorializados com os quais dialoguei durante o período de pesquisa. A fala dos sujeitos em questão evidencia um tema importante a ser destacado neste trabalho: a condição periférica em que se encontram territorializados e todas as questões (de poder) por trás desse arranjo espacial, cuja incidência nas bases para organização social e política produz o que chamo de territórios de resistência, tema a ser tratado na seção seguinte.

\subsection{São Paulo: territórios de resistência}

Já é de amplo conhecimento que a periferia ${ }^{24}$ sofreu intensos processos de estigmatização e exclusão socioespacial em sua constituição na cidade: precariedade de infraestrutura urbana, de serviços de transporte, educação, saúde e, mesmo diante (e por conta) dessas condições a população periférica construiu seu habitat. Cito habitat como a casa e a cidade, seus modos de vida, táticas de sobrevivência e, notadamente, a capacidade de organização e mobilização política como forma de luta na cidade, pelo direito à cidade, como proposto por Lefébvre (2016 [1968]) e atualizado por Harvey (2014 [2012]).

\footnotetext{
[...] a família vendo o resto de comprar os terrenos mais baratos e mais afastados, na época a região de Perus era o lugar mais acessível na compra, né. E aí a gente constrói nossa casa na rua, não tinha rua, né. Não tinha nem energia elétrica, o bairro tava começando a desenvolver e a gente estava lá no território de Perus, e minha formação foi toda dentro do bairro, né, toda a construção, todo o desenvolvimento foi através do bairro de Perus.
}

(PARTICIPANTE 10, entrevista concedida a Analu Garcia, 2020)

\footnotetext{
${ }^{24}$ Utilizo a definição proposta por Tiarajú D’Andrea (2020), em que a periferia consiste na construção e compartilhamento de uma consciência periférica, tanto do ponto de vista do compartilhamento de códigos e práticas políticas, artísticas e culturais comuns pelos sujeitos periféricos, como da condição territorial, caracterizada pela condição social de pobreza e vulnerabilidade e pela pelo padrão geográfico de distância e acessibilidade. Sobre a questão territorial, D’Andrea fundamenta-se nos padrões de macrossegregação de Flávio Villaça (1998), no qual o centro de São Paulo foi esvaziado pela elite e a cidade se desenvolveu (com altos padrões de infraestrutura urbana) em um padrão radial concêntrico em direção ao quadrante sudoeste.
} 
Algumas imagens vêm à cabeça durante a leitura desse trecho: estradas de terra, mato, lampião e espaço. Espaço aqui no sentido de distância, de vastidão de terra, "espaço de sobra" com duplo sentido: no de vastos espaços para começar uma vida nova, seja através da (auto)construção da casa própria e na reterritorialização; como também as sobras espaciais a que foram deixados os migrantes no período de intensa urbanização da cidade de São Paulo, notadamente a partir de meados do século $\mathrm{XX}^{25}$. Esses espaços, que antes eram as sobras, hoje são espaços de disputas na metrópole: quando não demole e reconstrói o centro, já densamente ocupado, o mercado imobiliário avança para as bordas da cidade ${ }^{26}$.

Figura 7 - Ilustração da paisagem do bairro de Perus em 2019

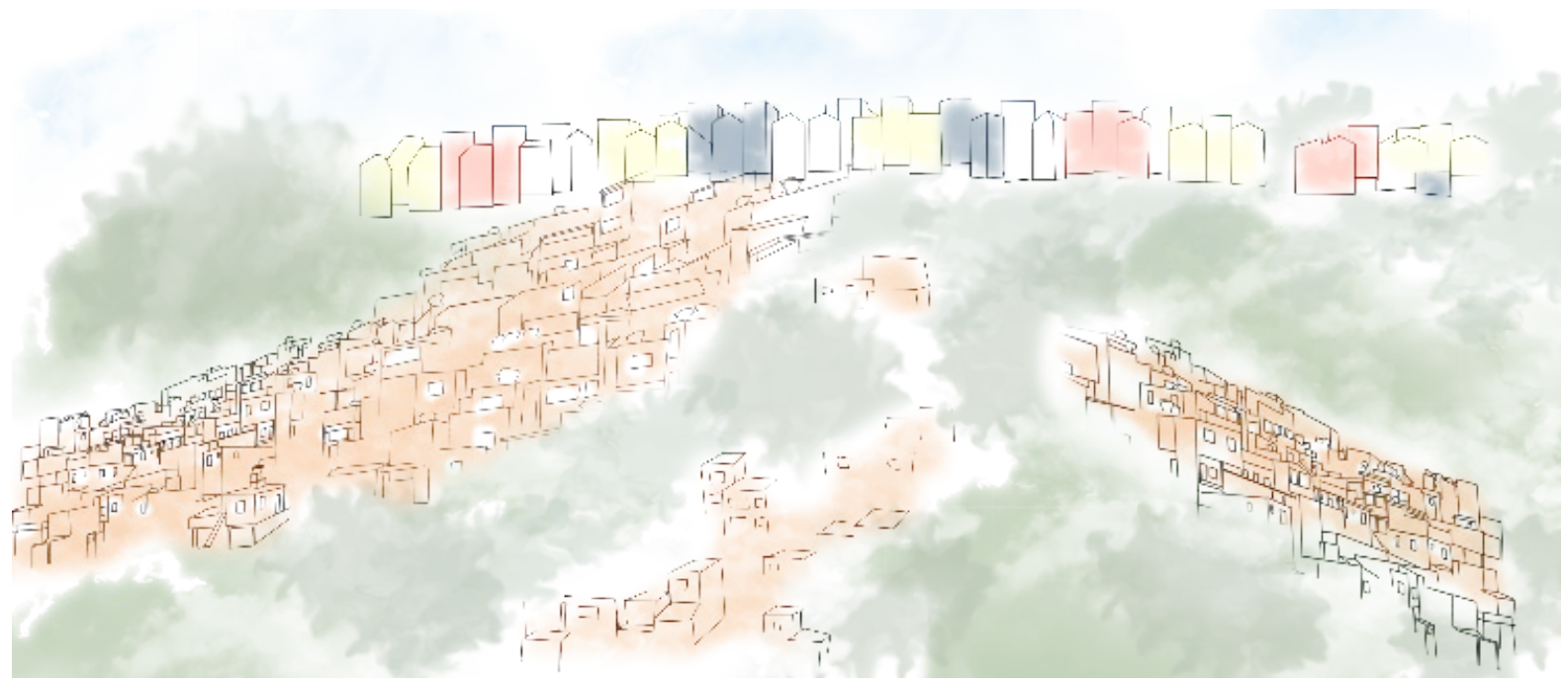

Fonte: idealização da autora, elaboração Camilla Ortega.

${ }^{25}$ Em 1950, a população urbana do país era de 18.782.891, o que representava 36,1\% do total da população total, com uma taxa de crescimento anual de 3,84. Esse número, em 1960, salta para 31.303.034 (44,7\% e taxa de cresc. De 5,24); em 1970, 52.084.984 residentes urbanos (55,9\% e taxa de cresc. De 5,22); e 1980, com um total de 80.436 .409 de população urbana (67,6\% da população do país e taxa de cresc. de 4,44). Dados retirados de Holston (2013, p. 146), com base no censo do IBGE (2001).

${ }^{26}$ O Novo Entreposto de São Paulo (NESP) é um empreendimento privado do setor de abastecimento que será implantando no bairro de Perus, em São Paulo, em substituição à atual Companhia de Entrepostos e Armazéns Gerais de São Paulo (CEAGESP). O NESP faz parte de um projeto maior, o Polo de Abastecimento, Distribuição e Entreposto de São Paulo (PADESP). Disponível em: https://nespsa.com.br/. Acesso em: 24 nov 2020. 
Figura 8 - Ilustração representando a segregação socioespacial, o desenvolvimento urbano de localizações (e paisagens) específicas da cidade, como a do capital financeiro, assentadas na desigualdade

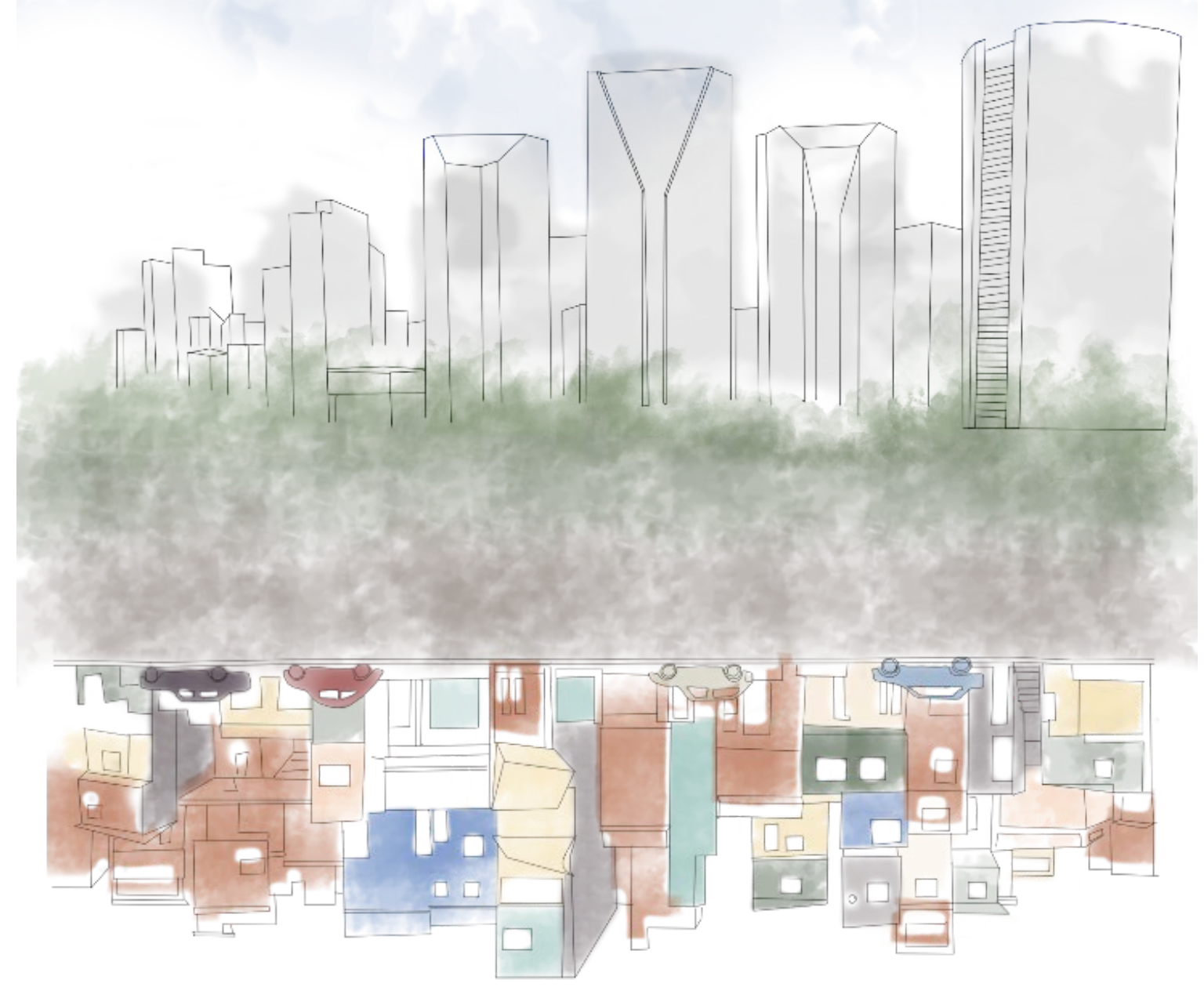

Fonte: idealização da autora, elaboração Camilla Ortega.

A paisagem atual da metrópole São Paulo é muito diferente da retratada (e vivida) nos anos 1970-80, aproximadamente o período em que a família do entrevistado migrou do Nordeste para o Sudeste, até São Paulo. São Paulo, na segunda década do século XXI, produz uma diversidade de paisagens que vão do avanço técnico e científico à violência, das grandes obras de infraestrutura às favelas. Essa leitura apressada de paisagens ideológicas propicia a imagem do espetáculo ou do caos, comprometendo uma leitura mais complexa de processos históricos na relação da sociedade com o meio em que ela se constituiu. Dois exemplos dessas paisagens ideológicas são a Avenida Paulista, por um lado, que representou o cartão postal do 
centro de negócios, da modernidade ${ }^{27}$; e das periferias, por outro, que a despeito de sua heterogeneidade e múltiplas realidades são retratadas de maneira homogênea pela ótica da violência e da pobreza. Tal abordagem foi discutida por urbanistas, não sob o conceito de paisagem, mas de espaço, notadamente a respeito da estruturação e dominação do espaço intraurbano através da ideologia, ao representar a imagem de parte da cidade (onde a elite habita, circula e consome) como sendo a representação da própria cidade ${ }^{28}$. Nesses casos, é importante ressaltar que “o fato de ser uma forma, uma aparência, significa que é saudável 'desconfiar' da paisagem. É conveniente sempre buscar interpretá-la ou decodificá-la à luz das relações entre forma e conteúdo, aparência e essência” (SOUZA, 2020, pp. 48-49).

A decodificação dessa estrutura "moderna” ${ }^{29}$ (e da(s) paisagem(ns) que gerou) deve ser olhada pelos movimentos e contradições que conformaram a urbanização acelerada a partir de meados do século XX, as intensas migrações e a consequente periferização das metrópoles brasileiras. O urbanista Flávio Villaça (2001) argumenta que houve um fator social em comum entre todas as metrópoles na estruturação das cidades: a dominação das elites sobre as classes populares através do espaço urbano, utilizando-se do papel da ideologia, do controle do mercado imobiliário e do Estado, que gerou como fato material a segregação socioespacial.

Em uma leitura também marxista sobre a produção da cidade, Ermínia Maricato (1996) analisa as contradições do processo de produção capitalista da cidade sob a materialização da segregação socioespacial. Uma das questões centrais nesse processo é a terra, enquanto elemento de uma sociedade patrimonialista, e a posse ilegal de terra, enquanto contradição dentro desse processo. Ademais, pontua a relação ambígua e arbitrária do Estado, do mercado e das autoridades em prol da hegemonia da cidade ideológica/formal - "homogênea, símbolo de poder, requinte e modernização"-, em detrimento da cidade “informal”/ilegal (MARICATO, 1996). Nesse contexto, a urbanista analisa que a autoconstrução surgiu como alternativa possível dentro desse sistema que aponta como ambíguo, desigual e gerador da cidade informal. Desse modo, tal condição de ilegalidade/informalidade é “consentida” pelo Estado em áreas da cidade onde a terra não tem interesse do mercado imobiliário, fazendo com quem um problema que deveria ser resolvido através de política pública seja resolvido pelas próprias mãos da classe

\footnotetext{
${ }^{27}$ Na década de 1990 houve campanha publicitária realizada pelo Banco Itaú para eleger a avenida Paulista como símbolo da cidade, segundo Villaça: “uma ostensiva posição para reforçar o ‘novo centro da cidade”” (VILLAÇA, 2001, p. 346).

${ }^{28}$ Cf. VILLAÇA (2001) e MARICATO (1996; 2015).

${ }^{29}$ Coloco o termo moderna entre aspas com base na argumentação desenvolvida pela urbanista Ermínia Maricato (1996) de que as raízes históricas de formação da sociedade brasileira baseadas no patrimonialismo, no privilégio, na exploração da força de trabalho refletem e produzem um cenário onde coexistem o moderno e o arcaico.
} 
trabalhadora. Segundo a autora, a construção da cidade oficial oculta a cidade real, caracterizada pelas ocupações irregulares, população pobre e sem acesso às infraestruturas da cidade (MARICATO, 1996).

Essa condição ambígua, de direitos aplicáveis a uns e não a outros, não é fato novo, mas decorrente de um processo histórico, conforme apontado pelo antropólogo e arquiteto James Holston (2013). Nesse contexto, o antropólogo apresentou uma leitura detalhada das formas como se desenvolveu a cidadania brasileira, desde o período colonial até o início do século XXI, interpretada como “includentemente desigual”. Ao investigar os motivos da persistência de tamanha desigualdade no exercício da cidadania no Brasil, constatou que as respostas não se encontram na atualidade, mas possuem uma raiz histórica sobre a forma como a sociedade brasileira sempre tratou a lei, a terra e o trabalho (HOLSTON, 2013). Desse modo, uma questão central e que reverbera até os dias de hoje é o dilema da terra e o acesso restrito à propriedade fundiária, fator que estabeleceu a moradia ilegal como uma alternativa possível aos pobres na cidade (HOLSTON, 2013).

A partir disso, constatou um fenômeno inovador ocorrido na década de $1980^{30}$ : o surgimento de uma cidadania insurgente (HOLSTON, 2013), cujas conquistas extraordinárias incidiram em nível nacional ${ }^{31}$, como as pautas populares incluídas na Constituição Federal de 1988. Através da análise histórica, o autor argumenta que a urbanização acelerada a partir de meados do século XX, as migrações e a periferização das metrópoles brasileiras constituíram esse paradoxo da cidadania insurgente, em que os sujeitos desprovidos de direitos e condições urbanas decentes se organizaram em movimentos sociais e (auto) construíram seu próprio habitat e condições de urbanidade para a sobrevivência nas periferias de São Paulo, durante as décadas de 1970 e 80 (HOLSTON, 2013).

\footnotetext{
${ }^{30}$ Durante as décadas de 1970 e 1980 em São Paulo houve uma intensa mobilização social a partir do trabalho das Comunidades Eclesiais de Base (CEBs) da Igreja Católica com o Partido dos Trabalhadores, profissionais, acadêmicos progressistas e a classe trabalhadora (em grande parte constituída por moradores das periferias urbanas); as principais pautas na década de 1970 eram por moradia e infraestrutura urbana (HOLSTON, 2013). A despeito do endurecimento político da ditadura militar, essas décadas "perdidas” (devido à austeridade fiscal) substanciaram intenso trabalho de base e mobilização política, tendo como grande expoente o movimento e luta pela Reforma Urbana (MARICATO, 2015).

${ }^{31}$ A Constituição de 1988 veio romper com um modelo autoritário e antidemocrático, instituído anteriormente pelo regime militar que governou o país de 1964 a 1985. Neste contexto, alguns avanços podem ser verificados formalmente no que tange ao aparecimento da cidadania como princípio fundamental da República (art. $1^{\circ}$, I, CF/1988), bem como a transformação da "função social da propriedade", antes princípio da ordem econômica na Constituição de 1967, em um “direito fundamental do indivíduo e da coletividade” na Constituição de 1988 (art. $5^{\circ}$, XXIII, CF/1988). Ademais, a Constituição de 1988 dedicou um capítulo autônomo dentro do Título Relativo à Ordem Econômica e Financeira para tratar da Política Urbana, em seus artigos 182 e 183. O Estatuto da Cidade (Lei 10.257/2001) regulamenta os referidos artigos 182 e 183.
} 
Ao abordar os principais conflitos históricos em torno dos direitos de cidadania no Brasil, como terra, moradia, trabalho e direitos, Holston (2013) buscou investigar como a cidadania atravessou essas questões e se desenvolveu, ou foi restringida, ao longo da história, a partir de regimes de trabalho, políticas fundiárias e legislação. Segundo o autor, a cidadania moderna legitimou-se no bojo da formação do Estado-nação, portanto, seguiu associada à escala nacional (cidadania nacional) e serviu, em grande medida, à dominação do poder do Estado como uma espécie de "status-trunfo", na medida em que qualificava ou criava marcadores de distinção sobre quem poderia ou não ser considerado cidadão. Em sua análise histórica, ao comparar os projetos de governos no Brasil e as práticas sociais, o autor destaca dois grandes momentos: o primeiro, iniciado na década de 1930, com projeto de modernização e desenvolvimento urbano, e o segundo com a tomada de consciência e ação política dos trabalhadores que serviram a esse “desenvolvimento” urbano.

Uma é a promoção, por agências estatais e organizações de elite, de projetos para transformar a população pobre urbana numa força de trabalho moderna, produtiva e disciplinada - projetos de desenvolvimento urbano, reforma fundiária e empreendimentos públicos. A outra é o engajamento da classe trabalhadora nesses projetos, que inevitavelmente as reformula. Assim, nos anos 1930, promotores da modernização do Brasil propunham a propriedade da residência como forma de “racionalizar” os trabalhadores em torno dos valores da propriedade e da moradia unifamiliar. Porém, quando empreendedores públicos e privados abriram as periferias a moradias para a classe trabalhadora, a segregação urbana que criaram politizou os trabalhadores que lá se estabeleceram - produzindo uma nova racionalidade, mas não a que os promotores previram.

(HOLSTON, 2013, pp. 49-50 - grifo nosso)

A partir do seu estudo de caso em dois bairros da periferia de São Paulo e da análise histórica e sociológica sobre a cidadania brasileira, Holston (2013) constata que a cidade consiste em uma arena privilegiada para o desenvolvimento de uma nova cidadania e, desse modo, assinala quatro elementos principais que fundamentam essa constatação: i) a organização e mobilização popular centrou-se na questão da moradia; ii) houve a formulação de uma agenda em que a experiência urbana também se constituiu como central; iii) a cidade foi privilegiada como referência de comunidade política; iv) as contribuições que os moradores deram à cidade (a partir de sua construção) fez com que essa agenda de direitos fosse legítima (HOLSTON, 2013). A questão central na argumentação do antropólogo é a mudança na subjetividade dos 
cidadãos pobres ao perceber seus potenciais e direitos, através de sua realização pessoal, como a construção da casa própria e da coletiva, ao se perceberem como construtores da cidade.

\begin{abstract}
No caso de São Paulo, mostro que as classes trabalhadoras desenvolveram um novo sentido de cidadania a partir de suas contribuições para a construção da cidade, ao erigir casas e bairros; para o seu governo, com o pagamento de impostos; e para sua economia, por meio do consumo. Assim, ao construir as periferias urbanas, os trabalhadores de São Paulo se tornaram proprietários de imóveis, fiscais e consumidores modernos. Através do desenvolvimento dessas identidades sem precedentes, passaram a se ver como cidadãos-contribuidores, dotados de direitos enquanto partes interessadas da cidade.
\end{abstract}

(HOLSTON, 2013, p. 49 - grifo nosso)

Essa cidadania insurgente é um fenômeno que emerge nesse momento histórico do Brasil, mas ela não extermina a "cidadania diferenciada", a cidadania "includentemente desigual”, como denominou Holston (2013). Pelo contrário, elas convivem e tensionam uma a outra causando intensa instabilidade sob o argumento de que possuem “direitos do cidadão” em defesas de interesses antagônicos, configurando o que o autor chamou de "paradoxo perverso da democratização do Brasil” (HOLSTON, 2013, p. 349). Nesse sentido, é importante destacar que a “cidadania diferenciada” brasileira foi formulada com base na qualificação de seus cidadãos por marcadores de diferença como renda, propriedade, gênero, raça, ocupação e educação. Esse dado mostra-se importante para a reflexão sobre histórica e persistente desigualdade, tendo em vista que, desde a colônia e durante todo o Império, os analfabetos podiam votar e a maior restrição de cidadania se dava por rendimentos e posse (os "homensbons”). Nesse sentido, o argumento do autor é de que as eleições serviam para assegurar o poder político local (HOLSTON, 2013). Obviamente, as falsas representações, “votos de cabresto” e muitas outras fraudes eleitorais ocorreram e se transmutaram ao longo do tempo, até chegarem ao que temos hoje como cultura política no país.

Contudo, a educação só passou a ser um fator de restrição à cidadania política a partir do final do século XIX, com as oligarquias no poder político do país e com um projeto de poder conservador (do ponto de vista político) e liberal (do ponto de vista econômico). Cabe lembrar que nesse período houve uma mudança nos fluxos populacionais com a chegada de muitos imigrantes europeus no Brasil para a substituição do antigo regime de trabalho escravista pelo trabalho livre assalariado. Portanto, entre 1881 e 1985 (mais de um século), a educação, ou o 
alfabetismo $^{32}$ tornou-se o principal "status-trunfo" para a elite condicionar quem poderia ser ou não cidadão. Essa condição começa a ser superada pela população, especialmente a urbana, apenas a partir da década de 1970, através da formação popular que tiveram os movimentos sociais. Esse período gestou um cenário de transformações sociais sem precedentes e a cidadania insurgente de que trata Holston (2013): de “força de trabalho" a indivíduos conscientes sobre seu lugar na cidade e na sociedade ${ }^{33}$.

Nesse contexto, é interessante notar que tal processo histórico, a despeito das contradições que engendrou, possibilitou o surgimento de uma mobilização social em torno da conscientização sobre a realidade urbana. Maricato (2015) afirma a necessidade de combater o “analfabetismo urbano e geográfico”, desvelar as correlações de forças que estão por trás das transformações que ocorrem na cidade e na vida na cidade. Esse apelo da urbanista tem caráter revolucionário devido à relação estreita entre poder e conhecimento, notadamente quando essa condição se encontra na "fonte” do poder, como propôs Raffestin (1993, p. 58): “colocamos a população em primeiro lugar: simplesmente porque ela está na origem de todo o poder”. Poder a partir do qual ela mesma poderá construir seus próprios signos, códigos e representação de "potência”.

Você não recebe alguém na sua casa com a sua casa suja, você vai dar um tapa, e isso no bairro e no território acontece muito, as pessoas começam a cuidar do espaço. E a gente não vende miséria, a gente vende potência, todas as trilhas são pra afirmar o que a gente sabe fazer, então a gente vende potência, a gente não vende o exótico. Então isso provoca um reajuste ambiental, o simples fato de circular nos lugares provoca essa mudança nas pessoas, elas passam a olhar pro seu bairro com um pouco mais de cuidado, não querem passar vergonha e começam a agir.

(PARTICIPANTE 1, entrevista concedida a Analu Garcia e Diego Fernandes, 2019)

A representação das periferias como territórios de resistência é significativa, dado seu histórico de exploração e de lutas urbanas, em que novos campos de força se constituíram e

\footnotetext{
32 Em 1890, 85,2\% da população do país era analfabeta. Em 1950, período de intensas migrações do campo para a cidade, $50,6 \%$ da população do país era analfabeta (sendo 66,9\% residente no campo e 26,6\% residente na cidade). Em 1980, esse valor cai pela metade, com 25,5\% da população do país analfabeta (46,3\% do campo e 16,8\% da cidade). Dados retirados de Holston (2013, p. 142), com base nos censos do IBGE (2001; 1950-2000).

33 Quando me refiro a "lugar na cidade e sociedade" não me refiro a uma condição espacial dada, mas à conscientização e leitura de mundo de que falou Paulo Freire $(1981 ; 1996)$, em que o homem ao decodificar os processos e relações por trás da realidade em que vive, percebe a realidade como uma "construção histórica e social”, mas não como um “dado” inexorável, vislumbrando assim a possibilidade de se enxergar como sujeito na história. Cf. FREIRE, 2002.
} 
incidiram sobe as normas que organizam o espaço urbano, o trabalho e, em última instância, a vida. Mas seria possível também chamá-los de “territórios da educação”, se olhados pela ótica da relação entre educação e movimento social, como foi abordado pela socióloga e cientista política Maria da Glória Gohn (2011). A autora destaca que as relações estabelecidas entre as Comunidades Eclesiais de Base (CEBs) da Igreja Católica e movimentos sociais com reivindicações por infraestrutura urbana, durante a década de 1970, podem ser vistas sob o âmbito da educação não formal, relação que se configura com aspectos de educação popular a partir de 1980, período marcado pela redemocratização do país. A década de 1990, paradigmática pela "neoliberalização" das cidades e o consequente aumento de pobreza, desemprego e violência, condicionou outras formas de expressão. De acordo com Gohn (2011) houve uma mudança no perfil dos movimentos sociais, os quais anteriormente possuíam como pauta central a oposição ao regime militar - e passam a aparecer com diversas demandas e caracterizados por movimentos temáticos, em reação às transformações decorrentes das políticas neoliberais. Essa mudança configura o enfraquecimento dos movimentos sociais e o protagonismo de ONGs e entidades do terceiro setor. Segundo Gohn (2011), houve a construção de uma relação entre movimento social e educação, quando a atuação dos atores sociais se deslocou do eixo fábrica-trabalho para as periferias urbanas, com pautas e demandas sobre infraestrutura e melhores condições de vida.

Nesse contexto, a década de 1990 marca o surgimento de um tipo específico de organização social: os coletivos urbanos. Diferente dos movimentos sociais das décadas anteriores, esse tipo de organização não tem uma hierarquia definida, com proposta de maior horizontalidade, e atua com pautas diversas em reação às práticas excludentes que começaram a ocorrem de maneira intensa e visível nas grandes cidades, muitos com o slogan do direito à cidade. O estudo do urbanista Jorge Bassani (2019) aborda esse fenômeno a partir dos enunciados estético-políticos e das práticas de territorialização desses grupos no centro de São Paulo. Seu argumento pauta-se no fato de que, a despeito da utilização diluída de conceitos como território e territorialização, que foram formulados a partir das rupturas epistemológicas em 1960, a simples noção e a prática de territorialização cotidiana confere densidade às suas expressões e manifestações.

Da mesma forma, o sociólogo Tiarajú D’Andrea (2020) argumenta que as lutas urbanas das décadas de 1970-80 deixaram uma memória, ou legado para a geração de moradores da periferia dos anos 1990, os quais transformaram o significado de periferia de estigma para orgulho, um novo código pautado nas "sujeitas e sujeitos periféricos”. Essa transformação se 
deu a partir de alguns aspectos, como a afirmação em tom de denúncia elaborada pelo hip-hop na década de 1990, a criação de uma “consciência periférica” e, a partir dos anos 2000, com o estímulo à produção cultural e a entrada de jovens da periferia nas universidades, a difusão desse novo código.

Apesar dos avanços logrados com os governos populares de Luiz Inácio Lula da Silva e Dilma Rousseff, de 2003 a 2016, as questões históricas e estruturais como a desigualdade e o racismo não foram superadas. Nesse sentido, a geógrafa Silvia Lopes Raimundo (2017) assinala que a formação territorial da cidade de São Paulo permeou “processos de periferização" e construção de “ausências”, e sublinha que, apesar de algumas destas questões terem sido resolvidas do ponto de vista do "mínimo necessário”, com provimento de infraestrutura básica e políticas públicas para a educação, cultura, saúde e moradia, ainda há lugares com alto índice de vulnerabilidade social que compõem as periferias da cidade.

Tabela 1 - Índice Paulista de Vulnerabilidade Social (IPVS) e variáveis de composição

\begin{tabular}{|c|c|}
\hline \multicolumn{2}{|c|}{ Índice Paulista de Vulnerabilidade Social (IPVS) - Variáveis } \\
\hline Socioeconômica & Demográfica \\
\hline $\begin{array}{l}\text { - Renda domiciliar per capita } \\
\text { - Rendimento médio da mulher responsável pelo } \\
\text { domicílio } \\
\text { - \% de domicílios com renda domiciliar per capita até } \\
1 / 2 \mathrm{SM} \\
\text { - \% de domicílios com renda domiciliar per capita até } \\
1 / 4 \mathrm{SM} \\
-\% \text { de pessoas responsáveis pelo domicílio } \\
\text { alfabetizadas }\end{array}$ & $\begin{array}{l}\text { - \% de pessoas responsáveis de } 10 \text { a } 29 \text { anos } \\
\text { - \% de mulheres responsáveis de } 10 \text { a } 29 \text { anos } \\
\text { - Idade média das pessoas responsáveis } \\
\text { - \% de crianças de } 0 \text { a } 5 \text { anos de idade }\end{array}$ \\
\hline
\end{tabular}

Fonte: Fundação Seade, 2010. Disponível em: www.seade.gov.br. Acesso em: 27 fev. 2020. Elaboração: autora. 
Mapa 1 - Índice de Vulnerabilidade Social Paulista (IPVS)

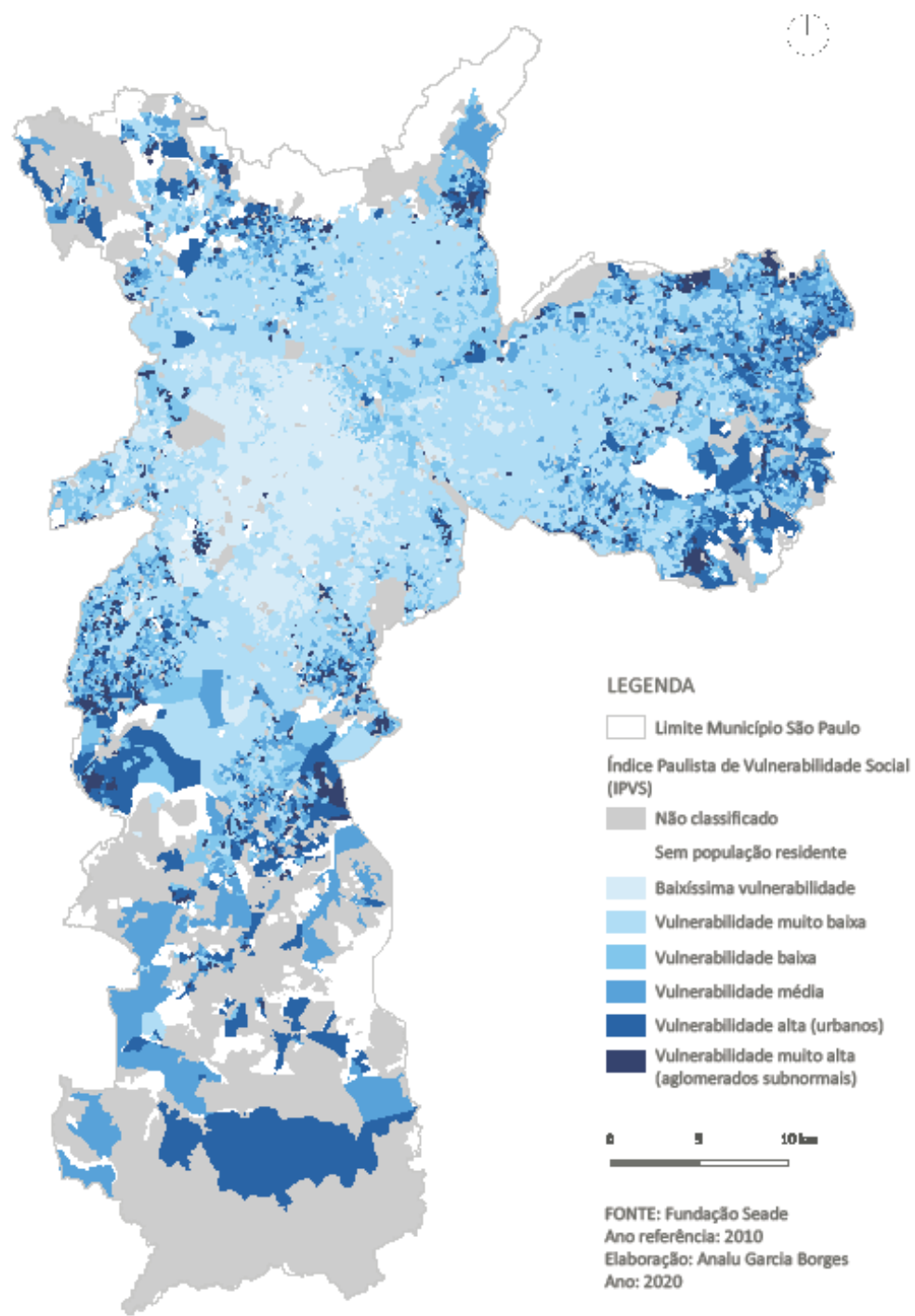

Fonte: Fundação Seade, 2010. Elaboração: autora. 
O mapa acima representa a marca estruturante da sociedade brasileira, a desigualdade social, cuja materialização no espaço pode ser percebida pela formação de territórios de alta vulnerabilidade social. Por outro lado, a emergência de uma consciência periférica, notadamente a partir dos anos 2000, aliada a um trabalho em rede, culminou na aprovação da Lei de Fomento à Cultura da Periferia em 2016, fruto de iniciativa popular encabeçada pelo Movimento Cultural das Periferias ${ }^{34}$. O processo engendrou discussões acerca do conceito de periferia que seria adotado para a proposta da lei, cujos componentes centravam-se notadamente na condição territorial e socioeconômica da população, para que pudesse ser pensada uma (re)distribuição de recursos no território (RAIMUNDO, 2017). Os índices analisados foram renda, mobilidade, recursos para equipamentos públicos de saúde, educação e cultura, e dentre as áreas identificadas na cartografia para a distribuição desses recursos encontram-se os distritos do Grajaú e de Perus ${ }^{35}$, na área considerada com mais de 20\% de domicílios com renda de até meio salário mínimo. Estabeleceu-se que 70\% do orçamento previsto deveria ser destinado para os coletivos desta área (RAIMUNDO, 2017).

Nesse quadro, vale lembrar mais uma vez que Milton Santos trata da cidadania e de sua plena realização por meio de uma distribuição equilibrada dos equipamentos e serviços no território, conforme vimos anteriormente: “Cada homem vale pelo lugar onde está: o seu valor como produtor, consumidor, cidadão depende de sua localização no território” (SANTOS, 2014 [1987], p. 107 -grifo nosso).

\footnotetext{
${ }^{34}$ Cf. RAIMUNDO, 2017.

${ }^{35}$ Os distritos do Grajaú e Perus são o locus de moradia e ação dos coletivos territorializados e da atuação conjunta com a extensão universitária, da qual eu participei durante o mestrado. As análises sobre as práticas desses grupos constam no capítulo 3 desta Dissertação.
} 


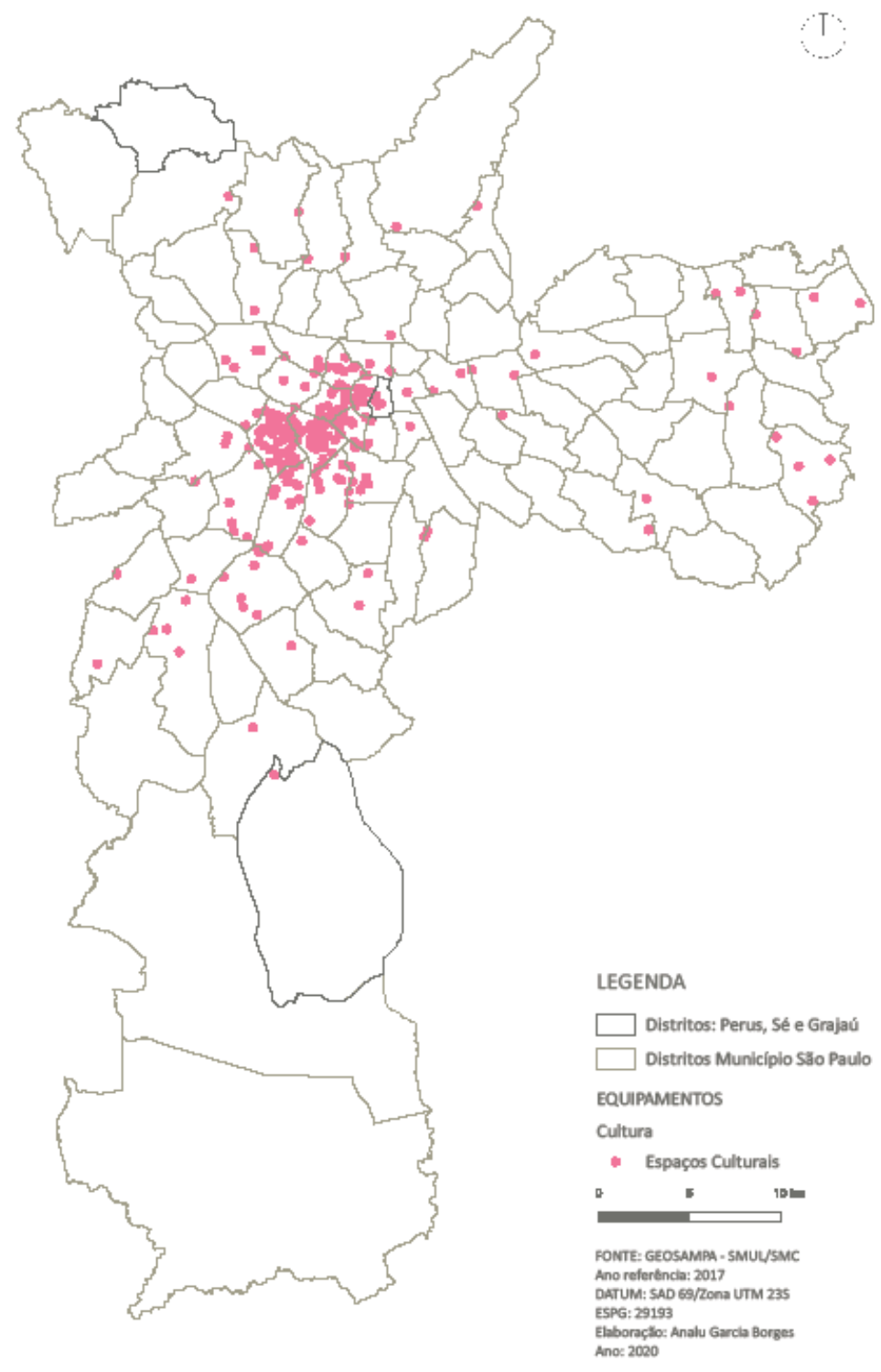

Fonte: GeoSampa, Secretaria Municipal de Licenciamento (SMUL) e Secretaria Municipal de Cultura (SMC) da Prefeitura Municipal de São Paulo (PMSP) - ano de referência: 2017. Elaboração: autora. 


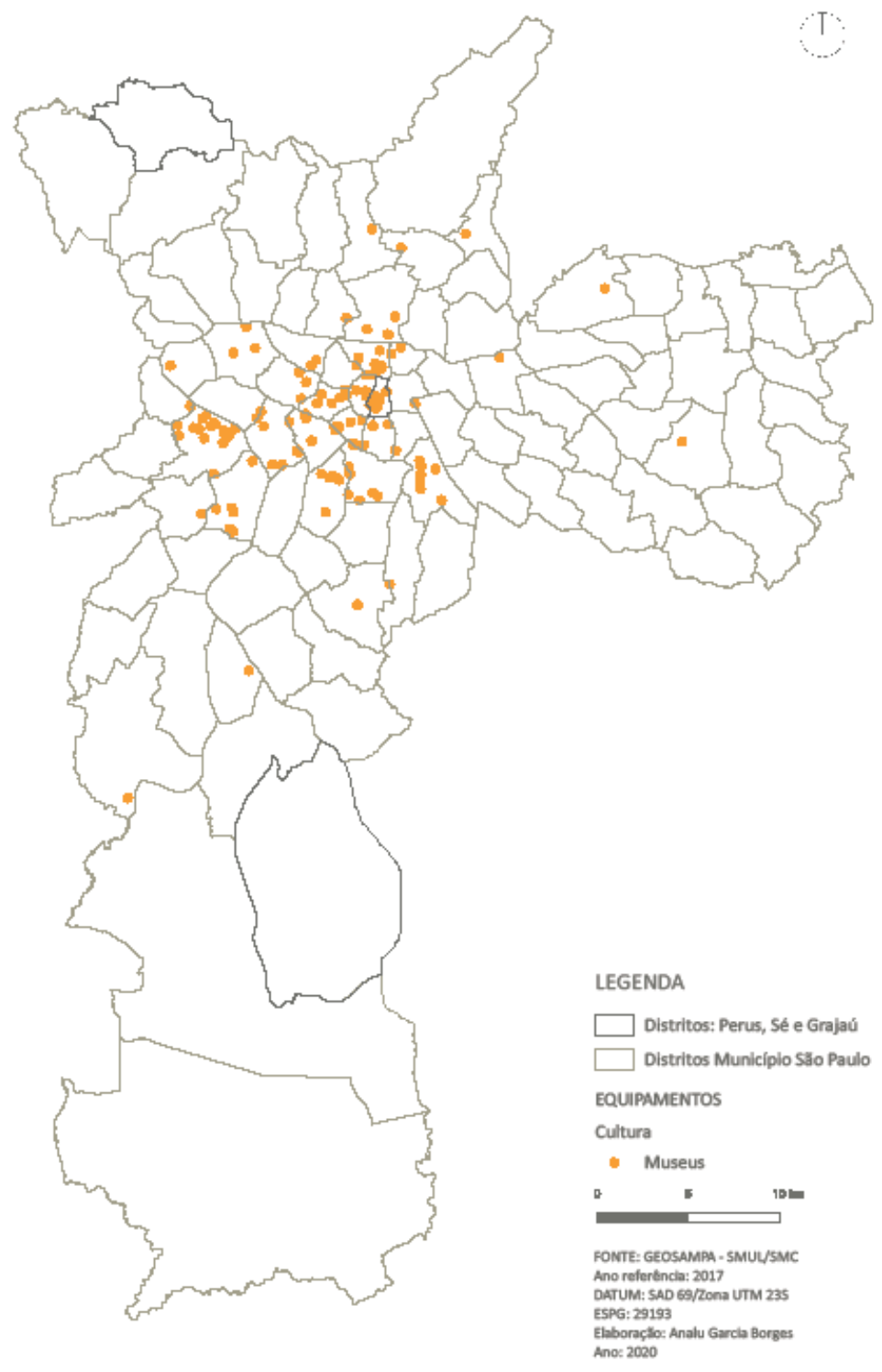

Fonte: GeoSampa, Secretaria Municipal de Licenciamento (SMUL) e Secretaria Municipal de Cultura (SMC) da Prefeitura Municipal de São Paulo (PMSP) - ano de referência: 2017. Elaboração: autora. 


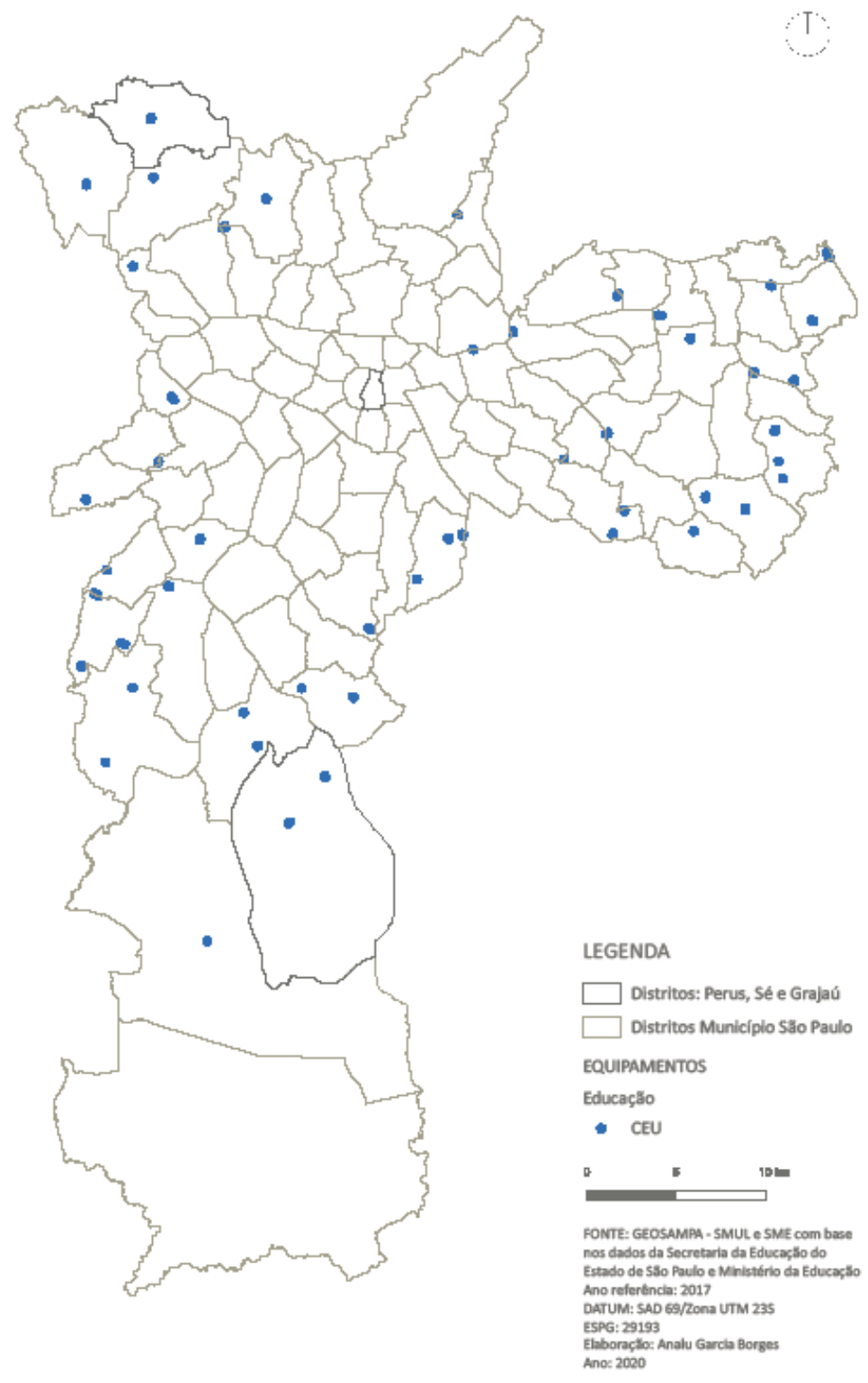

Fonte: GeoSampa, Secretaria Municipal de Licenciamento (SMUL) e Secretaria Municipal de Educação (SME), com base nos dados da Secretaria de Educação do Estado de São Paulo e Ministério da Educação - ano de referência: 2017. Elaboração: autora.

Nesse contexto, os mapas apresentados mostram uma concentração dos equipamentos de cultura, como espaços culturais e museus, nas áreas centrais da cidade de São Paulo. Contudo, os Centros Educacionais Unificados (CEUs) estão distribuídos nas periferias da cidade de São Paulo. Os CEUs são equipamentos de educação que foram implantados em 2002 
na gestão Marta Suplicy (2001-2005), sob inspiração das Escolas-Parque de Anísio Teixeira. Na gestão Fernando Haddad (2013-2017) pretendia-se implantar mais 20 unidades com o objetivo de se integrarem a outros equipamentos públicos do entorno, o que conformaria o Território CEU, pensado para abrigar políticas públicas de educação, cultura, esportes, serviços sociais, além de se abrir e complementar as atividades de escolas de ensino integral, bem como o desenvolvimento de atividades dos coletivos locais. As atividades pensadas no escopo do Território CEU consistem na complementação da formação educacional e cultural, no âmbito do ensino integral, em consonância com o Programa Mais Educação, além de Escola de Jovens e Adultos (EJA), Universidade Aberta do Brasil (UAB) e aulas do Programa Nacional de Formação Técnica de Mão de Obra (Pronatec). Ademais, também deveria comportar salas para os Centros de Referência de Assistência Social (Cras) e módulos da administração do CEU (FRANCO \& HERLING, 2016).

Nesse contexto, a localização e distribuição dos CEUS na periferia foi um dos trunfos da proposta elaborada pela Lei de Fomento à Cultura da Periferia, por meio da demanda de inclusão de todas as Casas de Cultura, CEUs e Territórios CEUs como polos para o Circuito Cultural São Paulo. Apesar do escopo do projeto e da proposta do programa do Território CEU, as administrações locais nem sempre dialogam com a comunidade, o que inviabiliza sua consolidação e articulação de forma plena no território.

Da mesma forma como o Território CEU pode ser pensado como um trunfo para a população da periferia por sua localização e distribuição nos territórios periféricos da cidade de São Paulo, outros equipamentos como escolas públicas e as Unidades Básicas de Saúde (UBS) também se encontram mais capilarizadas no território. 


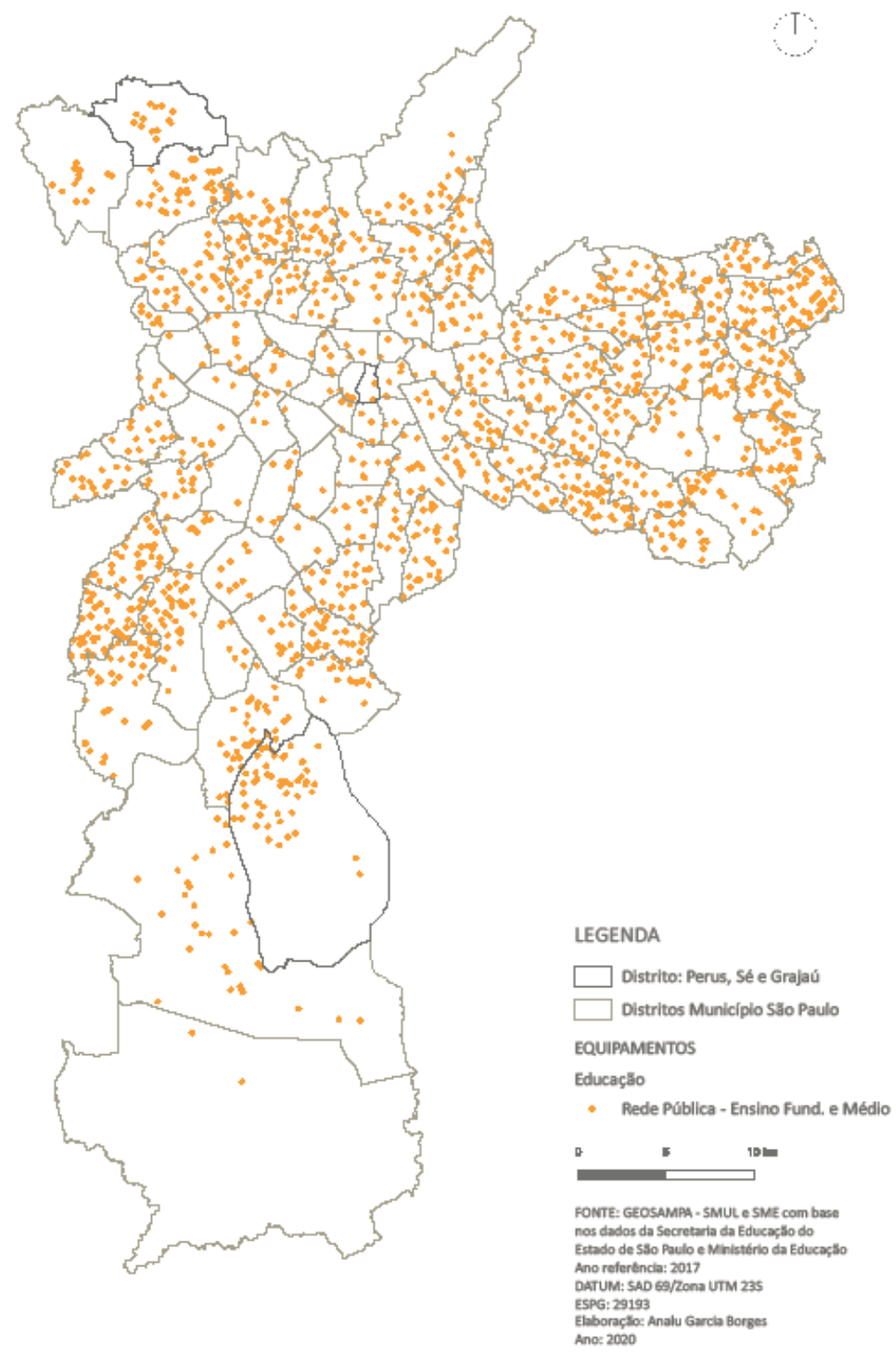

Fonte: GeoSampa, Secretaria Municipal de Licenciamento (SMUL) e Secretaria Municipal de Educação (SME), com base nos dados da Secretaria de Educação do Estado de São Paulo e Ministério da Educação - ano de referência: 2017. Elaboração: autora. 


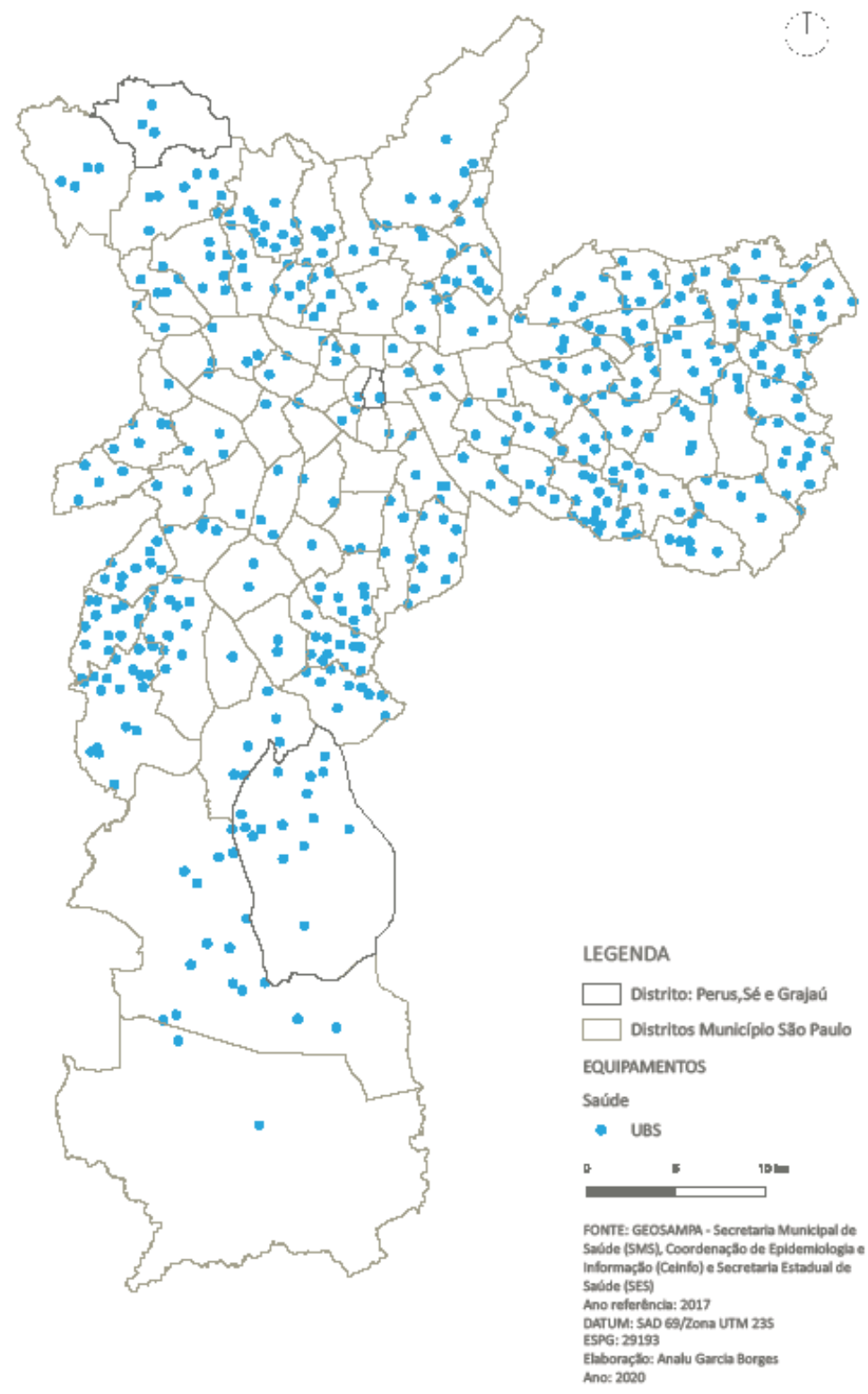

Fonte: GeoSampa, Secretaria Municipal de Saúde (SMS), Coordenação de Epidemiologia e Informação (Ceinfo) e Secretaria Estadual de Saúde (SES) - ano de referência: 2017. Elaboração: autora.

Com a Constituição [Constituição Federal de 1988] nós conseguimos essa ideia da distritalização e desceram muitos recursos, estrutura. Então a gente decidiu construir rede e essa rede vai forçando uma governança local integrada, em que a gente acaba determinando qual é o caminho, como é que se dá, tem uma hora que isso vai ficar tão forte que quem não seguir já entra no constrangimento. Quando o CIEJA, por 
exemplo, que é um lugar de abandono, se levanta e acredita que é possível agir como território educador, isso deixa as escolas chapadas e muitas delas começam a se mexer. É esse movimento que a gente quer produzir, nosso empenho enquanto Quilombaque e alguns coletivos que estão juntos: é construir referências, sempre trabalhar na construção de referência.

(PARTICIPANTE 1, entrevista concedida a Analu Garcia e Diego Fernandes, 2019)

A fala acima aponta para a construção de um outro discurso que também tem um componente territorial e, acima de tudo, simbólico: a construção de um território educador por meio da construção de referências com base na prática cotidiana dos agentes territorializados. Ela também traz a referência da conquista de direitos por meio da promulgação da Constituição Cidadã em 1988, com a entrada de recursos em nível local e a possibilidade de uma organização em rede, a partir do território.

Por fim, é importante assinalar que o último quarto do século XX foi marcado por momentos de rupturas nas ciências que tratam do urbano, em uma escala global, como também pelas lutas urbanas no Brasil, o que ocasionou o surgimento desses “novos urbanismos”, vistos historicamente de forma negativa pela ótica hegemônica. Contudo, a partir da primeira década do século XXI, estimulados por políticas culturais implementadas em governos populares, os coletivos urbanos com atuação no âmbito da cultura têm construído novas narrativas sobre seus territórios, através de expressões artísticas, do resgate de memórias e da formulação de propostas alternativas de desenvolvimento sustentável e autônomo, recodificando os territórios de pobreza e violência em territórios de resistência, de criação e educação. 


\section{EDUCAÇÃO: O CAMINHO DA ESCOLA AO TERRITÓRIO}

O capítulo consiste em contextualizar a educação e sua relação com o território urbano, por meio da apresentação de estudos que se dedicaram a compreender os processos de aprendizagem e o sentido da educação na sociedade, bem como de algumas práticas e políticas adotadas nesse âmbito. O recorte temporal para tratar desta temática está circunscrito no século XX e nas duas primeiras décadas do século XXI. É importante destacar que busco traçar uma "linha do tempo" investigativa, ao estabelecer esse ponto no espaço e no tempo em que a educação visa ser relacionada com a cidade e com as transformações sociais.

Inicialmente será abordado o movimento da Escola Nova com John Dewey, cujo reflexo percebeu-se no Brasil especialmente por educadores como Anísio Teixeira, e as teorias de aprendizagem de Lev S. Vygotsky, com destaque para os processos de formação de conceitos e de aprendizagem significativa, importantes para a pesquisa na medida em que esta busca identificar processos de aprendizagem crítica e criativa nas práticas que serão analisadas.

Em seguida, serão tratados os temas relacionados aos tipos de educação (formal, nãoformal, informal, popular, comunitária e social) e os contextos de seu surgimento como discurso e prática. A compreensão de tais definições tem importância devido à multiplicidade de práticas contemporâneas realizadas fora do âmbito educacional formal, notadamente por meio da ação de coletivos de cultura, educação e educadores sociais, com atuação crescente em territórios de vulnerabilidade social a partir de meados do século XX. Na terceira seção, apresento a concepção de Extensão Universitária da qual partilho, em profundo alinhamento com a perspectiva freireana de “educação como prática de liberdade”, por meio do diálogo e da relação com o território. Para finalizar o capítulo, apresento a década de 1990 e a passagem para o século XXI com discursos e propostas de educação relacionadas diretamente com o território urbano.

\subsection{Século XX: o movimento de renovação pedagógica e as contribuições da psicologia da aprendizagem para a educação}

Eu me proponho a discutir, hoje, aqui, o seguinte problema: Porque escola nova? Porque toda essa agitação transformadora, e tão custosa!.. de práticas e hábitos já tão queridos e que vinham dando os seus resultados? Porque não satisfaz, nem pode satisfazer a "escola velha"?

(TEIXEIRA, 1930) 


\subsubsection{O movimento da Escola Nova}

O movimento da Escola Nova surge no final do século XIX como uma reação à pedagogia tradicional que, fechada em si mesma, tinha como centro do processo de aprendizagem o “professor transmissor” de conhecimentos, cuja figura autoritária deveria moldar um corpo discente dócil e passivo. As principais críticas à pedagogia tradicional centravam-se nesse caráter unidimensional do processo de ensino e aprendizagem, aos conteúdos descolados da realidade concreta da vida cotidiana.

Como alternativa ao modelo tradicional, William Heard Kilpatrick elaborou as bases da Escola Nova, fundamentadas em uma “escola de vida”, que deveria promover uma educação integral, a incorporação de metodologias de projetos com a finalidade do desenvolvimento de uma aprendizagem ativa e uma educação progressiva (TEIXEIRA, 1930). A proposição de uma pedagogia nova que conectasse o conhecimento formal escolar à concretude que se desenhava no ambiente da vida cotidiana, do trabalho e da sociedade parecia mais adequada às transformações que o século XX começava a demandar da sociedade. Segundo Cavaliere (2002, p. 255): "toda a discussão em torno da questão do método, de uma nova visão de como se aprende, continha a idéia de um religamento entre os conhecimentos escolares e a vida em sua plenitude”. Dessa maneira, o principal aspecto da proposta de aprendizagem da Escola Nova consistia na aprendizagem pela experiência, no estímulo intrínseco do aluno em se dedicar a aprender algo.

A partir de meados do século XIX algumas descobertas científicas ${ }^{36}$ mudaram o modo como a sociedade via a natureza e o homem e, em consequência, muitos estudos das áreas humanas foram influenciados por uma base naturalista. A aprendizagem, na abordagem da psicologia da aprendizagem não se limitava apenas em "fixar, comprehender e exprimir verbalmente um conhecimento” (TEIXEIRA, 1930, p. 8), mas sim na aquisição de uma nova postura e habilidade através de uma reação do “organismo” a algo. Essa abordagem “biológica” também foi evidente no movimento de renovação escolar, influenciada pela evolução da biologia e psicologia da aprendizagem e percebida, também, no pensamento de John Dewey, grande expoente desse movimento.

\footnotetext{
${ }^{36}$ Entre elas, uma das mais consequentes é certamente a publicação por Charles Darwin de seu livro A origem das espécies em 1859, por meio do qual sua teoria evolucionista começou a ser difundida.
} 
Figura 9 - Ilustração do processo de ensino-aprendizagem na escola tradicional “conteudista”

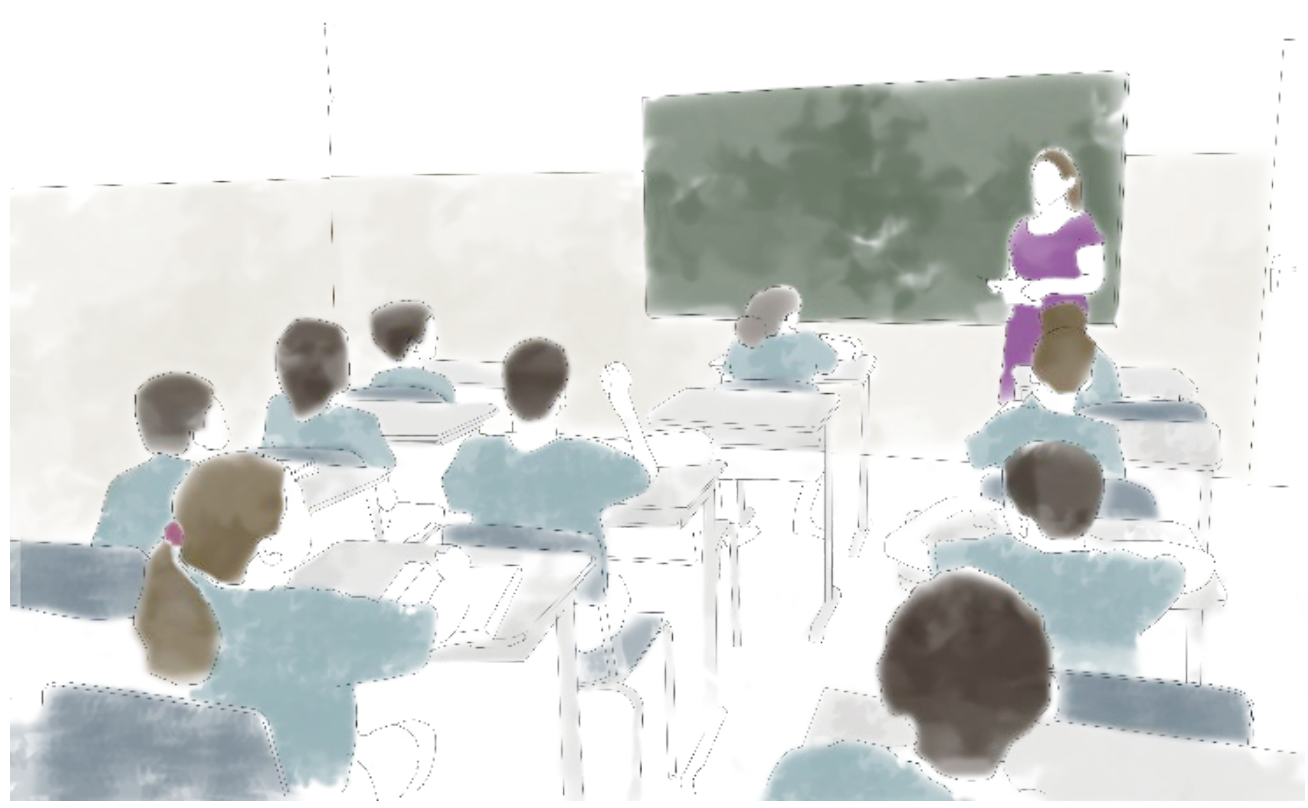

Fonte: idealização da autora, elaboração Camilla Ortega.

Figura 10 - Ilustração do processo de ensino-aprendizagem a partir da experiência, da metodologia de projetos com enfoque em uma aprendizagem ativa

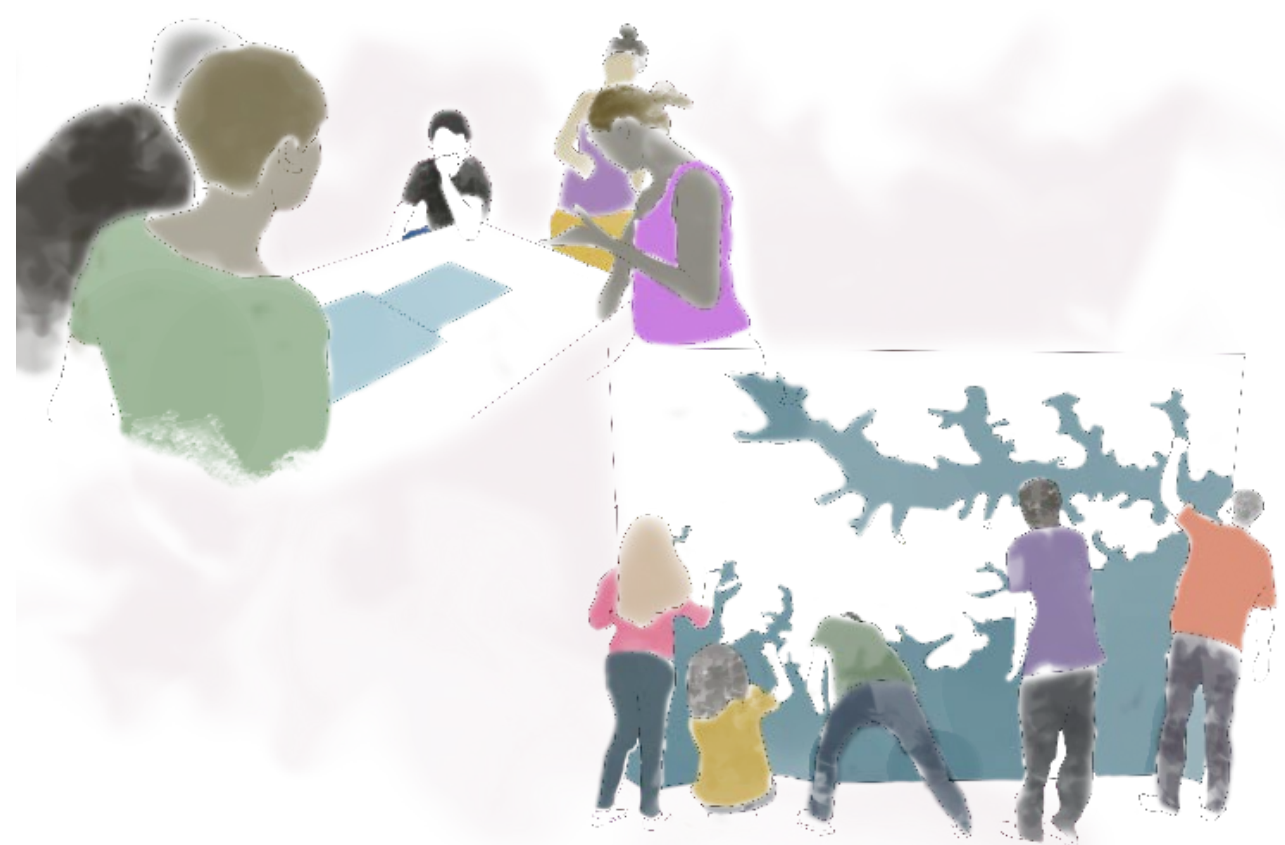

Fonte: idealização da autora, elaboração Camilla Ortega. 
As ideias de John Dewey influenciaram fortemente o movimento pela Escola Nova no Brasil, defendidas por Anísio Teixeira. Teixeira (1930) ao explicar os motivos sociais da necessidade da Escola Nova no Brasil refere-se à necessidade de adequação ao contexto da sociedade moderna no início do século XX: industrial e dinâmica, à luz da ideia de um progresso calcado no desenvolvimento científico e tecnológico que romperia com a ideia de uma sociedade e, consequentemente, de um ensino estático, autoritário e subordinado à natureza, ou ao professor. Ademais, assinala três grandes tendências na sociedade moderna: i) uma nova atitude espiritual do homem; ii) o industrialismo; iii) a democracia (TEIXEIRA, 1930). Deste modo, a visão dos escolanovistas consistia em ressaltar a importância de a escola estar alinhada às transformações sociais decorrente das transformações do modo de produção e da urbanização crescente.

John Dewey, filósofo norte-americano da corrente pragmatista e reformista da pedagogia nova, defendia que a educação deveria ter uma função social e proporcionar uma “ética democrática” em suas ações educativas, em que a escola deveria refletir a sociedade e recriar uma "comunidade democrática” em seu cotidiano de trabalho e ensino (WESTBROOK, 2010). Em vista disso, a criação de "metodologias de trabalho em grupo”, com vistas a se adquirir uma “aprendizagem socialmente interativa” por meio do desenvolvimento de projetos temáticos, esteve presente em sua Escola Experimental na Universidade de Chicago ${ }^{37}$. Alguns pontos centrais da pedagogia de Dewey são a "democracia na educação”, a “aprendizagem socialmente interativa” (TORRES \& IRALA, 2014) e a “educação como reconstrução da experiência” (CAVALIERE, 2002).

Segundo Teixeira (1955), a teoria do conhecimento de John Dewey baseia-se na “filosofia da experiência”, posicionamento contrário ao espírito da época no campo da filosofia, cuja lógica científica se encontrava distanciada da realidade concreta. Portanto, seu pensamento se mostrava revolucionário para os processos educativos vigentes à época, pois buscava unir a tradição e a ciência, o passado e o presente, sob o princípio da “continuidade” entre as formas de saber, o meio, o organismo vivo e o homem, uma vez que buscava formular perspectivas e não um produto acabado (TEIXEIRA, 1955). Desse modo, ao intentar unir as lógicas do processo de busca do conhecimento do senso comum e da ciência, extrapola-se o eixo formal de educação, pois pressupõe-se ser preciso conduzir atividades de aprendizagem tanto no âmbito escolar, quanto no não escolar. "Só uma lógica da experiência, uma lógica da

${ }^{37}$ Cf. mais em Westbrook (2010). 
investigação e da descoberta, como a de Dewey, podem ajudar-nos a vencer as falsas divisões, dualismos e conflitos que vêm criando e nutrindo a injustificada Babel moderna” (TEIXEIRA, 1955, p. 11).

A visão biológica e psicológica está presente nas "bases naturalísticas” da teoria de Dewey, que imbricam uma "matriz biológica” e uma cultural no processo de conhecimento humano, por meio de uma visão holística da relação organismo-meio, portanto os modos de agir com e no meio constituem o hábito que, nos organismos, é a base da "aprendizagem orgânica” e pode se reajustar a depender das alterações que o meio sofra (TEIXEIRA, 1955). A constante busca por "reajuste” ao meio, pela sobrevivência, configura uma matriz lógica no comportamento biológico - “matriz biológica” - que também está presente na matriz lógica do comportamento do homem, no entanto, somada à lógica da investigação pelo conhecimento puro, em si mesmo (TEIXEIRA, 1955). Segundo Teixeira (1955), do mais “primitivo”, ou “natural”, na relação dos organismos com o meio, às interpretações relacionadas ao homem e seu meio (social) - a cultura -, há uma racionalidade lógica. Nesta perspectiva, a linguagem é algo fundamental para Dewey, pois além de ser condição para cultura é, também, produto dela, ou seja, é através da linguagem, dos símbolos e significados que, na cultura, expressa-se o simbólico do comportamento humano (TEIXEIRA, 1955). Portanto, da lógica orgânica/biológica o comportamento “evoluiu” para a simbólica/cognitiva - de matriz cultural -, no contexto cultural em que comportamentos, costumes, símbolos e significados comuns são aprendidos.

O movimento da Escola Nova, portanto, buscava pensar a educação de maneira condizente com a nova vida moderna que vinha se constituindo através dos processos de industrialização, democratização, urbanização (TEIXEIRA, 1930; CAVALIERE, 2002), em consonância com o paradigma da racionalidade científica em voga na época, a partir do qual se atingiria o “progresso”. Contudo, como salienta Cavaliere (2002), a Escola Nova isentou-se de um posicionamento político no questionamento do papel do Estado e do capitalismo monopolista vigente no final do século XIX. Segundo a autora, apesar das contradições inerentes à composição do pensamento engendrado no paradigma da época, o "movimento escolanovista” representou os “avanços do pensamento democrático” (CAVALIERE, 2002, p. 254).

Para finalizar, é importante assinalar que, apesar dos avanços contidos na proposta da Escola Nova, principalmente no que diz respeito à desalienação do processo de ensino e 
aprendizagem, ela não chegou a causar transformações nas bases que estruturam os sistemas de educação, como afirma Cavaliere (2002).

\subsubsection{Teoria sociocultural e o processo de formação de conceitos em Vygotsky}

Antes de iniciar com alguns aspectos da abordagem de Vygotsky, considero importante explicar o porquê de ter me aproximado do campo da psicologia da aprendizagem e não me limitar apenas ao campo da ação social coletiva, por meio de práticas pedagógicas, por exemplo. Um dos motivos consiste na compreensão da dimensão do desenvolvimento cognitivo como parte do desenvolvimento humano e, consequentemente, como parte integrante do desenvolvimento social. O desenvolvimento social, por sua vez, conjuga uma série de fatores, dentre os quais os processos educativos podem mediar processos de desenvolvimento humano e cognitivo individuais e coletivos. Portanto, entendo que ambas as "sementes" devem ser regadas com atenção e dedicação por educadores comprometidos com a conscientização de seus educandos - a do olhar para a dimensão do indivíduo e a do coletivo.

Para começar, é importante situar Lev S. Vygotsky, “teórico multidisciplinar”38 da União Soviética influenciado pelo materialismo histórico e pela concepção da “dupla natureza do ser humano, membro de uma espécie biológica que só se desenvolve no interior de um grupo cultural” (OLIVEIRA, 2019, p. 35). De acordo com Oliveira (2019), o desenvolvimento cognitivo do indivíduo é fruto de um "sistema funcional complexo" cerebral, composto por uma base biológica, desenvolvida pela evolução da espécie humana ao longo de sua história, e pela capacidade plástica cerebral de desenvolvimento por meio do desenvolvimento individual. Desse modo, o desenvolvimento cognitivo deve resultar no que ele denominou de "processos mentais superiores" - o pensamento, a linguagem e o comportamento voluntário, que ocorrem a partir da interação social, mediados por instrumentos e signos que, por sua vez, são construídos social, histórica e culturalmente (OLIVEIRA, 2019).

Entre o sujeito e o objeto de conhecimento existe o "processo de representação mental” que o mesmo realiza para pensar o objeto. Para que o pensamento aconteça ele deve representar esse objeto da vida material e concreta em sua mente, por meio dos sistemas simbólicos relacionados a ele. Para tentar simplificar essa concepção, tomemos como exemplo a igreja.

\footnotetext{
${ }^{38}$ Segundo Oliveira (2019, p. 35), Vygotsky cursou Medicina, Direito e Literatura. Daí a grande ênfase no estudo do funcionamento cerebral como base material do desenvolvimento psicológico. Cabe ressaltar que Vygotsky viveu apenas 38 anos (1896-1934) e deixou uma grande contribuição, continuada com os estudos de seu discípulo A. R. Luria e de sua teoria neuropsicológica.
} 
Convencionou-se entendê-la como local destinado à realização de cultos e orações coletivas. Enquanto objeto materializado, a igreja é um edifício, uma construção, que pode ter diversos formatos, alturas, cores e materiais. Cada grupo social atribui uma representação a essa construção, de acordo com o seu sistema simbólico. Para determinado grupo, a igreja pode ser facilmente representada em uma folha de papel por um quadrado com em triângulo em cima contendo uma cruz na ponta. Nesse espaço, as pessoas se reuniriam sentadas e realizariam orações na maior parte do tempo em silêncio. Outro grupo, por sua vez, pode compreender igreja como uma construção de telhado reto ou em formato oval, sem a presença de uma cruz na parte superior, onde as pessoas se reuniriam em pé para orar por meio da entoação de cantos. O que o grupo social em questão atribuiu de significados à igreja faz parte desse processo de conhecimento, pois a partir dessa operação simbólica o sujeito irá internalizar esses significados, que irão compor o seu desenvolvimento cognitivo. A mudança de um sujeito de um grupo social para outro e a relação com este novo grupo ao longo do tempo pode modificar a sua concepção sobre o objeto.

Desse modo, o processo de desenvolvimento cognitivo ocorre de fora para dentro e depois retorna para fora (MOREIRA, 2011; OLIVEIRA, 2019), ou seja, a partir da interação social, o sujeito capta os significados dos signos e se apropria deles, internaliza-os e os reconstrói internamente para depois utilizá-los coletivamente, por meio das novas funções psicológicas desenvolvidas. Portanto, segundo Moreira (2011), para Vygostky a linguagem (sistema de signos) desenvolve-se durante a interação social, mas também a possibilita.

À presente pesquisa interessa a compreensão do desenvolvimento do indivíduo a partir da “interação social”, como também a construção de conceitos espontâneos e científicos teorizados por Vygotsky, pois serão importantes para as análises sobre as práticas educativas nos territórios de Perus e Bororé. Nesta perspectiva, a aprendizagem se dá em contato com outros indivíduos e com o meio, portanto, a principal "ferramenta” para a “interação social” é a "linguagem” que está inserida em um "processo ativo" de aprendizagem (TORRES \& IRALA, 2014). Um conceito central nesta teoria cognitiva é a "Zona de Desenvolvimento Proximal” (ZDP) que é “a distância entre o nível de desenvolvimento real” - a dos conceitos já dominados pelo educando - e o "nível de desenvolvimento potencial” - conhecimentos que ainda não se desenvolveram completamente e necessitam da mediação de alguém mais experiente para a utilização dos mesmos (VYGOTSKY, 1978 apud TORRES \& IRALA, 2014, p. 73). 
Descobrimos que, em cooperação, uma das crianças podia conseguir resolver problemas concebidos para crianças de doze anos, enquanto a outra não conseguia ir além dos problemas pensados para crianças de nove anos. A discrepância entre a idade mental real de uma criança e o nível que atinge quando resolve problemas com auxílio indica a zona do seu desenvolvimento próximo: no nosso exemplo, esta zona era de quatro para a primeira criança e de um para a segunda. Podemos dizer realmente que o seu desenvolvimento é o mesmo? A experiência ensinou-nos que a criança com a zona mais extensa de desenvolvimento próximo terá melhor aproveitamento na escola. Esta medida dá-nos uma indicação acerca da dinâmica da evolução intelectual mais útil do que a idade mental.

(VYGOTSKY, 2001, p. 103 - grifo nosso)

Esta passagem de Vygotsky dialoga, de forma contrária, com a teoria de Piaget, cuja visão era pautada por etapas de desenvolvimento cognitivo de acordo com seu desenvolvimento biológico. Contrariamente a isso, Vygotsky vai além quando atribui importância da "interação social” e “cooperação” através da "mediação”, o que possibilita à criança aumentar seu nível de desenvolvimento, independentemente de sua “idade mental real”. Deste modo, o diálogo, e em primeira instância a linguagem, possui caráter fundamental no processo de aprendizagem. A partir disso, Vygotsky atribui duas funções à linguagem: o "intercâmbio social” e o “pensamento generalizante”, ou seja, “além de servir ao propósito da comunicação entre indivíduos, a linguagem simplifica e generaliza a experiência, ordenando as instâncias do mundo real em categorias conceituais cujo significado é compartilhado pelos usuários dessa linguagem”, o que possibilita os processos mentais de "abstração" e da "generalização" (OLIVEIRA, 2019, p. 40).

Nesta perspectiva, Oliveira (2019, p. 41), ao tratar do processo de formação de conceitos de Vygotsky, destaca que "os conceitos são construções culturais, internalizadas pelos indivíduos ao longo de seu processo de desenvolvimento”, e seu processo de formação percorre um "percurso genético” que consiste em três estágios:

i) “Formação de conjuntos sincréticos" - agrupamento de objetos de forma vaga e subjetiva;

ii) "Pensamento por complexos" - agrupamento de objetos de forma concreta e factual;

iii) "Formação de conceitos" - agrupamento de objetos com base em um atributo, de forma abstrata, sem a necessidade da experiência concreta. 
Segundo Oliveira (2019), tal percurso não é linear, porquanto o estágio dois e três ocorrem a partir de "duas raízes” independentes e se unem no estágio mais desenvolvido do processo em que se forma o conceito. Desta forma, enquanto o estágio dois estabelece diversas relações e organiza as impressões sobre uma determinada realidade concreta numa espécie de síntese do todo, forma uma base para o estágio três realizar processos de análise e abstração (OLIVEIRA, 2019).

Figura 11 - Ilustração com esquema sobre a Teoria Sociocultural de Vygostky

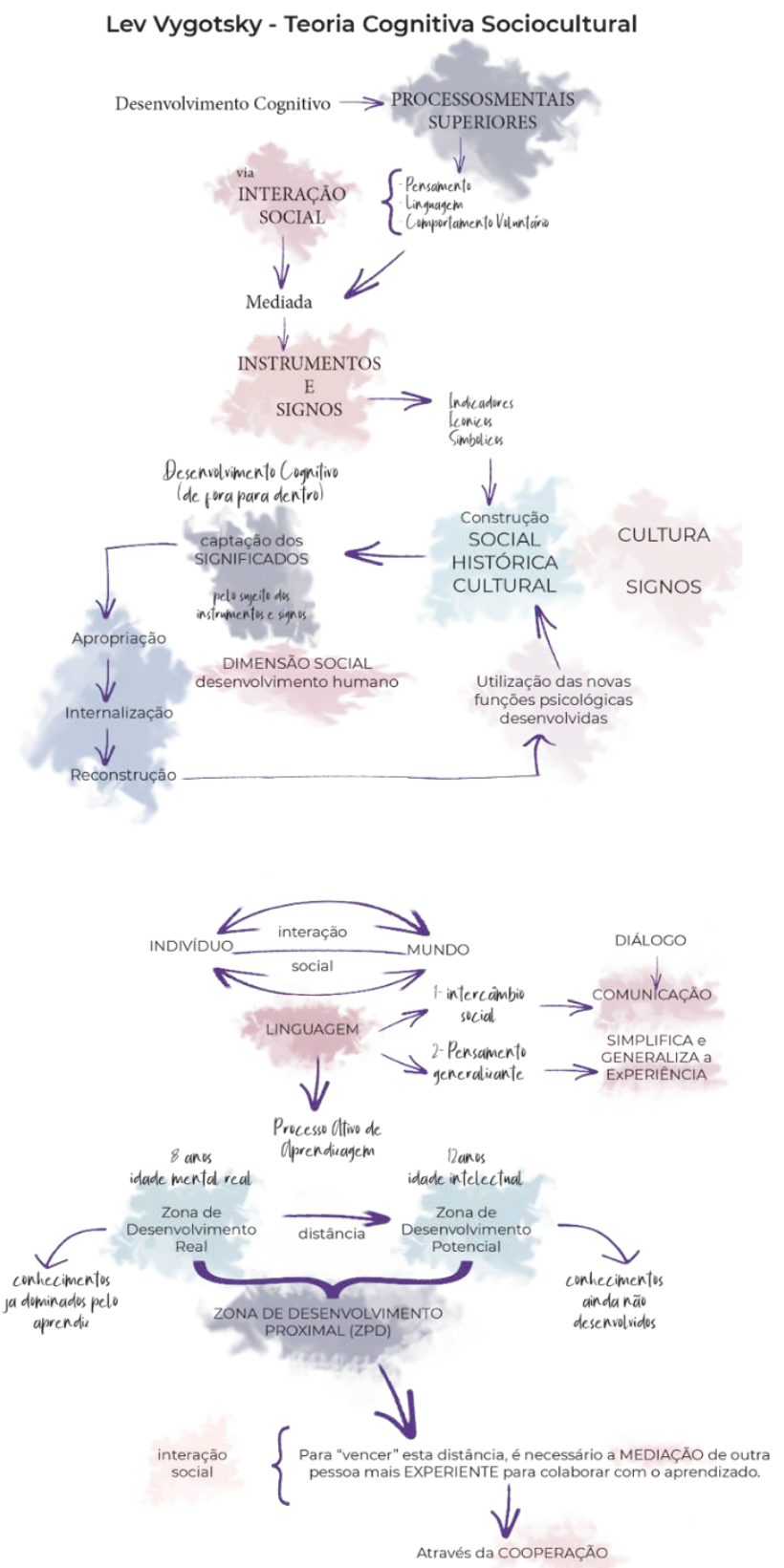

Fonte: idealização da autora, elaboração Camilla Ortega. 
Figura 12 - Ilustração com esquema sobre a formação de conceitos, em Vygostky

\section{Inteligencia - Conhecimento - Aprendizagem}

$$
\begin{aligned}
\text { Vygotsky } \longrightarrow & \text { Formação de Conceitos } \\
& \begin{array}{r}
\text { Construç̃es culturais } \\
\text { internalizaddas pelos } \\
\text { individuos }
\end{array} \\
& \left\{\begin{array}{r}
\text { Processo de Formação } \\
\text { PERCURSO GENÉTICO }
\end{array}\right.
\end{aligned}
$$
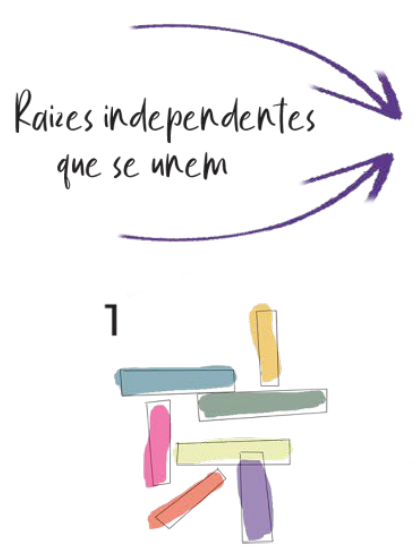

SUBJETIVAÇÃO
1 - Conjuntos Sincréticos

2 - Pensamentos por Complexos

3 - Formação de Conceitos

2

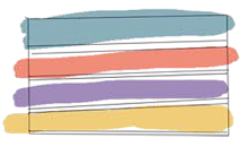

ORGANIZAÇÃO/ COMPREENSÃO DO TODO EXPERIENCIADO NA REALIDADE CONCRETA

SÍNTESE DO TODO

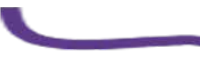

FORMAÇÃO DE CONCEITO

3 atributos de forma abstrata análise e abstracao concretae factual sintese do todo

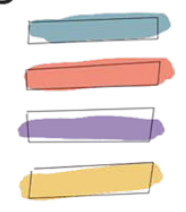

ANÁLISE E ABSTRAÇÃO

DA PARTE QUE COMPÕE O TODO
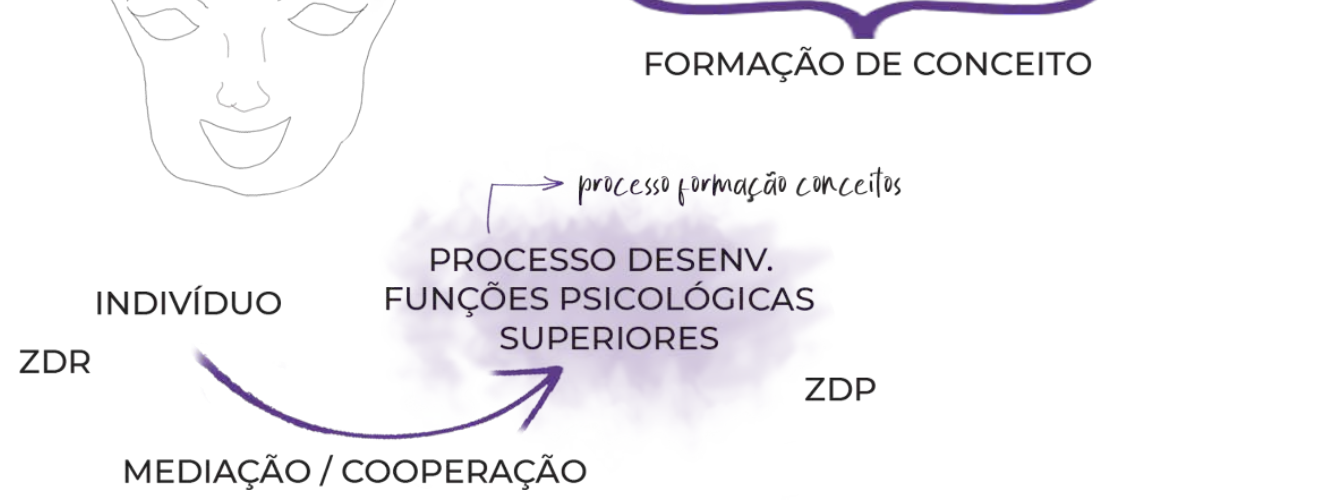

Fonte: idealização da autora, elaboração Camilla Ortega.

O “processo de desenvolvimento das funções psicológicas superiores”, mediado pela interação sociocultural, em que a companheiros mais experientes colaboram com o aprendizado 
potencial de outros companheiros menos experientes (ZPD), aproxima-se do que ocorre na ação cultural dialógica, no processo de síntese cultural, de Paulo Freire. Nas palavras deste autor:

[...] o saber mais apurado da liderança se refaz no conhecimento empírico que o povo tem, enquanto o deste ganha mais sentido no daquela. Isto tudo implica que, na síntese cultural, se resolve - e somente nela - a contradição entre a visão do mundo da liderança e a do povo, com o enriquecimento de ambos.

(FREIRE, 2018, p. 249)

Figura 13 - Ilustração com esquema da ação cultural dialógica, de Paulo Freire

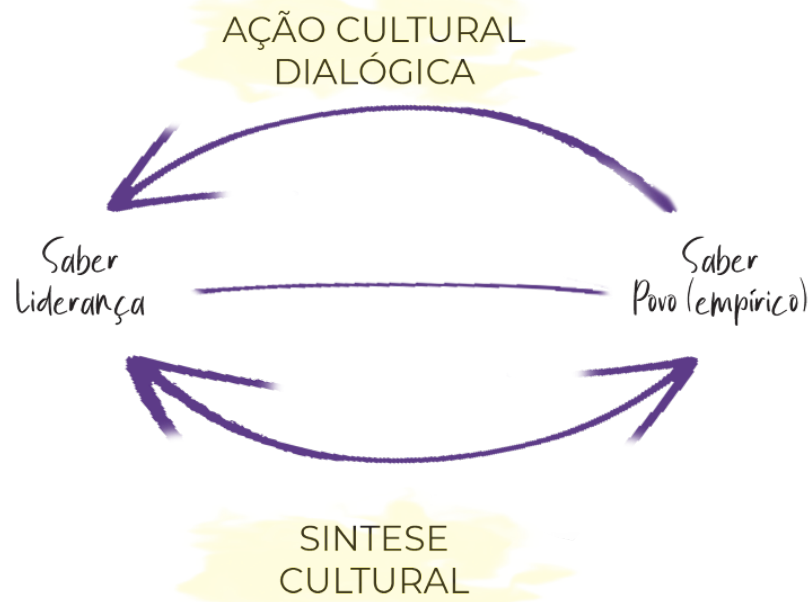

Fonte: idealização da autora, elaboração Camilla Ortega.

É importante destacar que o processo de formação de conceitos e o desenvolvimento dos “processos psicológicos superiores” estão intimamente ligados. Em vista disso, faço uma analogia do processo de formação de conceitos com os processos de territorialização (des-re) (TDR).

Na concepção apresentada de construções culturais, para Vygotsky, os conceitos seriam formados através de um percurso genético representado por estágios de agrupamento de objetos, inicialmente de forma vaga, passando por um agrupamento de objetos em torno de uma experiência concreta, até se chegar a uma atribuição abstrata desvinculada daquela experiência (OLIVEIRA, 2019, p. 41). A territorialização, definida pela "apropriação social de um fragmento do espaço a partir das relações sociais, regras e normas” e outros elementos que o 
compõem (SAQUET, 2015, p; 39), também ocorreria por meio de um processo similar de apropriação de significado a partir da experiência, ou da interação indivíduo-território.

Na medida em que o processo de TDR ocorre, a apropriação de significados e sistemas simbólicos vão sendo internalizados pelo indivíduo, possibilitando essa reestruturação da representação da totalidade por meio da aproximação e experimentação da nova realidade concreta. Tal processo permite fazer análises à medida que se aproxima e se afasta dos dados concretos e de suas representações, tendo em vista o afastamento que o indivíduo possuía antes de "interagir" com o território e seus códigos. Segundo Bassani et al. (2019), o território constitui-se como elemento formador e transformador do sujeito e a territorialização opera como instrumento pedagógico e político, na medida em que ressignifica a relação do sujeito com o território.

Figuras 14 - Ilustração com esquema da interação com o território e a apropriação de significados

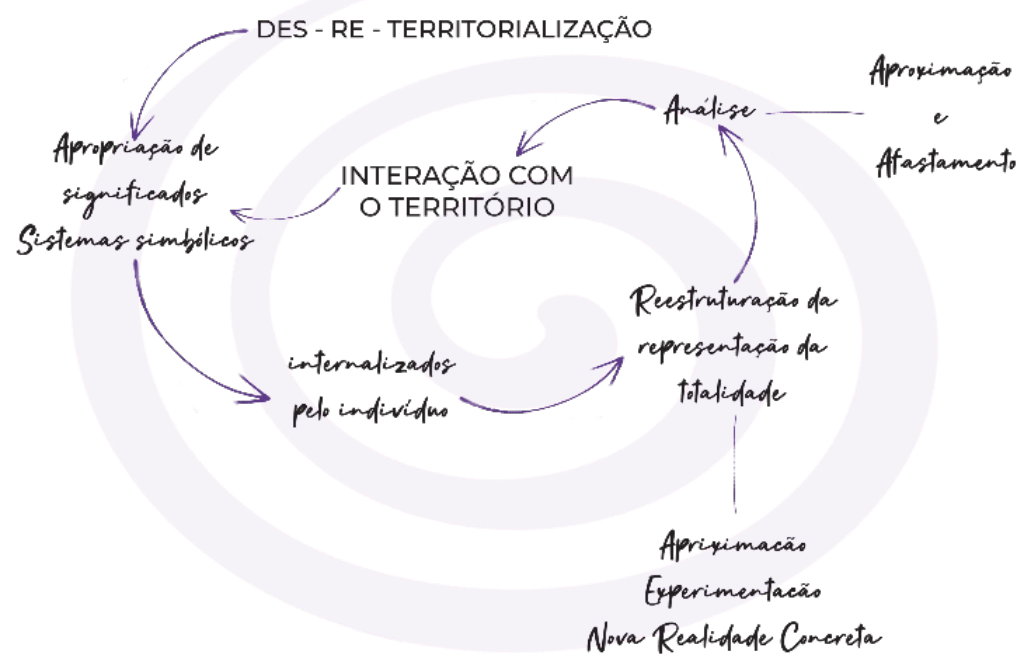

Fonte: idealização da autora, elaboração Camilla Ortega.

Segundo Oliveira (2019), a formulação de conceitos cotidianos (espontâneos) ocorre por meio das "interações sociais imediatas” do indivíduo, isto é, baseado em uma experiência concreta; enquanto que o processo de desenvolvimento de conceitos científicos inicia-se pela mediação verbal adquirida pela transmissão sistematizada do ensino escolar formal. Para Vygostky, ambos os processos ocorrem em direções contrárias porque se iniciam de maneiras diferentes, o primeiro de baixo para cima e o segundo de cima para baixo, sendo que a evolução 
de ambos é seu encontro (VYGOTSKY, 2001; OLIVEIRA, 2019). Esta união é um dos objetivos em projetos de extensão universitária territorializadas, cuja integração universidadesociedade possui potencial transformador.

Figura 15 - Ilustração com esquema sobre a territorialização das práticas educativas e a formação de conceitos, em Vygostky
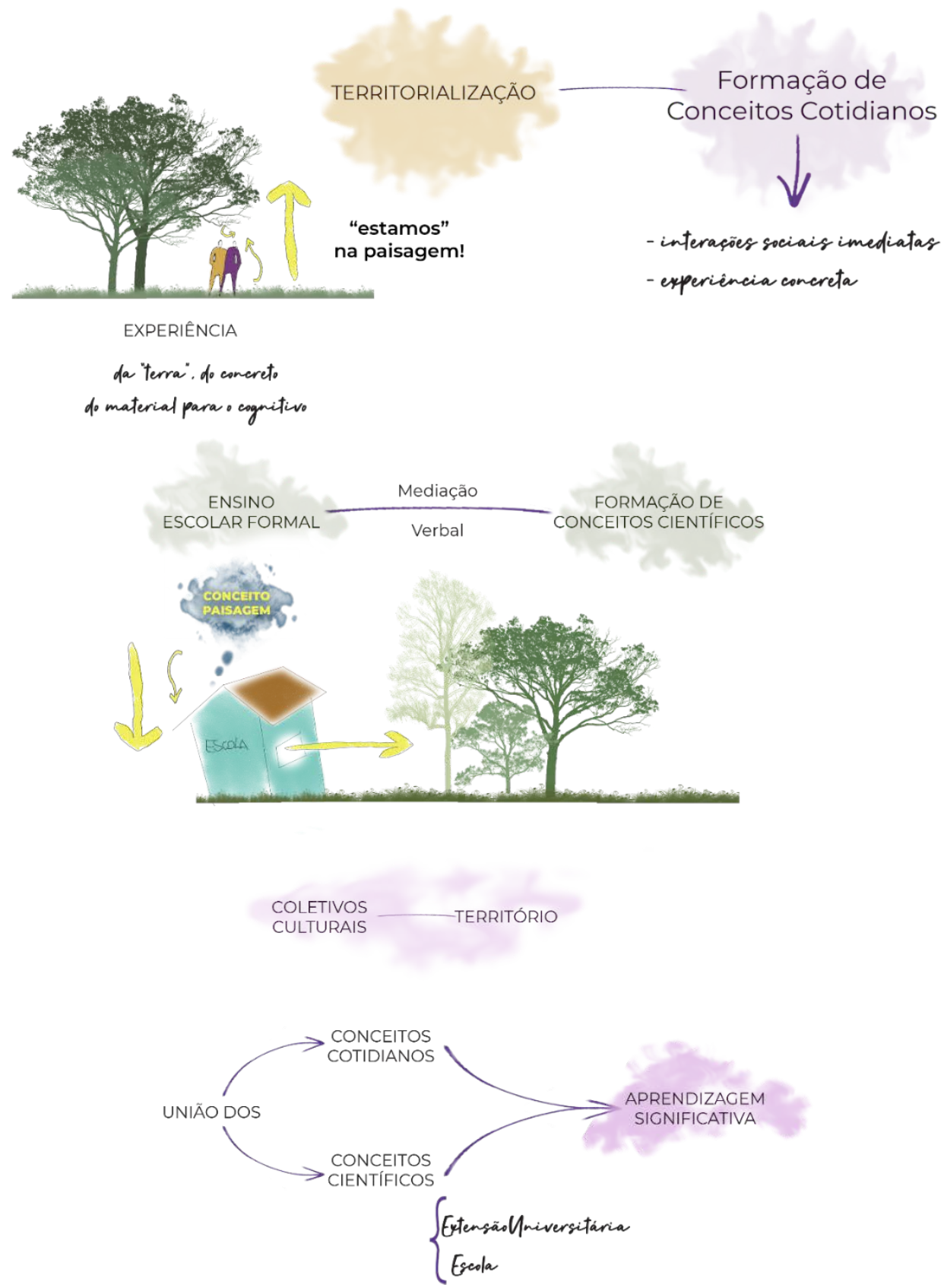

Fonte: idealização da autora, elaboração Camilla Ortega. 
Tão importante quanto o desenvolvimento cognitivo a partir da interação sociocultural é a busca por uma aprendizagem que correlacione “conceitos cotidianos/espontâneos” com “conceitos científicos”, tendo em vista de que o processo de formação deste último implica em “sistemas consistentes de inter-relações” e por ocorrer por mediações simbólicas, como a linguagem, implica em uma "atitude metacognitiva” (OLIVEIRA, 2019, p. 49). Ressalto a relação com a visão de Freire (1996) de que não existe uma ruptura, mas sim uma superação na passagem da "curiosidade ingênua”, associada ao senso comum, para a "curiosidade epistemológica”, associada ao saber crítico e metodologicamente construído, como o científico.

A compreensão da abordagem de Vygotsky sobre a formação de conceito e desenvolvimento cognitivo pela interação sociocultural é essencial para o presente trabalho, notadamente para análise que será realizada no capítulo três a respeito das práticas educativas verificadas nos territórios do Bororé e Perus.

\subsection{Educação formal, não-formal, popular, comunitária e social}

\subsubsection{O conceito de educação formal, não-formal e informal}

As definições de educação formal, não formal e informal dadas por Maria da Glória Gohn (2011), Moacir Gadotti (2012), Jaume Trilla (2008) e Philip Coombs \& Manzoor Ahmed (1974) se aproximam na medida em que consideram a primeira como uma educação escolar tradicional, a segunda realizada por vias alternativas, especialmente fora do âmbito escolar, e a terceira pela educação familiar e da cidade durante todo o processo de vida do indivíduo. Por sua vez, elas se afastam à medida que o objeto de estudo, o campo disciplinar e o contexto sociopolítico diferem uma da outra. Portanto, apresentarei a conceituação de educação nãoformal de Philip Coombs e Ahmed, referência no tema a partir da década de 1960, quando a difusão do termo começou a ocorrer de forma mais intensa. Em seguida, apresentarei a definição de Jaume Trilla (2008). E, por fim, as definições que mais se aproximam da visão desta pesquisa, por estarem vinculadas ao pensamento de Paulo Freire e à realidade brasileira, a partir das concepções de Maria da Glória Gohn (2011) e Moacir Gadotti (2012).

Para Coombs \& Ahmed (1974) o conceito de educação perpassa as fronteiras de tempo e espaço delimitadas pela escola, consistindo em um processo contínuo que ocorre através de métodos variados, desde a infância até a fase adulta, tripartida (mas não de forma estanque) entre educação formal, não-formal e informal. Deste modo, educação informal para estes 
autores consiste no "processo ao longo da vida pelo qual todas as pessoas adquirem e acumulam conhecimentos, habilidades, atitudes e ideias a partir de experiências diárias e exposição ao ambiente” (COOMBS \& AHMED, 1974, p. 8 - tradução nossa), com um aspecto importante a ser ressaltado: ocorre de modo “aleatório”, ou não sistematizado, incorporado ao processo de vida de qualquer indivíduo. Já a educação formal consiste no “'sistema educacional’ altamente institucionalizado, cronologicamente graduado e hierarquicamente estruturado, abrangendo a escola primária e os níveis mais altos da universidade” (COOMBS \& AHMED, 1974, p. 8 tradução nossa). Enquanto que a educação não-formal consiste em "qualquer atividade educacional organizada, sistemática e realizada fora da estrutura do sistema formal para fornecer tipos selecionados de aprendizado a subgrupos específicos da população, adultos e crianças” (COOMBS \& AHMED, 1974, p. 8 - tradução nossa). A educação tripartida conceituada por Philip Coombs e Manzoor Ahmed consiste na essência de que as outras concepções aqui abordadas irão se utilizar.

Figura 16 - Ilustração com a representação da educação formal (escolar)

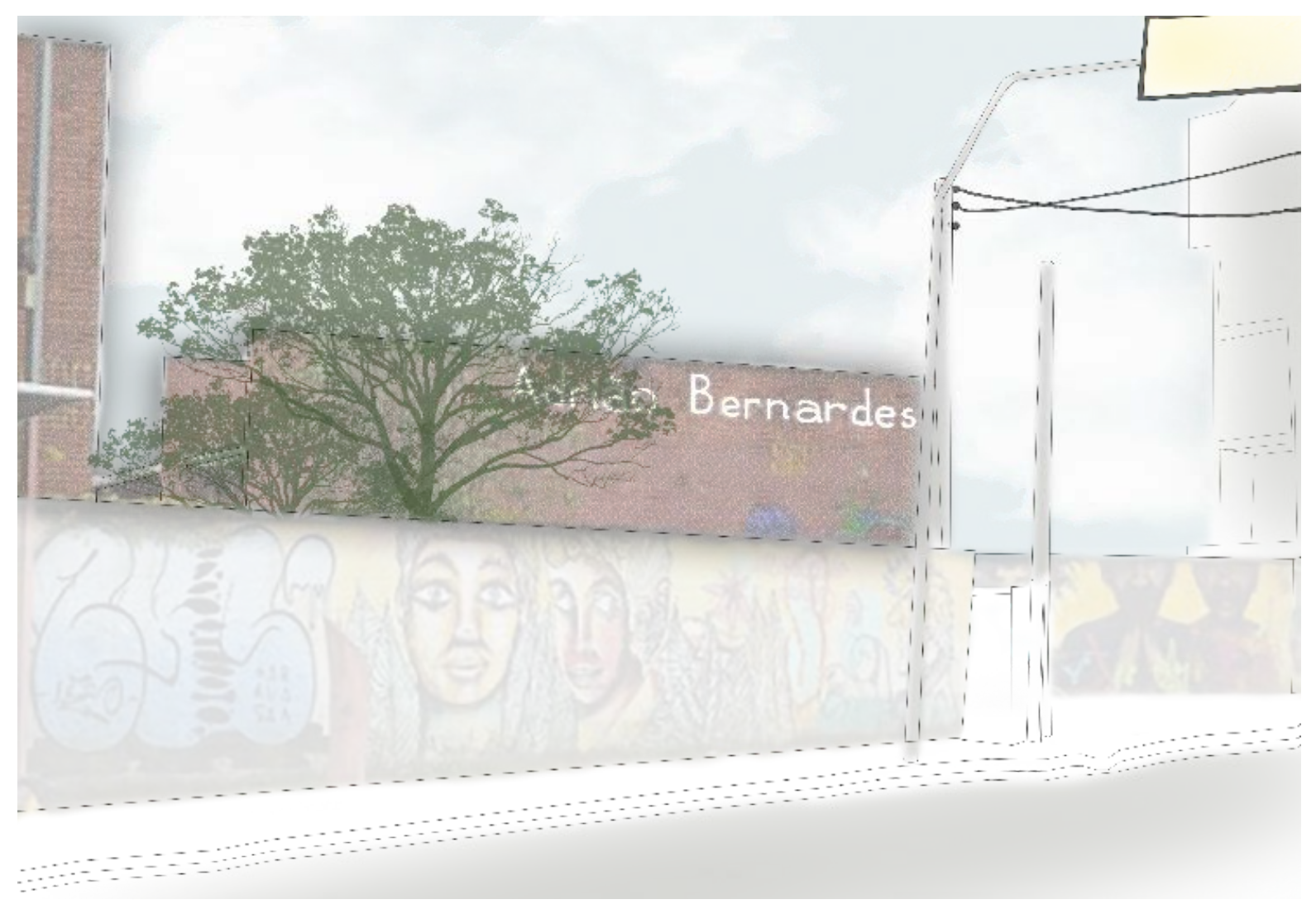

Fonte: idealização da autora, elaboração Camilla Ortega. 
Nesta perspectiva, Jaume Trilla (2008) aprofunda o debate e ressalta que se torna necessário classificar os tipos de educação a partir do estabelecimento de critérios específicos, como a etapa da vida a que se destina o ensino, ou ao efeito que ela pretende produzir, se estão vinculadas a alguma ideologia, o tipo de metodologia educacional que utilizam, ou ainda ao agente que a produz. Deste modo, a estrutura de tripartição do universo educacional proposta por Jaume Trilla (2008) consiste em classificar as educações formal e não-formal num mesmo tipo de educação, enquanto a educação informal se diferenciaria pelos critérios de especificidade e diferenciação do processo educacional pois, na visão do autor, os critérios de intencionalidade e método para se diferenciar as educações formal, não-formal da informal não definem um limite muito preciso por si só. A fronteira entre educação formal e não-formal sob os critérios metodológico e estrutural consiste no distanciamento tanto dos procedimentos quanto da estrutura educativa regrada, tradicionalmente incorporadas à instituição escolar. Do ponto de vista metodológico, a educação não-formal, devido à diversidade de lugares, grupos de pessoas e possibilidade de diversas formas de organização, abarca mais possibilidades de experimentar e adaptar diferentes metodologias educacionais, inclusive as utilizadas na escola tradicional, de acordo com às necessidades específicas a que pretende atender (TRILLA, 2008).

Para melhor delimitar o que se entende por educação não-formal, o critério estrutural é o mais indicado por Trilla (2008). Ele diz respeito ao aparato legal e administrativo nos quais a escola está circunscrita, a partir de seu contexto sociopolítico e histórico, ou seja, o sistema educativo regrado, o qual abarca os níveis de ensino da pré-escola ao universitário e confere graus e títulos acadêmicos. De acordo com o autor essa "relatividade histórica e política" confere certo dinamismo entre o formal e o não-formal, certa mobilidade e possibilidade de mudança de um para o outro a depender das forças que se estabelecem no contexto social e político de cada época (TRILLA, 2008).

Portanto, Trilla (2008, p. 42 - grifo nosso) define a educação não-formal como: “[...] o conjunto de processos, meios e instituições específica e diferencialmente concebidos em função dos objetivos explícitos de formação ou instrução não diretamente voltados à outorga dos graus próprios do sistema educacional regrado”. Em vista disso, o autor apresenta alguns âmbitos onde a educação não-formal pode se desenvolver, como formações ligadas ao trabalho, dentro de programas e práticas ligadas ao lazer e à cultura, no âmbito da educação social e, inclusive, dentro da própria escola a partir da integração de propostas e agentes provenientes do setor não formal. Assim como havia sido alertado por Coombs \& Ahmed (1974, p. 8) que a tripartição era apenas conceitual e que as educações "overlap and interaction between them" (que elas se 
sobrepõem e interagem entre si), Jaume Trilla (2008) também reconhece “interações funcionais” entre elas e identifica cinco possíveis formas de interação entre os três tipos de educação: i) "Relação de complementaridade”; ii) "Relação de suplência ou de substituição”; iii) "Relação de substituição"; iv) "Relação de reforço e colaboração"; v) "Relação de interferência ou contradição”.

Em vista disso, o ideal a ser perseguido no universo educacional seria a relação de complementaridade entre as três educações, o que implica na "partilha das funções, de objetivos, de conteúdos entre os diversos agentes educativos” (TRILLA, 2008, p. 46), embora seja perceptível no cotidiano a existência de um acúmulo de funções na instituição escolar, em detrimento de outras instâncias.

Para finalizar as concepções sobre educação não-formal na visão de Jaume Trilla (2008), alinho-me às suas ideias quando defende que um bom programa educacional deve resultar num “híbrido” entre a educação formal com a incorporação do setor não-formal e a valorização do informal, em que a relação de “complementaridade” constitua um sistema “aberto, flexível, evolutivo, rico em quantidade e diversidade de ofertas e meios educacionais” (TRILLA, 2008, p. 53). O enfoque dado à educação não-formal não reduz a importância da educação formal (pública, diga-se de passagem) no acesso ao ensino de qualidade, mas sim que se percebe a importância de se pensar meios que possam colaborar para um acesso mais amplo e democrático à educação, direito esse que ainda não foi atingido plenamente na sociedade brasileira.

No contexto brasileiro, Maria da Glória Gohn (2009) assinala que as práticas da educação não-formal estão em evidência no campo do "associativismo", especialmente por meio de atividades de grupos que questionam a forma tradicional e excludente da produção do saber científico, em detrimento da validação dos saberes populares provenientes do cotidiano. Para a autora, "a educação não-formal é uma área que o senso comum e a mídia usualmente não veem e não tratam como educação porque não são processos escolarizáveis” (GOHN, 2009, p. 31). Deste modo, Gohn (2009) compreende que a educação não-formal possui algumas dimensões como a “aprendizagem política” e cidadã dos indivíduos, a aprendizagem para o trabalho, aprendizagem para resolução de conflitos e “problemas coletivos do cotidiano”, seguindo alguns temas caros à cidadania como gênero, raça, juventude etc.

Nesta perspectiva, a maioria das práticas da educação não-formal acontece “extramuros” da escola, principalmente através da atuação de ONGs e movimentos sociais, em que os processos educativos ocorrem tanto através da ação cultural, educativa e artística, quanto da política (GOHN, 2009). Ademais, Gohn (2009) aponta para a ocorrência da educação não- 
formal no seio dos processos participativos, mesmo os institucionalizados, como os colegiados e conselhos gestores. De acordo com a autora, “a educação não-formal está muito associada à ideia de cultura” (GOHN, 1999 apud GOHN, 2009, p. 32), e se constitui um campo de “formação para a cidadania”, pois busca educar para a “justiça social”, para os "direitos humanos, sociais, políticos e culturais”, dentre outros (GOHN, 2009, p. 32).

Figura 17 - Ilustração com a representação da educação não-formal no âmbito da cultura, roda de dança com mestre em cultura popular

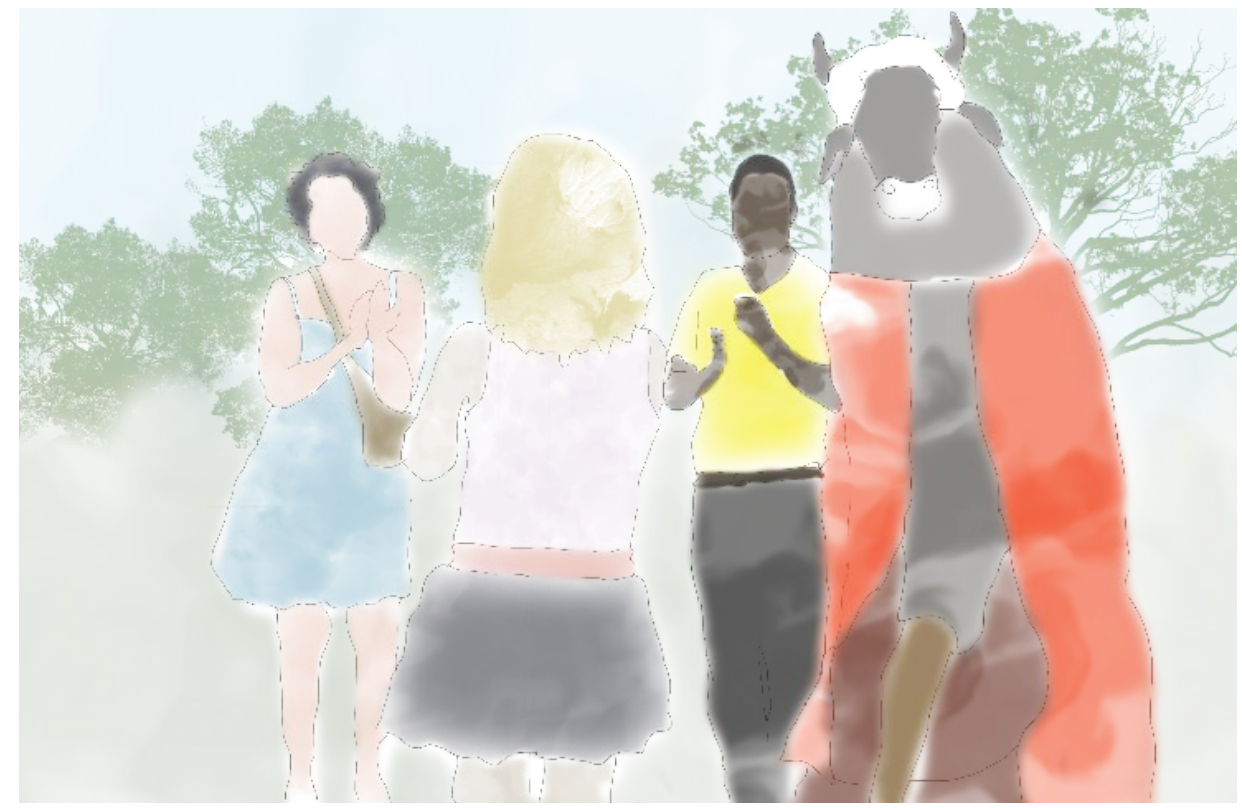

Fonte: idealização da autora, elaboração Camilla Ortega.

Figura 18 - Ilustração com a representação da educação não-formal no âmbito da cultura, o som dos tambores transmitindo valores da cultura ancestral africana

Fonte: idealização da autora, elaboração Camilla Ortega. 
Dentre estes eixos e em meio aos diferentes "tipos de lutas e movimentos na área da educação não-formal”, Gohn (2011, p. 351) apresenta alguns campos de atuação onde ocorrem “ações educativas de movimentos sociais, práticas civis e associativismo de ONGs”, como: i) “trabalho nos sindicatos”; ii) "trabalho com movimentos sociais populares”; iii) "trabalho na área de ação social comunitária”. Nesse contexto, ao analisar a relação entre os movimentos sociais e a educação não-formal, Gohn (2011, pp. 352-353) identifica doze "tipos de aprendizagens”, desenvolvidos por meio da experiência coletiva e do exercício da cultura, como a “aprendizagem prática”, a “teórica”, a “técnica instrumental”, a “política”, a “cultural”, a “linguística”, a econômica, a "simbólica”, a “social”, a “cognitiva”, a "reflexiva” e a "ética”. Devido à polissemia do termo “educação não-formal” e aos diferentes usos empregados, geralmente atrelados à educação de adultos, Gadotti (2012, pp. 14-15) apresenta algumas noções em relação às práticas e aos agentes, as quais são apresentadas resumidamente a seguir:

i) Educação formal: caracterizada pela estrutura das escolas e universidades, com currículo, hierarquia e regulamentação;

ii) Educação de adultos: termo difundido por organismos internacionais como a Unesco. Em alguns lugares reconhecida como “educação não-formal” para adultos, especialmente quando tratadas por países “desenvolvidos” para designar as práticas que ocorrem em "países em desenvolvimento”. No Brasil ela ocorre por meio do Estado após a II Guerra Mundial;

iii) Educação não-formal: desenvolveu-se em oposição à “educação oficial de adultos” onde não houve atendimento do Estado, por meio de ONGs, “movimentos sociais, partidos políticos, sindicatos, igrejas etc.”; é “mais difusa, menos hierárquica e menos burocrática”, um “conceito amplo, muitas vezes associado ao conceito de cultura” e à “aprendizagem política” individual e coletiva;

iv) Educação popular: desenvolveu-se, também, em oposição à “educação oficial de adultos” em espaços onde não houve atendimento do Estado, com o intento de criar uma “nova epistemologia” a partir da reflexão crítica sobre a "prática cotidiana”.

Para Gohn (2009, pp. 41-42), a educação não-formal constitui um “novo campo de ação coletiva”, com importância na "formação para a cidadania”, na “inclusão social” em 
“comunidades carentes socioeconomicamente”, na potencialização de processos de aprendizagem da educação básica quando desenvolvidos em complementaridade à educação formal, na "união de cultura e política”, proporcionando meios para a construção de uma nova “cultura política”. Ademais, Moacir Gadotti (2012) defende que não há uma barreira muito rígida entre educação formal e não-formal. Ele ressalta que geralmente os termos são colocados em oposição para sua compreensão, mas que o ideal é a análise das potencialidades da educação não-formal enquanto um "conceito amplo" que pode abarcar a educação social, popular e sociocomunitária, em vista de elas terem em comum a valorização de "espaços informais de aprendizagem".

Assim, alinho-me às abordagens de Maria da Glória Gohn e de Moacir Gadotti quando percebem a potencialidade das educações em complementaridade, notadamente da educação não formal como parte das práticas do associativismo, dos movimentos sociais e coletivos de cultura. É importante ressaltar a heterogeneidade de práticas e discursos nesse âmbito, sobretudo os cooptados pela visão de mercado e pouco comprometidos com a autonomia e conscientização dos sujeitos. Essa não é a prática, tampouco a abordagem que defendo e percebo nos coletivos com os quais tive contato durante a pesquisa.

\subsubsection{Educação popular, social e comunitária}

Muitas vezes a educação não-formal é confundida com a educação popular. Contudo, a educação popular possuía um interesse em formular uma nova epistemologia, não em apenas “agir por outras vias” que não a do Estado (GADOTTI, 2012). Neste sentido, a educação nãoformal pode se ocupar em ensino de língua estrangeira, por exemplo, não possuindo necessariamente caráter popular. Já a educação popular tem um componente essencial em sua prática educativa: a prática política, associada à organização das classes populares (TORRES, 1987 apud GADOTTI, 2012) ${ }^{39}$.

Segundo Gadotti (2012, p. 22), a educação popular nasce no seio de lutas populares com intuitos educativos e políticos, ou seja, de fortalecer as organizações populares, cuja gênese de seu paradigma teórico carrega um pouco do "anarquismo do proletariado industrial do início do século passado; o socialismo autogestionário; o liberalismo radical europeu; os movimentos populares; as utopias de independência (nacional-desenvolvimentismo); as teorias da libertação

\footnotetext{
39 Compreensão a partir dos trechos da entrevista de Paulo Freire concedida a Maria Rosa Torres no texto de Gadotti (2012, p. 24). Cf. TORRES, Rosa Maria (org.), 1987.
} 
e a pedagogia dialética”. O autor afirma que ela contribui com alternativas para a educação formal e deve se inserir no campo de disputa para se tornar uma política pública. Em vista disso, percebe-se a importância da educação popular na “formação de sujeitos sociopolíticos”, conforme apontado por Gohn (2009b). Importante destacar a compreensão da categoria de sujeito apresentada pela autora:

[...] constitui e posiciona indivíduos na história dos processos sociais, culturais e políticos de uma sociedade. A categoria sujeito confere protagonismo e ativismo aos indivíduos e grupos sociais, transforma-os de atores sociais, políticos e culturais, em agentes conscientes de seu tempo, de sua história, de sua identidade, de seu papel como ser humano, político, social.

(GOHN, 2009b, p. 18 - grifo nosso)

Ao tomar como base o Centro Ecumênico de Documentação e Informação (CEDI, 1993 $)^{40}$, Gohn (2009b, p. 19) elenca algumas questões centrais de tal paradigma como: a “valorização da cultura popular”, da “ética e da democracia”, a valorização do contexto de vida e cotidiano do educando nos processos pedagógicos, o ensino por uma ótica de pesquisa e investigação, “a relação entre conhecimento e politização”, e entre “educação e movimentos sociais” e em todos os processos o diálogo como fator central.

A autora compreende ainda a íntima relação entre o pensamento de Paulo Freire e a educação popular, sobretudo pela criação de seu “método” de “alfabetização de jovens e adultos da área rural”, que consiste em uma educação que conscientiza o sujeito de si e do mundo, para nele atuar e transformar (GOHN, 2009b, p. 20). O método de alfabetização, também conhecido por "método de conscientização", ocorria por meio de três etapas: i) investigação de temas chaves presentes na realidade do aluno; ii) "tematização", através da compreensão do “significado social” de tais temas; iii) “problematização”, através da construção de uma leitura crítica (GOHN, 2009b, p. 20). Na visão da autora, a questão nevrálgica e de maior importância na proposta elaborada por Freire consiste no "diálogo" e na importância dada aos "processos comunicativos”, considerados de vanguarda para a década de 1960, bem como a mudança na relação educador-educando com a perspectiva de conferir autonomia ao educando nos processos educativos (GOHN, 2009b). Nas palavras de Freire (2018, p. 228): “a co-laboração, como característica da ação dialógica, que não pode dar-se a não ser entre sujeitos, ainda que

\footnotetext{
${ }^{40}$ Cf. em Tempo e Presença, n. 272. CEDI- Centro Ecumênico de Documentação e Informação,1993.
} 
tenham níveis distintos de função, portanto, de responsabilidade, somente pode realizar-se na comunicação. O diálogo, que é sempre comunicação, funda a co-laboração”.

A “conscientização”, na perspectiva freireana, consiste em um processo que acontece da ingenuidade para a "tomada de consciência”, seguida da “ação reflexiva”, ou seja, da “práxis” (GOHN, 2009b, pp. 21-22). De acordo com a autora, a educação popular é vista como um movimento de "subversão discreta”, que tem como objetivo a garantir a conquista da capacidade de "organização, participação e conscientização" (GOHN, 2009b, p. 23). Nas palavras de Freire: “a organização das massas populares em classe é o processo no qual a liderança revolucionária, tão proibida quanto estas, de dizer sua palavra, instaura o aprendizado da pronúncia do mundo, aprendizado verdadeiro, por isto, dialógico” (FREIRE, 2018, p. 243, grifo do autor). Portanto, educação popular seria aquela ligada a processos de formação de consciência e organização políticas.

Já a educação comunitária, segundo Gadotti (2012, p. 18), “pode ser entendida como uma das expressões da educação popular, mediante a qual se busca melhorar a qualidade de vida dos setores excluídos, através dos movimentos populares, que estão organizados em grupos de base, comunidades, municípios etc.”. Apesar da variedade de experiências de “educações comunitárias”, há um fator comum entre todas que é o da constituição de processos coletivos relacionados à educação fora no âmbito da educação formal (GADOTTI, 2012). Já a educação popular comunitária (GADOTTI \& GUTIÉRREZ, 1993 apud GADOTTI 2012) carrega os princípios da conscientização e organização da educação popular difundida por Freire na década de 1960, e a partir da década de 1980 agrega a noção do associativo e do produtivo enquanto compreensão de seus processos como pedagógicos. A esse respeito, Gadotti (2012) acrescenta que a educação comunitária tem sido verificada, sobretudo, em comunidades mais pobres, onde os laços de solidariedade são mais fortalecidos e a necessidade de organização contra a discriminação é maior. Portanto, a educação comunitária apresenta uma significativa dimensão territorial. 
Figura 19 - Ilustração com a representação da educação comunitária, no âmbito da cultura, no programa Ecoativa Férias

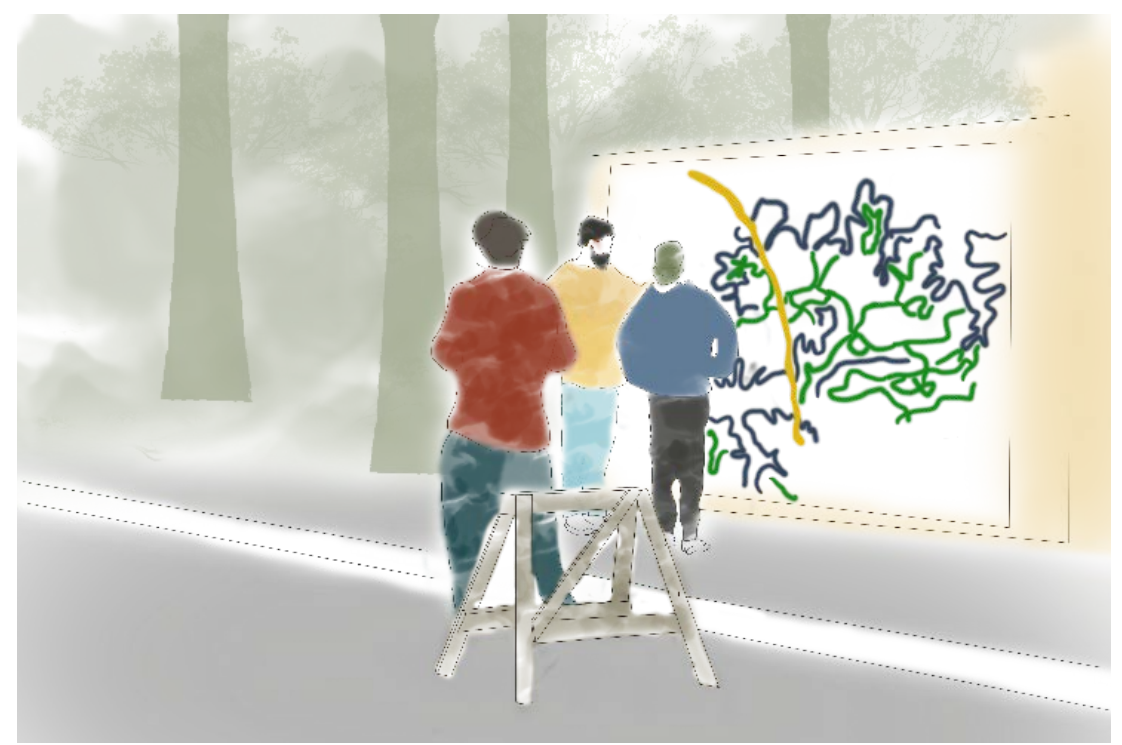

Fonte: idealização da autora, elaboração Camilla Ortega.

Em relação ao campo de atuação da educação social no Brasil, Gadotti (2012) afirma que ele possui tradição a partir da práxis da educação popular, em grande parte fora do contexto escolar. A educação social, na visão do autor, seria aquela voltada à educação do indivíduo no que se refere aos seus direitos e deveres com relação aos problemas sociais que o rodeiam. Seria, assim, a educação exercida para transformação da realidade social, o qual pode se dar tanto dentro da educação formal como na educação não-formal, a despeito de a maior parte das práticas ser verificada no âmbito não escolar. O autor destaca que a educação social - ou educações sociais - engloba todos os tipos de educação (formal, informal, não-formal, a educação popular, cidadã, comunitária etc.), pois defende que toda educação deve ser social, já que envolve a sociedade em que está inserida. Portanto, a educação social é exercida tanto em espaços formais como não formais (GADOTTI, 2012).

Apesar de atuarem num mesmo campo pedagógico, as referidas educações por vezes se aproximam mais nos temas e menos nos locais de atuação e formas de organização, tendo como ponto central a luta por conquista de direitos e a diversidade, sob um compromisso éticopolítico de transformação social (GADOTTI, 2012). As práticas comuns nas três educações popular, social e comunitária -, estão pautadas, historicamente, pela luta por direitos democráticos e pela atuação de diversos profissionais provenientes de periferias urbanas e espaços públicos degradados com sujeitos de todas as gerações. Em visto disso, Gadotti (2012) 
ressalta que as três educações nasceram da prática social, relacionadas ao compromisso de atuar em contextos compostos por grupos socialmente vulneráveis. Ademais, vale registrar que as educações popular, comunitária e social vêm ganhando força na sociedade brasileira e no debate acadêmico, em contraponto ao modelo educacional excludente neoliberal, em que o Estado se coloca como colaborador dentro de uma lógica competitiva de aferição dos rankings internacionais, como o PISA, que revela uma "política que exclui, classifica e pune os setores populares” (GADOTTI, 2012, p. 10).

Figura 20 - Ilustração com a representação da educação social, no âmbito da cultura e do meio ambiente

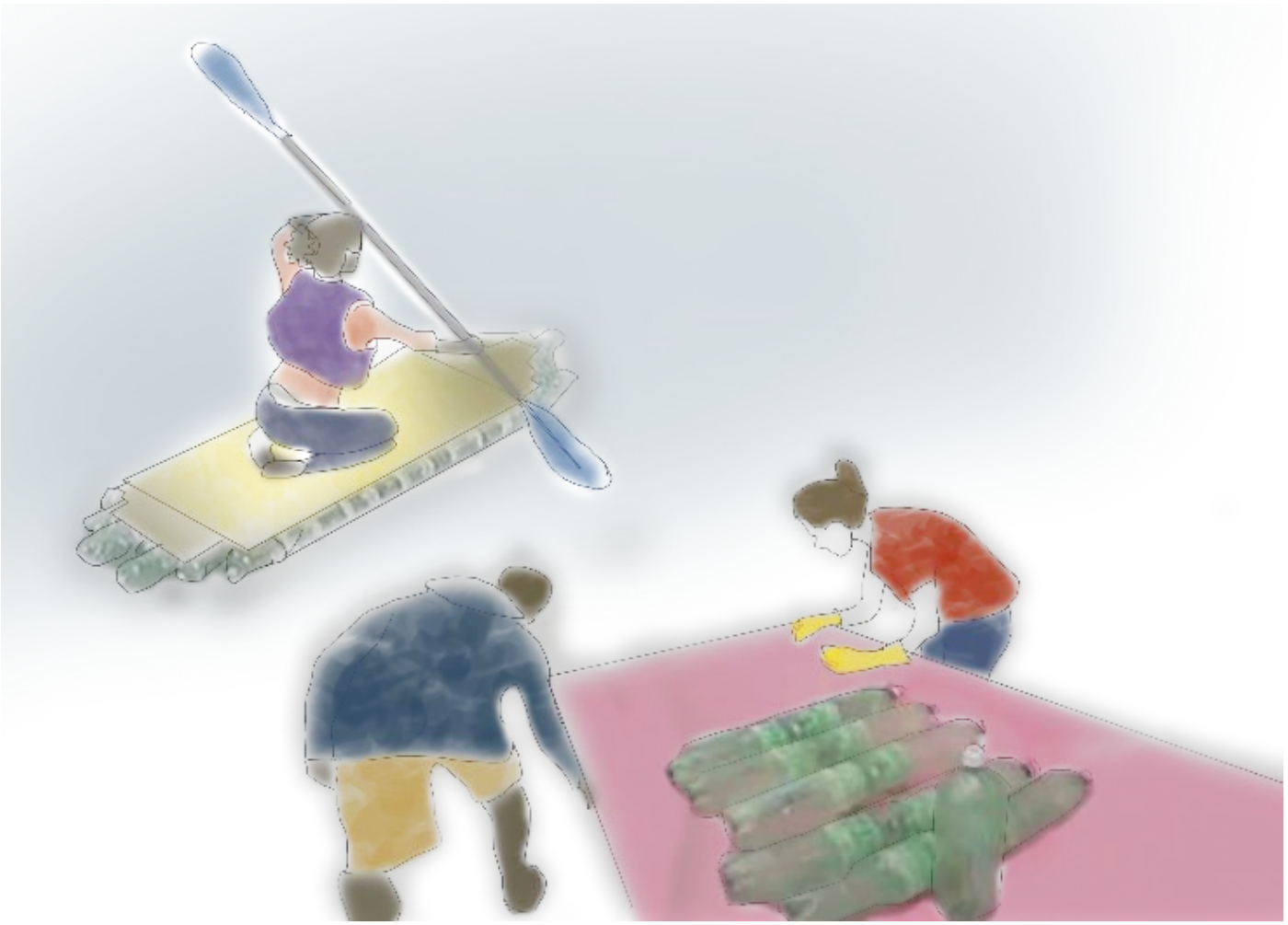

Fonte: idealização da autora, elaboração Camilla Ortega, com base em imagem do Navegando nas Artes. Disponível em: https://www.navegandonasartes.com.br/. Acesso em: 25 fev. 2021. 
Figura 21 - Ilustração com a representação da educação social, no âmbito do lazer e meio ambiente, na Represa Billings - São Paulo/SP

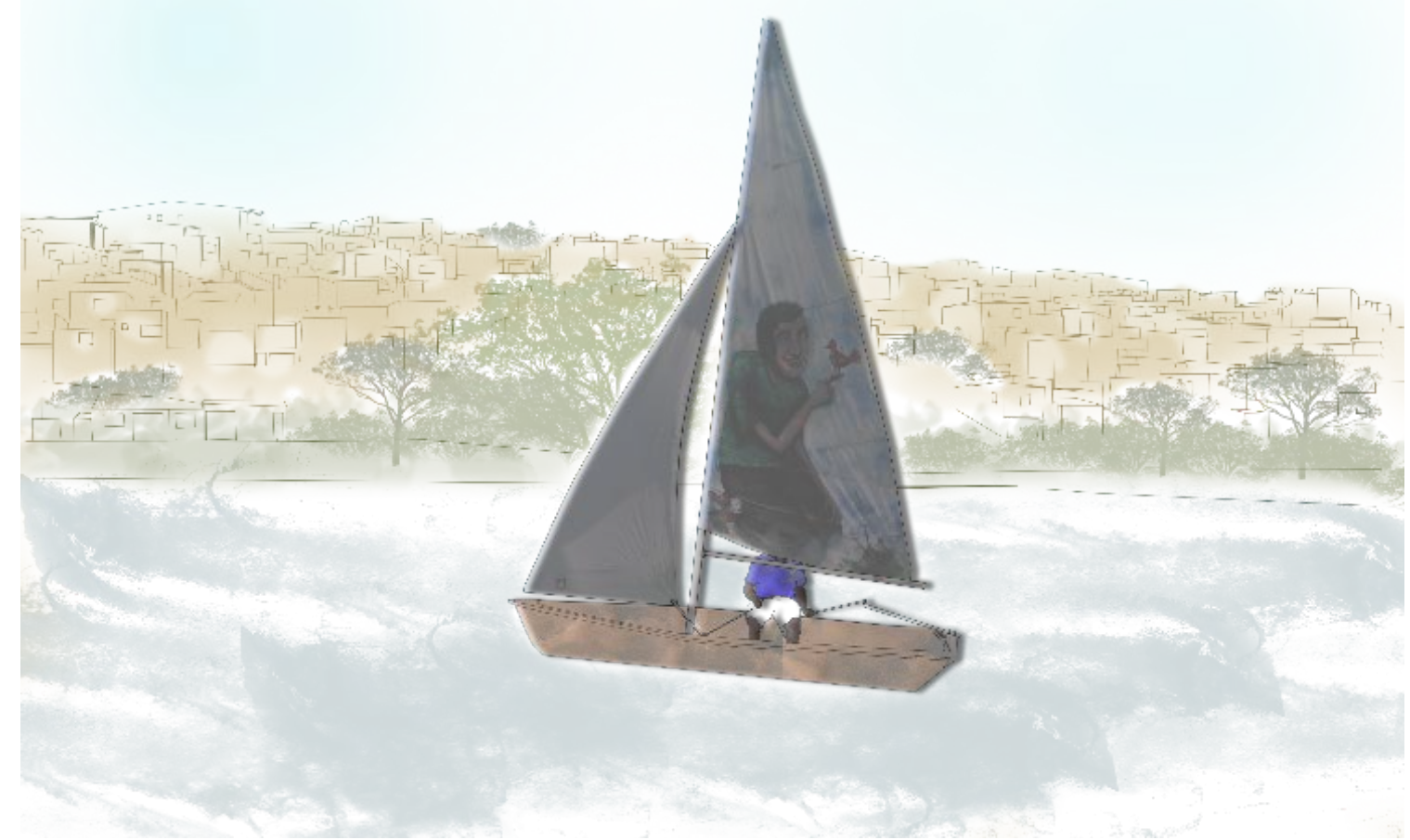

Fonte: idealização da autora, elaboração Camilla Ortega, com base em imagem do Navegando nas Artes. Disponível em: https://www.navegandonasartes.com.br/. Acesso em: 25 fev. 2021.

Figura 22 - Ilustração com a representação da educação social, no âmbito da cultura

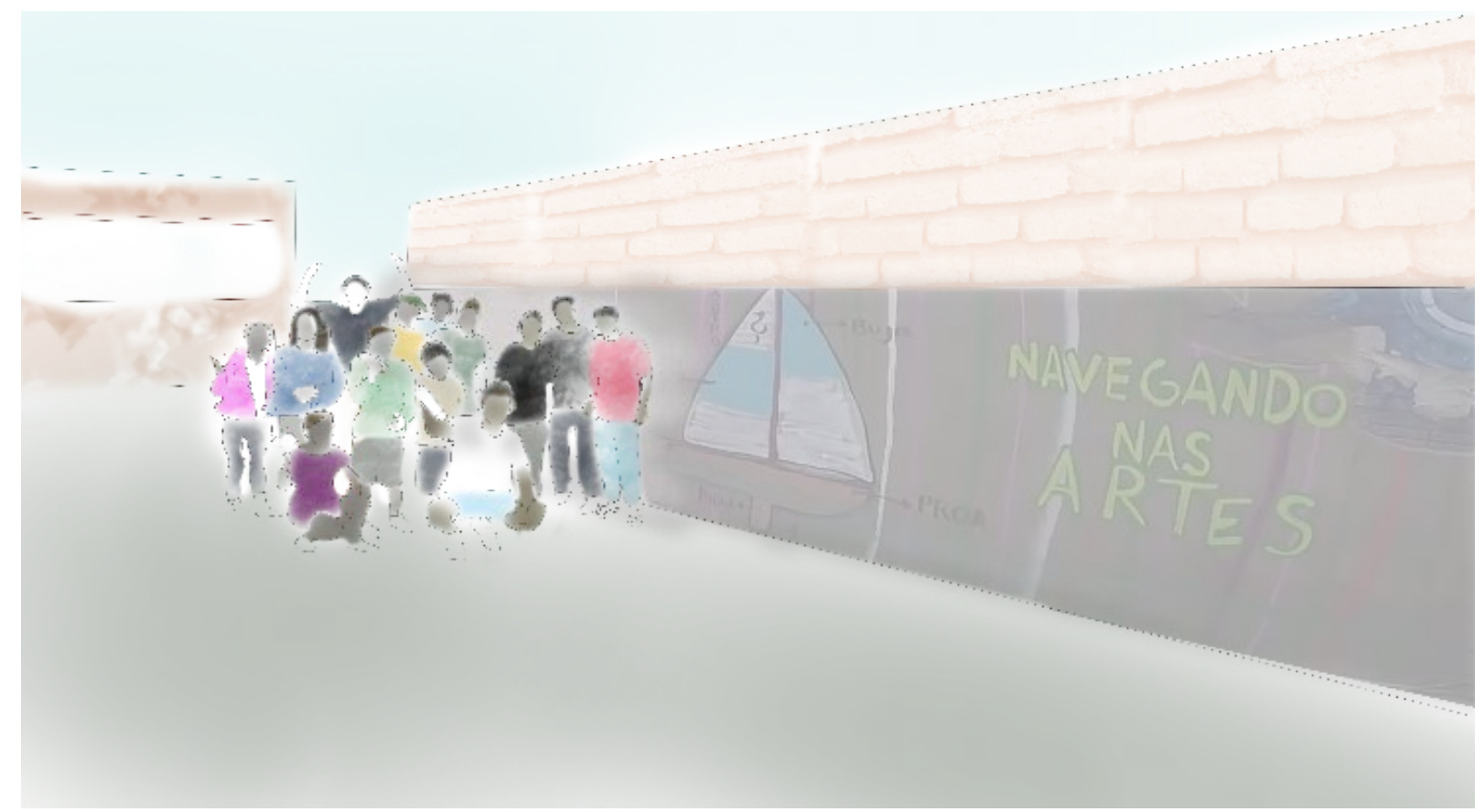

Fonte: idealização da autora, elaboração Camilla Ortega, com base em imagem do Navegando nas Artes. Disponível em: https://www.navegandonasartes.com.br/. Acesso em: 25 fev. 2021. 
Portanto, a educação pode ser classificada de diversas maneiras, entre elas: escolar, formal, não formal, informal, popular, social, comunitária. A pluralidade de classificações para o termo leva a um questionamento: por que nomeamos? Ou ainda, por que (re)nomeamos? O processo de dar nome a algo concreto, de conferir significações está diretamente ligado aos sistemas simbólicos que fazem parte da sociedade, como abordado anteriormente com os estudos de Vygotsky. Nomear uma prática que já possui uma nomenclatura pode apontar para um sintoma de que a definição “dada” não representa algumas práticas de determinados grupo sociais. Nesse sentido, Moacir Gadotti reproduz uma máxima, com a qual concordo, de que “toda educação deveria ser social”, pois envolve a sociedade em que está inserida. Isto posto, cabe-nos refletir em que medida a educação tem servido a um projeto de sociedade justa, democrática e de formação de cidadãos conscientes e autônomos, bem como em que medida os discursos e as práticas se contradizem ou não. Tal reflexão se alinha ao pensamento de Paulo Freire.

Segundo Gohn (2009b, pp. 25-28), Paulo Freire dedicou-se a pensar temas como a “cidadania”, a “solidariedade”, a “subjetividade”, a “dimensão cultural nos processos de transformação social” e educativos, a "ética” e a “cultura da diversidade”, a preocupação com o meio ambiente através da proposta de uma “ecopedagogia”, bem como o papel da escola de formar "cidadãos de uma sociedade planetária”, conscientes de seu papel e inserção local, como no mundo, além da abertura crítica ao uso de novas tecnologias nos processos educativos. Para Paulo Freire (1996), a “prática educativo-progressista” deve se desenvolver em favor da autonomia do ser, a partir do pressuposto da "inconclusão do homem” e de seu ponto de vista a partir dos “condenados da Terra”. Ademais, a responsabilidade ética que envolve a prática educativa insere-se sob a ideia de uma “ética universal do ser humano”; ela opõe-se à “ideologia fatalista” (e imobilizante) do neoliberalismo e declara sua posição na História e seu "mover-se no mundo” pela perspectiva de que o “futuro é problemático e não inexorável”, portanto os seres são condicionados, mas não determinados (FREIRE, 1996).

O legado de Paulo Freire é algo tão valioso, quanto simples e intuitivo: aprende-se fazendo, aprende-se a partir do próprio universo do educando, trabalhando-se o pensamento e a linguagem em comunhão com a atitude das mãos, dos processos, do ir e vir, do "mover-se no mundo” e compreender-se no mundo: “a educação problematizadora se faz, assim, um esforço permanente através do qual os homens vão percebendo, criticamente, como estão sendo no mundo com que e em que se acham” (FREIRE, 2018, p. 100). Neste sentido, aprende-se 
comunicando, falando e, principalmente, ouvindo, praticando a alteridade e a dialogicidade, sem perder de vista a energia responsável por constituir mudanças políticas e sociais.

Ademais, a educação que se busca deve respeitar a identidade cultural dos educandos e assumir a solidariedade social e política como fundamentais para uma formação democrática. Para o presente trabalho, valoriza-se tanto a(s) educações sociais (GADOTTI, 2012), bem como a "rigorosidade metódica" do ensinar, quanto à flexibilidade criativa do experimentar defendidas por Freire (1996). Assim como Freire, valoriza-se a importância das relações estabelecidas nos interstícios dos tempos e espaços escolares, bem como a "pedagogicidade indiscutível na materialidade do espaço”:

Se fosse claro para nós que foi aprendendo que percebemos ser possível ensinar, teríamos entendido com facilidade a importância das experiências informais nas ruas, nas praças, no trabalho, nas salas de aula das escolas, nos pátios dos recreios, em que variados gestos de alunos, de pessoal administrativo, de pessoal docente se cruzam cheios de significação.

(FREIRE, 1996, p. 19 - grifo nosso).

O fato de me perceber no mundo, com o mundo e com os outros me põe em uma posição em face do mundo que não é de quem não tem nada a ver com ele. Afinal, minha presença no mundo não é a de quem a ele se adapta mas a de quem nele se insere. É a posição de quem luta para não ser apenas objeto, mas sujeito também da História.

(FREIRE, 1996, p. 22 - grifo nosso).

Por fim, Gadotti (2012) afirma que o pensamento de Paulo Freire incide na educação popular, social e comunitária por meio das seguintes contribuições:

1. Teorizar a prática para transformá-la. A prática como base para gerar pensamento. Os sujeitos populares como protagonistas do seu próprio aprendizado e atores de sua emancipação.

2. O reconhecimento da legitimidade do saber popular, da cultura do povo, suas crenças, numa época de extremado elitismo (academicismo sem prática social).

3. Um método de ensino e pesquisa que parte da leitura da realidade (leitura do mundo), da observação participante. Parte do concreto, o mundo vivido dos sujeitos e setores populares. Ensino-aprendizagem inseparável da pesquisa, da cultura popular e da participação da comunidade. 
4. Uma teoria crítica do conhecimento, fundamentada numa antropologia (ser humano inacabado, incompleto, inconcluso): somos programados para aprender. Importância das condições de aprendizagem: ênfase nos processos e não nos resultados.

5. Uma educação como prática da liberdade, precondição para a vida democrática: educação como produção e não meramente como transmissão de conhecimentos; a educação como ato dialógico (recusa do autoritarismo), ao mesmo tempo rigoroso e imaginativo.

6. Uma ciência aberta às necessidades populares: a relevância social como critério de qualidade da ciência.

7. Harmonização entre o formal e não-formal. O direito à educação não é apenas direito de ir à escola, mas direito de aprender na escola e ter acesso a oportunidades de educação não formal (cinema, teatro, esporte, cultura, lazer...).

8. A utopia como verdadeiro realismo do educador, opondo-se ao fatalismo neoliberal que nega o sonho de outro mundo possível.

9. A educação como direito humano, direito de se emancipar, combinando trabalho intelectual com trabalho manual, reflexão e ação, teoria e prática, conscientização e transformação, a organização, o trabalho e a renda (economia popular solidária).

(GADOTTI, 2012, p. 23 - grifo nosso).

Tais concepções serão importantes para a análise das práticas verificadas nos territórios do Bororé e Perus, como será visto no capítulo 03.

\subsubsection{A crítica ao sistema educacional formal e a emergência de práticas e discursos de educação não-formal}

A educação formal é relativamente nova na sociedade, datando aproximadamente 250 anos, se considerada a partir dos critérios de seleção e certificação para atender a um "mercado de profissões” que cresceram com a urbanização do continente europeu (GHANEM, 2008). Nesse contexto, Elie Ghanem (2008) situa dois momentos importantes em relação à recente história da educação formal, o primeiro a partir do século XVIII, quando a educação escolar tinha uma finalidade política, que buscava formar uma cidadania moderna pautada na razão e na liberdade, e o segundo em meados do século XIX, quando a educação escolar começou a servir a uma função econômica. Posteriormente, a escolarização de massas, em meados do século XX sob o bojo do Estado de bem-estar social, teve como promessa o acesso igualitário, democrático e integral à educação; contudo, a percepção de que apenas o acesso à educação 
formal sanaria a desigualdade começou a se desfalecer, notadamente a partir dos anos 1960. É importante situar que essas transformações ocorreram em torno de um século antes na Europa do que no Brasil.

Neste contexto, pensar as questões sociais, políticas, econômicas e culturais do século XX implica pensar as profundas marcas deixadas na humanidade após a Segunda Guerra Mundial. Dentre as importantes transformações que ocorreram, uma foi a expansão do sistema universitário mundial, como ressalta Wallerstein, ([s.d.]), a partir da expansão da "economiamundo" atrelada a tendências democráticas. Nesse contexto, a década de 1960 foi paradigmática nas ciências, como abordado no primeiro capítulo. Segundo Thiollent (1998), na área da educação, as pautas por uma reforma estudantil deixaram heranças como os estudos da didática e da pedagogia vinculadas à sua dimensão política e ao questionamento da dimensão classista da universidade, com reflexões acerca de uma universidade popular que se vinculasse à prática e ao contexto de vida dos trabalhadores.

Nesse momento, houve também uma intensificação dos discursos pedagógicos em torno da educação não-formal e a busca por sua integração e legitimação, pautados pela percepção de que a instituição educacional formal já não poderia mais ser o lugar exclusivo da educação (TRILLA, 2008). A partir disso, emergem reações ao ensino formal sob quatro aspectos: i) o “discurso reformista da crise educacional”; ii) as "críticas radicais à instituição escolar”; iii) a "formulação de novos conceitos"; iv) o "paradigma do meio educacional” (TRILLA, 2008). Desse modo, Trilla (2008) considera que publicações ${ }^{41}$ como "A crise mundial da educação" $(1968)^{42}$, “Aprender a ser: a educação do futuro” (1972) ${ }^{43}$ influenciaram a emergência dos “discursos tecnocrático-reformistas" e das “críticas radicais” à instituição escolar em decorrência do enorme desencanto em relação à educação escolar de massas. O discurso reformista, pautado na modernização, fundamentou-se em densos diagnósticos sobre o estado da educação no mundo; todavia não apresentavam críticas aos contextos sociopolíticos e econômicos engendrados (TRILLA, 2008).

Paralelamente, segundo Trilla (2008), a crítica radical à escola de massas levantou o que a abordagem tecnocrática reformista anterior não trazia: a identificação dos vínculos entre educação, política, sociedade e economia. A denúncia do “paradigma da reprodução”, bem como a teoria da desescolarização e da perspectiva foucaultiana, relacionada à microfísica do

\footnotetext{
41 Trilla (2008) ressalta também o reflexo da publicação da UNESCO - Educação - um tesouro a descobrir $(1996)^{41}$ - em discursos, práticas e políticas durante a década de 1990.

${ }^{42}$ Publicação original: COOMBS, P. H., The world educational crisis. Nova York: Oxford University Press, 1968.

${ }^{43}$ Publicação original: FAURE, E. et al., . Apprendre à être. UNESCO: Paris, 1972.
} 
poder, foram amplamente apropriadas pelo campo da educação e se tornaram referenciais teóricos no campo no final do século XX (TRILLA, 2008; COLLET \& SUBIRATS, 2016).

O informe da UNESCO elaborado por Edgar Faure, em $1972^{44}$, traz algumas questões sobre o aumento dos custos mundiais relativos à educação durante a década de 1960, devido à expansão da escola de massas, do combate ao analfabetismo adulto, aliados às questões relativas à explosão demográfica e ao desemprego crescente. A análise da conjuntura parecia apontar para a dificuldade dos sistemas formais (e das economias) em arcar com toda a demanda social à época, realçadas no relatório pelo paradigma da época do desenvolvimento categorizado em países de Primeiro, Segundo e Terceiro Mundo. A partir disso, o cenário que se constituiu assentou as bases para o discurso que pretendia ver fora da escola a solução para os problemas apresentados neste período, ampliando, desta forma, o campo de atuação da educação não-formal (TRILLA, 2008). Surge, a partir desse contexto, a ideia de "educação permanente” surge, junto a uma multiplicidade de conceitos, e a sugestão de que a educação aconteça ao longo de toda a vida do sujeito, o que representa a “extensão temporal e espacial” da possibilidade de se educar para além da escola.

Por consecuencia, se ha demostrado que la empresa educativa no será eficaz, justa y humana sino al precio de transformaciones radicales que afectan a la sustancia del acto educativo, del espacio educativo y del tiempo de la educación, en una palabra, avalan el concepto de educación permanente.

(FAURE et al., 1973, p. 219 - grifo nosso)

Esse “duplo desdobramento da educação" (temporal e espacial), segundo Collet \& Subirats (2016), aponta para a constituição da semente que conecta os conceitos de território e educação. Segunda Trilla (2008), é neste contexto que surgem diversos conceitos relacionados à ideia de "extensão de tempo", como formação contínua de adultos e “educação ao longo da vida”, por exemplo. O mesmo se deu com conceitos que surgiram em torno da ideia de “extensão espacial”, como “educação aberta, extraescolar, educação não-formal, sociedade educativa, cidade educadora” etc.

Pela ótica vigente à época, a ação educativa desprezava o “meio educacional” em que ocorria, bem como a influência que ele provocava sobre a ação e sobre o educando, além da influência que o educador provocava no meio educacional (TRILLA, 2008). Assim, novos

\footnotetext{
${ }^{44}$ Edição em castelhano utilizada para a consulta: FAURE, E. et al. Aprender a ser: la educación del futuro. Versión española de Carmen Paredes de Castro. - Alianza/UNESCO: Madrid, 1973.
} 
paradigmas começaram a ser pensados, pautados em estudos que trouxessem fundamentação teórica e prática, como a noção de “contexto”, que começa a ser tratada em meados do século XX, especialmente pela Sociologia da Educação, no âmbito de pesquisas sobre os contextos educacionais e a influência no sucesso acadêmico, enquanto a relação mais explícita e conceitual que aproxima escola e território ocorreu a partir da década de 1980 (CHAMPOLLION, 2015).

Pierre Champollion dedica-se a estudar a relação entre educação e território, notadamente a relação entre os "efeitos" dos "contextos territoriais" sobre a educação. Ele ressalta que as escolas rurais sempre mantiveram algum tipo de relação com o território em suas práticas educativas, e que, a partir de estudos ${ }^{45}$ dedicados a medir a sua eficiência, houve avanços em relação à temática da "contextualização territorial da escola” (CHAMPOLLION, 2015). Ademais, o autor destaca diversas experiências que surgiram com intuito de integrar a escola ao seu território, como o "uso pedagógico do entorno" que começou a ser aplicado na Itália, Espanha e França para dar sentido ao aprendizado; o “uso pedagógico de recursos locais”; o "partido territorial” de professores no Chile, na Espanha, França e Uruguai; a oferta de treinamento "pluriativo" na França, que é adaptado às ofertas sazonais de empregos voltados ao turismo (CHAMPOLLION, 2015).

A partir disso, Champollion (2015, pp. 14-15) categoriza três dimensões sobre a noção de “contexto”, de acordo com as áreas e as épocas em que alguns estudos se constituíram:

1) “Dimensão espacial” - a partir do campo da geografia houve uma aproximação conceitual, especialmente a partir das décadas de 1950 e1960;

2) “Dimensão sociológica” (social) - relaciona-se com os estudos do "contexto educacional” e o reflexo no "sucesso acadêmico", notadamente utilizada a partir da década de 1960 e 1970; estudos sobre currículos escolares e os dados socioeconômicos e territoriais das famílias dos estudantes e a correlação no sucesso acadêmico;

3) “Dimensão política do contexto educacional” - estudos sobre as "políticas educacionais territorializadas” relacionados à dimensão da educação com a finalidade de "medir e identificar" o "impacto no sucesso acadêmico".

\footnotetext{
45 Estudos realizados na França para medir a eficiência das escolas rurais em áreas de montanha: “Avaliação e direção prospectiva” (DEP) organizado pelo Ministério da Educação Nacional da França (MENE), sobre a eficiência das escolas rurais, além da uma publicação chamada Journal of Alpine Research, dedicada a "crianças que moram em uma área montanhosa ... seu futuro?” (CHAMPOLLION, 2015).
} 
Champollion (2015, pp. 15-16) afirma que “o território” tem sido aos poucos reconhecido pela Ciência da Educação, de forma que a criação da "Educação Relacionada ao Meio Ambiente" (ERE, em francês) e da "Educação para o Desenvolvimento Sustentável” (EDD, em francês), tem contemplado, através de "projetos territoriais”, o território como um "fator de impacto na escola" e no "processo educacional".

Uma questão importante a ser tratada, apesar de não ser o foco da pesquisa, consiste no desenvolvimento da educação rural enquanto prática que aproxima o processo educativo do território. Além das publicações supracitadas que influenciaram a crítica ao sistema educacional formal, houve também uma publicação importante de Philip Coomb e Manzoor Ahmed em 1974, intitulada “Attacking rural poverty: how nonformal education can help” (COOMB; AHMED, 1975). O teor do documento consistia em um relatório de pesquisa para o Banco Mundial, encomendado para sustentar programas de emprego e aumento de produtividade agrícola em países em desenvolvimento. Além de conceituar os três tipos de educação (formal, não-formal e informal), o estudo consistiu em analisar 25 programas de educação não-formal em países da Ásia, África e América Latina ${ }^{46}$. O estudo encomendado pelo Banco Mundial, que teve também como financiador a Fundação Ford, contou com parceiros como Unesco, Unicef, Organização das Nações Unidas para Alimentação e Agricultura (FAO) etc., e reflete a preocupação central que os organismos internacionais se concentraram em debater: a contenção do êxodo rural através da fixação do camponês no campo.

Ao analisar a influência do debate internacional sobre educação rural na realidade brasileira durante as décadas de 1960/70, Macioniro Filho (2019) realiza uma pesquisa documental sobre as concepções elaboradas pela UNESCO, OEA e CEPAL. De acordo com o autor, os estudos relacionados entre educação e êxodo rural tinham uma abordagem antes da Segunda Guerra Mundial e após 1945 ganharam um forte aspecto desenvolvimentista, especialmente pelos organismos internacionais, assessorados por economistas, cujos projetos de educação rural em países subdesenvolvidos visavam a modernização do campo, o aumento da produtividade agrícola e a consequente fixação do trabalhador rural naquele meio. $\mathrm{Na}$ América Latina, a visão de educadores nos debates da UNESCO, OEA e da CEPAL, em oposição aos economistas da primeira e em diálogo com os da segunda e terceira, fez-se

${ }^{46}$ Afeganistão, Colômbia, Etiópia, Índia, Indonésia, Quênia, República da Coreia, Malauí, México, Nigéria, Filipinas, Senegal, Tanzânia, Tailândia e Alto Volta. Cf. COOMBS, P.; AHMED, 1975. 
presente na década de 1960. Neste contexto, a perspectiva da OEA trouxe ao debate a questão da distribuição de terra, de renda e de serviços, evidenciando um caráter político e educativo mais explícito que o tratado pelos economistas da UNESCO (FILHO, 2019).

Outra perspectiva importante acerca da educação rural, no cenário brasileiro, insere-se no âmbito da educação popular, baseada no método de alfabetização de jovens e adultos do campo criado por Paulo Freire.

Segundo Gadotti (2012), a constituição da educação popular na Europa estava associada ao movimento anarquista na Espanha, no período anterior à Segunda Guerra Mundial; na América Latina, até 1950, ela se enquadrava na luta pelo acesso e pela gratuidade da escola pública, especialmente nas zonas rurais; e no final década de 1950 percebiam-se duas tendências no campo da educação popular: i) educação libertadora; ii) educação profissional, sob ideais de independência e desenvolvimento nacional, respectivamente (WANDERLEY, 1984 apud GADOTTI, 2012).

No Brasil, Carlos Brandão (2006) destaca que a primeira experiência verificada essencialmente a partir da classe popular foi o movimento encabeçado pelos operários imigrantes europeus anarquistas e comunistas, que trabalhavam principalmente nas indústrias de São Paulo e Rio de Janeiro. Esses operários foram responsáveis pela criação de escolas para os seus filhos, a qual exercia uma educação com relevante dimensão política. Por outro lado, os movimentos de erradicação ao analfabetismo e a luta pela ampliação do acesso à escola pública eram permeados pela presença do Estado e de movimentos da sociedade civil. Neste contexto, o autor identifica, entre 1920 e 1940, a existência desses três exemplos de trabalhos pedagógicos envolvendo a educação popular: (i) educação popular para as classes populares, consistente na luta pela escola pública, gratuita e laica; (ii) com as classes populares, atinente ao combate ao analfabetismo; e (iii) das classes populares, com relação às experiências de educação envolvendo operários.

De acordo com Gohn (2009b, p. 19), o “paradigma” da educação popular, no Brasil, tem base nos "Movimentos de Educação de Base e Cultura Popular, no final dos anos de 1950 e início dos anos 1960”. A autora apresenta um panorama de práticas que estabelecem uma “relação entre movimentos sociais e educação” (GOHN, 2011), a partir dos anos 1960 com as Ligas Camponesas e com os movimentos estudantis de “maio de 1968”, bem como da formação política de integrantes de movimentos sociais pelas Comunidades de Base da Igreja Católica (CEBs), na década de 1970, por meio da luta por infraestrutura urbana nas periferias de grandes cidades, até os “trabalhos de educação popular” na década de 1980, com a Constituição Federal 
de 1988, que promove uma nova “cultura política” na população (GOHN, 2011). Desse modo, segundo a autora, houve a construção de uma relação entre movimento social e educação quando a atuação dos atores sociais se deslocou do eixo fábrica-trabalho para as periferias urbanas, com pautas e demandas sobre infraestrutura e melhores condições de vida (GOHN, 2011).

Os anos 1970 e 1980 foram marcados pelo o endurecimento dos regimes militares, como também pela organização de grupos de oposição e resistência, formados pela Igreja Católica, movimentos sociais, sindicatos, ONGs e partidos políticos progressistas. Neste contexto, a educação popular passa a existir na forma da educação não-formal (BRANDÃO, 1982 apud GADOTTI, 2012) por meio da atuação dos grupos de resistência, em oposição à educação escolar; a partir de meados da década de 1980, com a redemocratização do país, o protagonismo das ONGS tem início por meio de parcerias com o Estado; também nesse momento instaurouse a “Escola Pública Popular” em São Paulo, na ocasião da atuação de Paulo Freire na Secretaria de Educação (GADOTTI, 2012). Nesta perspectiva, Maria da Glória Gohn (2000) destaca algumas práticas interessantes, como as escolas de assentamentos rurais públicas e as organizadas pelo Movimento dos Sem-Terra (MST), ao final da década de 1980 e 1990. A partir da década de 1990 houve o surgimento de diversas experiências para o campo da educação popular com a união de lutas políticas e lutas pedagógicas, o que segundo Gohn confere uma identidade aos movimentos sociais profundamente ligada à educação popular (GOHN, 2009 apud GADOTTI, 2012).

[...] a área da educação - devido ao potencial dos processos educativos e pedagógicos para o desenvolvimento de formas de sociabilidade, constituição e ampliação de cultura política, passou a ser área estratégica também para os movimentos populares, a exemplo do MST, no Brasil (GOHN, 2011, p. 340 - grifo nosso).

Apesar da “atualidade de Paulo Freire”, como afirma Gohn (2009b), a autora alerta para as mudanças ocorridas no modo como seu método tem perpassado as práticas da educação popular, a partir dos anos 1990. Segundo a autora, as décadas de 1970 e 1980 promoveram o surgimento de "métodos participativos" e de "trabalho de campo", a intensa mobilização de movimentos sociais populares em resistência à ditadura militar, tanto no Brasil como na América Latina e, portanto, a educação popular tinha um caráter eminentemente “sociopolítico”, o “educador popular” advinha de "lutas” e "militância” e os processos de 
conscientização buscavam uma transformação estrutural de problemas que atingiam as camadas mais oprimidas (GOHN, 2009b, p. 29-36).

Com a mudança no caráter das políticas públicas na década de 1990, aproximando-se de uma lógica neoliberal, Gohn (2011) afirma que houve um protagonismo das ONGs em detrimento dos movimentos sociais, bem como o surgimento de diversos movimentos culturais de jovens, com manifestações artísticas relacionadas ao hip hop e ao rap, com reflexos na educação popular. Nesse contexto, a autora destaca três movimentos sociais importantes no Brasil, como o movimento “dos indígenas, dos funcionários públicos - especialmente das áreas da educação e da saúde - e dos ecologistas”, este último impulsionado pela Eco-92 (GOHN, 2011, p. 343). Neste sentido, Gohn (2009b) destaca que conceitos e práticas foram sendo redefinidos por lógicas menos coletivas e mais individualistas e, deste modo, o processo de conscientização, que antes possuía um cunho político e questionador, agora passa a ser mais individual, psicológico e emocional, na busca por mudanças no comportamento do indivíduo. Outra característica que sofreu transformação a partir dos anos 1990, apontada por Gohn (2009b, pp. 31-33), trata-se da metodologia de trabalho, relacionada à natureza das instituições que promovem propostas de intervenções sociais (ONGs e entidades do terceiro setor) e que, muitas vezes, operam numa lógica empresarial.

Tal contexto neoliberal, a sua influência na universidade pública e a relação com a extensão universitária são abordados por Boaventura Sousa Santos, como passa a ser explorado no tópico seguinte.

\subsection{Para além dos muros da universidade: em busca de uma extensão universitária transformadora}

O significado de extensão universitária vem se alterando ao longo das décadas, diante dos avanços legislativos ocorridos, bem como de seu amadurecimento como ferramenta alternativa à pesquisa universitária convencional. Por outro lado, o avanço neoliberal provocou certo enfraquecimento da produção de conhecimento crítico e do viés social da extensão universitária ao estimular a proliferação de práticas alinhadas a um discurso voltado ao mercado. Neste tópico, além de um quadro histórico, serão apresentadas as críticas feitas por Paulo Freire à terminologia, as diferentes concepções de extensão universitária e aquela que se adotou no presente trabalho, bem como a importância da prática da extensão no enfrentamento 
da crise de legitimidade experimentada pela Universidade Pública, na visão de Boaventura de Sousa Santos, e a correlação existente entre a leitura do autor e a visão freireana.

A extensão universitária teve início na Inglaterra no século XIX (NOGUEIRA, 2005 apud GADOTTI, 2017) ${ }^{47}$ no âmbito da educação para adultos sem instrução escolar formal. Segundo De Paula (2013 apud BRITTO, 2017), a extensão universitária na Europa foi inicialmente associada à educação informal, porquanto buscava controlar os conflitos provenientes do modo de produção capitalista industrial nas áreas miseráveis que gerou. Britto (2017) ${ }^{48}$ afirma que no âmbito da América Latina, as universidades desempenharam um papel histórico à serviço da elite socioeconômica, e que, portanto, a defesa por sua função social, com a aproximação da classe trabalhadora e do movimento operário, ocorreu no seio da Reforma Universitária em 1918 e dos movimentos revolucionários de esquerda no início do século XX. No Brasil, o Decreto n ${ }^{0} 19.851$ de 1931, que determinava as bases do sistema universitário brasileiro, já relacionava o termo ao ensino superior. Todavia, apenas a partir da década de 1960 a extensão passa a ser associada a uma função social por parte da universidade em relação às classes populares, sob influência da ação de movimentos sociais e da criação do Serviço de Extensão Cultural, dirigido pelo educador Paulo Freire, em Recife (BRITTO, 2017; GADOTTI, 2017).

A partir de 1964, com a Ditadura Militar, muitos processos de educação popular são interrompidos. Em 1968 ocorreu a Reforma Universitária ${ }^{49}$, em que a relação da universidade com a comunidade deveria ocorrer sob o formato de cursos e prestação de serviços. Segundo Brandão (1982 apud GADOTTI, 2017), a educação popular voltou a influenciar a extensão universitária no final da década de 1970 e 1980, devido à intensa atuação dos movimentos populares.

A partir do momento em que a extensão passa a se vincular a uma função social da universidade, Paulo Freire (1983) assinala uma crítica à sua terminologia. Isto porque o termo extensão indica transmissão, prolongamento de algo, o que não se alinha com sua concepção de educação pautada na comunicação, no diálogo e na autonomia dos sujeitos. De fato, a teoria da ação dialógica formulada por Freire (2018) pressupõe a co-laboração, a união, a organização e a síntese cultural. A referida teoria implica em processos de comunicação entre os sujeitos e em métodos de conscientização que decodifiquem a realidade concreta e as

\footnotetext{
47 Disponível em https://www.paulofreire.org/images/pdfs/Extens\%C3\%A3o_Universit\%C3\%A1ria_Moacir_Gadotti_fevereiro_2017.pdf Acesso em 22 nov 2020.

${ }^{48}$ Cf. BRITTO, 2017. pp. 26-35.

${ }^{49}$ Lei 5.540/1968.
} 
relações sociais, históricas e culturais opressoras que as engendram. Freire (2018, pp. 146-147) argumenta que a ação cultural dialógica busca "superar as contradições antagônicas de que resulte a libertação dos homens” e seu objetivo maior é a síntese cultural, entendida como “a modalidade de ação com que, culturalmente, se fará frente à força da própria cultura, enquanto mantenedora das estruturas em que se forma”.

Com base nessa concepção, Freire (1983) afirma que toda ação carrega uma teoria subentendida, o que faria com que a extensão - como ato de estender, transmitir -, assim como a invasão cultural - oposto da síntese cultural -, estivesse circunscrita na teoria antidialógica da ação, o que não condiz com a prática educativa libertadora que defende. Nesse sentido, a “educação como prática de liberdade” consiste em uma "situação gnosiológica”, ou seja, os sujeitos aprendem em interação uns com os outros e por meio da mediação do mundo, comunicando-se através e com ele (FREIRE, 1983). Desse modo, o conhecimento e a educação libertadora implicam numa relação de comunicação, e não de extensão ou transmissão mecânica de conhecimentos. Assim, sendo o conhecimento fruto de um processo comunicativo e relacional entre os sujeitos e o mundo, a problematização dos conteúdos ocorre a partir da realidade concreta, da "compreensão dos signos significantes dos significados, por parte dos sujeitos interlocutores problematizados” (FREIRE, 1983, p. 56).

Posto isso, é fundamental assinalar o processo de conscientização dos sujeitos defendida pela proposta de educação libertadora de Freire (1981; 1983; 1996; 2018), através do confronto crítico com a realidade concreta e as relações em que nela ocorrem. Essa tomada de consciência, segundo o autor, ocorre através do exercício desafiador e intencional da "codificação pedagógica” da realidade vivida dos sujeitos, que por meio de sua representação e problematização criam-se condições de percebê-la criticamente. ${ }^{50}$

Freire criticava a terminologia por carregar um significado que traduz a ideia de transmissão de algo pela Universidade, o que denota certo distanciamento desta com relação à comunidade e aos saberes populares. Tal pensamento é fundamental para se compreender a leitura feita por Boaventura de Sousa Santos a respeito da Universidade Pública e a importância

\footnotetext{
50 Tal processo implica em quatro momentos: i) codificação da totalidade, consiste na representação de uma situação existencial vivida e implica na conscientização; ii) descrição dos elementos, ou das partes da totalidade; iii) distanciamento do sujeito para voltar-se ao todo com esse olhar "processado" pelo exercício pedagógico e simbólico; iv) análise crítica do sujeito, que após ter codificado e descodificado a situação poderá recodifica-la, portanto, transformá-la consciente e criticamente (FREIRE, 1981). Esse processo pedagógico que possibilita o desenvolvimento do pensamento crítico aproxima-se da abordagem de Vygostky (2001) sobre a formação de conceitos científicos, cujas fases de análise e síntese estão fortemente mediadas pelos símbolos e signos da cultura, como também mediadas por uma ação (pedagógica) de um companheiro mais experiente, como o (a) professor (a).
} 
da extensão universitária no início da década de 1990, época marcada pelas contradições decorrentes de um avanço democrático tensionado pelas pressões exercidas pelos processos de globalização e neoliberalização. Ilustro tal contradição no que se refere à extensão universitária.

Com a redemocratização do país, ocorre em 1987 a criação do Fórum de Pró-Reitores de Extensão das Universidades Públicas Brasileiras (FORPROEX) que propõe uma abordagem centrada na responsabilidade social das universidades e na defesa do ensino público. Em 1988 a extensão universitária adquire o status constitucional com a promulgação da Constituição Federal, que a prevê como um dos pilares do ensino superior (art. 207, CF/1988), no que se costuma denominar "princípio da indissociabilidade entre ensino, pesquisa e extensão”, tão aludido entre os defensores da extensão universitária. Vale ressaltar que o próprio artigo introdutório na seção correspondente à Educação na Constituição Federal de 1988 (art. 205, CF/1988) estabelece relação direta daquela com “exercício da cidadania” e à "preparação para o trabalho”, devendo ser a educação um “direito de todos” e dever da família, do Estado e da sociedade. A redemocratização do país e a Constituição Cidadã inscrevem-se em um momento em que um rol de práticas e discursos da sociedade estão alinhados com a democracia, com a cidadania, com a justiça social e com a dignidade da pessoa humana. No que se refere aos princípios do ensino, estabelecidos no artigo 206 da Constituição, tem-se a "igualdade”, a “liberdade”, o “pluralismo”, a "gratuidade”, a “gestão democrática”, a “qualidade”, a remuneração digna dos profissionais da educação por meio do salário mínimo e o "direito à educação” e à “aprendizagem ao longo da vida”. A partir desse momento ocorrem alguns avanços legislativos como a publicação da Lei de Diretrizes e Bases da Educação Nacional (LDB) em 1996, na qual a extensão universitária é prevista como uma finalidade da educação, bem como a publicação do Plano Nacional de Extensão (PNE), em 1999, da Política Nacional de Extensão Universitária, em 2012 e, mais recentemente, com a Resolução $\mathrm{n}^{\circ} 7$ (18 de dezembro de 2018), que estabelece as diretrizes para a Extensão Universitária na Educação Superior Brasileira, houve sua incorporação de um percentual mínimo à matriz curricular dos cursos de Instituições de Ensino Superior ${ }^{51}$.

\footnotetext{
${ }^{51}$ Apesar do avanço legislativo em propor relações dialógicas e transformadoras entre a universidade e a sociedade, a concepção da extensão universitária permanece no amplo espectro de práticas que vão desde i) programas, ii) projetos, iii) cursos e oficinas, iv) eventos, v) prestação de serviço (art. 8\%/Resolução nº7/2018). Portanto, devido à recente publicação e à heterogeneidade de práticas de diferentes naturezas no que concerne à extensão nesta Resolução, há ainda muito o que ser absorvido e compreendido a respeito dos possíveis reflexos no âmbito institucional, no que se refere ao cumprimento de carga horária e organização curricular, como no âmbito do ensino, da pesquisa e da extensão como atividade, de fato, formativa, dialógica e transformadora.
} 
Por outro lado, as transformações no plano macroeconômico e político foram influenciadas pela neoliberalização das políticas que incidiriam sobre a cidade. Algumas questões já foram apresentadas no capítulo e nas seções anteriores a respeito da década de 1990 e seus reflexos nas grandes cidades, como o aumento da desigualdade e violência, e nas formas de organização social, com a desmobilização de movimentos sociais e a privatização de espaços e serviços públicos. Como afirma Boaventura de Sousa Santos (2005), no âmbito da universidade pública, a adoção de um modelo neoliberal resultou na perda de sua prioridade, como ocorreu com as demais políticas sociais, notadamente na educação. Também resultou no aprofundamento da mercantilização do ensino, diante do avanço de um mercado internacional de universidades, e consequentemente na perda da hegemonia do ensino público superior, que por sua natureza tende a ser mais comprometido com a responsabilidade social. Ainda, na visão do autor, o movimento neoliberal impôs à universidade a demonstração de sua utilidade através da formação de mão de obra e produção de conhecimentos úteis ao mercado (SANTOS, 2005). Por outro lado, diante do enxugamento de recursos e da precarização da universidade, restou pouco espaço ao fortalecimento de práticas voltadas a atender aos anseios sociais, como a extensão universitária.

Nesse contexto, Boaventura de Sousa Santos identificou, no início da década de 1990, três crises enfrentadas pela Universidade Pública: i) “crise de hegemonia”, ii) “crise de legitimidade” e iii) “crise institucional”, decorrentes do conflito entre as novas funções a ela atribuídas, ligadas à formação de mão-de-obra, e as funções tradicionais, relacionadas à produção de pensamento crítico; das restrições de acesso e reivindicações de igualdade de oportunidades; bem como da pressão por respostas que demonstrassem eficácia do ponto de vista empresarial ou da responsabilidade social (SANTOS, 2005, pp. 137-138).

Coincidência ou não, é notório que a educação pública superior, sobretudo nos dias atuais, vem sofrendo diversos ataques, por meio de corte de verbas e discursos ultraconservadores que se tornaram relevantes na sociedade brasileira. Embora se reconheça que os ataques tenham ocorrido em um contexto maior de crise social, é imprescindível refletir em que medida tais agressões foram possibilitadas por uma crise de legitimidade experimentada pela universidade pública nas últimas décadas.

Das crises apontadas, Boaventura de Sousa Santos destaca ser "luta pela legitimidade" a mais necessária e difícil (SANTOS, 2005), salientando como urgentes no combate à crise: i) “o enfrentamento do novo com o novo” e ii) a reconquista da legitimidade por meio do que denomina “cinco áreas de ação”: “acesso; extensão; pesquisa-acção; ecologia de saberes; 
universidade e escola pública”. A pesquisa-ação, em sua visão, envolve trazer para o centro da pesquisa a satisfação das necessidades sociais, evitando que a sociedade seja mero objeto de pesquisa ou interesse do pesquisador, ao elevá-la à condição de sujeito que dialoga e apresenta à universidade as suas reais necessidades (SANTOS, 2005, pp. 176-177). A ecologia dos saberes seria uma forma de diálogo entre o conhecimento científico e o saber popular, tradicional, "provindo de culturas não ocidentais (indígenas, de origem africana, oriental etc.)” e apto ao enriquecimento da produção do conhecimento, que tradicionalmente tem negado tais saberes em prol da hegemonia de um conhecimento erudito. O eixo da extensão, por sua vez, deve ter papel central na reforma da universidade, como assinala Santos, notadamente na reconquista da legitimidade, possibilitando que a mesma tenha "uma participação activa na construção da coesão social, no aprofundamento da democracia, na luta contra a exclusão social e a degradação ambiental, na defesa da diversidade cultural” (SANTOS, 2005, p. 176).

Portanto, para Santos (2005, p. 177), a crise de legitimidade decorre, dentre outros fatores, do distanciamento da universidade pública com relação aos problemas sociais e da negação dos saberes populares como conhecimento válido. É possível afirmar que, em certa medida, tais fatores já eram objeto de preocupação por Paulo Freire quando este tecia as já mencionadas críticas à terminologia do termo extensão enquanto conhecimento transferido, unilateral, imposto pela universidade com relação à população.

A esse respeito, Rovati e D’Ottaviano (2017) consideram que a ação transformadora, numa perspectiva freireana, só acontece quando há a comunhão entre ensino, pesquisa e extensão em busca de processos que se consolidem no cotidiano "universidade-sociedadecidade” em forma de projeto coletivo "multi-inter-trans-disciplinar” que respeite as diferenças, valorize a diversidade, a democracia e promova a justiça social, uma vez que a cidade, objeto principal do planejamento urbano, é complexa e heterogênea. Dessa forma, tem havido uma crescente defesa pela ampliação de discursos e práticas da extensão universitária como instrumento de diálogo com a sociedade e transformação socioeducativa (ROVATI \& D’OTTAVIANO, 2017; D’OTTAVIANO \& ROVATI, 2019). Um elemento central nesse tipo de extensão universitária é a “prática dialógica formativa territorializada” (D’OTTAVIANO, 2019; BASSANI \& D’OTTAVIANO, 2019), no âmbito do exercício da cidadania e do direito à cidade. Esta perspectiva formativa, dialógica e territorializada da extensão universitária visa proporcionar aos educandos e educadores o conhecimento profundo da realidade social em que atuarão, além do estabelecimento de trocas de conhecimento, metodologias e estratégias de ação coletiva com os grupos territorializados. 
Diante do contexto apresentado, verifica-se a relevância da extensão universitária por meio da contribuição com a construção de diálogos interdisciplinares voltados à solução de problemas territorializados relacionados, especialmente na área do Planejamento Urbano, à ausência de direitos de dimensão territorial, como moradia, mobilidade, infraestrutura urbana, isto é, da função social da cidade, em prol da efetivação do direito à cidade. Muitas das ações desenvolvidas junto aos grupos sociais envolvidos ocorrem a partir de propostas práticas que buscam ultrapassar o âmbito da extensão universitária voltada apenas à prestação de serviços, como já apontado por Rovati e D’Ottaviano (2017) e D’Ottaviano e Rovati (2019) ${ }^{52}$.

Em vista dessas considerações, importa para este trabalho a abordagem de Bassani \& D’Ottaviano (2019) sobre a extensão como complementar e subsidiária do ensino e da pesquisa, que pode ser desenvolvida também em forma de "projeto continuado”, de acordo com as dinâmicas do território. É preciso “Aprender com o território”, ou, ainda, notar que alunos, professores e população devem “aprender a se territorializar”, a adentrar os códigos do território (BASSANI \& D’OTTAVIANO, 2019).

Quanto ao atual desmanche do Estado e da desvalorização do ensino e universidade públicos, Camilla D’Ottaviano (2019) assinala que a extensão universitária se vê confrontada por duas situações defendidas pelo atual governo, as quais são contraditórias com a sua essência: o ensino a distância (EaD) e o programa Future-se. Tal quadro impõe ao pesquisador a reflexão a respeito da sua responsabilidade social, bem como da necessidade de diversificar os métodos e linguagens utilizadas na produção do conhecimento.

É neste contexto que o território desempenha papel primordial. A importância de se territorializar as políticas e as ações tem sido cada vez maior, por conta do cenário apresentado, tanto para a constituição da práxis, como para processos pedagógicos, entendendo-se que o contato com a realidade e a prática seguida de reflexão constituem processos de conscientização. Tal processo é urgente não só por sua importância como meio de enfrentamento de uma possível crise de legitimidade experimentada pela universidade pública,

\footnotetext{
52 Cabe ressaltar, contudo, que as definições e as atividades denominadas de extensão compõem um leque muito vasto e heterogêneo, ocasionando a principal questão que muitos docentes e pesquisadores vem combatendo: a extensão como “tudo aquilo que não é ensino e pesquisa” (D’OTTAVIANO, 2019). Tal concepção deve ser combatida no intuito de consolidar a extensão como uma categoria autônoma relacionada à formação cidadã. Rovati e D’Ottaviano (2017) apontam a esse respeito dois grandes desafios para a extensão universitária: fortalecer o debate e a prática extensionista, bem como consolidá-la no âmbito da pós-graduação, pois, desta forma, poderia se criar um campo fértil de prática e reflexão da prática, na busca por ampliar e ressaltar o caráter político da extensão universitária, bem como a dimensão pública da universidade (ROVATI \& D’OTTAVIANO, 2017).
} 
mas sobretudo diante do seu potencial educador. Veremos adiante o desenvolvimento das discussões envolvendo o tema cidade como território educador.

Figura 23 - Linha do tempo com ilustração de fatos relevantes na escala global, de acordo com o tema tratado nesta pesquisa
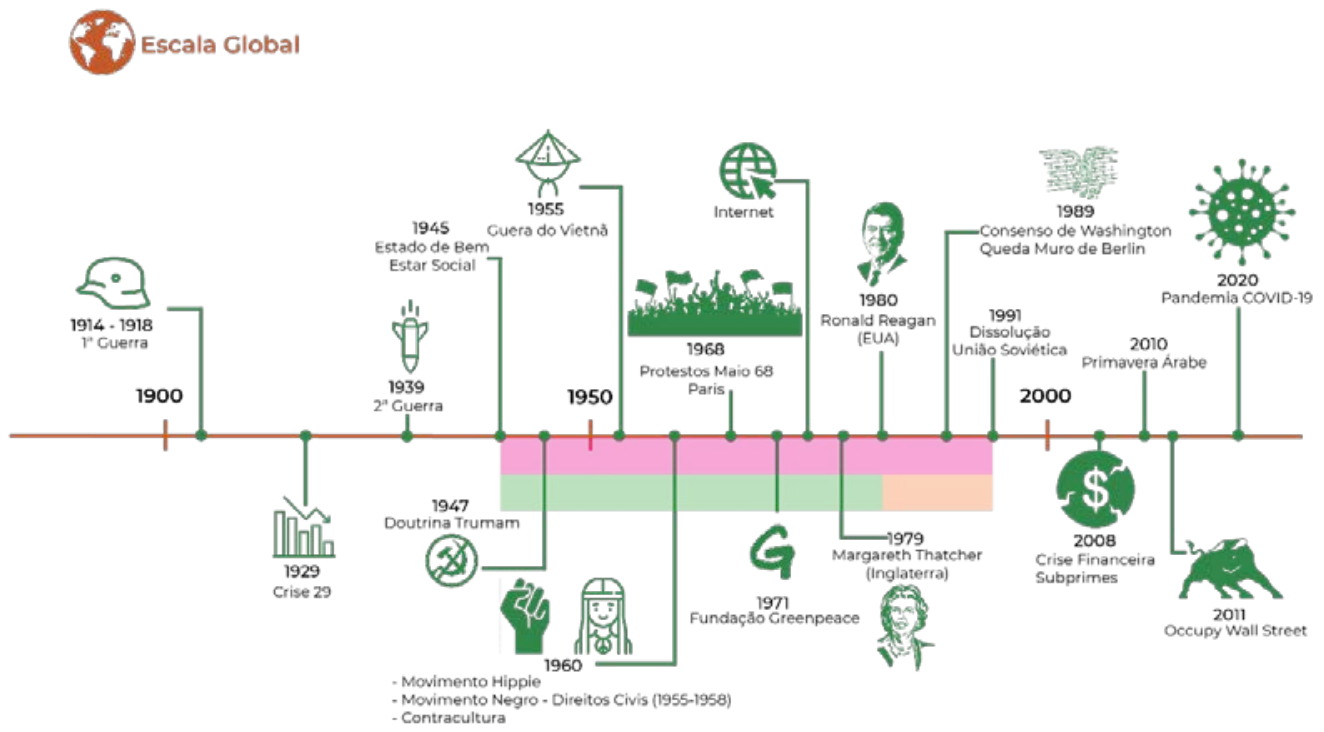

Weriodo Cuerra Fía

In Fstaco de Bem Fstar Social

Ascensso Neciberalismo

Fonte: idealização da autora, elaboração Camilla Ortega.

Figura 24 - Linha do tempo com ilustração de fatos relevantes para as ciências naturais e humanas, de acordo com o tema tratado nesta pesquisa

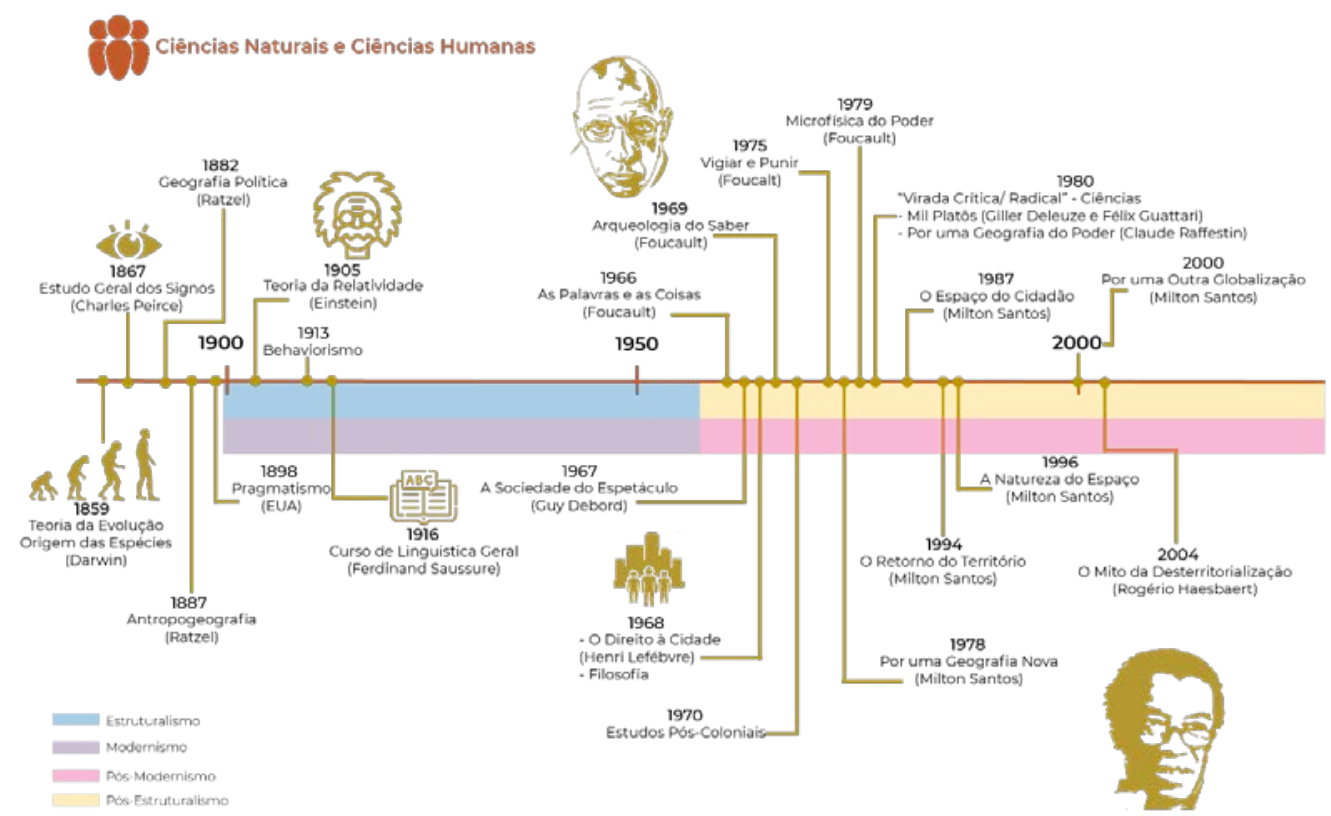

Fonte: idealização da autora, elaboração Camilla Ortega. 
Figura 25 - Linha do tempo com ilustração de fatos relevantes para a educação, de acordo com o tema tratado nesta pesquisa

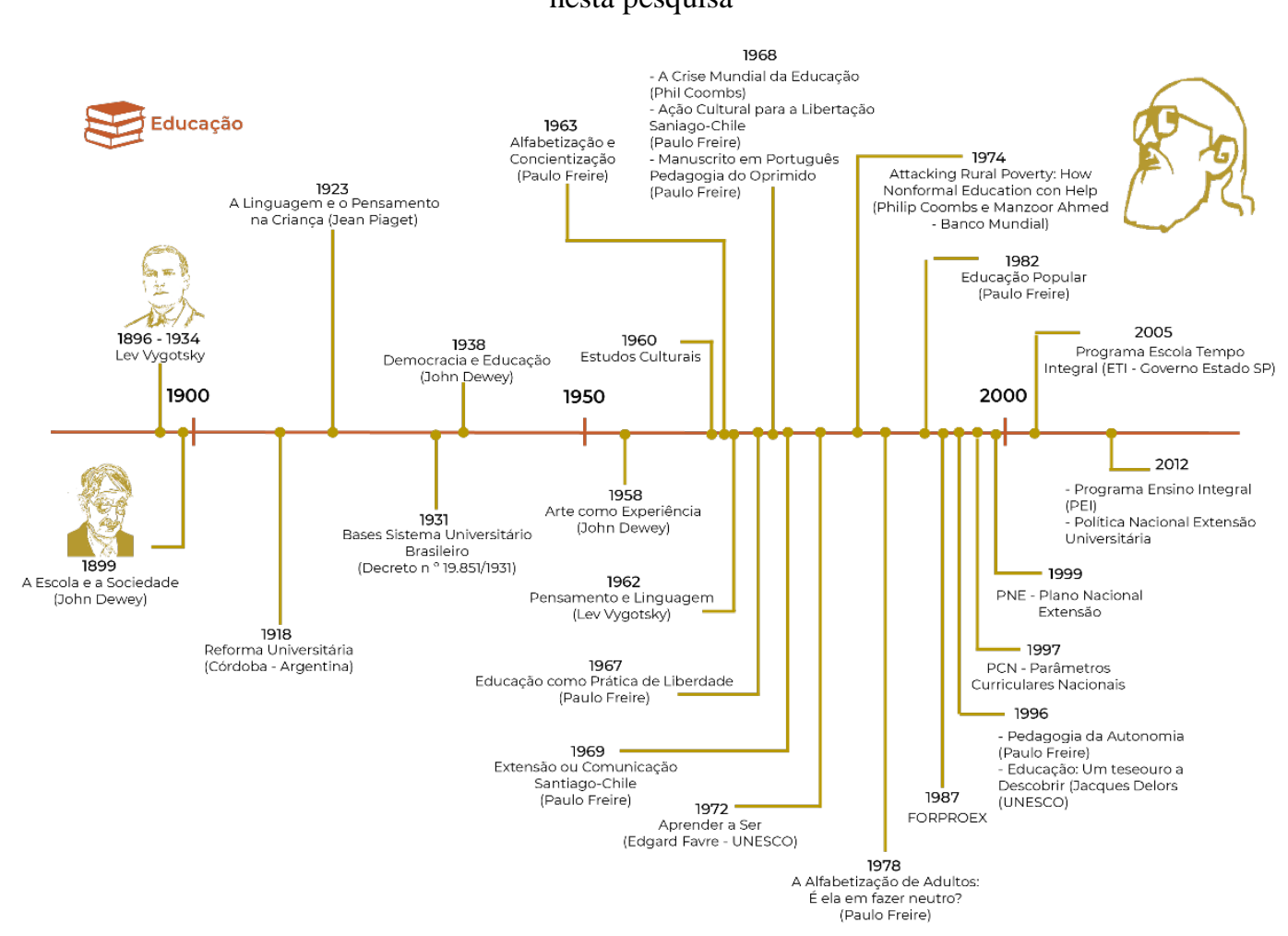

Fonte: idealização da autora, elaboração Camilla Ortega.

Figura 26 - Linha do tempo com ilustração de fatos relevantes na escala local, de acordo com o tema tratado nesta pesquisa

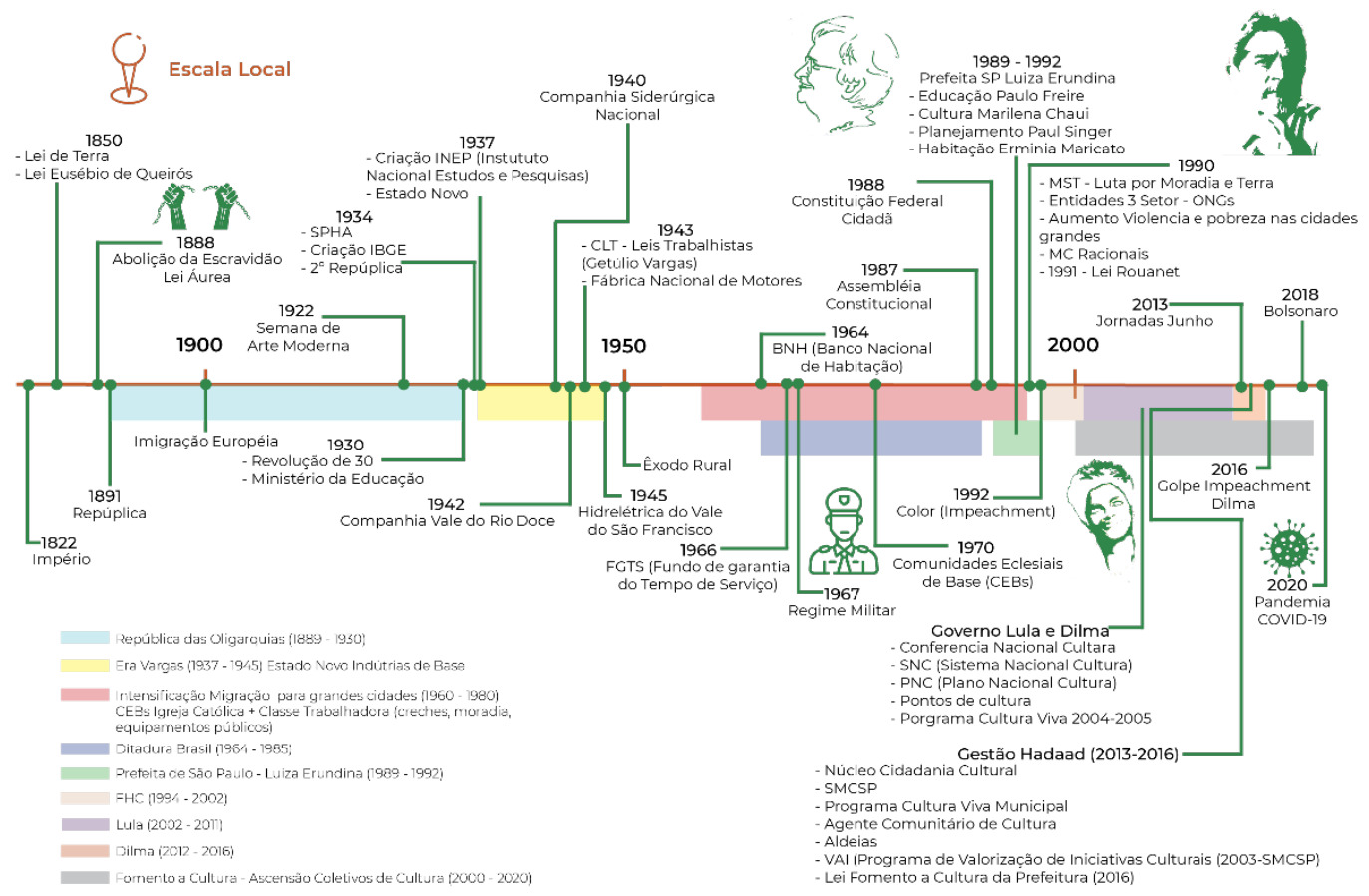

Fonte: idealização da autora, elaboração Camilla Ortega. 


\subsection{Caminhando para o século XXI: a cidade como território educativo}

No ano de 1990, ocorreu o Primeiro Congresso Internacional de Cidades Educadoras, em Barcelona (Espanha), no bojo de acontecimentos como a assinatura do tratado da Convenção sobre os Direitos da Criança (1989), da Declaração Mundial sobre Educação para Todos (1990) e Cúpula Mundial pela Criança (1990). No âmbito ambientalista ocorreu, dois anos depois do Primeiro Congresso Internacional de Cidades Educadoras, a Cúpula da Terra no Rio de Janeiro (1992), cujo resultado produziu a Carta da Terra ${ }^{53}$ ao final da década de 1990, com objetivo de construir uma sociedade global no século XXI, pautada no desenvolvimento sustentável e justiça social. Na esfera dos estudos urbanos a discussão em torno da globalização e das cidades globais intensificava-se, enquanto no Brasil acabava de ser aprovada a Constituição Cidadã, em 1988, com contribuições importantes para a sociedade e para a cidade, pautadas em princípios democráticos.

Como abordado na seção anterior, o relatório de Edgar Faure (1972) foi fundamental para a constituição de novos discursos e práticas alternativas à educação formal e, de acordo com Collet-Sabé \& Subirats (2016), também influenciou o desenvolvimento do Movimento das Cidades Educadoras, pois além de cunhar o termo "cidade educativa”, seu conteúdo apontava para um conceito de educação ao longo da vida, que formaria um homem integral e completo, coerente com as novas e rápidas transformações sociais. Ademais, a ideia do "duplo desdobramento” da educação subjazia a ideia de que todo o território poderia ser educador, bem como da relação entre educação e território atrelada a um projeto educativo "ao longo da vida" (COLLET-SABÉ \& SUBIRATS, 2016). A ideia de uma cidade educadora propunha uma gestão local ativa e participativa, em que se deveria “educar na cidade, a cidade e pela cidade”. Portanto, uma cidade educadora deveria possuir a consciência dos potenciais educativos de seus territórios para que, através da articulação de governos locais e agentes do território, pudessem ocorrer transformações em direção à cidadania (COLLET-SABÉ \& SUBIRATS, 2016).

Do Primeiro Congresso Internacional de Cidades Educadoras ${ }^{54}$ produziu-se como resultado a Carta das cidades educadoras ${ }^{55}$ que formulou princípios básicos para orientar o “perfil educativo” de uma cidade. Desse modo, uma cidade com o perfil de "educadora” deve exercer, além da “função tradicional” - “econômica, social, política e de prestação de serviços”

\footnotetext{
${ }^{53}$ Disponível em: http://www.ebooksbrasil.org/adobeebook/cartadaterra.pdf. Acesso em: 20 set. 2019.

${ }^{54} \mathrm{O}$ Movimento das Cidades Educadoras angariou mais de 400 cidades ao redor do mundo.

${ }^{55}$ Revisada em 1994 no III Congresso Internacional que ocorreu em Bolonha, Itália, e em 2004 em Gênova.
} 
-, a "função educadora”, traduzida por meio da “intencionalidade e responsabilidade" de formar a população (AICE, 1994). Os princípios contidos na Carta de $2004^{56}$ possuem 3 eixos norteadores: i) “o direito à cidade educadora”, entendido como uma "extensão do direito à educação”; ii) “o compromisso da cidade”, entendido como o compromisso de zelar por uma “identidade” ou uma "imagem atrativa” perante seu território e outras cidades no âmbito internacional; iii) “ao serviço integral das pessoas”, entendido como a capacidade de diagnosticar o impacto das propostas e de oferecer à população uma formação que garanta um “posto na sociedade”, isto é, uma colocação no mercado de trabalho. No geral, os princípios contidos na carta são pautados por questões concernentes à administração municipal, mais estreitamente vinculado ao eixo i) por meio da articulação e promoção de incentivos a projetos educativos; ao planejamento urbano, mais estreitamente relacionado ao eixo ii), incumbido de promover um espaço público acessível e uma “imagem atrativa” da cidade; e ao acesso à informação, que por meio das Tecnologias de Informação e Comunicação (TIC) devem estabelecer instrumentos e linguagens para a formação da população.

De acordo com Collet-Sabé \& Subirats (2016), foram criados no final da década de 1990 em algumas cidades da Catalunha os Projetos Educativos de Cidade (PEC), baseados na filosofia das Cidades Educadoras, os quais consistiram em “ferramentas metodológicas” para construir uma cidade educadora. Para os autores, as três concepções de território utilizadas nessa proposta respondem às três dimensões da Cidade educadora:

i) “Educar na cidade” - consiste em compreender o "território como entorno”, como o meio onde ocorrem as práticas educativas.

ii) “Educar a cidade” - relaciona-se à dimensão de território enquanto “conteúdo”, dadas as suas dimensões geográficas, históricas, sociais, culturais, econômicas etc.

iii) “Educar a partir da cidade” - considera o território como um “agente educativo de primeira ordem”, por meio da ação conjunta de sujeitos ativos, como governo local e organizações da sociedade civil, na construção de um “território educador”.

\footnotetext{
56 A carta, atualizada em 2004, apresenta algumas declarações sob as quais foi inspirada como: Declaração Universal dos Direitos do Homem (1948), o Pacto Internacional dos Direitos Econômicos, Sociais e Culturais (1966), a Declaração Mundial da Educação para Todos (1990), a Declaração Mundial sobre a Sobrevivência, a Proteção e o Desenvolvimento da Criança (1990) e a Declaração Universal sobre Diversidade Cultural (2001). Desde sua primeira publicação em 1990, a carta dá ênfase ao protagonismo das crianças e dos jovens nos processos educativos e como cidadãos ativos. Cf. http://www.edcities.org/rede-portuguesa/wpcontent/uploads/sites/12/2018/09/Carta-das-cidades-educadoras.pdf. Acesso em: 15 out. 2019.
} 
De acordo com Collet-Sabé \& Subirats (2016), os PECs tiveram três fases, a primeira caracterizada pelo plano estratégico (1998-2004), a segunda pelo plano participativo (20052009) e a terceira pelo trabalho educativo em rede, pelo aspecto do empoderamento dos indivíduos e da sustentabilidade (a partir de 2009). As principais estratégias de ação centravamse na articulação do governo local com os agentes do território, a adoção da educação como eixo transversal a todas as políticas públicas municipais e diagnósticos em escala de bairro com ações participativas da comunidade. A terceira fase dos PECs são incorporados aos Planos Educativos de Entorno (PEE), cuja principal característica consiste na integração escolafamília-comunidade, em que a escola se constitui como uma centralidade, por meio da articulação de agentes e práticas no território (COLLET \& SUBIRATS, 2016).

Vale destacar que, por mais que os PECs tenham tido dimensões participativas, a raiz de sua constituição no início da década de 1990 revela o contexto do que convencionou-se chamar de "cidades globais". Parece sintomático de que ser uma "cidade educadora" significa ter uma "etiqueta de qualidade" perante o cenário internacional. A ênfase dada ao Planejamento Urbano na promoção de espaço públicos de qualidade, acessíveis e de uma “imagem atrativa”\$77 da cidade também remete ao Planejamento Estratégico catalão, marco dos Jogos Olímpicos de 1992 que ocorreram em Barcelona. Tal “modelo” foi propagado pelos catalães para outras cidades do mundo, como o Rio de Janeiro, que no início da década de 1990, por meio da consultoria catalã, elaborou seu planejamento estratégico e em 2016 sediou os Jogos Olímpicos com a construção de megaobras sob a lógica do planejamento estratégico. Em crítica a esse modelo, Carlos Vainer assinala que é evidente o incentivo à “cidade competitiva global” como palco e objeto dos grandes negócios, em alinhamento com a globalização da economia e da comunicação e pela exacerbação do neoliberalismo, cuja influência na política urbana ocorreu por meio de uma lógica empresarial (VAINER, 2011; 2017). A crítica central nesse novo modus operandi consiste na promoção do consenso em direção à eficiência e competitividade, em detrimento das discussões relacionadas aos conflitos sociais, portanto, do aniquilamento da política e do exercício da cidadania (VAINER, 2017).

Da mesma forma, tal caráter contextualista e consensualista também foi verificado nos PECs, como observaram Collet \& Subirats (2016), acerca dos temas que não foram abordados

\footnotetext{
${ }^{57}$ A respeito do princípio 15 da Carta de 2004 e os aspectos alinhados ao contexto do planejamento estratégico: “15. Uma cidade educadora deverá saber encontrar, preservar e divulgar a sua própria identidade. Deste modo estará a fazer algo único que servirá de base a um diálogo fértil com os seus habitantes e com outras cidades. A valorização dos seus costumes e das suas origens deve ser compatível com os modos de vida internacionais. Poderá assim oferecer uma imagem atractiva sem desvirtuar o seu ambiente natural e social” (AICE, 1990 apud AICE, 1994, p. 3 - grifo nosso).
} 
em nenhum dos projetos, como as questões relacionadas à desigualdade social e a relação com a educação, as relações entre o urbanismo e a formação para a cidadania, dentre outros. A partir disso, os autores afirmam que, no âmbito da Catalunha e da Espanha, a filosofia da Cidade Educadora mostrou-se um tanto abstrata e distante das políticas públicas e territoriais, já que não houve grandes mudanças; contudo, a concepção de território como "agente educativo de primeira ordem” foi amplamente disseminada (COLLET-SABÉ \& SUBIRATS, 2016).

Já no Brasil e nos Estados Unidos, na década de 1980, ocorreram no âmbito da educação popular algumas experiências similares aos PECs/PEEs da terceira geração, no que tange ao envolvimento da comunidade educativa e a relação com o território, como a citizenship school, de Myles Horton, e a formação para e pela cidadania, de Paulo Freire (COLLET \& SUBIRATS, 2016). Dadas as devidas diferenças em relação aos contextos socioculturais e territoriais, o ideário da Escola Cidadã e da Cidade Educadora, em busca de uma relação entre escola e o território, também estão presentes na América Latina (COLLET-SABÉ \& SUBIRATS, 2016; GADOTTI, 2003).

Gadotti (2003) assinala que a década 1990 foi de “inovação e experimentação”, o que possibilitou constituir um movimento em oposição à educação neoliberal mercadológica pautada na "internacionalização da agenda da educação". Na sequência, a primeira década do século XXI trouxe grandes eventos para se pensar sociedade, como o Fórum Mundial de Educação (2001) e o Primeiro Encontro Nacional das Escolas Cidadãs (2001), o Fórum Social Mundial (2002) e o Primeiro Encontro Internacional de Escolas Cidadãs (2002) (GADOTTI, 2003). Em consonância com a “movimentação” da década de 1990, segundo o autor, o Movimento da Escola Cidadã influenciaria as primeiras décadas do século XXI, tal qual foi o Movimento da Escola Nova, constituído no final do século XIX e que influenciou a educação do século XX (GADOTTI, 2003).

A Escola Cidadã origina-se como movimento no final da década de 1980 e início de 1990, a partir da experiência de Paulo Freire na Secretaria Municipal de Educação de São Paulo, experiência tida como um dos expoentes da transformação da educação popular em política pública (GADOTTI, 2003). Ademais, os fundamentos e princípios da “escola cidadã” partilham dos preceitos da educação popular latino-americana e da pedagogia freireana, pois objetivam uma "educação conscientizadora” e democrática, que proporcione a autonomia e a libertação dos sujeitos. De acordo com o autor, a escola cidadã possui demandas relativas à “democratização da gestão”, à implementação de “métodos participativos” e à “transformação curricular” e das relações sociais (GADOTTI, 2003). Deste modo, considera que a escola cidadã 
necessita de uma cidade educadora, em vista que o diálogo entre ambas é inevitável e imprescindível. Uma escola participativa, com mecanismos de participação popular passa a ser “um novo território de construção da cidadania” (GADOTTI, 2003).

Para além dos movimentos da sociedade civil organizada e dos profissionais da educação, houve também um certo reflexo dessa concepção da cidade como território educativo, no âmbito dos governos locais. Diante dessas considerações, apresento de maneira sintética a São Paulo Carinhosa ${ }^{58}$, implementada na Gestão Municipal da Prefeitura de São Paulo (2013-2016), cujos objetivos centravam-se na promoção do desenvolvimento integral das crianças com idade entre 0 (zero) e 6 (seis) anos, de forma a integrar ações com as secretarias municipais, como a da cultura e do desenvolvimento urbano, a partir do olhar da criança e da família. Ressalto neste trabalho as políticas no âmbito da cultura e do desenvolvimento urbano por terem privilegiado a dimensão territorial em suas relações com a cultura e a educação.

Ainda a respeito das relações cultura, território e educação, destaco que a Política Municipal de Cultura teve papel importante no desenvolvimento do Circuito Municipal de Cultura (CMC) que buscou integrar todas as regiões do município através da descentralização das atividades culturais nos espaços públicos e equipamentos, tanto do centro como da periferia, a partir do tripé: i) programação; ii) formação; iii) território. Tal abordagem, ao colocar a criança como uma questão central do projeto de cidade desejada, operou pela interdisciplinaridade e intersetorialidade, e ambicionou "transformar São Paulo em uma cidade educadora” (BONDUKI; FERRON \& ALVES, 2016, p. 391). Outra política que buscou integrar o território e a educação, por meio da Política de Desenvolvimento Urbano, consistiu no Programa Território CEU, em consonância com as alterações realizadas no Plano Diretor Estratégico de São Paulo naquela gestão, como ativação e ocupação de espaços públicos. Uma das estratégias se deu através da Rede De Estruturação Urbana Local, pautadas no desenvolvimento local de áreas de vulnerabilidade social e ambiental, o que promoveria a criação de uma centralidade local e a constituição de uma referência espacial.

\footnotetext{
${ }^{58}$ Decreto Municipal 54.278, de 28 de agosto de 2013, institui a Política Municipal para Desenvolvimento Integral da Primeira Infância na cidade de São Paulo - São Paulo Carinhosa. O Decreto foi revogado e substituído pelo Decreto 58.294, de 28 de junho de 2018, da gestão posterior, que regulamenta o artigo $8^{\circ}$ da Lei $\mathrm{n}^{\circ} 16.710$, de 11 de outubro de 2017, e dispõe sobre a instituição de Comitê Gestor Intersetorial da Política Municipal Integrada pela Primeira Infância. O novo decreto contém basicamente o mesmo conteúdo, mas com alterações sensíveis, em vista de que antes existiam 14 secretarias, a contar: a Secretaria Municipal de Educação, de Saúde, de Assistência e Desenvolvimento Social e a de Direitos Humanos e Cidadania, as quais permaneceram no último Decreto. A partir daqui todas as secretarias foram substituídas pela Secretaria Municipal de Inovação e Tecnologia, como a de Cultura, a de Esporte, Lazer e Recreação, a de Segurança Urbana, a de Políticas para as Mulheres, a de Promoção da Igualdade Racial, a de Pessoa com Deficiência e Mobilidade Reduzida, a do Verde e Meio Ambiente, a de Serviços e a de Coordenação das Subprefeituras.
} 
Por fim, é importante lembrar que, a despeito da constituição de discursos, projetos, “experimentações” em reação ao cenário da “cidade neoliberal”, eles não escapam às suas contradições internas e externas, como parte do sistema capitalista globalizado em que estão inseridos. Importante também ressaltar que a “importação” de modelos prontos da Europa ou de qualquer outro lugar ocasionaria um descolamento entre a realidade social, a prática e o discurso. Desse modo, compreender as manifestações que ocorreram no campo de disputa da educação requer compreender sua historicidade, seus agentes e seus territórios. Compreendo, assim, que o território “educador”, ou “educativo”, existe por meio da práxis dos sujeitos, em que os componentes espaciais, relacionais e multidimensionais estejam inseridos em um processo de conscientização, por meio do diálogo entre os sujeitos.

Apresentadas as bases teóricas que se relacionam às discussões envolvendo educação e território, será feita no próximo capítulo uma análise das práticas verificadas nos territórios de Bororé e Perus, no município de São Paulo. A análise objetiva compreender a relação entre território, educação e cidadania, por meio da concepção de educação freireana. 


\section{TERRITÓRIO E EDUCAÇÃO: A PRÁXIS EDUCATIVA NOS TERRITÓRIOS PERIFÉRICOS DE SÃO PAULO}

\subsection{Bororé}

O Bororé é um bairro do município de São Paulo/SP, situado no distrito do Grajaú, que, em conjunto com os distritos de Cidade Dutra e Socorro, é administrado pela subprefeitura de Capela do Socorro, localizada na macrorregião Sul 2 de São Paulo ${ }^{59}$. Os distritos mais próximos do vetor de urbanização sudoeste, como Socorro, possuem uma área urbanizada mais consolidada do que as áreas mais ao sul, como o Grajaú. Uma característica peculiar dessa região é a presença de remanescentes da Mata Atlântica e das bacias hidrográficas Guarapiranga, Billings e Capivari-Monos (PREFEITURA DO MUNICÍPIO DE SÃO PAULO, 2016).

Mapa 7 - Localização dos distritos em que o estudo ocorreu: Perus e Grajaú

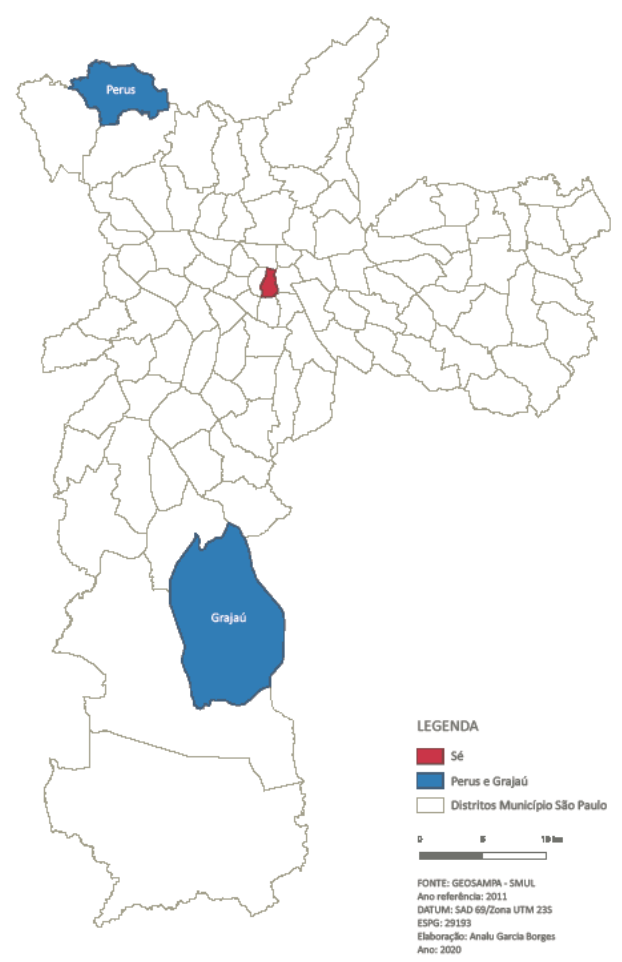

Fonte: Secretaria Municipal de Licenciamento - SMUL/SP. Elaboração: autora.

\footnotetext{
${ }^{59}$ A macrorregião Sul 2 é composta pelas subprefeituras de Santos Amaro, Campo Limpo, Cidade Ademar, Capela do Socorro, M’Boi Mirim e Parelheiros.
} 
Mapa 8 - Localização da Subprefeitura de Perus, Sé e Capela do Socorro

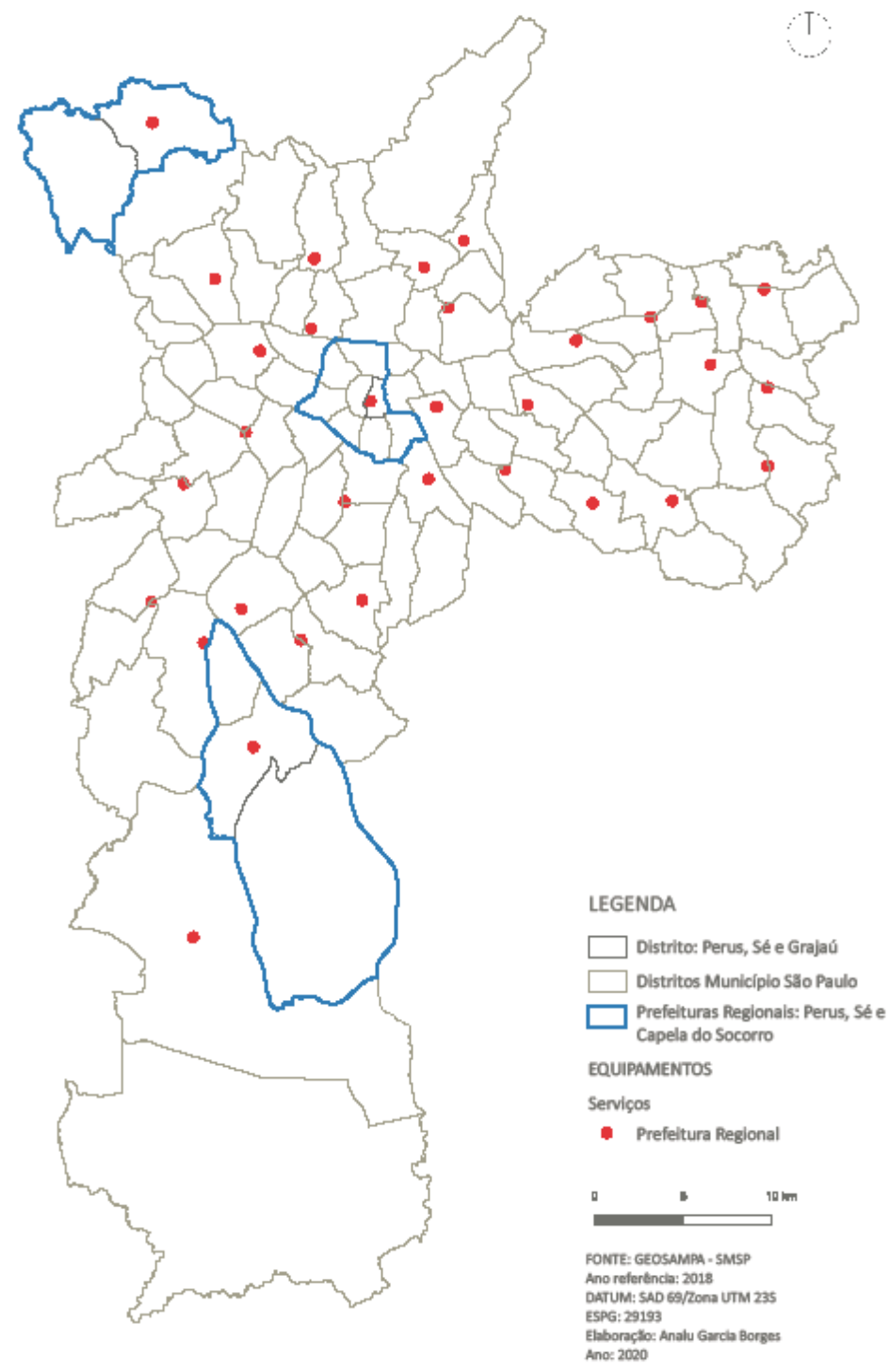

Fonte: Secretaria Municipal de Subprefeituras - SMSP/SP. Elaboração: autora. 
Mapa 9 - Índice Paulista de Vulnerabilidade Social

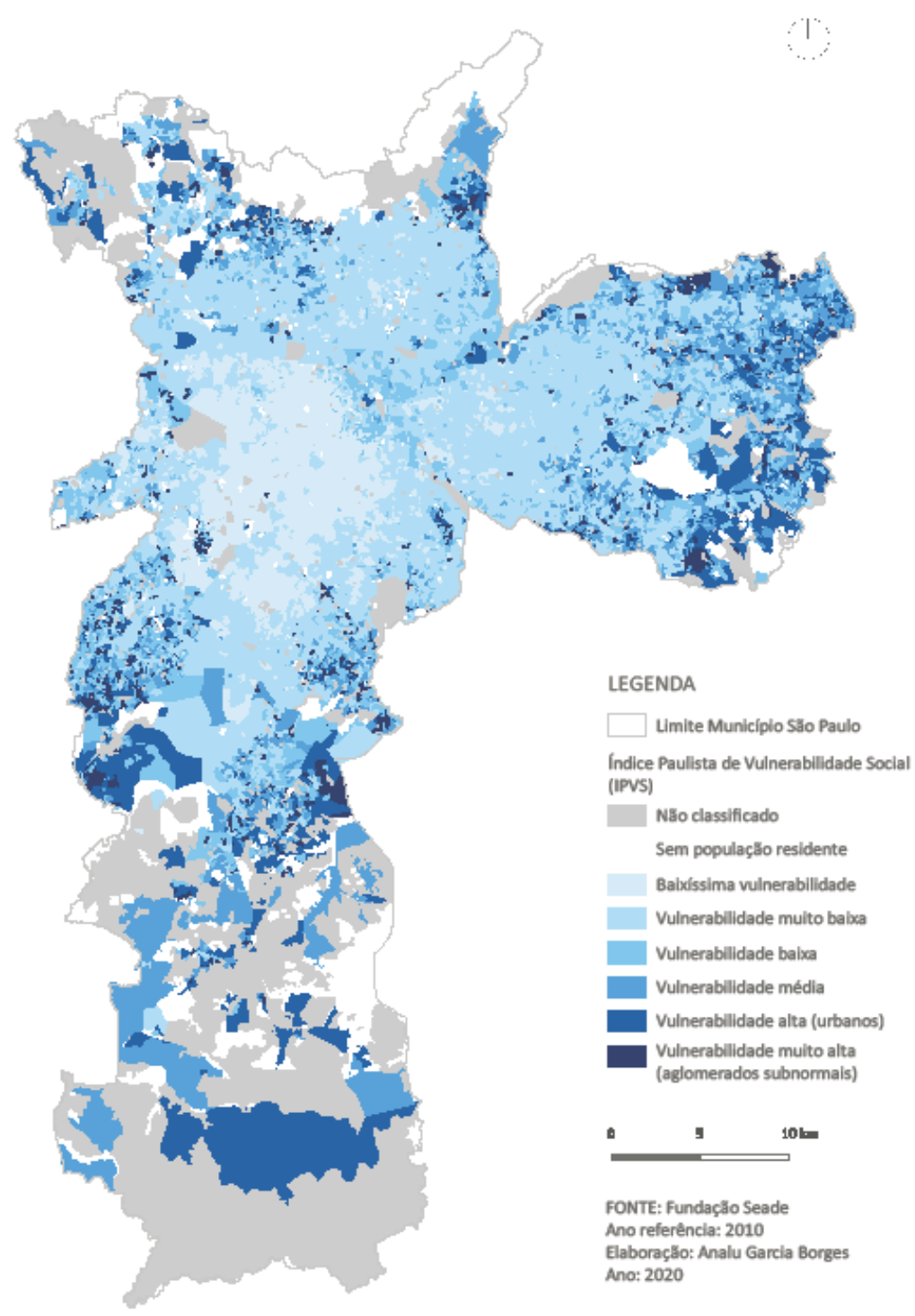

Fonte: Fundação Seade (2010). Elaboração: autora. 


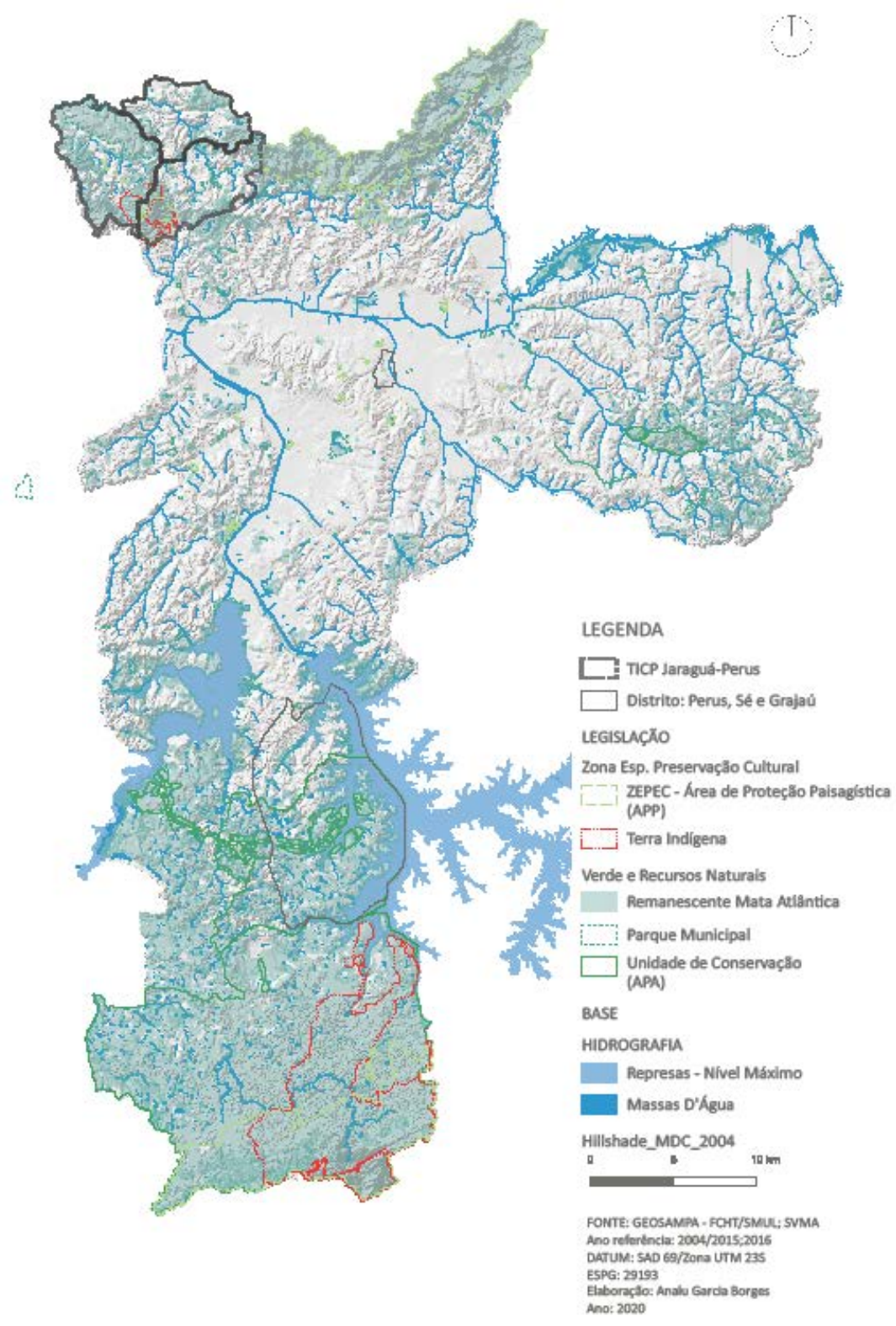

Fonte: FCHT/Secretaria Municipal de Licenciamento - SMUL/SP, Secretaria do Verde e Meio Ambiente SVMA/SP - Ano de referência: 2004/2015, 2016. Elaboração: autora.

Enquanto a região norte da subprefeitura apresenta padrões de urbanização mais consolidados e intensa atividade comercial e industrial, configurando Zonas de Centralidade e Desenvolvimento Econômico por meio da criação de empregos, mais ao sul há a presença de remanescentes da Mata Atlântica, chácaras, sítios, sendo esta porção parte da área rural 
enquadrada nas Macroáreas de Contenção Urbana e Uso sustentável e de Preservação de Ecossistemas Naturais. A região é contemplada com os parques urbanos Shangrilá, Cantinho do Céu e o Parque da Orla do Guarapiranga, bem como os parques naturais municipais de proteção integral do Rodoanel, do Bororé e de Varginha. As configurações desse território rural, com produção hortifrutigranjeira para o desenvolvimento local, bem como dos remanescentes da Mata Atlântica possibilitaram o desenvolvimento do Polo de Ecoturismo de Parelheiros, subprefeitura vizinha ao sul (PREFEITURA DO MUNICÍPIO DE SÃO PAULO, 2016).

Figura 27 - Distrito do Grajaú e a mancha urbana mais ao norte e a área rural ao sul

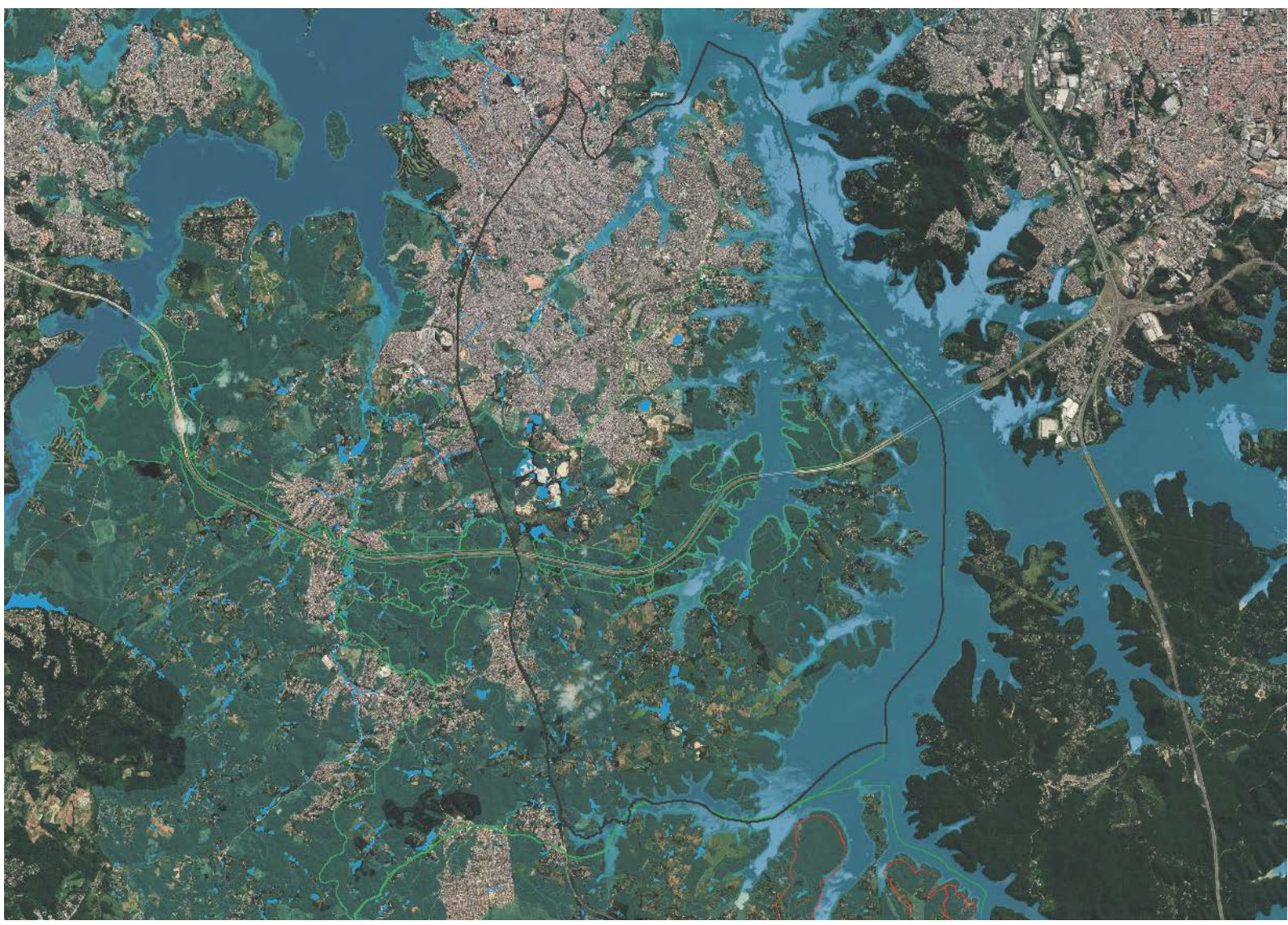

Fonte: Secretaria Municipal de Licenciamento - SMUL/SP, Secretaria do Verde e Meio Ambiente SVMA/SP e Google Earth - Ano de referência: 2015, 2016. Elaboração: autora.

Santo Amaro, antigo município que foi incorporado à cidade de São Paulo em 1935, tem uma incidência histórica no desenvolvimento da região onde hoje se localizam os distritos administrados pela subprefeitura de Capela do Socorro. As determinações territoriais dessa região tiveram influências marcantes da produção agrícola, extrativista e industrial (SANTOS, 2003). 
Figura 28 - Folder produzido pelos “Agentes Marginais”/Imargem, 2010. Material compartilhado com a Casa Ecoativa e utilizado em suas atividades pedagógicas

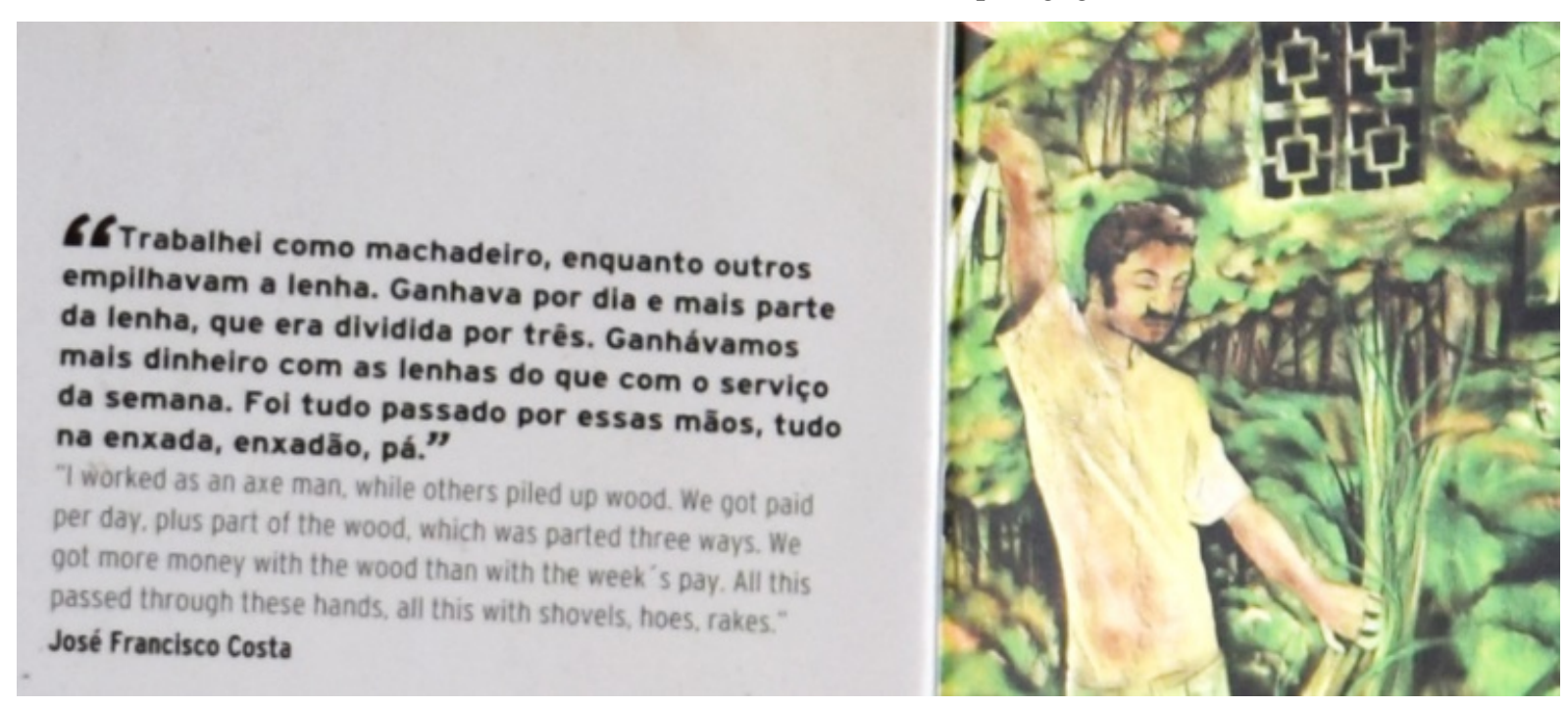

Fonte: Agentes Marginais/Imargem, 2010, foto de acervo pessoal.

Segundo Zenha (1977 apud SANTOS, 2003) a região também era caminho entre o planalto e o litoral paulista, por onde os indígenas percorriam as trilhas entre os aldeamentos de Ibirapuera e Itanhaém, com os respectivos nomes católicos de Santo Amaro de Ibirapuera e Conceição de Itanhaém. Contudo, a consolidação da ocupação dessa região ocorreu, notadamente, por meio dos fluxos migratórios no século XIX, que culminaram na formação da Colônia Alemã em 1829 na região de Parelheiros, bem como da migração japonesa em meados do século XX (SANTOS, 2003). Ademais, a construção da barragem do Rio Guarapiranga em 1907, da represa Billings em 1925 e da estrada Washington Luís e 1928 reorganizaram o arranjo espacial ligando os “nós” e criando “redes” de circulação, conformando a nova “tessitura” e o padrão de ocupação da região, que abastecia a cidade com a produção agrícola e madeireira.

O represamento do rio Guarapiranga em 1907 coincide com o projeto de modernização da capital paulista por meio do controle do meio pela técnica, isto é, da "vazão do rio Tietê e, consequentemente, a produção de energia”, materializando-se assim a cidade como o símbolo do "progresso" (SANTOS, 2003, p. 62). Desse modo, o empreendimento da empresa estrangeira do Canadá - “The São Paulo Trainway, Light and Power Company Ltda” possibilitou a formação de áreas de lazer, chácaras e clubes na região, como o Yacht Club Santo Amaro. Outro empreendimento da empresa Light nesse contexto culminou no represamento dos rios Jurubatuba e Bororé entre 1925 e 1927 com a finalidade de suprir às demandas de energia da crescente urbanização paulistana; a represa Billings carrega o nome do engenheiro norte-americano que a projetou - Asa White Kenney Billings (SANTOS, 2003). Portanto, tal 
reestruturação no arranjo espacial conformou vetores de urbanização e a expansão industrial para a região sul, notadamente a partir da década de 1960 .

Figura 29 - Folder produzido pelos “Agentes Marginais”/Imargem, 2010. Material compartilhado com a Casa Ecoativa e utilizado em suas atividades pedagógicas
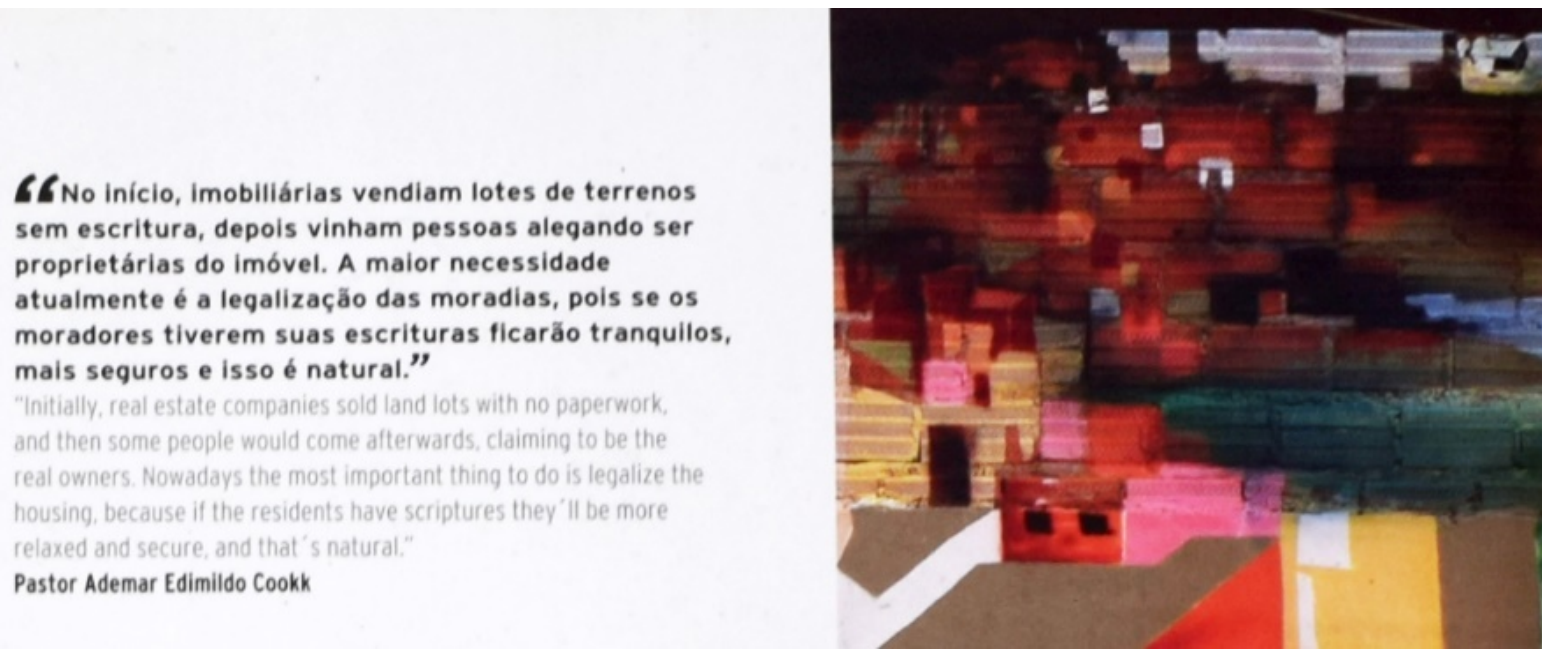

Fonte: Agentes Marginais/Imargem, 2010, foto de acervo pessoal.

Com a expansão das fábricas para a região sul, decorrente da crescente industrialização de São Paulo, houve também mudanças nos fluxos internos com a migração nacional para atender às demandas de mão-de-obra barata e a consequente ocupação popular da região, conformando o que se convencionou chamar de territórios periféricos. Tal ocupação se deu notadamente próxima aos mananciais, gerando um agravamento da questão urbana em torno da moradia e da preservação do meio ambiente. 
Figura 30 - Folder produzido pelos “Agentes Marginais”/Imargem, 2010. Material compartilhado com a Casa Ecoativa e utilizado em suas atividades pedagógicas.
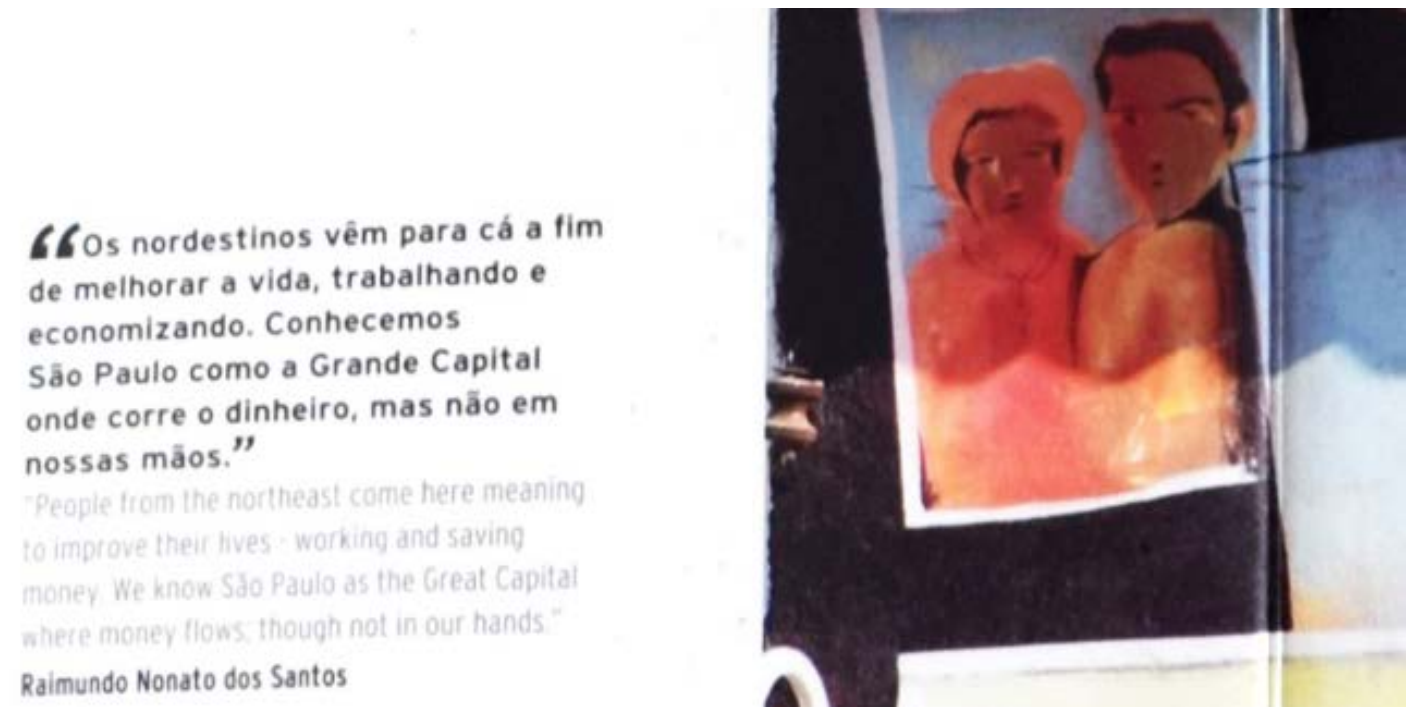

Fonte: Agentes Marginais/Imargem, 2010, foto de acervo pessoal.

Como decorrência da ocupação, surge a preocupação com relação à qualidade das águas da região, hoje responsáveis por abastecer 30\% da metrópole paulistana (PREFEITURA DO MUNICÍPIO DE SÃO PAULO, 2020) ${ }^{60}$. Neste contexto, o Estado de São Paulo editou em 1975 a Lei Estadual $n^{\circ}$ 898, disciplinando “o uso do solo para a proteção dos mananciais e recursos hídricos no interesse da Região Metropolitana da Grande São Paulo”. Também diante do crescimento da ocupação irregular, notadamente nos distritos de Cidade Dutra e Grajaú, o município de São Paulo instituiu Zonas Especiais de Interesse Social (ZEIS) 1 e $4^{61}$, instrumentos de planejamento urbano voltados a fomentar melhorias urbanas, regularização fundiária e preservação ambiental em áreas estratégicas da cidade, notadamente em regiões ocupadas por populações vulneráveis ${ }^{62}$. 
Mapa 11 - Lei de Parcelamento, Uso e Ocupação do Solo da Subprefeitura de Capela do Socorro (Lei ${ }^{\circ}$ 16.402/16), com grande extensão das Zonas Especiais de Interesse Social.
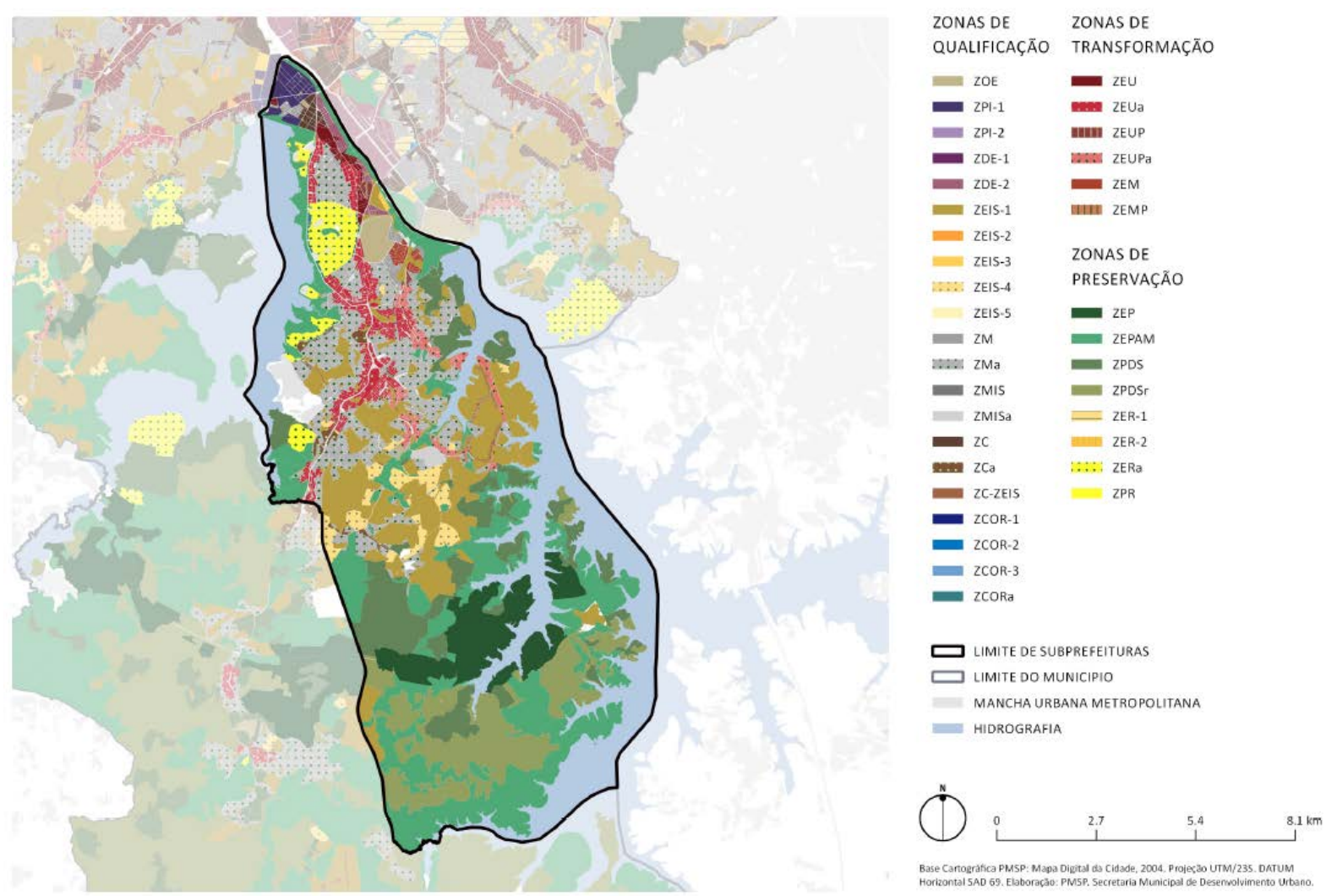

Fonte: Secretaria Municipal de Desenvolvimento Urbano - SMDU/SP, 2016.

Em 2001 foi instituída, por meio da Lei municipal nº 13.136, a Área de Proteção Ambiental Capivari-Monos (APA) e, em 2006, através da Lei municipal nº 14.162, a Área de Proteção Ambiental (APA) Municipal Bororé-Colônia, de modo que, hoje, aproximadamente 90\% da área correspondente à região de Capela do Socorro, que abrange 8,8\% do território do município, está inserida em área de proteção de mananciais ${ }^{63}$.

O bairro do Bororé é atravessado pelo reservatório da represa Billings, o que faz com que o mesmo permaneça, em parte, “ilhado”, por isso é conhecido como "Ilha do Bororé”. O bairro está localizado na Macroárea de Controle da Vulnerabilidade Urbana e Recuperação Ambiental e Zona de Preservação e Desenvolvimento Sustentável (ZPDSr). Em direção ao sul, na região do Rodoanel Mário Covas, incidem as Macroárea de Contenção Urbana e Uso Sustentável e Zona Especial de Proteção Ambiental (ZEPAM). Em 2006, foi instituída a Área de Proteção Ambiental (APA) Municipal Bororé-Colônia, com objetivo de preservar as

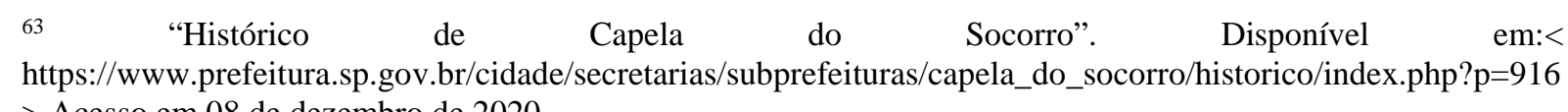
> Acesso em 08 de dezembro de 2020. 
nascentes, córregos e ribeirões que alimentam as represas Billings e Guarapiranga. Um aspecto interessante na legislação consiste na previsão da criação de um Programa Permanente de Educação Ambiental a ser efetuado por meio da atuação do poder público em conjunto com organizações locais da sociedade civil, por meio de um Conselho Gestor (art. 18, Lei n ${ }^{\circ}$ 14.162/06).

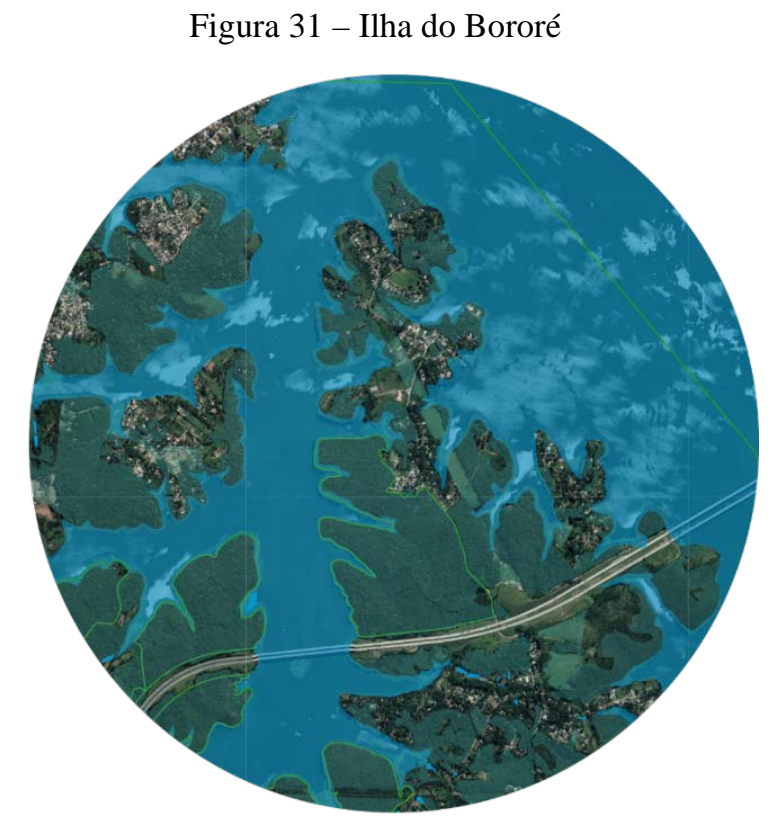

Fonte: Secretaria Municipal de Licenciamento - SMUL/SP, Secretaria do Verde e Meio Ambiente SVMA/SP e Google Earth - Ano de referência: 2015, 2016. Elaboração: autora.

Figura 32 - Ilustração da paisagem da travessia da represa por meio da balsa, na Ilha do Bororé

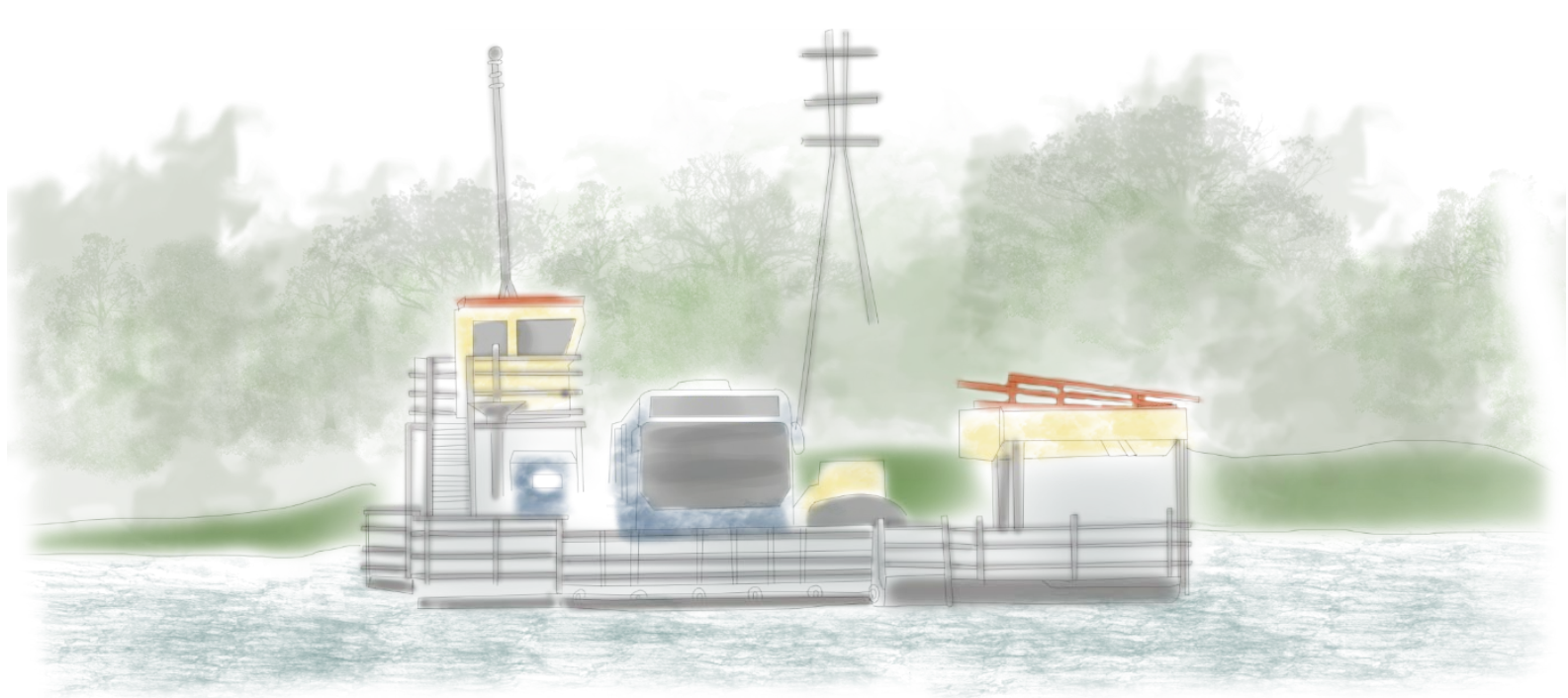

Fonte: idealização da autora, elaboração Camilla Ortega. 
Figura 33 - Ilustração da paisagem que desvela aspectos da ruralidade da Ilha do Bororé

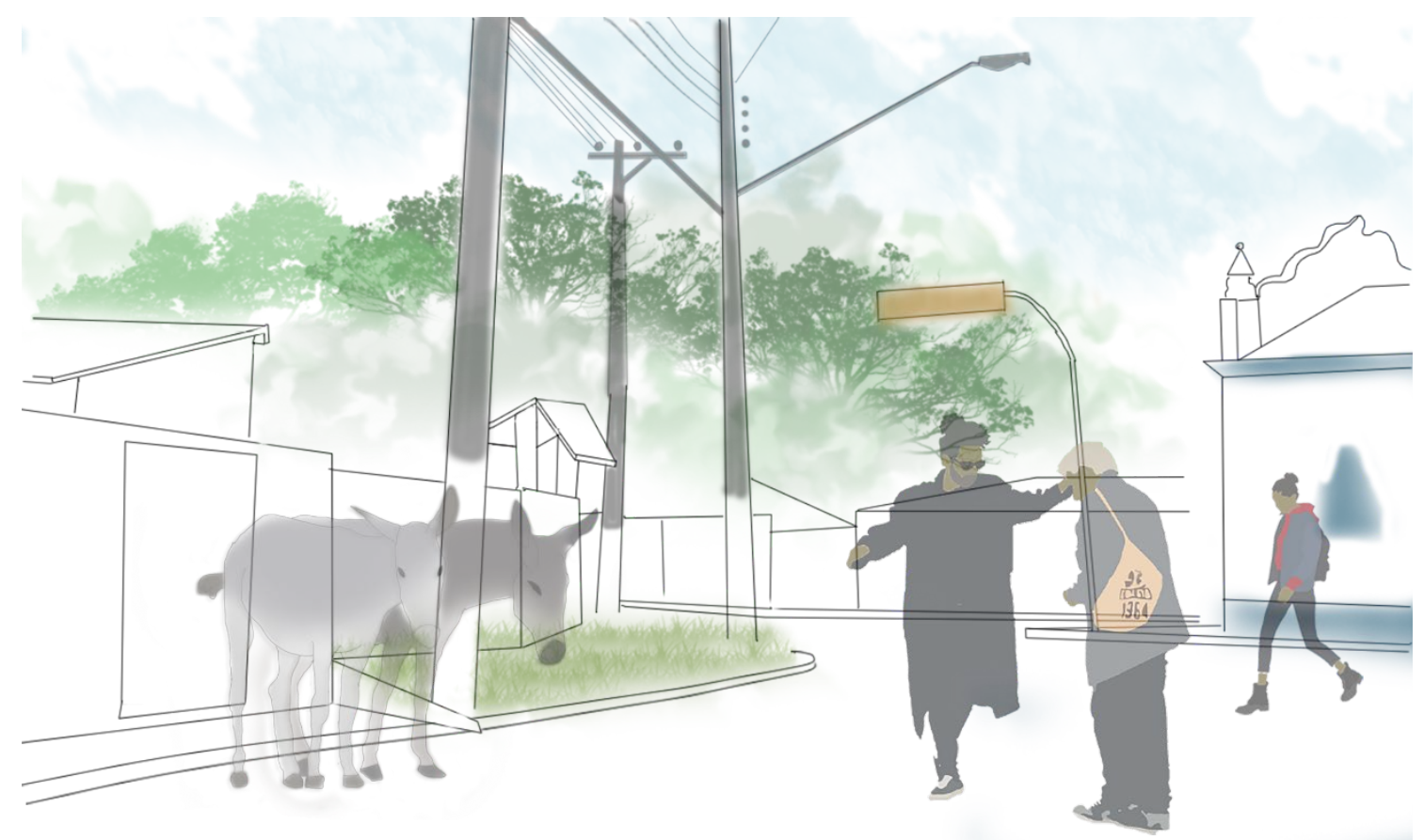

Fonte: idealização da autora, elaboração Camilla Ortega.

Além das características físicas e da incidência da legislação no território, é importante a compreensão da distribuição territorial dos equipamentos de cultura, educação e saúde, de modo que, relacionados aos aspectos socioeconômicas, pode-se compreender os “motivos” e “contrapontos territoriais” na “assinatura coletiva” (DELEUZE E GUATTARI, 1993) de “coletivos territorializados” (BASSANI, 2019) frente à desigualdade perante o restante das localizações da cidade. Nesse caso, as cartografias “oficias” dão um indicativo para compreender as presenças e ausências do território, em contraposição às dinâmicas observadas no cotidiano desses sujeitos coletivos. 
Mapa 12 - Equipamentos de Cultura no Grajaú

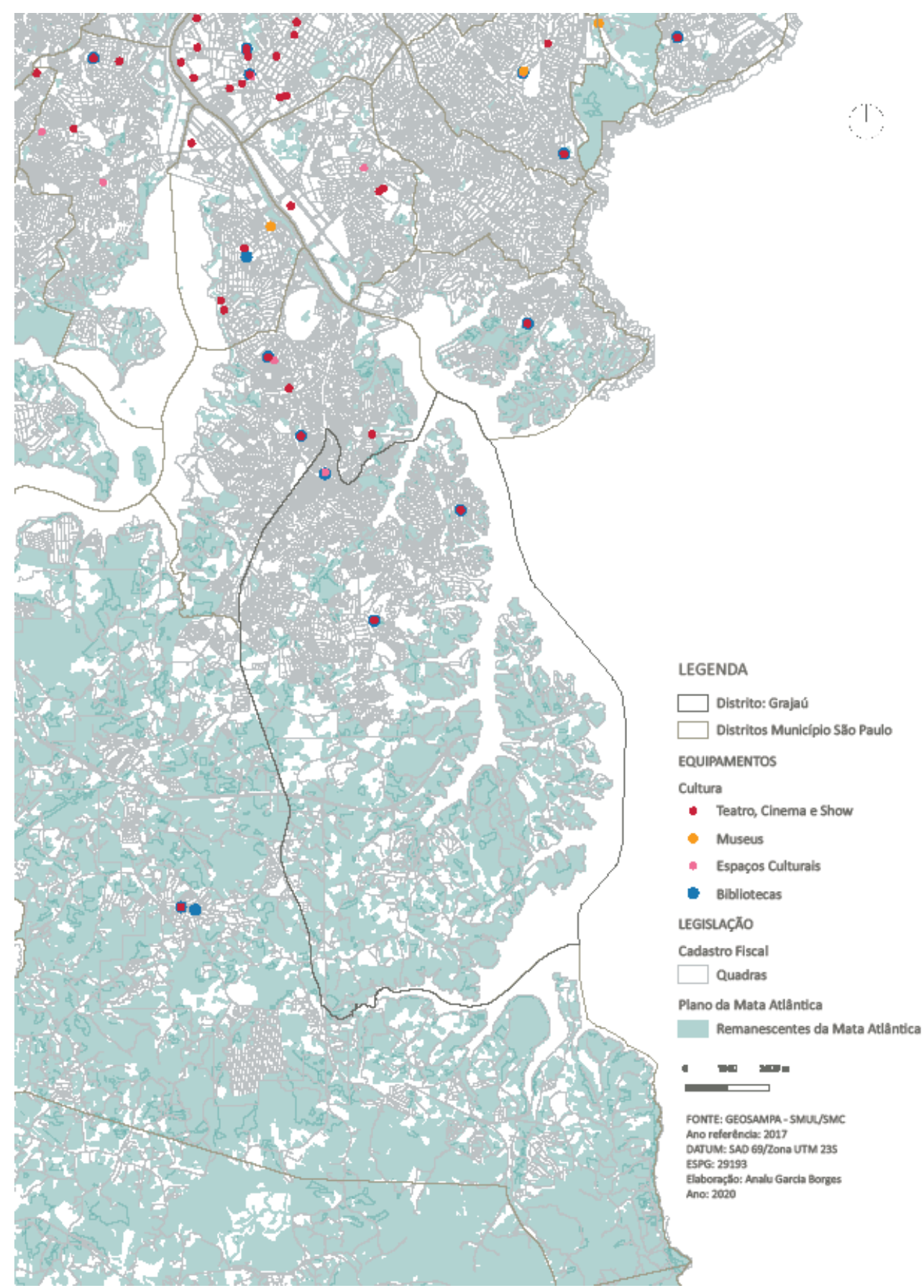

Fonte: Secretaria Municipal de Licenciamento - SMUL/SP e Secretaria Municipal de Cultura SMC/SP - Ano de referência: 2017. Elaboração: autora. 
Mapa 13 - Equipamentos de Saúde no Grajaú

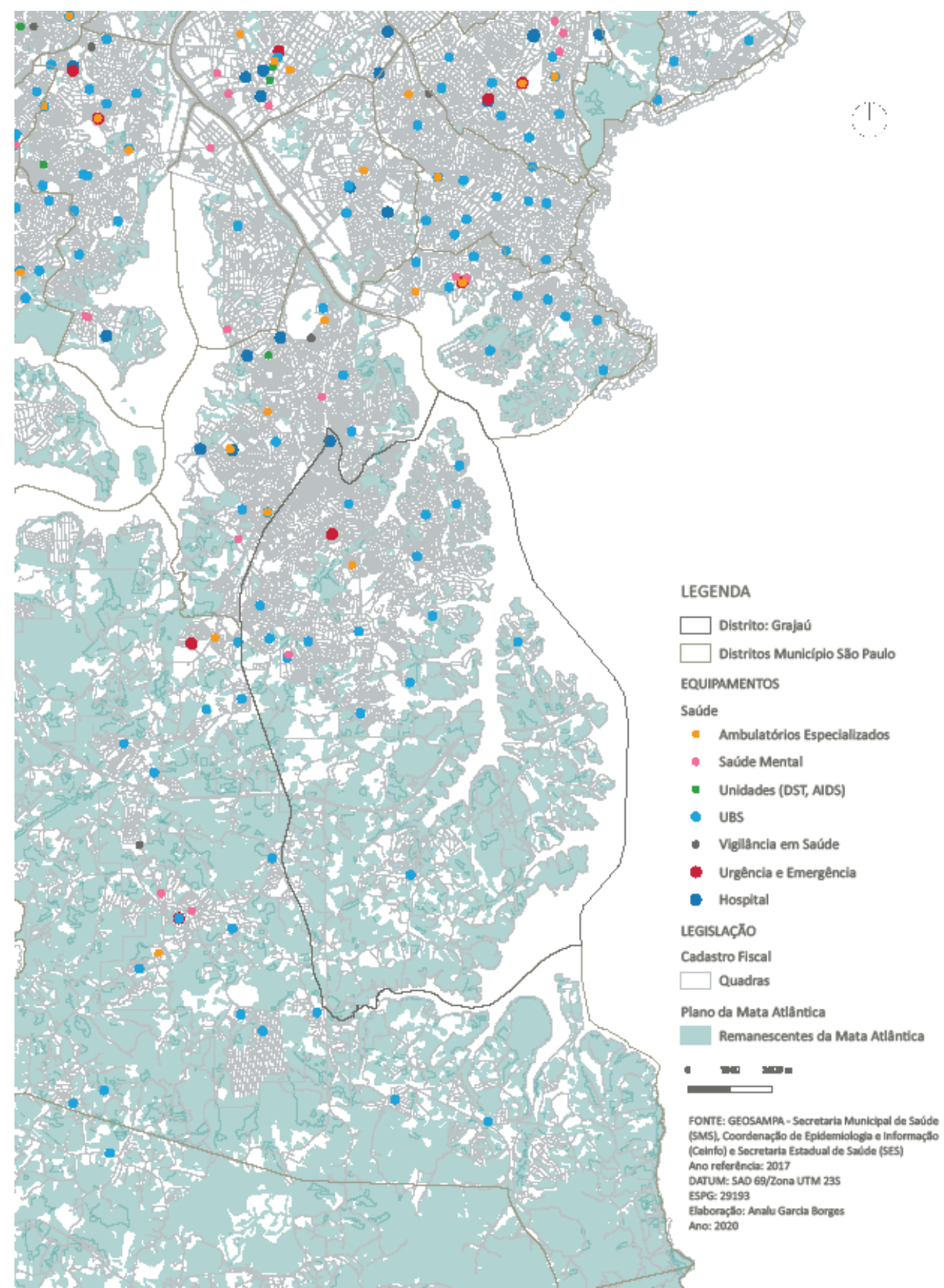

Fonte: Secretaria Municipal de Saúde (SMS/SP), Coordenação de Epidemiologia e Informação (CeInfo) e Secretaria Estadual de Saúde (SES) - Ano de referência: 2017. Elaboração: autora. 


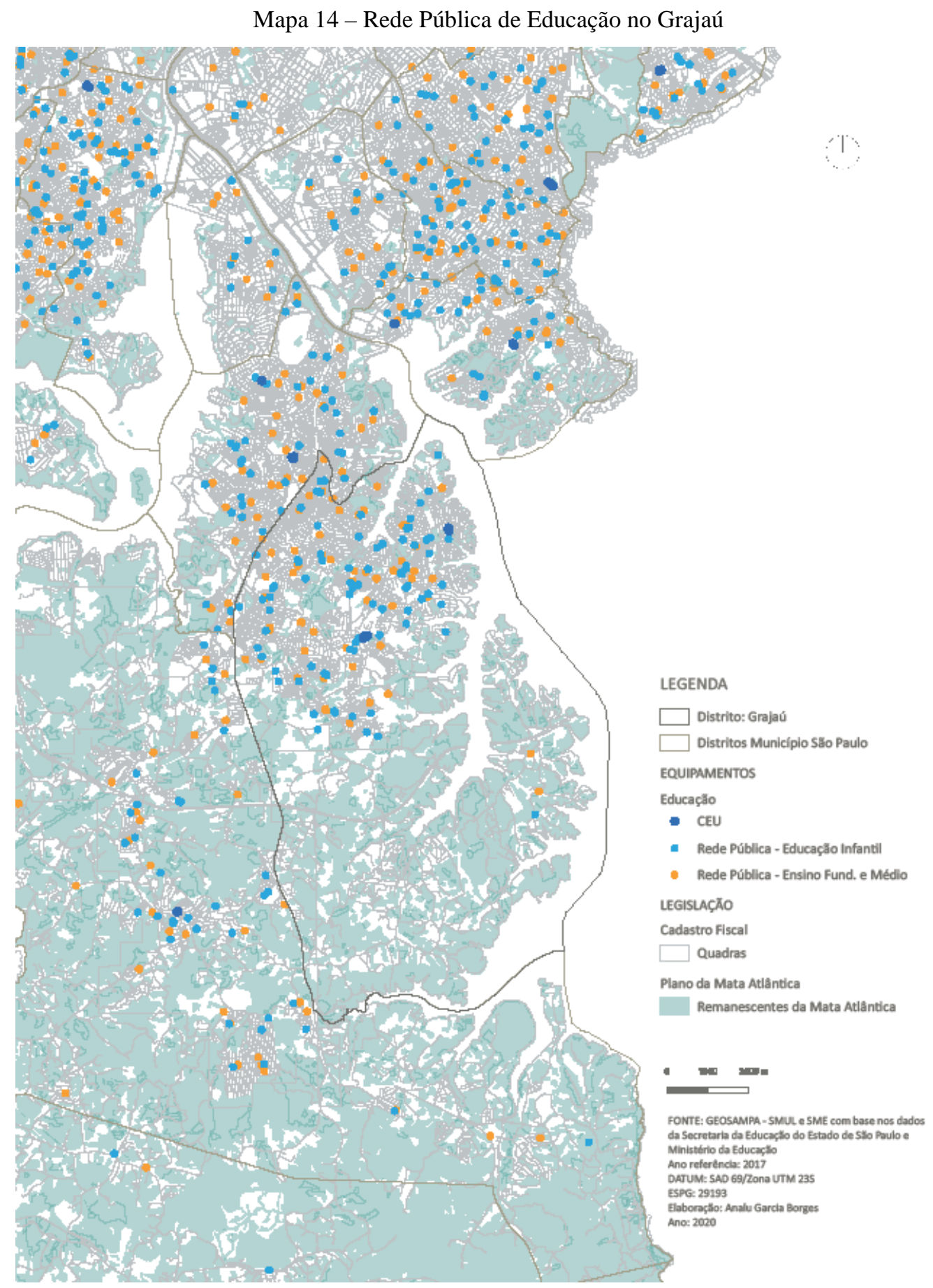

Fonte: Secretaria Municipal de Licenciamento - SMUL/SP e Secretaria Municipal de Educação SME/SP, com base nos dados da Secretaria da Educação do Estado de São Paulo e Ministério da Educação - Ano de referência: 2017. Elaboração: autora.

A distribuição desigual de equipamentos e serviços em territórios periféricos tem sido uma das frentes de luta por melhor qualidade de vida na metrópole, por meio da organização comunitária e da mobilização política. Desse modo, a Unidade Básica de Saúde (UBS) Alcina Pimentel, assim como a Associação dos Amigos do Bororé (AMIB), a Casa Ecoativa, os 
moradores que tomam frente das questões da Igreja de São Sebastião e a Escola Estadual Professor Adrião Bernardes são pontos de importância no território, pois constituem campos de força associativos e comunitários em busca de melhoria das condições de vida. Esses sujeitos coletivos vêm constituindo suas marcas no território por meio de ações notadamente no âmbito da cultura e da educação, como o coletivo eco cultural Casa Ecoativa e a E. E. Professor Adrião Bernardes, os quais fizeram parte do trabalho de campo da pesquisa.

Figura 34 -Pontos do território do Bororé que emergiram das falas dos participantes durante o trabalho de campo

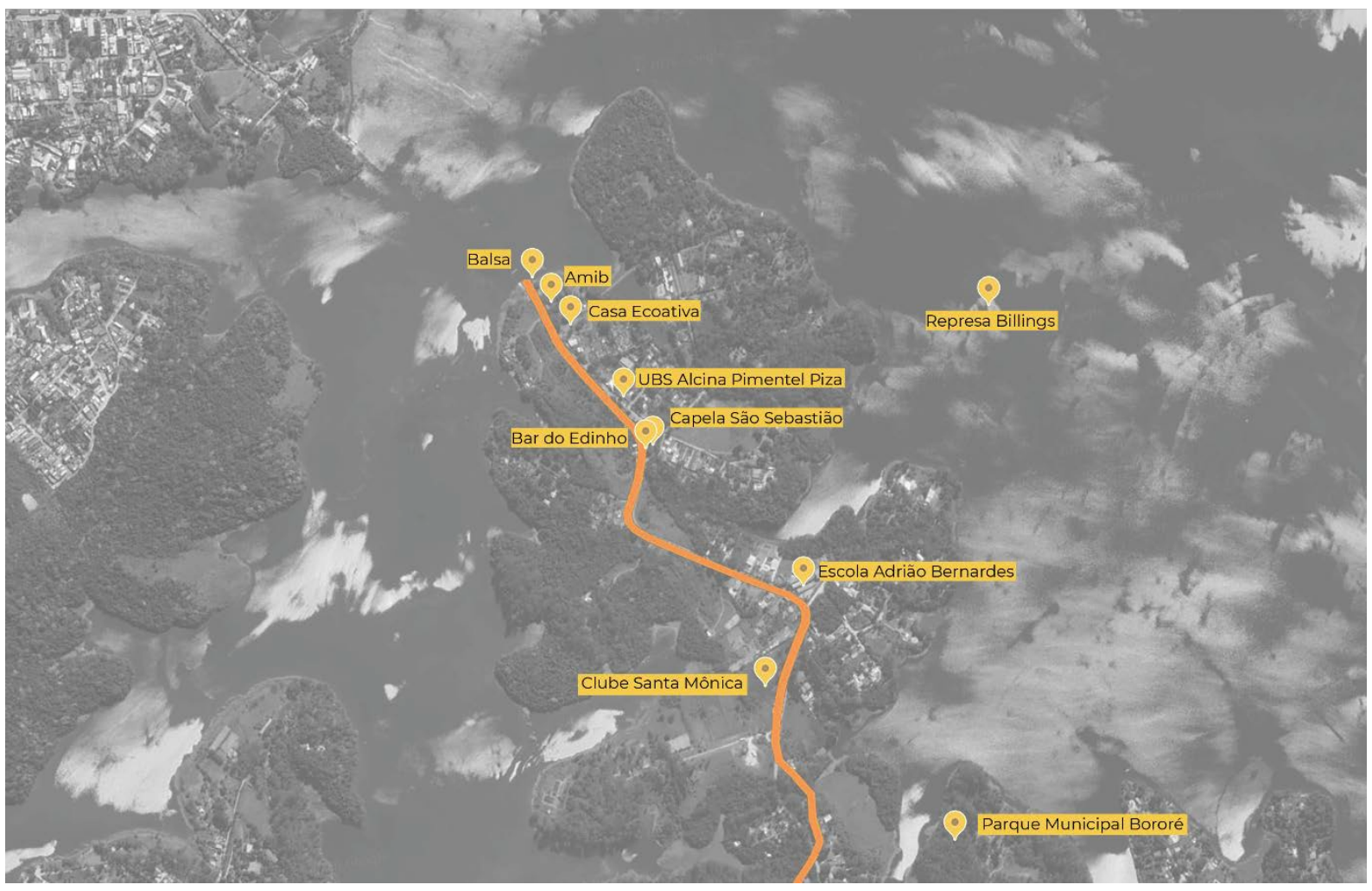

Fonte: idealização da autora, elaboração de Camilla Ortega, com base em imagem do Google Earth.

\subsection{Ilha do Bororé: uma cidadania em despertar, o exercício pedagógico no território para conscientização}

As marcas do território aliadas a ação de sujeitos organizados coletivamente e territorializados constituem o que alguns desses grupos denominam de "memória viva”, pois suas práticas (re)contam, por meio expressões artísticas e políticas, o povoamento da região, as contradições representadas pela implementação da represa Billings, as questões conflitivas entre a condição estrutural de desigualdade e pobreza, com a consequente ocupação das áreas 
de proteção aos mananciais, bem como a atual conscientização pela preservação do meio ambiente.

Figura 35 - Placa na entrada da ilha do Bororé, após a travessia da primeira Balsa

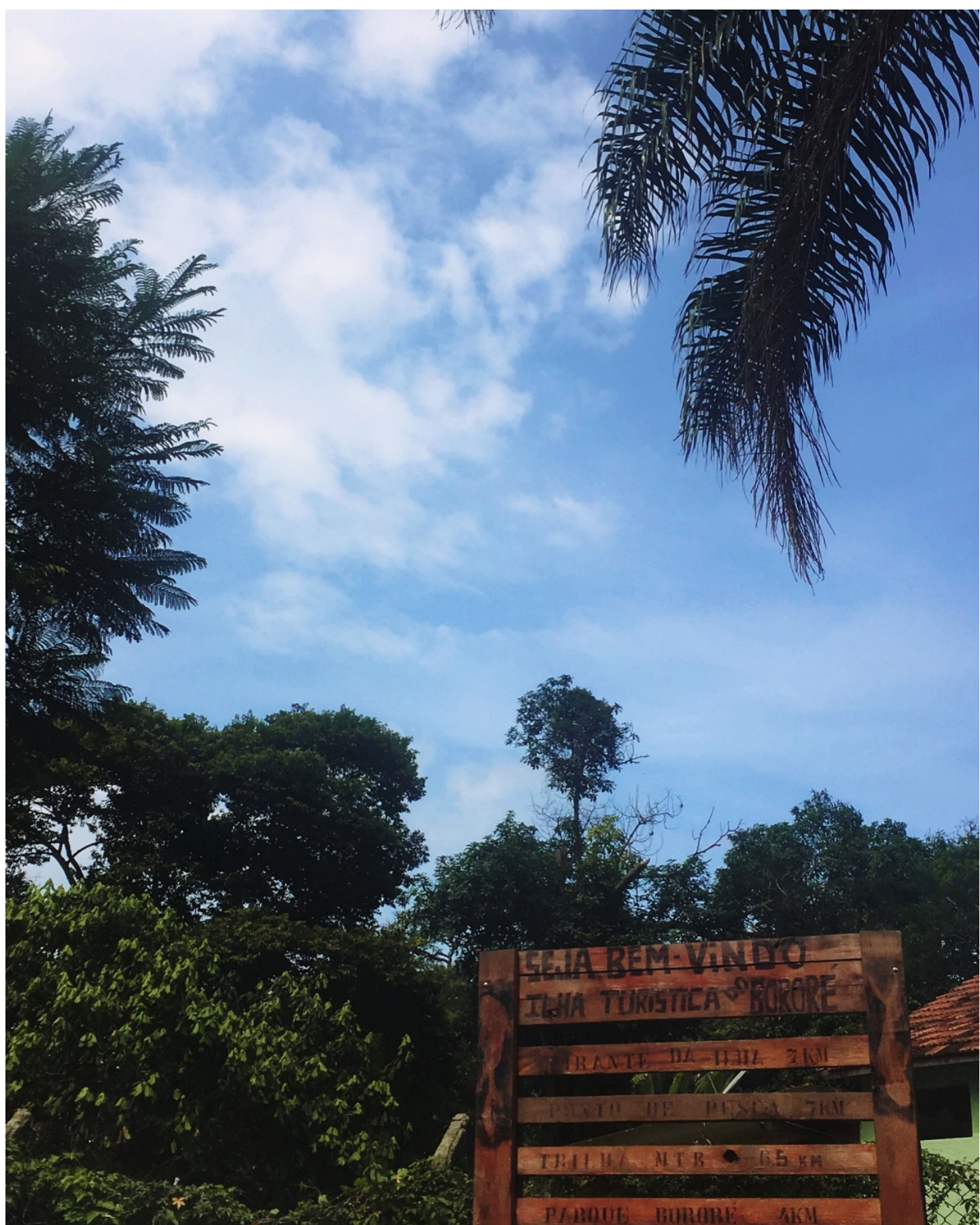

Fonte: acervo pessoal.

É, o Bororé ele é um território singular na cidade de São Paulo, tem inúmeros desafios como qualquer outra Periferia. É uma zona rural, é um território Rural, mas a travessia da balsa deixa um lugar único tanto para coisas boas, quanto para coisas ruins, 
principalmente o acesso, ele acaba sendo dificultoso, mas também o acesso faz com que não se desmate tudo. Embora tenha bastante o uso irregular do solo, aumenta a população, mas nada comparado a qualquer outro bairro na cidade de São Paulo.

Então a dificuldade de chegar é a mesma que inibe também as pessoas virem.

(PARTICIPANTE 8, entrevista concedida a Analu Garcia, 2020).

Figura 36 - Chegada da Primeira Balsa na ilha do Bororé

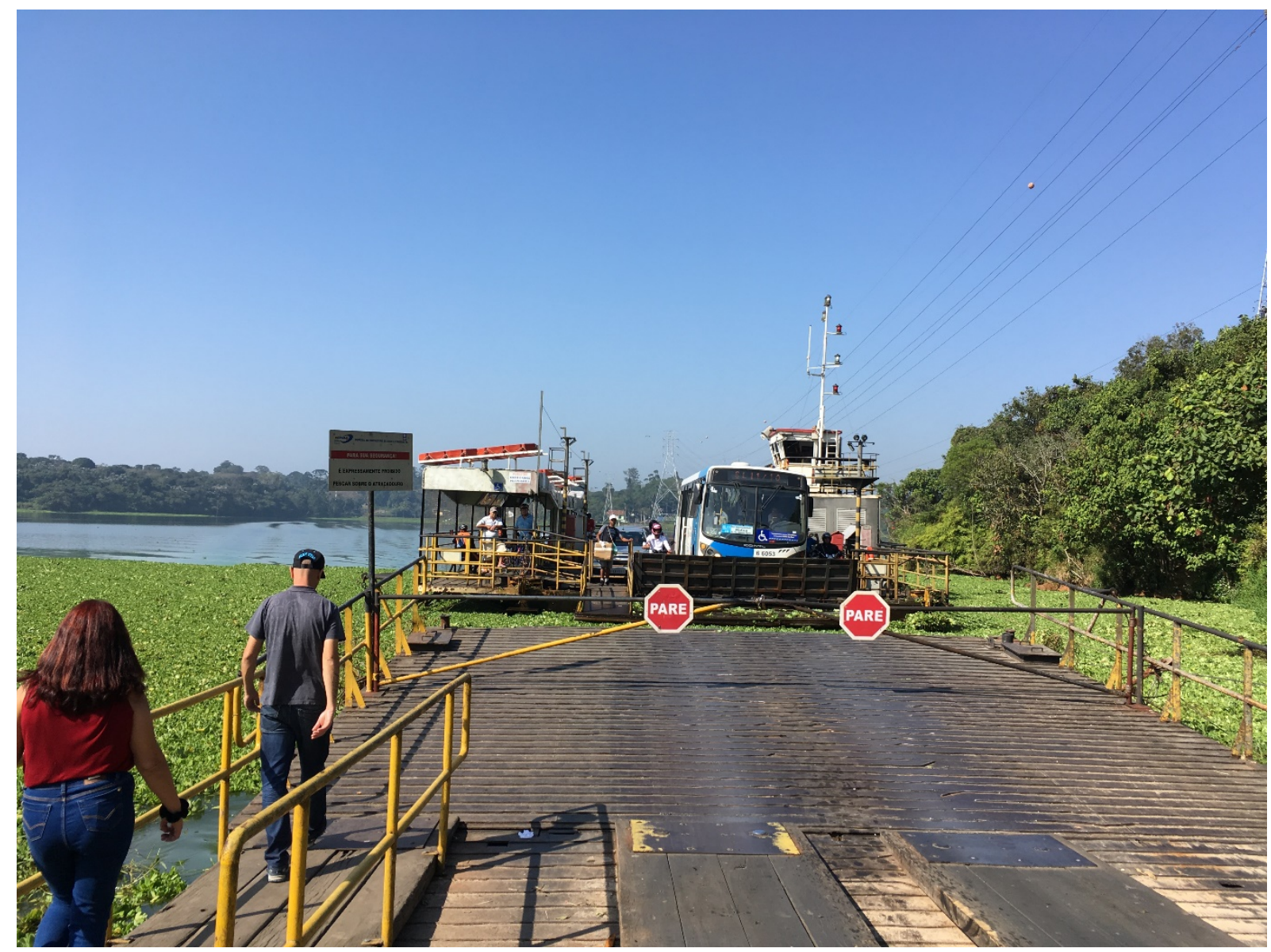

Fonte: acervo GeMAP/USP.

A questão da ocupação das áreas de mananciais gera conflitos e, inclusive, estigmatização das populações que vivem no local, o que se percebe em algumas falas como “habitações clandestinas”, “ocupação desordenada”. Contudo, a conscientização crescente da população de que essa condição não é uma culpa imputável a nível pessoal e individual, mas sim uma questão histórica e estrutural relacionada ao acesso à terra e à moradia no Brasil, também aponta para o surgimento de “contra-narrativas” por parte da juventude, organizada em coletivos de cultura e meio ambiente, interferindo sutil e progressivamente na subjetividade de moradores mais antigos. 
E isso tem que ser desmistificado porque o conflito existe, né, mas como que a gente lida com esse conflito? Então por isso que a gente tenta colocar todo mundo na roda na ilha para discutir o território e não significa que não vai ter conflito [...] A gente propõe a gente trocar ideia, sabe [...] e a gente foi vendo de como é importante fazer uma conta-narrativa. Então quando o Tião Rocha fala do Copo Cheio, da pedagogia do Copo Cheio, beleza, eu vou sair aqui na frente de casa e vou olhar um buraco gigantesco na rua, [...] porque ela não tem asfalto, mas eu vou ficar falando disso toda hora? Eu vou ficar falando de outras coisas que são legais, que ao mesmo tempo se eu chegar aí no final da rua que tem uma mina de água e é um morrozinho maravilhoso e que eu sei que tem um monte de gente que daria o braço para morar num lugar assim. Então que que eu costumo falar? Que não é importante falar das coisas que são difíceis, mas falar a conta-narrativa e o que tem de legal é tão importante quanto!

(PARTICIPANTE 8, entrevista concedida a Analu Garcia, 2020).

No trecho acima o "contra-narrativas" emerge como uma categoria de discurso de valorização e orgulho das potencialidades da periferia. Nesse caso, o discurso de valorização que os coletivos procuram fazer vem das potencialidades educativas do território e de seu trunfo perante o restante da cidade: a presença de vegetação abundante e de água. Inserida em uma APA, a ilha do Bororé é uma área rural com a presença de atividades de agricultura e permacultura. Ademais, a cultura é um ponto forte dessa “marca territorial”, pois os coletivos como o Imargem, a Casa Ecoativa, o Navegando nas Artes e diversos outros do Grajaú possuem uma intensa programação cultural na região ${ }^{64}$.

A partir da segunda década deste século surgem projetos organizados pela comunidade em torno das dimensões da cultura, da educação e do meio ambiente. Em 2012 coletivo Imargem concebe o "Mural-Memória Ilha do Bororé - A história do bairro", um mural de graffiti na Estrada Velha do Bororé, próximo à Igreja São Sebastião, com relatos visuais sobre a constituição do bairro. O tema da memória tem sido tratado de forma sistemática por coletivos e artistas dos territórios periféricos, como forma de promover a construção de identidade e pertencimento, em contraposição à estigmatização que esses grupos sofreram durante sua inserção no espaço urbano da metrópole décadas antes, reproduzindo questões históricas de exploração relacionadas à população negra e indígena, ancestralidade marcante da região sul.

\footnotetext{
${ }^{64}$ Para ver o levantamento realizado sobre a produção cultural no Grajaú, cf. RODRIGUES, 2017.
} 
Figura 37 - Mapa de Intervenções e Processos do Projeto Imargem no Grajaú em 2011, 2012 e 2013. Material compartilhado com a Casa Ecoativa e utilizado em suas atividades pedagógicas

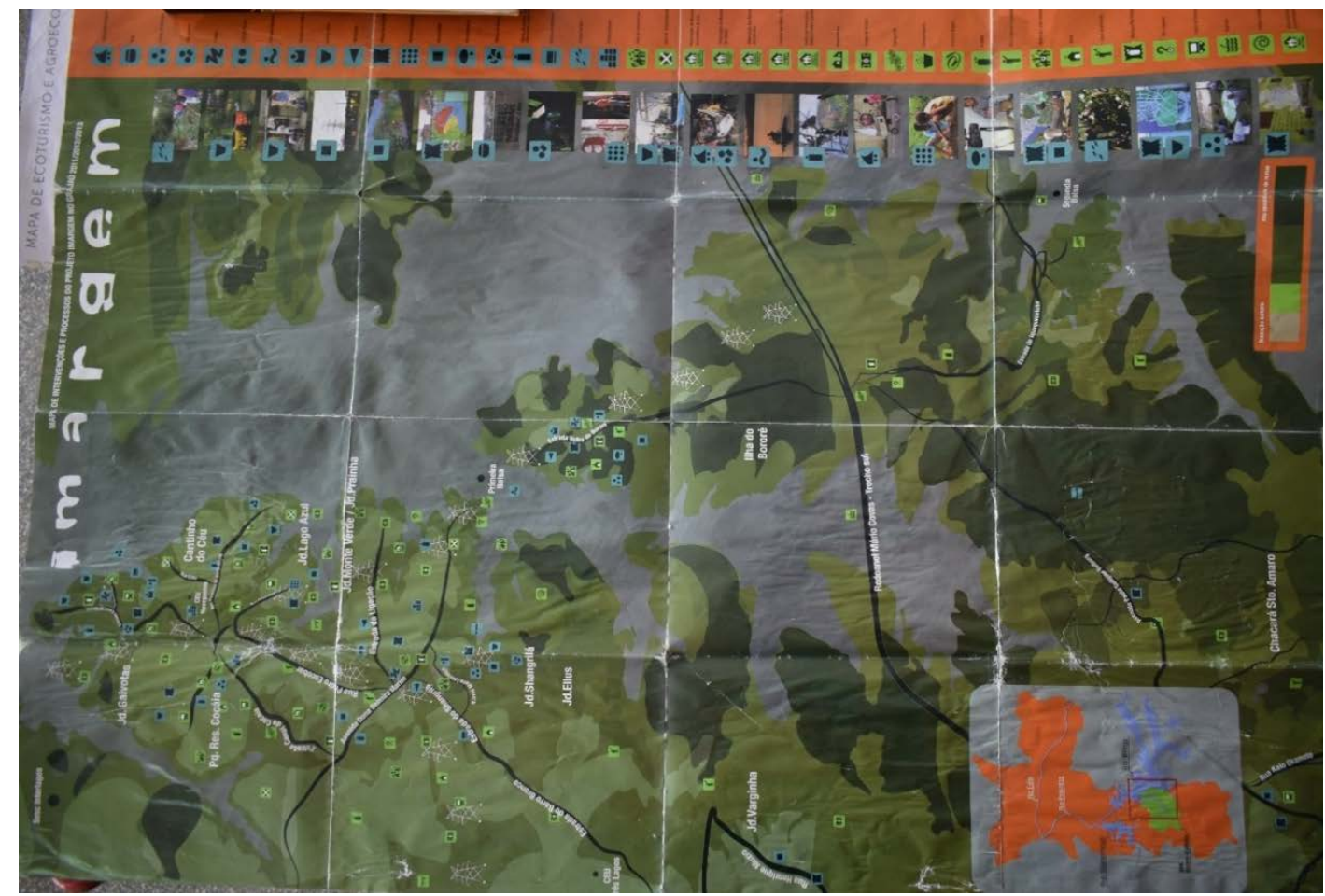

Fonte: Projeto Imargem, foto de acervo pessoal.

Figura 38 - Verso do Mapa de Intervenções e Processos do Projeto Imargem no Grajaú em 2011, 2012 e 2013 , com destaque para o Mural-Memória elaborado em 2012 na Ilha do Bororé

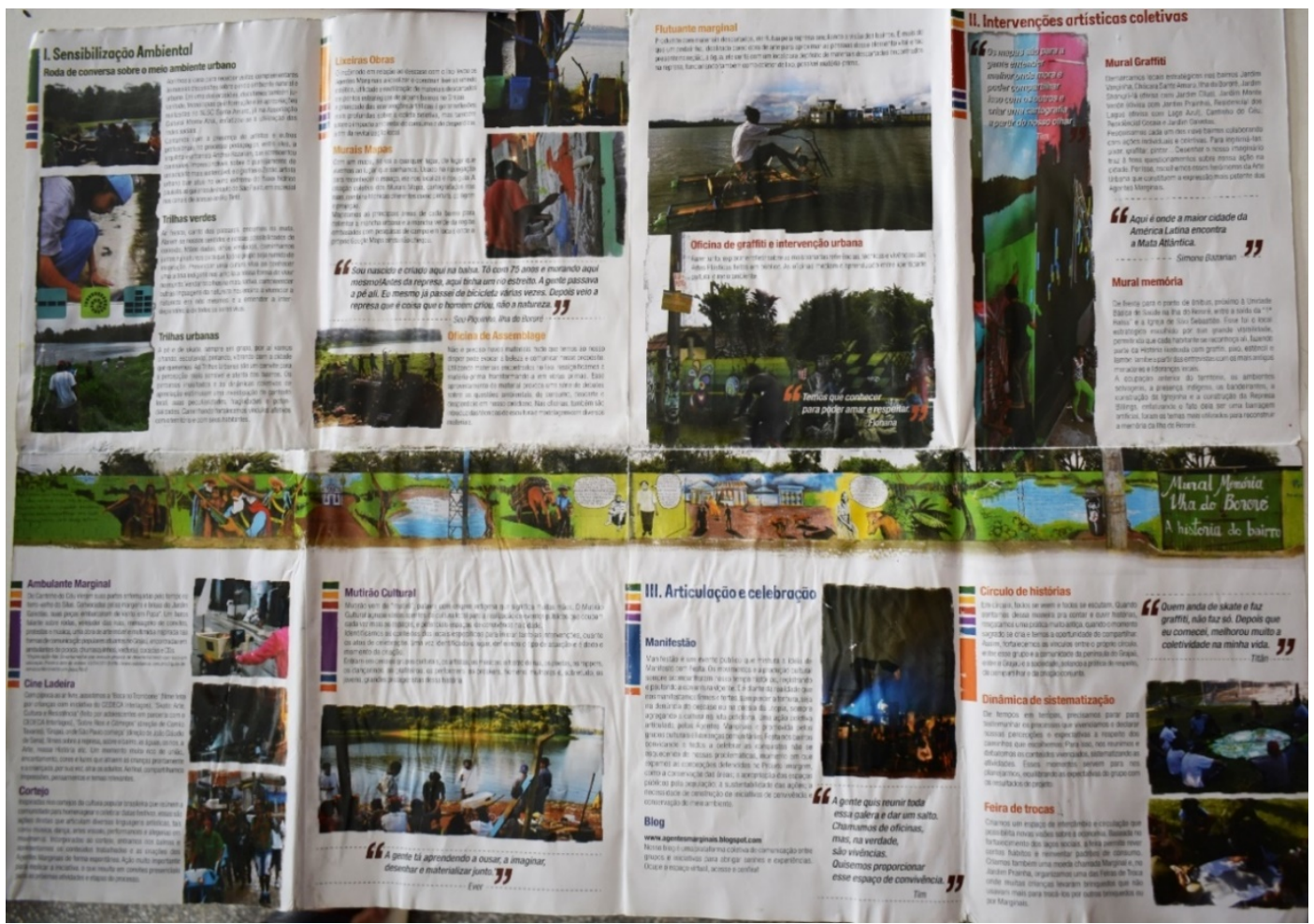

Fonte: Projeto Imargem, foto de acervo pessoal. 
Figura 39 - Trecho do Mapa de Intervenções do projeto Imargem, com destaque para os Murais Mapas e a metodologia de trabalho de campo, com entrevistas a moradores antigos da região do Grajaú

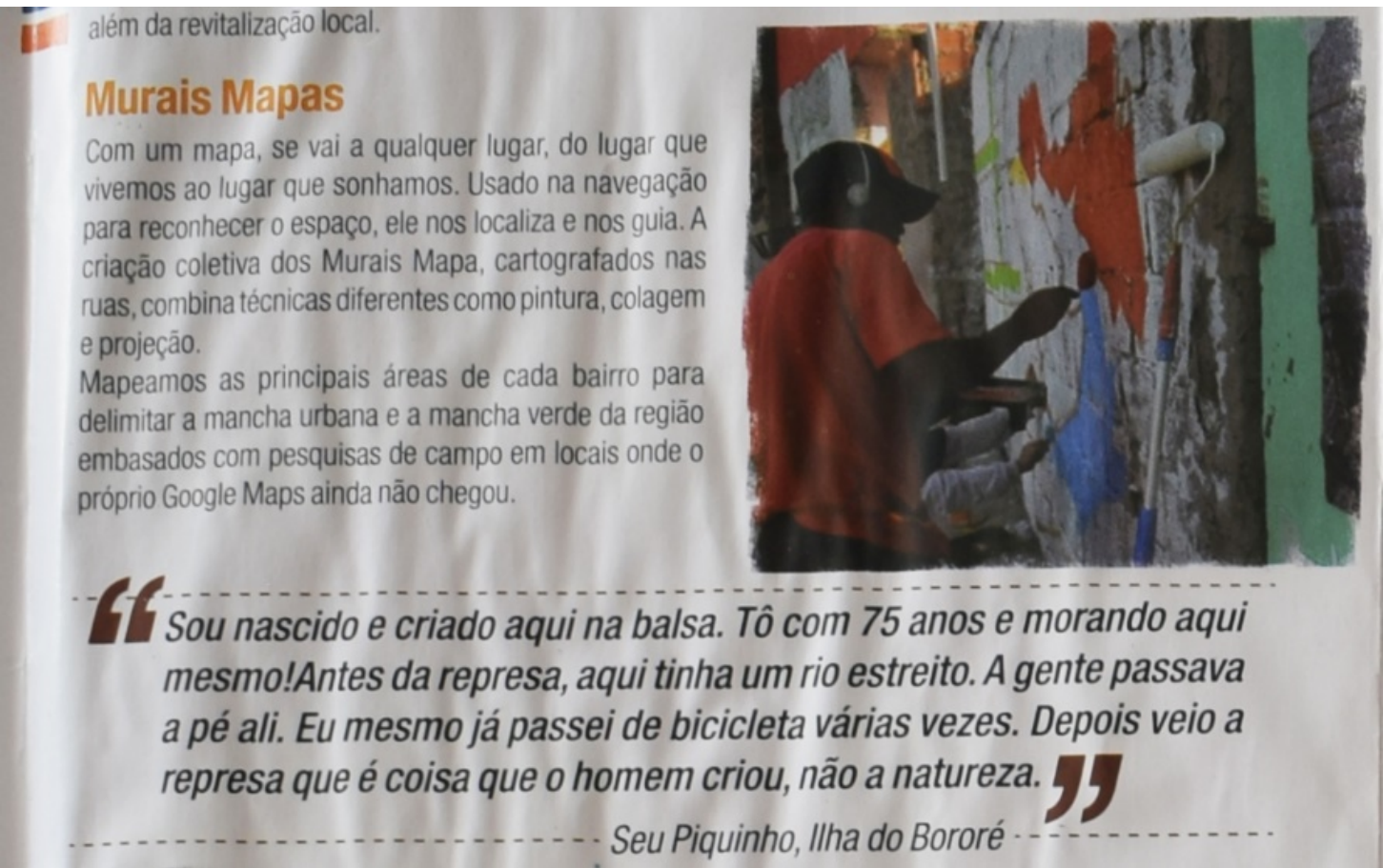

Fonte: Projeto Imargem, foto de acervo pessoal.

Figura 40 - Mural Mapa na Ilha do Bororé

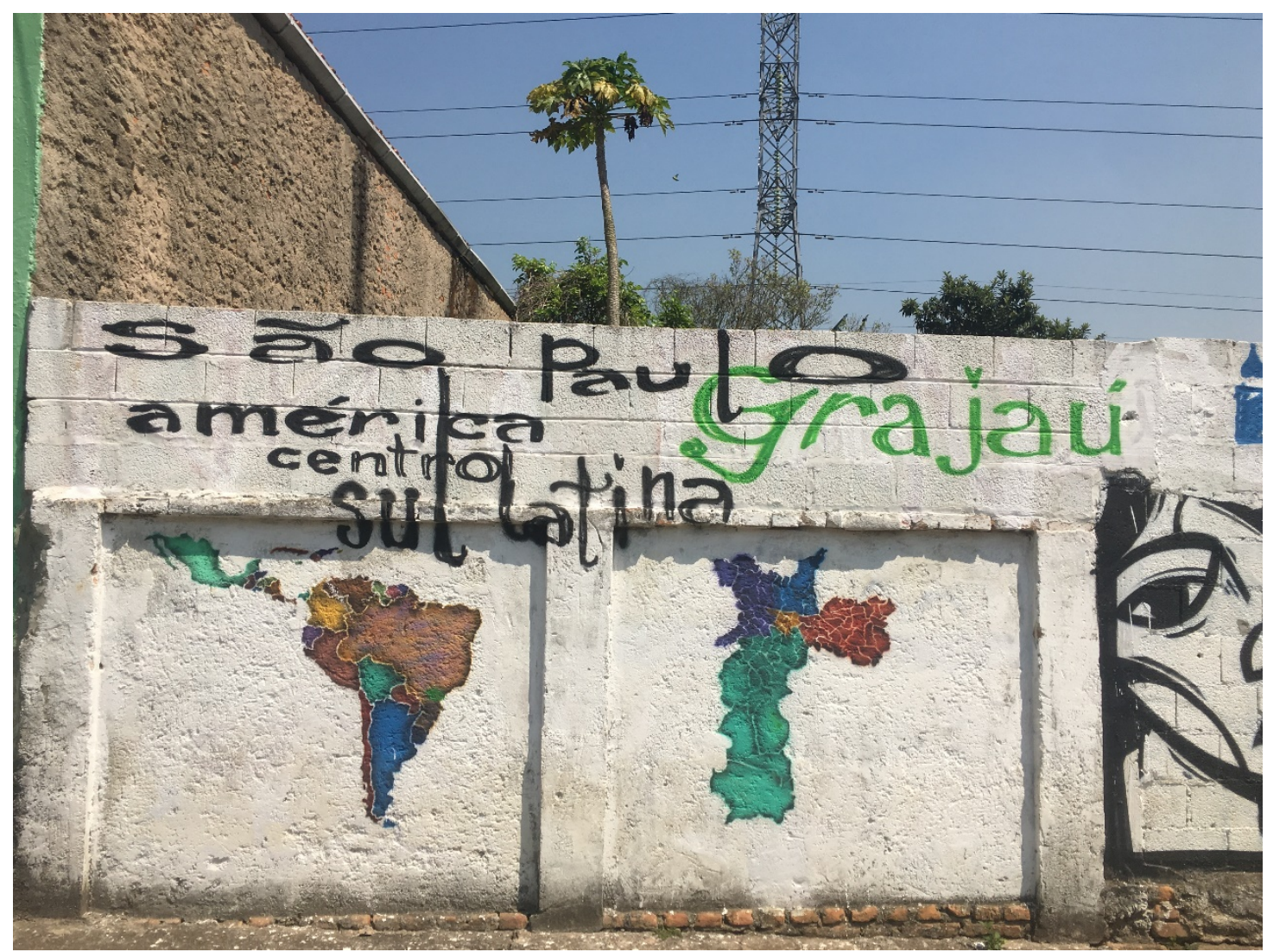

Fonte: Projeto Imargem, foto de acervo pessoal. 
Figura 41 - Foto do Mural-Memória, elaborado em 2012 pelo coletivo Imargem, na Ilha do Bororé

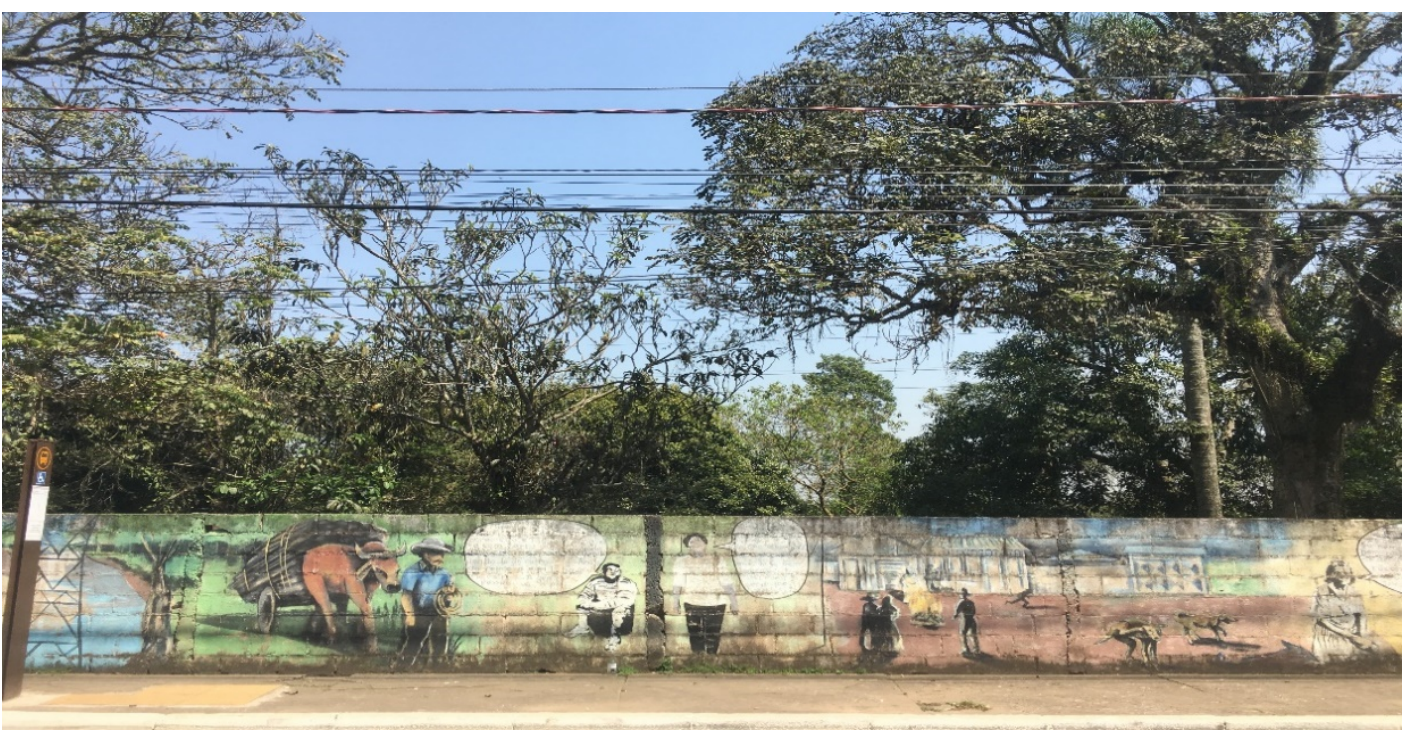

Fonte: acervo pessoal.

A Igreja da Comunidade São Sebastião do Bororé, tombada pelo CONPRESP em 2013, é um ponto importante no território, pois em seu entorno já foram realizados muitos festejos e cortejos, tradição entre os moradores mais antigos da comunidade. Desse modo, ela pode ser considerada um $\operatorname{lugar}^{65}$ de identidade da comunidade da ilha, notadamente dos moradores mais antigos.

Figura 42 - Capela de São Sebastião e a paisagem com aspectos rurais do cotidiano da ilha do Bororé

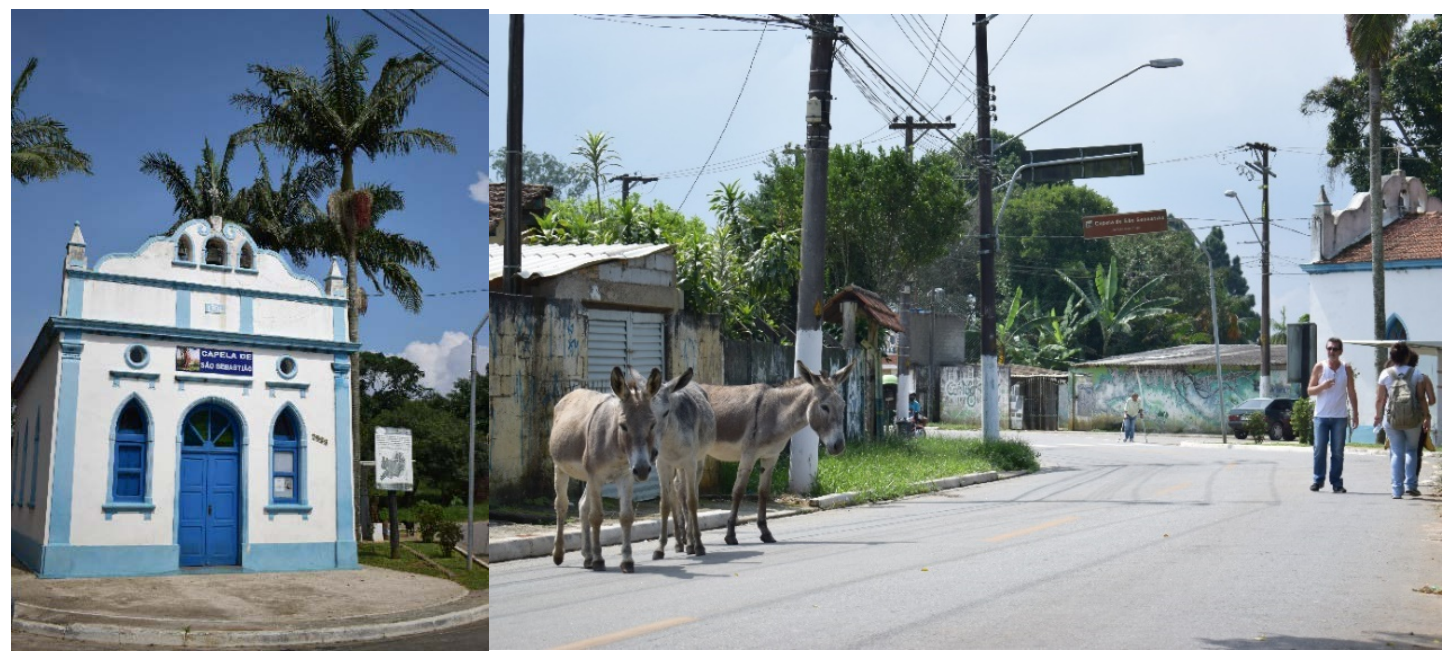

Fonte: acervo pessoal.

\footnotetext{
${ }^{65}$ Segundo Marcelo de Souza (2020), “lugar” e “território” são conceitos “inter-relacionados” com a materialidade do espaço, mas que não se limitam apenas a ele, pois são definidos de acordo com as diferentes relações e interações com e a partir dele. O lugar tem como central dimensão cultural-simbólica, "envolvendo as identidades, a intersubjetividade e as trocas simbólicas, por trás da construção de imagens e sentidos dos lugares enquanto espacialidades vividas e percebidas, dotadas de significado” (SOUZA, 2020, p. 115), enquanto território está diretamente ligado à dimensão política.
} 
Figura 43 - Quadro com fotos das atividades comunitárias na ilha do Bororé em torno da Igreja São Sebastião, expostas no Bar do Edinho

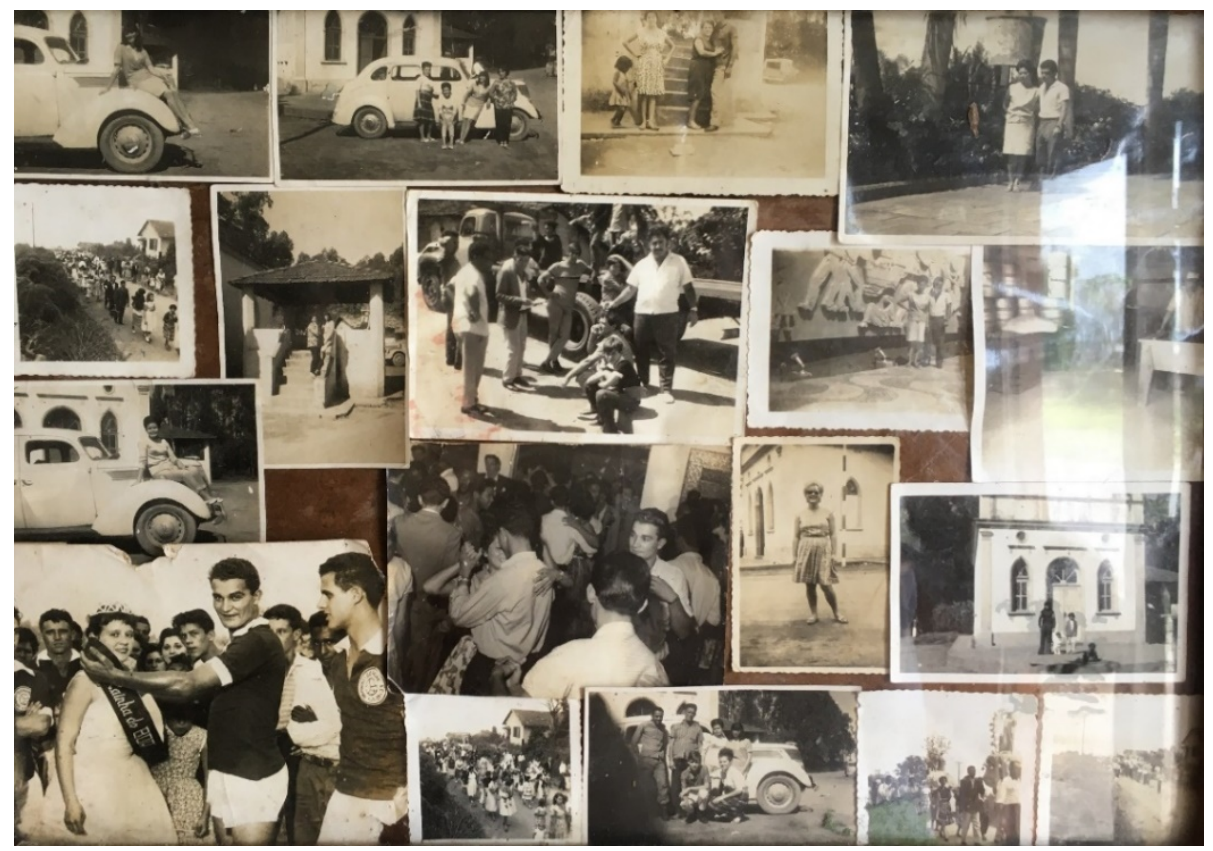

Fonte: Grupo de Estudo de Mapografias Urbanas (GeMap/USP).

Figura 44 - Fotos dos festejos da comunidade do Bororé ao redor da Igreja de São Sebastião e do atual Bar do Edinho

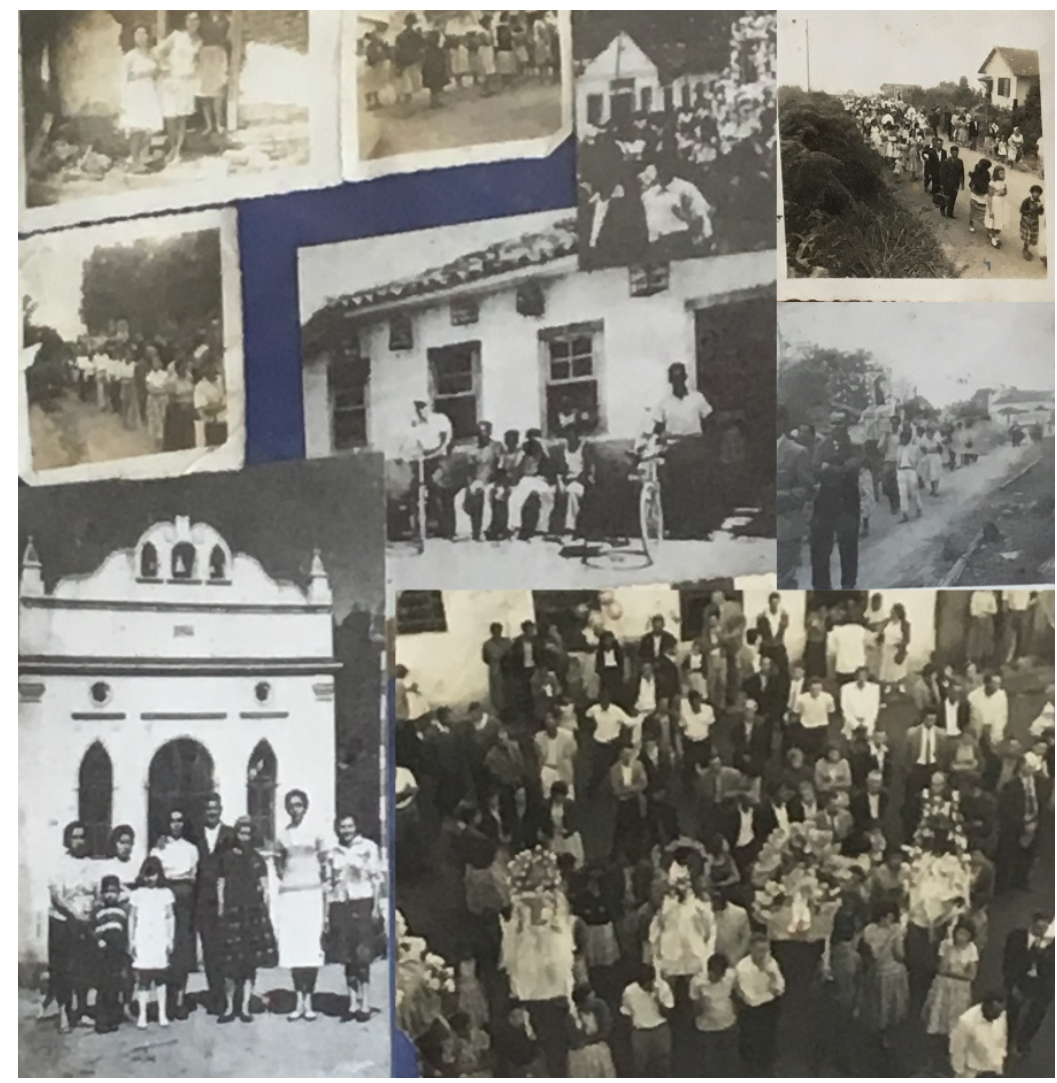

Fonte: Grupo de Estudo de Mapografias Urbanas (GeMap/USP). 
3.2.1 A casa Ecoativa e o ativismo ecocultural: construindo narrativas de um território educador

A comunidade do Bororé vem constituindo de maneira progressiva uma ação comunitária para buscar melhorias para o bairro. A casa Ecoativa é um coletivo eco-cultural localizado no território do Bororé, criada na década de 1990 por meio da ação comunitária dos moradores que reivindicavam um espaço comunitário e cultural para o bairro. O lugar funcionava como contra turno escolar, onde as crianças podiam desenvolver atividades comunitárias e recreativas.

E aí eu era atendido, eu era essa criança que fazia a atividade do Adrião Bernardes e atividades na Ecoativa. Tinha evento, tinha coisa com permacultura, com capoeira, tinha literatura, então é o histórico grande da comunidade tentar se organizar.

(PARTICIPANTE 8, entrevista concedida a Analu Garcia, 2020).

Figura 45 - Casa Ecoativa, na Ilha do Bororé, 2019

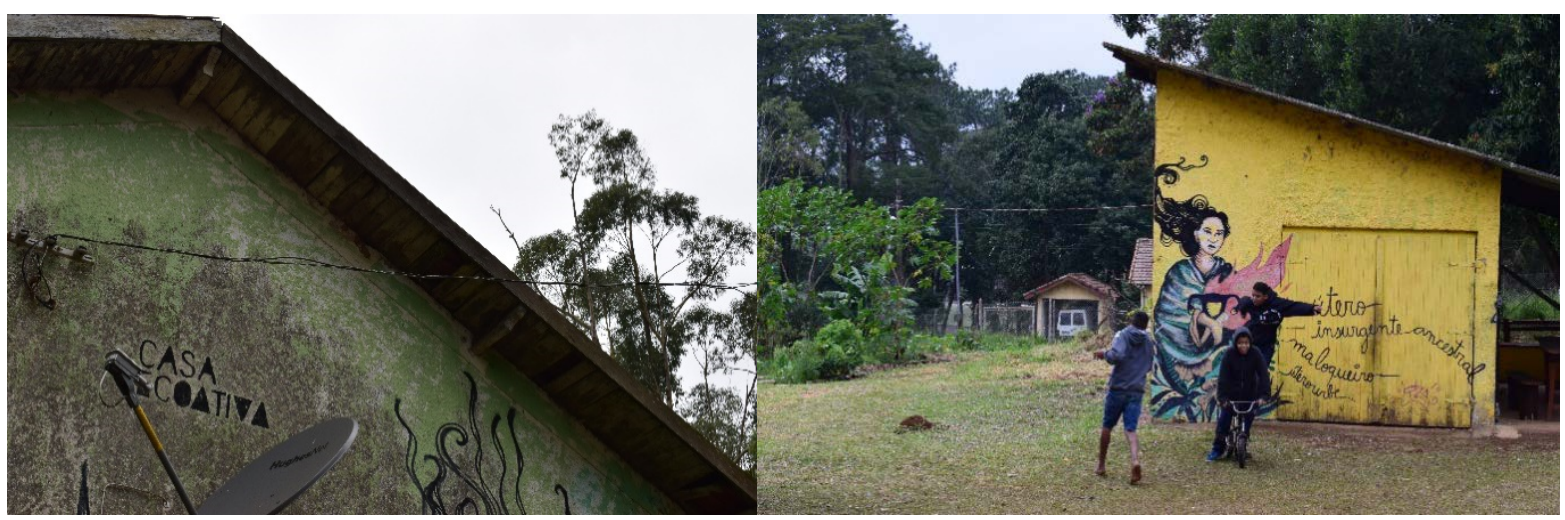

Fonte: acervo pessoal.

O centro cultural encerrou suas atividades em 2006, retomando-as a partir de 2013 por iniciativa de moradores que desfrutaram do seu espaço na década de 1990. A partir desse momento as expressões culturais intensificaram-se na ilha do Bororé, por meio de atividades dos coletivos locais, como o Imargem e a Ecoativa, em parceria com a Escola Estadual Adrião Bernardes.

[...] eu também tenho um "start" de voltar para mais para o território, "pow! Posso trabalhar com arte, cultura”. Trabalhei, fiquei quatro anos trabalhando na Vila Mariana, pegando o busão "pá”, estudando, 2:30h de busão para ir, 2:30h para voltar, 
[...] e vi um solo de vários coletivos se organizando, a partir daí os coletivos organizando e aí vi uma cena para voltar e falar "não, quero desenvolver um projeto aqui”. Voltei para escola e propus os projetos de horta e fui aos pouquinhos do nada 2013, 2012/2011 fui participando e fui cria desses coletivos culturais, né, como o próprio Imargem e foi curtindo essa ideia até a gente poder caminhar e ver uma economia criativa, um lugar de desenvolver projetos como educador, como produtor cultural no Grajaú. E aí você descobre que o território é muito legal, porque até então a gente saia do território para tentar fazer alguma coisa, mas você tava sacando uma rede que você fala "não, pera aí! A referência é meu próprio lugar, o meu próprio território é mega referência”. E aí, eu até então não conhecia tanta gente porque a informação não chegava. Mas a partir dessa descoberta você vira a chave e fala "não, eu consigo fazer, eu consigo desenvolver" isso faz mais sentido para você. Acaba fazendo mais sentido porque você vê o desenvolvimento local.

(PARTICIPANTE 8, entrevista concedida a Analu Garcia, 2020).

A Ecoativa possui importância nas articulações socioterritoriais no Bororé, pois defende pautas como a preservação ambiental e o desenvolvimento local autossustentável, com a constituição de “territórios-rede” (HAESBAERT, 2019) no âmbito do Bororé, do Grajaú e da cidade de São Paulo, estabelecendo parcerias com a Escola Estadual Professor Adrião Bernardes e com outros coletivos importantes na região, como o Imargem $^{66}$, a Rede PermaPerifa $^{67}$ e a UniGraja ${ }^{68}$. O desenvolvimento de práticas de agroecologia visa o desenvolvimento territorial de base local e a conscientização da população local, como também de outros grupos sobre o território do Bororé e sua importância ambiental para a cidade de São Paulo. Dentre as atividades organizadas pela Ecoativa constam aquelas voltadas para a permacultura e alimentação orgânica, bem como atividades culturais para as crianças e jovens da ilha no contra turno escolar e período de férias.

66 “O Projeto Imargem é uma intervenção multidisciplinar que, reunindo arte, meio ambiente e convivência, pretende enfrentar o isolamento das comunidades que vivem às margens da Represa Billings, região do Grajaú, São Paulo”. Disponível em: http://imagemdamargem.blogspot.com/. Acesso em 9 dez 2020.

${ }^{67}$ A Rede PermaPerifa atua nos bairros da periferia por meio de mutirões que auxiliam nas organização de atividades de permacultura e bioconstrução.

68 Apresentação da página @unigraja no Facebook: “O que a quebrada te ensina para a vida? A UniGraja Universidade Livre do Grajaú nasce para juntar potencialidades e apontar caminhos possíveis para quem quer transformar nossa realidade e viver do que o território tem a oferecer”. Disponível em: https://www.facebook.com/unigraja/. Acesso em 12 dez 2020. 
Figura 46 - Roda com o mestre em cultura popular brasileira Tião Carvalho na Casa Ecoativa e crianças brincando no balanço de pneu, 2019

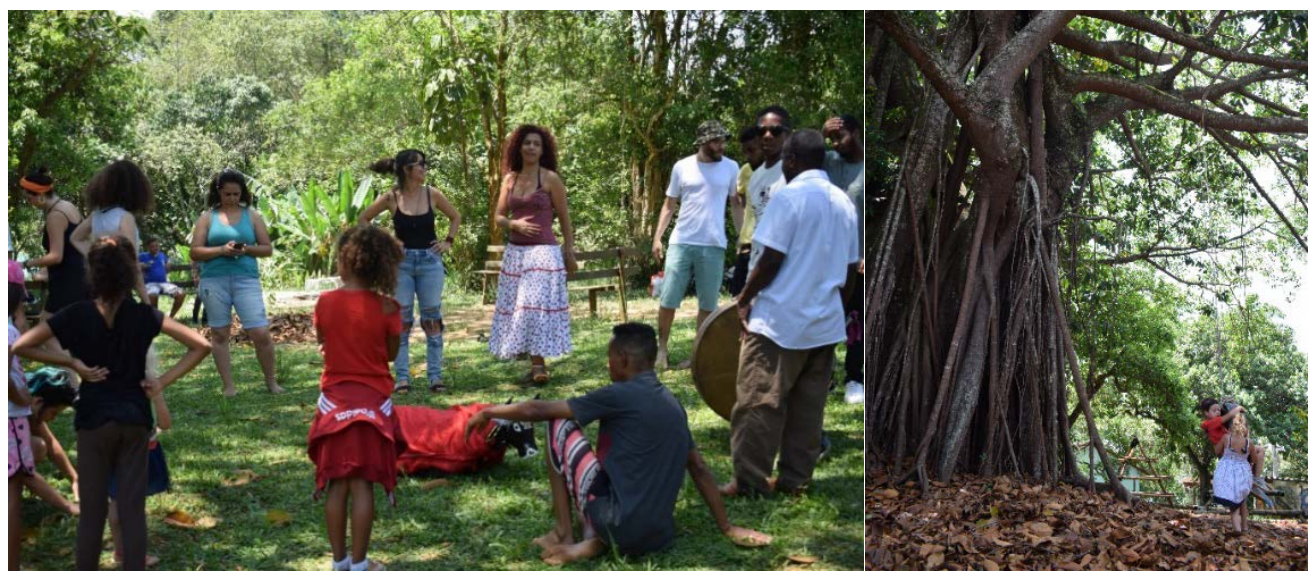

Fonte: acervo pessoal.

Figura 47 - Roda com o mestre em cultura popular brasileira Tião Carvalho na Casa Ecoativa, 2019

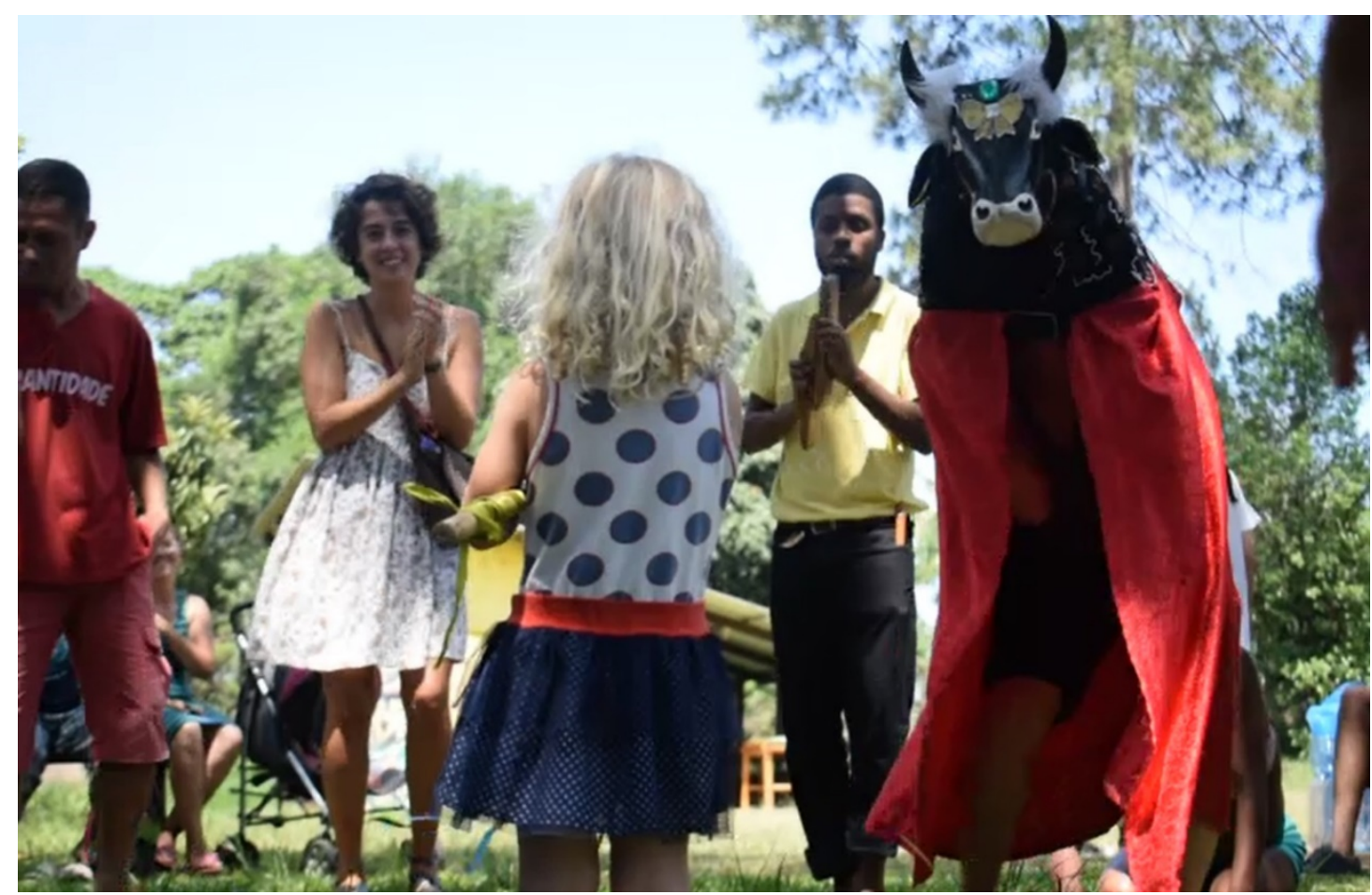

Fonte: acervo pessoal. 
Figura 48 - Atividade de “cartograffiti” com as crianças da ilha no programa Ecoativa Férias, 2019

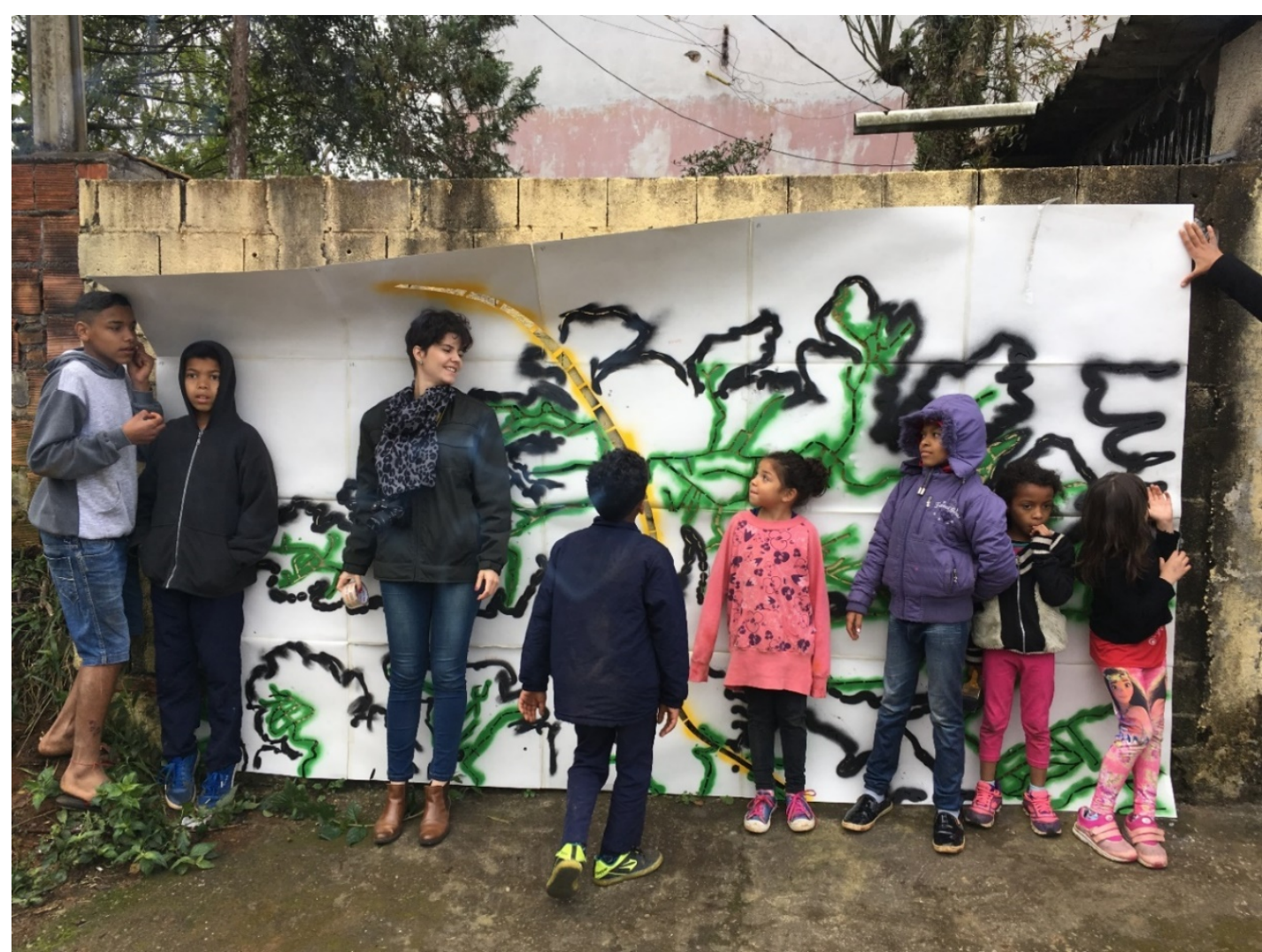

Fonte: acervo GeMAP/USP.

Figura 49 - Pintura do mapa do Bororé com tinta de terra, durante o programa Ecoativa Férias, 2019

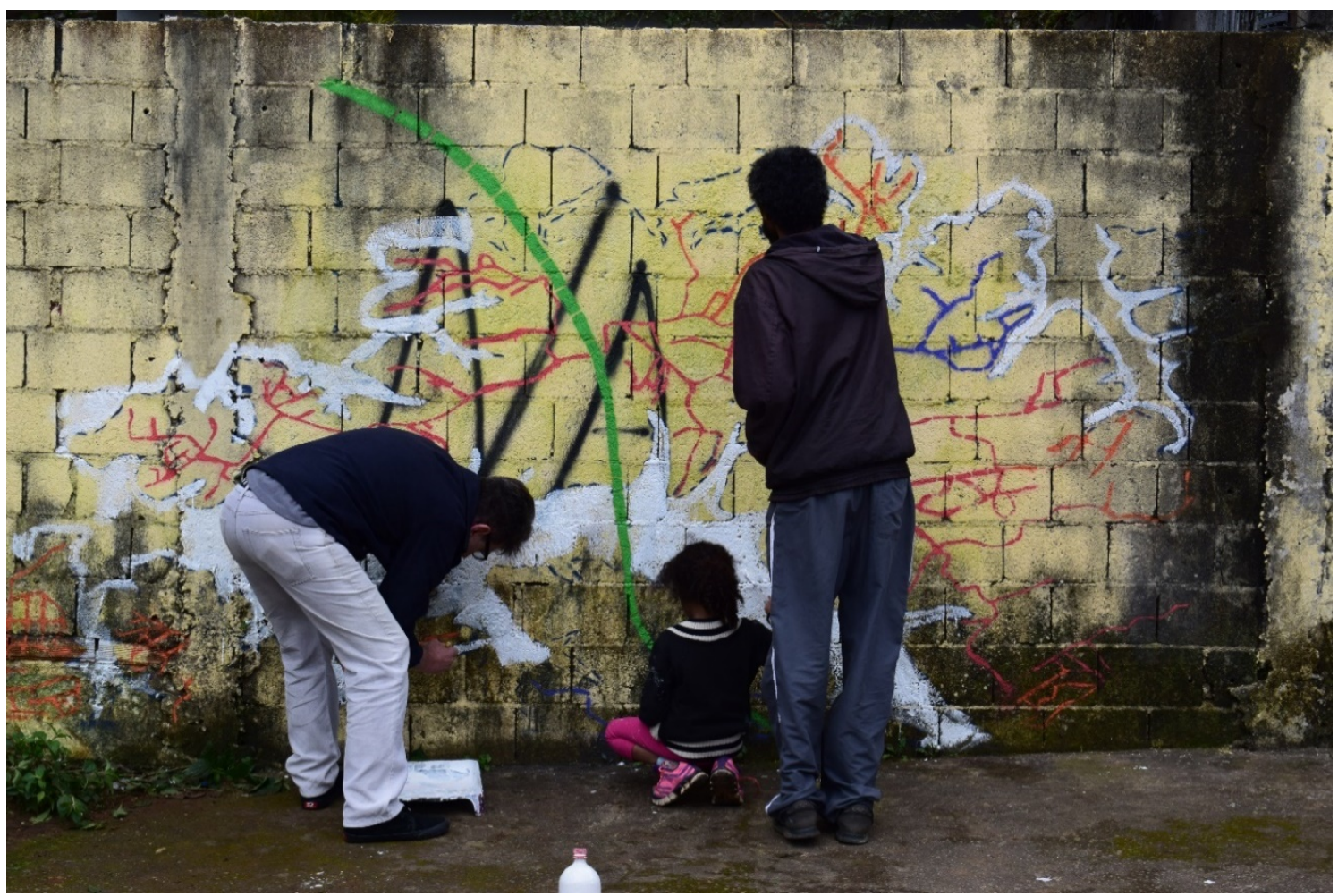

Fonte: acervo pessoal. 
Figura 50 -Mapa do Bororé pintado durante a atividade da Ecoativa Férias, 2019

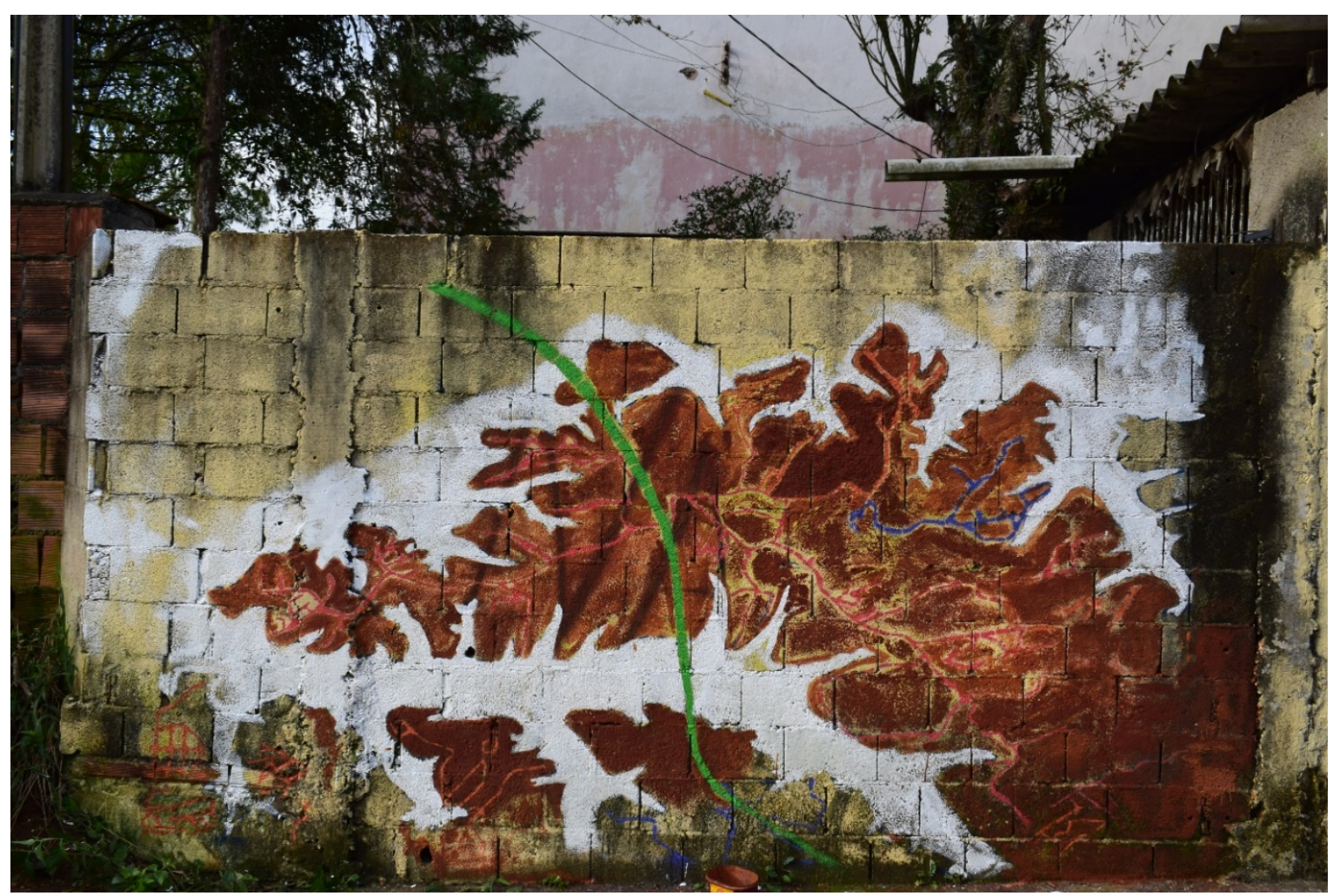

Fonte: acervo pessoal.

Nas práticas educativas da Casa Ecoativa, o território está sempre envolvido, seja por meio das atividades de agroecologia, como também nos discursos, cujo conteúdo busca uma problematização também territorial: a questão dos territórios periféricos e a ação estético política dos “sujeitos periféricos” (D’ANDREA, 2020). As discussões sobre o território permeiam várias camadas, desde as questões relacionadas ao meio ambiente, à produção ancestral da agricultura na ilha, bem como as questões culturais geracionais, buscando enfatizar aspectos da memória, como os festejos em torno da Capela de São Sebastião, bem como as manifestações mais recentes relacionadas ao graffiti. Nesse ponto as práticas podem ser analisadas mediante a abordagem proposta por Raffestin. Segundo Raffestin (1993, p. 143), “o território se forma a partir do espaço” e a apropriação concreta ou simbólica pelos agentes consiste na territorialização do espaço. Desse modo, a apropriação do espaço “dado” e a (re)significação por meio de atividades práticas, como o trabalho com a terra e com a arte, bem como a inovação de linguagens e reorganização de fluxos de informação por meio de discursos compartilhados de valorização das expressões desses agentes periféricos configuram novos territórios - territórios de autonomia, de conscientização e de práxis. 
Ademais, o aspecto marcante de educação popular comunitária nas ações do coletivo emerge dos processos de solidariedade e ação integrada com outros agentes do território na escala do bairro e da ligação afetiva e identitária sobre o lugar. Como já destacado, o Bororé apresenta é uma área rural e seus moradores compartilham a percepção da ausência de infraestrutura, de equipamentos públicos e atenção do Poder Público ao local, razão pela qual, além da questão do reconhecimento, a questão do desenvolvimento sustentável está sempre presente nas narrativas sobre o território.

[...] a Ecoativa é um projeto da associação de moradores [...] e é uma organização que tá ali desde 1994 então já é difícil com, imagina sem [...] as maiores lutas da comunidade de base é a balsa que é pequena, a mudança de uma balsa maior, as ruas que estão esburacadas, o leite que não chega, a perua que não passa na escola, que não chega, então as lutas mais duras são travadas todos os dias, né.

(PARTICIPANTE 8, entrevista concedida a Analu Garcia, 2020).

As atividades desenvolvidas pelos coletivos de cultura no Bororé apresentam características predominantes de educação comunitária, conceito apresentado no capítulo 02 deste trabalho, que, segundo Gadotti (2012, p. 18), "pode ser entendida como uma das expressões da educação popular, mediante a qual se busca melhorar a qualidade de vida dos setores excluídos, através dos movimentos populares, que estão organizados em grupos de base, comunidades, municípios etc.”

As articulações em rede que a Ecoativa estabelece com outros agentes do território do Bororé, do Grajaú e da cidade não pretendem apenas ativar novas narrativas, mas com isso construir pontes para a legitimação e conquista de direitos básicos, como a melhoria da educação e do desenvolvimento local, com uma atuação comprometida com a autonomia dos sujeitos. Esses coletivos trabalham na construção de um novo imaginário social, pois compreendem as questões sociais estruturais que condicionam a condição precária tanto do ponto de vista espacial, quanto da estigmatizarão social dos territórios periféricos, assim, lançam uma proposta de "cura pelas bordas”. Essa frase significa que a mudança vem de "fora” - no sentido de ir da margem consciente politicamente e com importância ambiental - para “dentro” - ao irradiar para as áreas já urbanisticamente consolidadas no centro. Tal cura se inicia por meio da ressignificação das subjetividades dos próprios sujeitos periféricos e da proposição de um novo modelo de sociedade, pautado em princípios que atendam aos direitos coletivos, à dignidade humana, ao compartilhamento do bem comum, à preservação e uso 
sustentável do meio ambiente. Desse modo, a arte e a cultura estão imbuídas de uma dimensão política que atravessa as atividades desses coletivos.

[...] entender que a gente já fazendo isso, o território educativo já existe, permacultura a gente já é mestre, entender que algumas chavinhas foram tiradas, desapropriadas: comida orgânica a gente já tem, em algum momento esse processo capitalista desigual tira isso, essa ancestralidade, essa oralidade e faz com que a periferia e povos marginalizados não se vejam fazendo isso, estão distantes e a gente não tem que exportar nada porque a gente que criou essa tecnologia, a gente só tem que ressignificar e ter uma conta-narrativa de entender que a gente que criou, isso nos pertence. Falar de comida orgânica não é privilégio é direito básico, garantia de direito básico, falar de uma escola legal, disruptiva, falar de um centro de cultura legal, comunitário a gente entende como coisas básicas, né. Mas enfim é o modelo de vida que o básico é ter uma casa para morar, pagar a conta no final do mês e obviamente não tá todo mundo pronto para fazer uma discussão coletiva aberta, [...] não é todo mundo que tá preparado para essa discussão, para esse embate, né. Então isso é histórico.

(PARTICIPANTE 8, entrevista concedida a Analu Garcia, 2020).

No trecho acima, pode-se perceber que a fragmentação dos códigos comuns de culturas ancestrais, decorrente do processo de desenvolvimento capitalista globalizado, ocasionou a perda da identidade. Diante disso, as práticas de cultivo da terra e de modos de convivência coletivos, compartilhados e menos individualistas emergem em tom de reivindicação dessa cultura ancestral como uma alternativa mais humana e sustentável de se relacionar como meio ambiente.

Um conflito que foi observado por meio dos relatos e da pesquisa participante foi geracional, decorrente das propostas inovadoras da juventude organizada e da resistência de uma porção da comunidade mais antiga em aderir às ações comunitárias, por se tratarem do campo da cultura. A interpretação provém do fato de que o "produto" mais direto e imediato elaborado pelas práticas culturais não pode ser diretamente tocado, materializado, isto é, o maior ganho imediato se dá na construção de novas subjetividades, na ressignificação do imaginário social. Para moradores mais antigos que vivenciaram décadas de lentas transformações do território no que se refere à infraestrutura urbana e a presença de equipamentos púbicos, parece distante verificar qualquer potencial transformador em práticas culturais. 
Figura 51 - Folder produzido pelos “Agentes Marginais”/Imargem, 2010. Material compartilhado com a Casa Ecoativa e utilizado em suas atividades pedagógicas

\section{$6 \mathbf{A q u e l e s}$ que se dedicaram a conquistar e construjr o bairro, os pioneiros, nem sempre vêem sentido em se dedicar a coisas que imediatamente não têm utilidade, que aparentemente năo servem pra nada, como a Arte. Mas nós insistimos." Those dedicated to conquer and build the neighborhood, the pioneers, seidom think of dedicating themselves to things that have no immediate use, things that apparently do no good. such as art. But we insist." Ronaldo Silva Costa}

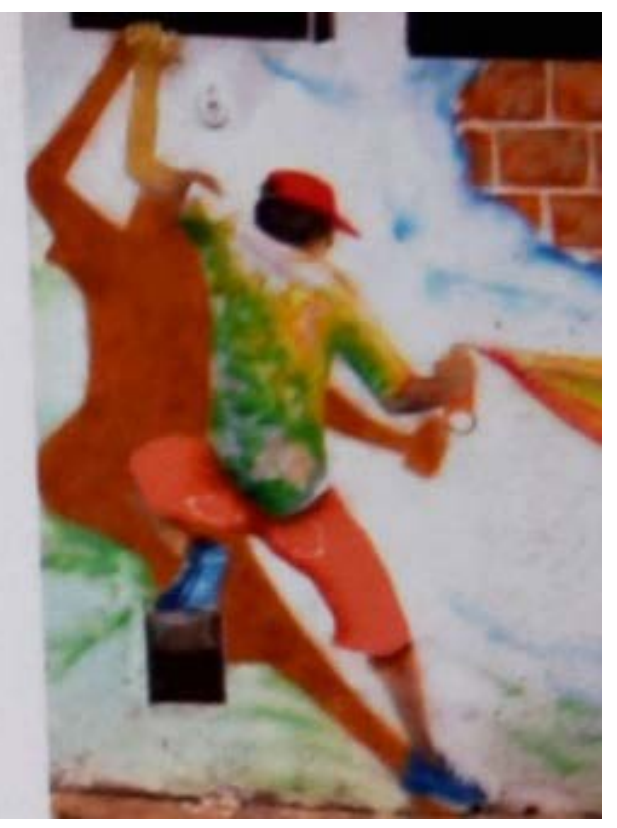

Fonte: Agentes Marginais/Imargem, 2010, foto de acervo pessoal.

Assim, a desvalorização do trabalho cultural e a "descrença” na ação socioeducativa comunitária realizada pela juventude carrega a noção de que a luta cotidiana é geracional, histórica e estrutural. Todavia, não se deve perder de vista que as famílias que ali se fixaram nas décadas anteriores viviam uma realidade muito mais isolada e rural do que a de hoje, em que a juventude dispõe de aparelhos celulares, de internet na escola e na própria Ecoativa, ampliando as possibilidades informacionais e comunicativas.

Depois de muitos anos a galera foi entender um pouco mais, depois do trabalho para escola, do trabalho com criança, entendendo inclusive que a gente tem a nossa vida pessoal [...] mas a gente tem uma barreira muito grande que é trabalho com a galera da cultura, que são assuntos que as pessoas às vezes não querem tratar como questão de gênero, como homofobia, você não pode falar, né, que o jovem pode escolher o sexo que ele quer, a orientação sexual. A gente não pode falar de intolerância religiosa, né. [...] Então a gente enfrenta todos esses essas problemáticas da sociedade, né. Então chegar dentro da escola e falar “ó você vai desenvolver um projeto da hora no seu bairro porque o seu bairro é da hora” [...] não agrada todos da comunidade porque eles querem ver o filho fazer Universidade e ir para fora - "não, ele vai morar no centro”.

(PARTICIPANTE 8, entrevista concedida a Analu Garcia, 2020). 
Essa mudança qualitativa no olhar da juventude que encabeça projetos, como os coletivos de cultura, carrega as questões de sua época - muitos nascidos a partir da década de 1990 já tiveram contato com as novas Tecnologias de Informação e Comunicação (TIC) desde cedo e, dessa forma puderam desenvolver a percepção acerca da flexibilidade, agilidade e rapidez das transformações, mesmo em contextos como os periféricos, essa juventude utiliza a tecnologia para produzir suas próprias narrativas ${ }^{69}$. De acordo com Tiarajú D’Andrea (2020), há uma “memória” relacionado às lutas de gerações passadas para conseguirem se fixar à terra, para terem condições de moradia, educação e saúde minimamente aceitáveis, como há também a forte influência do movimento cultural do hip hop e rap na década de 1990, como já mencionado no capítulo 01, com um discurso de valorização vindo “da e para a periferia”.

Para além das questões locais, relacionadas à cultura, e global, relacionada às TICs, somou-se as condições de crise do sistema capitalista a partir de 2008, as quais despertaram um olhar crítico da juventude para tal modelo e a proposição de modos alternativos de organização social pautados na solidariedade e na convivência harmônica com o meio ambiente. Nesse ponto as expressões artísticas e culturais mostram-se como alternativas para repensar as condições presentes e futuras, pois abrem espaço para resgatar as condições do passado, ativando as memórias que foram apagadas e silenciadas, bem como possibilitam processos de imaginação de futuros desejados, inventados.

[...] essa discussão entre Periferia - "é periferia, centro" - está aberta para discutir o que é borda, o que é margem de uma maneira mais poética, lúdica ou do que a gente entende, né. Óbvio que existe Periferia e a Periferia tá mais vulnerável, ninguém quer dizer ao contrário, ninguém quer dizer que a situação de vulnerabilidade não está nas periferias, mas obviamente precisa entender esse contexto porque nasce da desigualdade social, né. Nasce de um contexto histórico que essas estão mais na margem, populações LGBT, populações negras, Quilombos, é o curso do genocídio. Genocídio indígena, né, porque que tá lá no Mural-Memória do Imargem um genocídio representado da população indígena, porque esse genocídio está em curso, a gente ainda continua matando os indígenas, acabando com os quilombos. Então vem de uma história colonizadora extremamente violenta que é a história do Brasil colônia, né, que a gente vive isso muito forte, cada vez mais forte principalmente em tempos de crise, né. Aonde atinge? Quem tá morrendo? Quem que tá desamparado?

\footnotetext{
${ }^{69}$ Cf. Periferia em Movimento, "produtora de Jornalismo de Quebrada que gera e distribui informação dos extremos ao centro". Disponível em: http://periferiaemmovimento.com.br/. Acesso em 09 dez 2020. Cf. Teu Mídia: produtora audiovisual parceira da Ecoativa, com divulgação de muitos trabalhos realizados no Grajaú e região sul. Disponível em: https://www.facebook.com/Teumidia/. Acesso em 09 dez 2020.
} 
Aonde são essas casas, né? Quem que é essa população? Ela não tem CEP? Ela tem CEP. Ela não tem cor? Ela tem cor, né...

(PARTICIPANTE 8, entrevista concedida a Analu Garcia, 2020).

Apesar do importante trabalho cultura e educação desenvolvido pela juventude nos coletivos, há certa resistência de parte da sociedade com relação às linguagens utilizadas, com assuntos ainda polêmicos na sociedade brasileira, como: homofobia, gênero, classe, sexualidade etc. A escola, como instituição consolidada na sociedade, parece legitimar e configurar um território educativo comum, quando atua em parceria ou como mediadora desse diálogo entre a comunidade e os coletivos.

\subsubsection{A escola como lugar de interação sociocultural}

A Escola Estadual Professor Adrião Bernardes é a única escola do bairro do Bororé, servindo à infância, à juventude e também à comunidade como ponto de apoio e referência, por atravessar a história de diversas gerações de moradores. A escola realiza uma série de atividades inovadoras junto à comunidade local, buscando romper com o formato tradicional conteudista e experimentar processos pedagógicos em espaços não formais de aprendizagem. A realização dessas atividades passa pela iniciativa de professores comprometidos com a formação integral e cidadã dos alunos, por meio da conscientização sobre o território urbano de São Paulo e suas relações dissimétricas, bem como da conscientização sobre aspectos importantes do Bororé. Esse tipo de atividade ocorre desde 2010, por meio de visitas guiadas ao centro da cidade, assim como por meio da participação e interação em atividades com os coletivos locais em diversos lugares da ilha. Esse formato de atividades “extra-muros” ou de interação com os coletivos e comunidade “intra-muros” ficou conhecido como “Adrião Escola Aberta”.

[...] levar os alunos daqui da Ilha do Bororé para conhecer o centro da cidade, mostrar pra eles a discrepância do que é o nosso território em relação ao centro da cidade [...] saímos daqui de ônibus, fomos pro centro da cidade, nós fomos tirando fotos, mapeando o território daqui até o centro, dá mais ou menos uns 35/36 km. Do centro nós saímos a pé da Praça da República até o Mercado Municipal e nós fomos mostrando, fomos mostrando pra eles a quantidade de praças que não eram praças, construções antigas misturadas com construções novas, um emaranhado de bagunça e o contraponto da gente aqui. Nós temos uma área que é preservação ambiental - 
deveria ser -, é uma região, o único lugar de São Paulo, do Estado de São Paulo que tem balsa dentro da própria capital e que não é respeitado.

(PARTICIPANTE 3, entrevista concedida a Analu Garcia, 2019)

A “discrepância” descrita no relato tem um sentido duplo quando se trata de "presenças" e "ausências" nesses territórios. Enquanto no centro da cidade se verifica a existência de diversos equipamentos e edificações que oferecem serviços ausentes no território do Bororé, este é dotado de riqueza ambiental não percebida no centro do município e importante para toda a coletividade. A distância geográfica evidenciada pelo participante “35/36km” é fator potencializador de tais ausências e presenças. A importância desse tipo de atividade se revela na medida em que possibilita a territorialização dos alunos no centro da cidade e a interação com outros códigos não utilizados no cotidiano rural da ilha do Bororé. Tal interação, mediada pelo professor, possibilita a reelaboração simbólica por meio da internalização dessas novas informações, incidindo diretamente no desenvolvimento do aluno, como abordado por Vygotsky (2001).

Figura 52 -Escola Estadual Professor Adrião Bernardes, na Ilha do Bororé, 2019

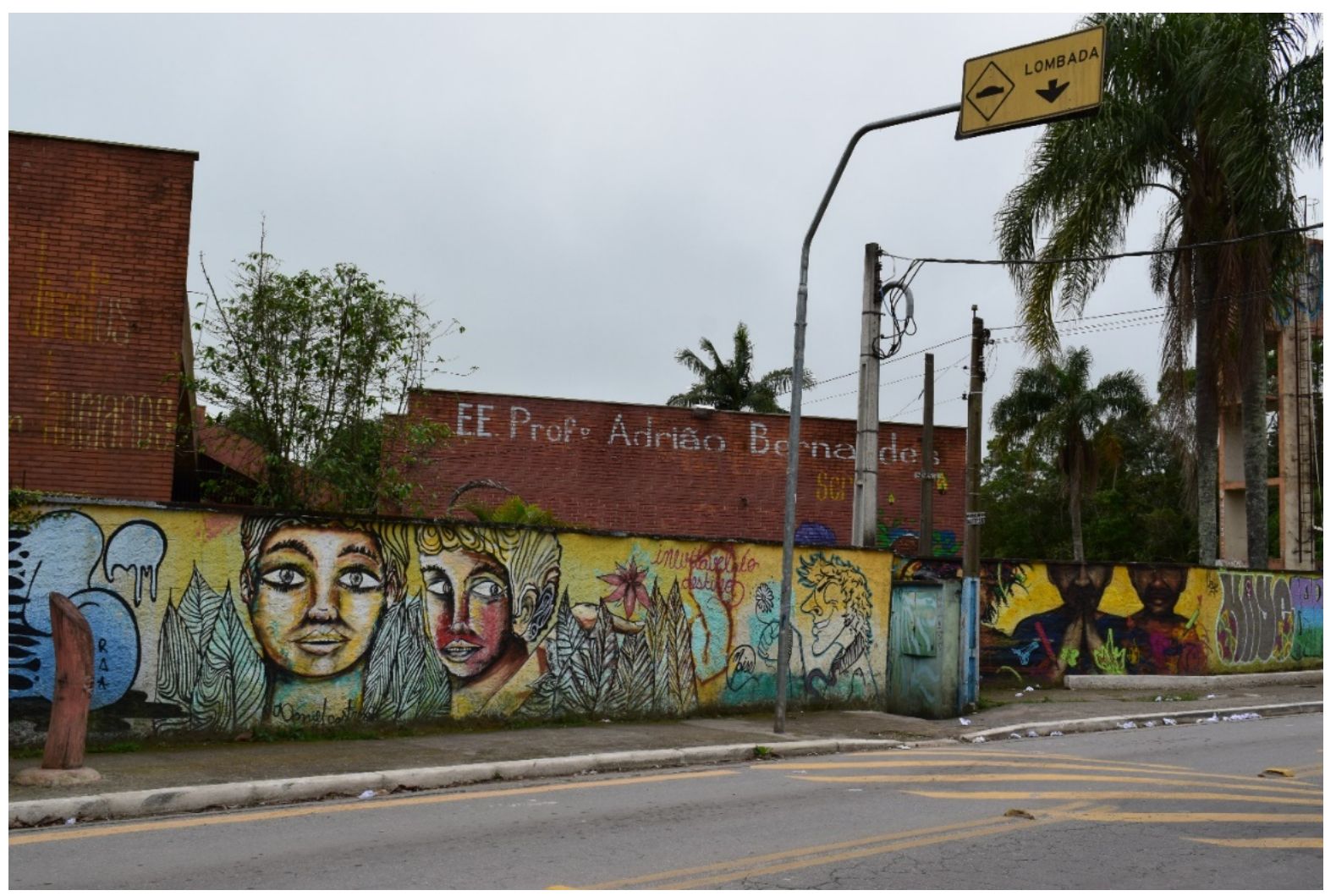

Fonte: acervo pessoal. 
Outro aspecto importante a ser destacado é a parceria da escola Adrião Bernardes com a Casa Ecoativa, desde sua constituição nos anos 1990. A partir de 2012 a escola incorpora um projeto de hortas comunitárias por meio do Programa Mais Educação, em parceria com um exaluno, atualmente um dos agentes da Ecoativa. Tais atividades iniciaram um processo de práticas educativas que estabelecem a relação de "complementaridade” entre a educação não formal e a formal, como apontado por Trilla (2008), bem como estabelece uma territorialidade “permeável” entre a escola e a comunidade.

Vale destacar que na concepção de Trilla (2008) a educação formal é aquela ligada às instituições oficiais de ensino, tais como escolas e universidades. Tal concepção não impede, todavia, que as instituições formais realizem práticas não tradicionais, notadamente em espaços não formais, como se verifica por exemplo na Adrião Escola Aberta. A educação não formal, por outro lado, como já explanado no capítulo 02, está ligada a entidades mais heterogêneas, diversas das oficiais, vinculadas à educação básica e ao ensino superior. Esse tipo de educação pôde ser verificado nas práticas da Ecoativa e Imargem.

Figura 53 - Mural feito pelo Imargem no muro da estrada velha do Bororé

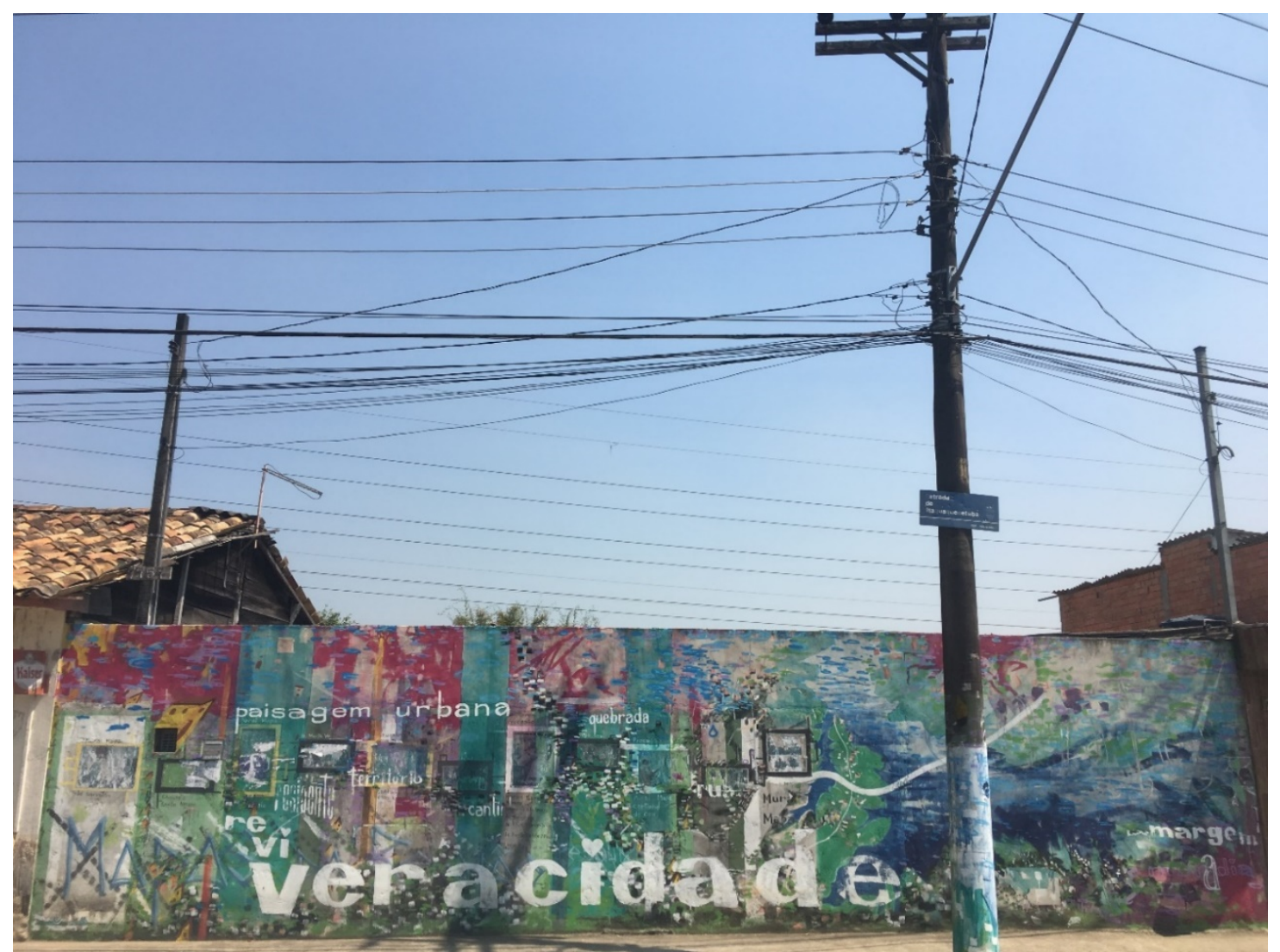

Fonte: acervo pessoal. 
Figura 54 - Graffitis ao longo dos muros no trajeto da escola até a Ecoativa

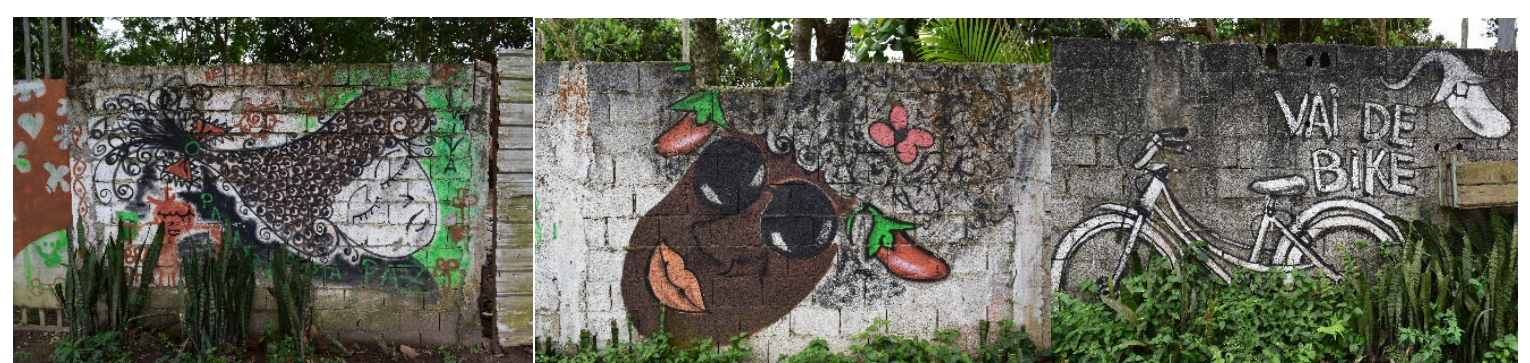

Fonte: acervo pessoal.

Em 2016 a escola Adrião Bernardes realiza sua I Mostra Cultural Adrião Escola Aberta, com oficinas, exposições, atividades culturais, lúdicas com objetivo de realizar uma interação sociocultural aberta a toda a comunidade. Nesse ano, há a parceria também de alunas e professores da Faculdade de Arquitetura e Urbanismo da Universidade de São Paulo (FAUUSP), com o desenvolvimento de oficinas de cartografia social, como parte de seus trabalhos finais de graduação sobre a região do Grajaú e a comunidade do Bororé. As parcerias com os coletivos locais e esse terceiro agente, a Universidade, a partir de 2017, desencadeou processos de experimentações metodológicas e pedagógicas, o que culminou no desenvolvimento de um projeto comum, denominado “Bororé ao Mundo”.

Figura 55 -Escola Estadual Professor Adrião Bernardes, na Ilha do Bororé, 2019

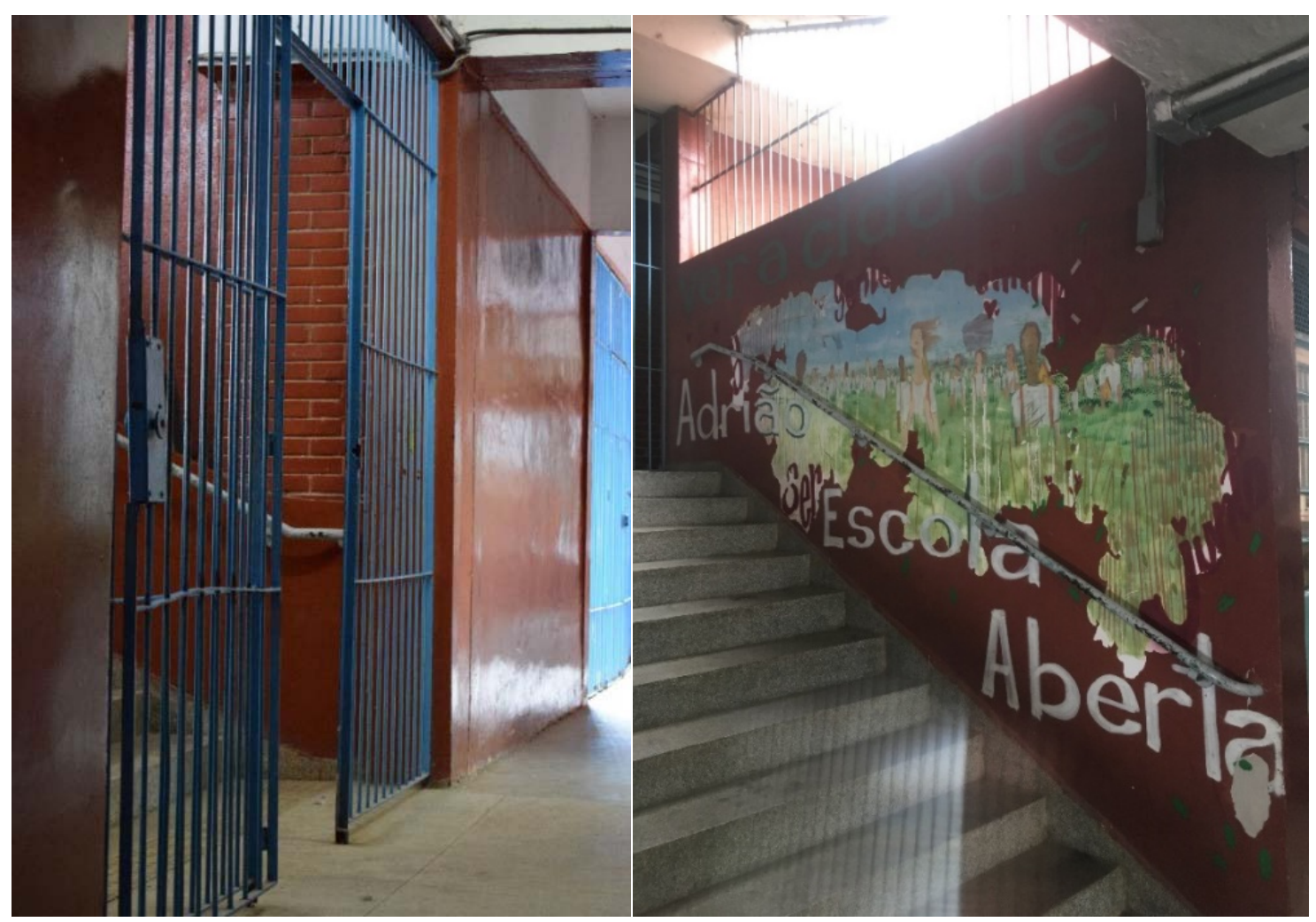

Fonte: acervo pessoal. 


\subsubsection{A extensão universitária e o projeto Bororé ao mundo}

Foi um trabalho que foi de boca em boca, levou muitos anos até eu conseguir o apoio do pessoal da USP [...]. E aí em 2017 nós começamos a colocar a mão na massa mesmo, de fato, fazendo reuniões, conversando com o pessoal da Ecoativa, conversando com alguns alunos.

(PARTICIPANTE 3, entrevista concedida a Analu Garcia, 2019).

Figura 56 -Linha do tempo com aspectos relevantes sobre o Bororé e o projeto Bororé ao Mundo

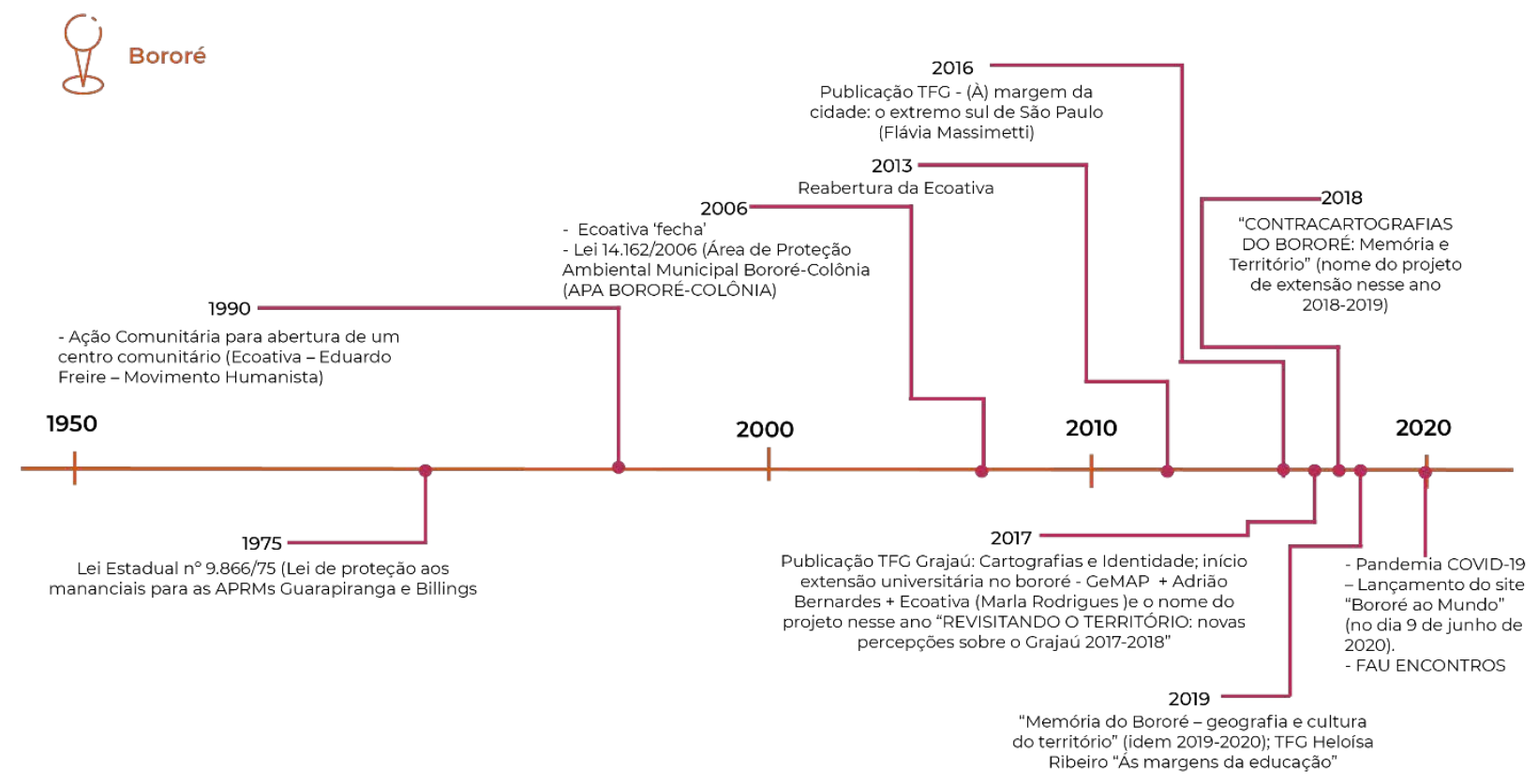

Fonte: idealização da autora, elaboração Camilla Ortega.

O projeto de extensão universitária no Bororé teve início a partir da territorialização de duas alunas da FAUUSP e de seus orientadores na ilha em 2016, possibilitando o encontro entre professores universitários e professores escolares e o compartilhamento de experiências e desejos comuns. Entre 2017 e 2018 teve início o primeiro projeto de Extensão Universitária (EU), intitulado "Revisitando o Território: novas percepções sobre o Grajaú”, coordenado pelo Grupo de Estudos de Mapografias Urbanas (GeMAP) ${ }^{70}$ da FAUUSP em parceria com a E. E. Adrião Bernardes e com a Casa Ecoativa.

O GeMAP realiza projetos de extensão com estudantes de segundo grau de escola pública desde 2012, utilizando a linguagem cartográfica de maneira central na discussão do

${ }^{70}$ Cf. Grupo de Estudos de Mapografias Urbanas. Disponível em: https://gemapfau.wixsite.com/fauusp. Acesso em 12 dez 2020. 
território em todas as suas camadas. Desse modo, a proposta de trabalho do projeto de EU no primeiro ano do projeto consistiu em compreender as percepções e as representações do território, por meio de atividades relacionadas à cartografia e ao cotidiano.

[...] nós fizemos o primeiro trabalho, que era mais ou menos isso, né, com os alunos: nós pegamos um mapa da Ilha do Bororé, né, da região, uma parte da Ilha do Bororé e começamos a mapear. [...] A nossa primeira intenção era marcar onde os alunos moravam dentro da Ilha do Bororé - no projeto e fora do projeto.

(PARTICIPANTE 3, entrevista concedida a Analu Garcia, 2019).

Figura 57 - Atividade de mapeamento realizada pelos alunos da EU, na escola Adrião Bernardes

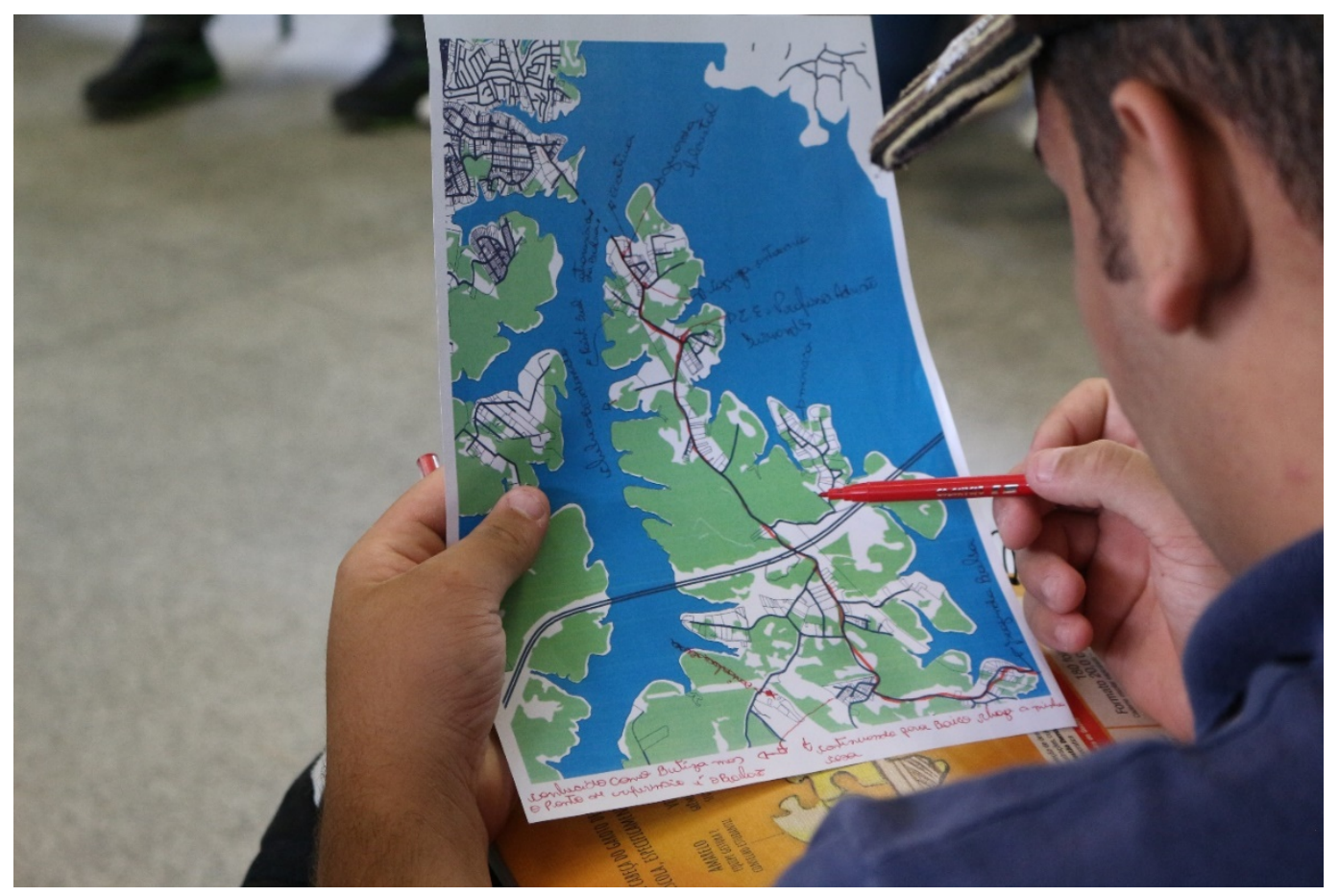

Fonte: acervo GeMAP/USP.

Figura 58 - Oficinas de cartografia na E. E. Adrião Bernardes com os alunos do projeto de extensão universitária

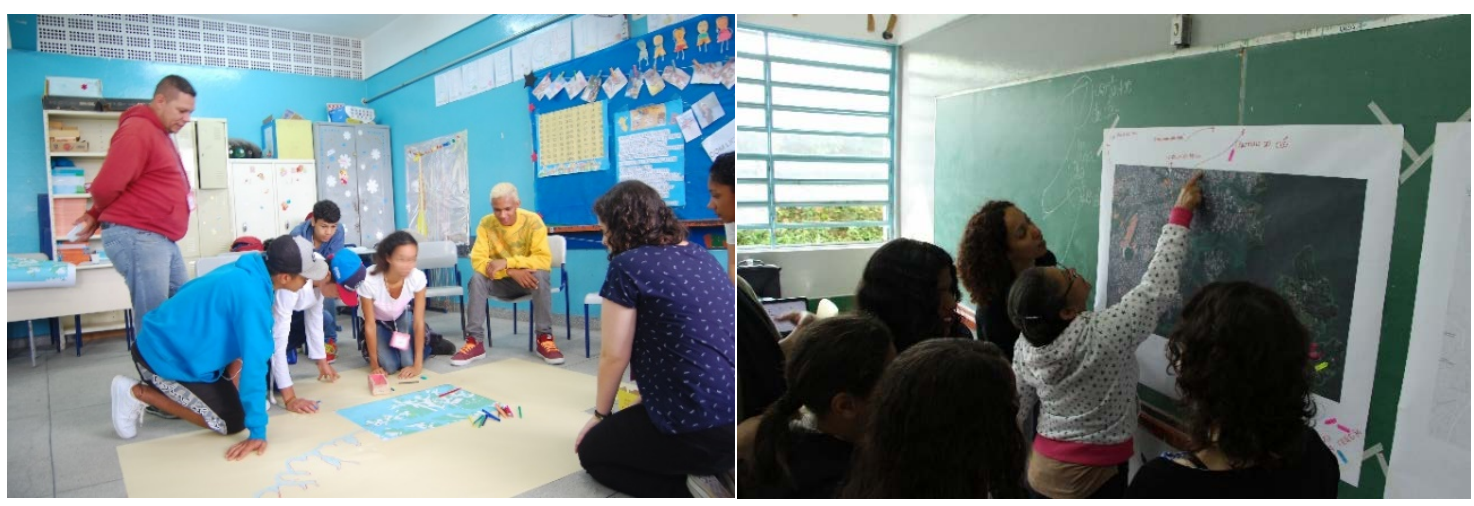

Fonte: acervo GeMAP/USP. 
Figura 59 - Atividade de mapeamento realizada pelos alunos da EU, na escola Adrião Bernardes.

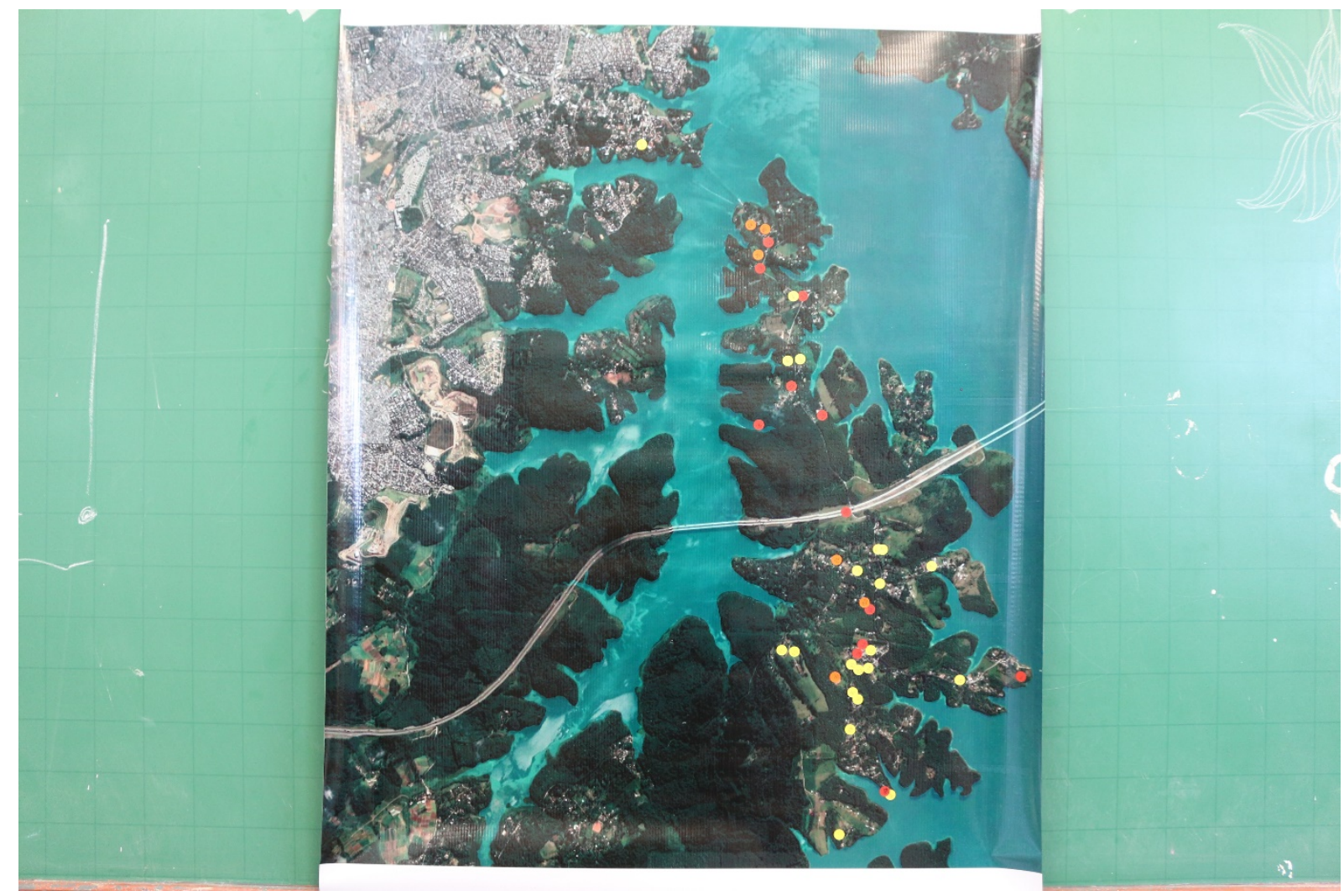

Fonte: acervo GeMAP/USP.

Entre 2018 e 2019, o grupo dá continuidade às atividades em parceria e o projeto passa a se chamar "Contracartografias do Bororé: Memória e Território”, com a continuidade de oficinas que apresentavam a cartografia como instrumento apto a auxiliar nas transformações do território, e não apenas como estímulo ao reconhecimento. Nesse momento as práticas também foram ampliadas para a comunidade e coletivos locais, incorporando a dimensão participativa e formativa comunitária. No mesmo ano surgiu a ideia da realização de um Memorial para o bairro do Bororé, com objetivo de formar jovens pesquisadores da ilha que pudessem atuar de forma territorializada no âmbito educacional e comunitário.

[...] e aí nós sentimos a necessidade de conhecer mais a nossa região, porque a gente só tinha marcas de ruas conhecidas e nós percebemos que tinha mais ruas aí que não estavam dentro do sistema real, né, eram ruas clandestinas, habitações clandestinas, mas se você passar, você pode passar assim em frente dessas ruas e você só via trilha, mata do lado, mas no fundo, casa. Então minha preocupação de ocupação desordenada. Então qual foi a ideia: a realização do território e ao mesmo tempo mantendo a condição de que quem mora na Ilha pudesse trabalhar aqui na própria 
Ilha, não precisar atravessar a represa pra ir trabalhar do outro lado, ou seja, gerar emprego dentro do próprio território sem que as pessoas saíssem. E aí começou o nosso trabalho.

(PARTICIPANTE 3, entrevista concedida a Analu Garcia, 2019).

Figura 60 - Oficina de mapeamento com a ONG Teto, 2019

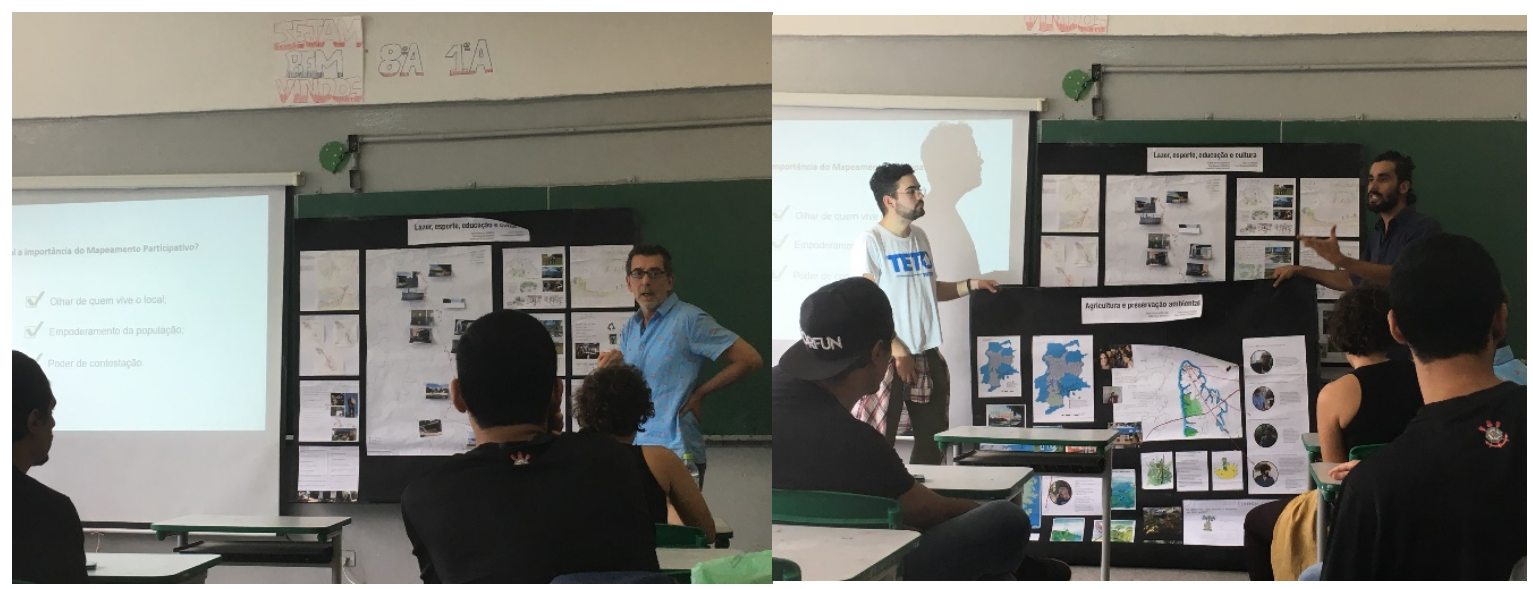

Fonte: acervo pessoal.

É importante destacar a linguagem cartográfica como central nos trabalhos desenvolvidos com a extensão universitária, tanto como instrumento de pesquisa e ensino, como de representação do território. A elaboração de dois mapas da ilha do Bororé em grande escala, um no pátio da escola e outro no muro em frente ao cruzeiro, objetivaram apresentar uma nova percepção e representação do território pelas crianças e jovens envolvidos nessas atividades.

Figura 61 - Atividade com os alunos do Adrião Bernardes, elaboração do molde do mapa em grande escala

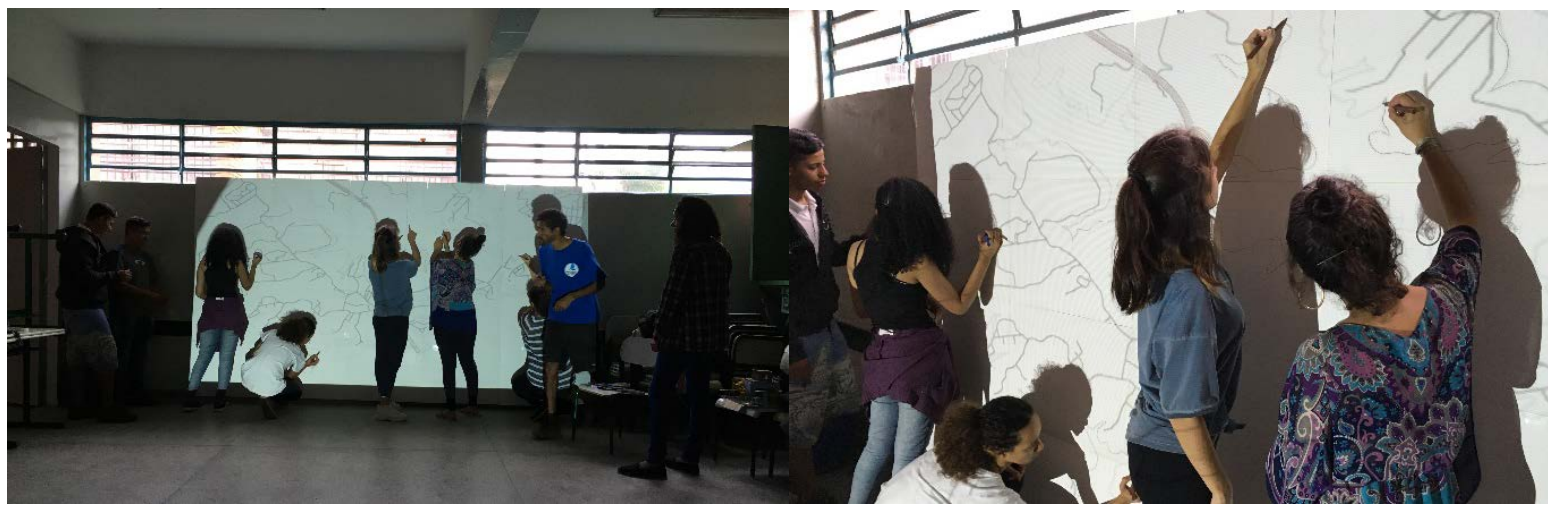

Fonte: acervo GeMAP/USP. 
Figura 62 - Atividade com os alunos do Adrião Bernardes, pintura do mapa do Bororé no pátio da escola

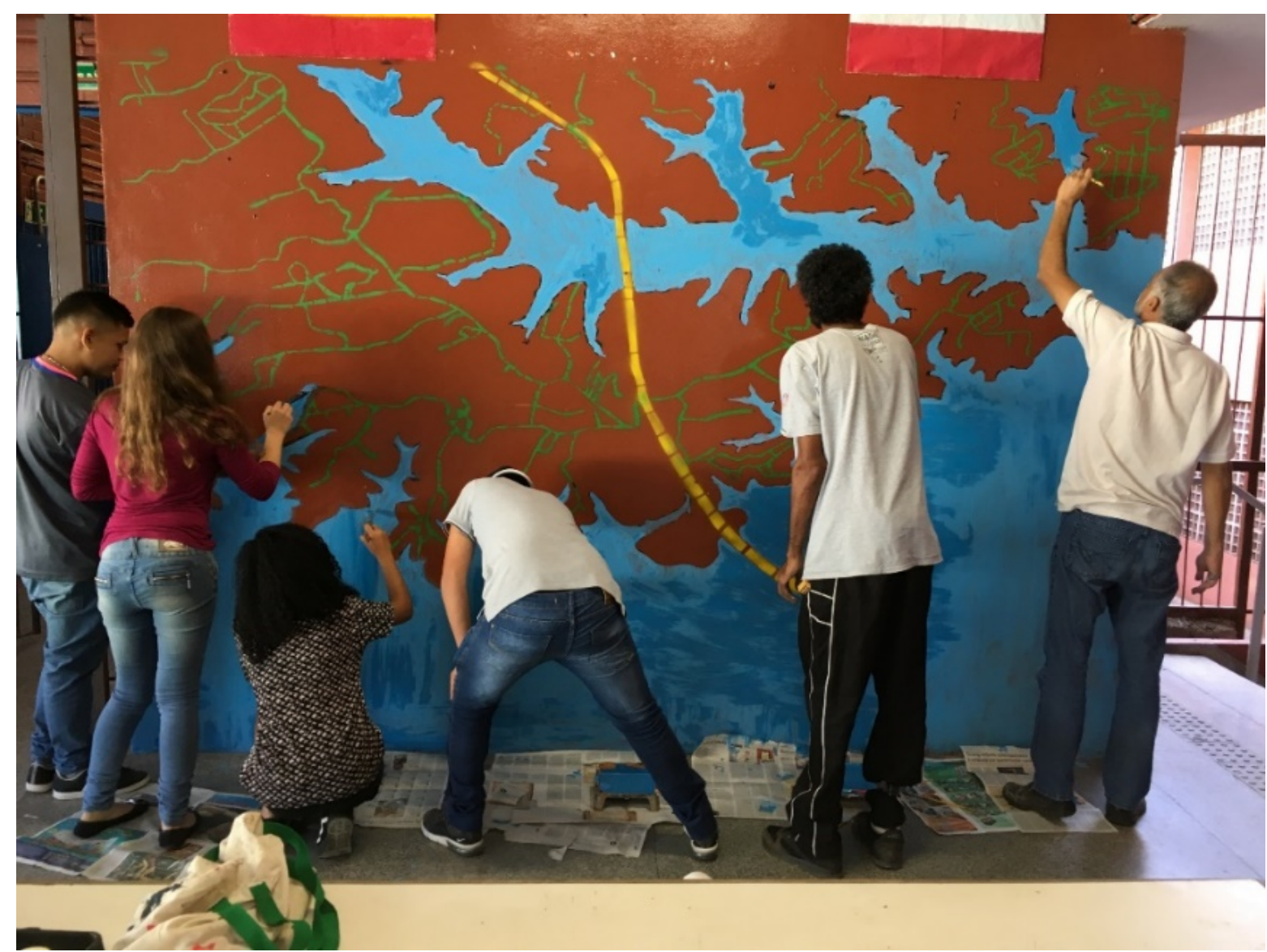

Fonte: acervo GeMAP/USP.

Figura 63 - Participantes do projeto de extensão no trajeto da escola até a Ecoativa

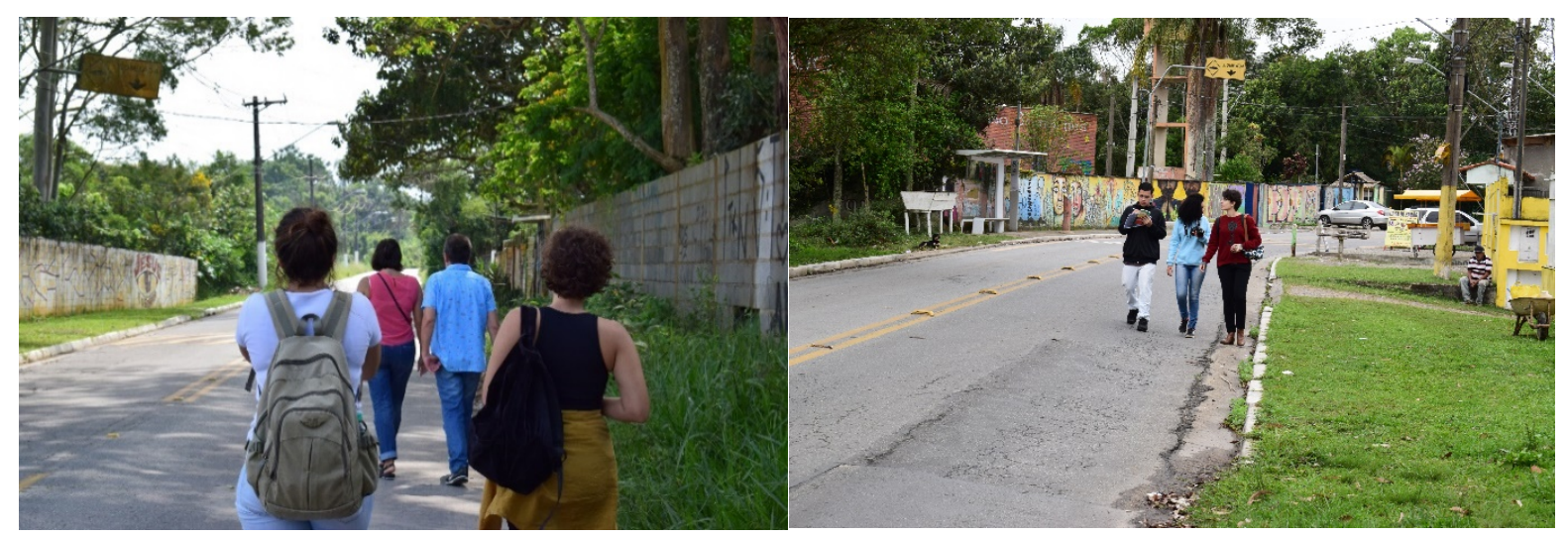

Fonte: acervo pessoal.

Integraram as atividades, também, caminhadas guiadas pelo bairro, bem como no trajeto entre a escola e a casa Ecoativa, marca territorial estabelecida por essa parceria escolacoletivo-extensão na construção de um território educativo. As caminhadas guiadas entre os dois pontos do território configuram uma experiência educativa, tendo a paisagem como 
instrumento de leitura dos processos territoriais e para o mapeamento de pontos específicos. Essa atividade estimula o desenvolvimento da compreensão espacial, ao explorar aspectos da dimensão do concreto para a formação de uma representação mais abstrata. Aqui, a prática pode ser analisada sob a ótica de Vygotsky (2001).

O espaço que a criança está acostumada a perceber com os sentidos, muitas vezes é diferente de outros espaços do município frequentemente retratados nas diversas mídias, como televisão e internet. Desse modo, a cartografia estampada nos muros da escola ajuda na formação de uma representação mental das crianças sobre o lugar, ampliando os horizontes para abarcar os novos limites apresentados de forma gráfica. Assim, a criança que frequentemente costuma ter em mente a representação de um território limitado ao trajeto entre casa e escola, por exemplo, passa a ter uma melhor percepção sobre o local que está inserida, tomando consciência da dimensão de outros elementos pertencentes ao território como as águas, a vegetação, para além dos objetos e espaços percebidos no cotidiano. Das atividades realizadas e perfil dos participantes, notadamente crianças, pôde-se perceber que a linguagem cartográfica nas práticas do Bororé apresenta cunho mais relacionado ao desenvolvimento cognitivo e do desenvolvimento do pensamento espacial.

Figura 64 - Atividade preparatória de reconhecimento do território e dos lugares de importância para a comunidade com as crianças da ilha no programa Ecoativa Férias, 2019

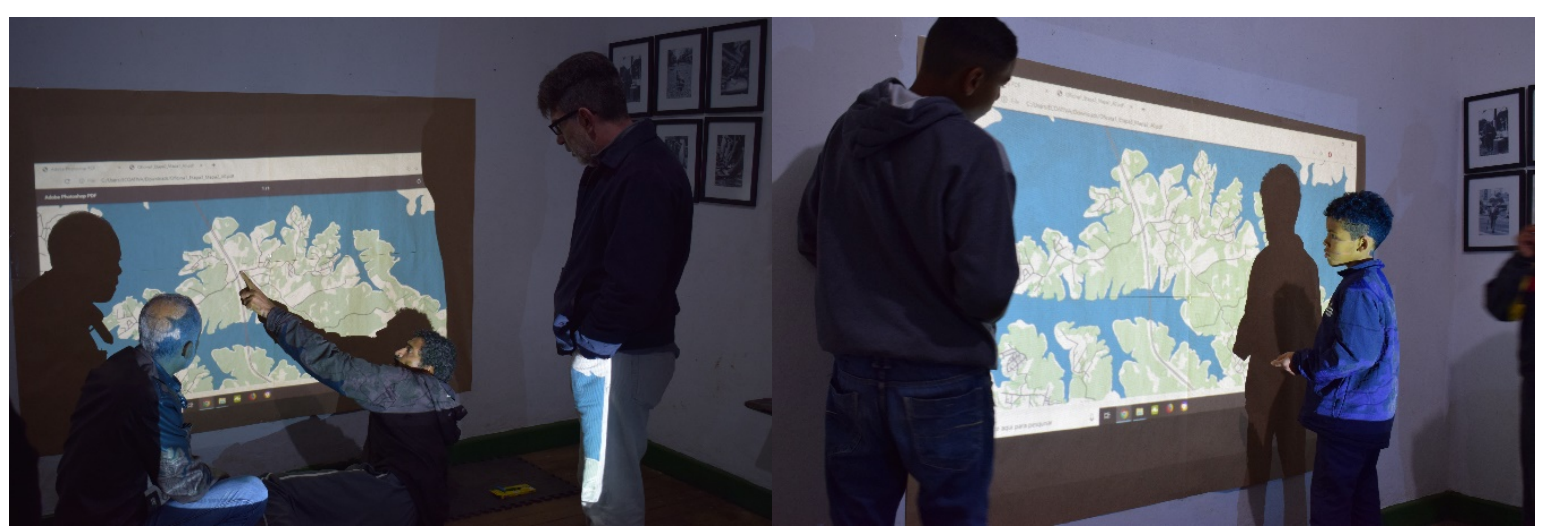

Fonte: acervo pessoal. 
Figura 65 - Atividade da Ecoativa Férias, 2019

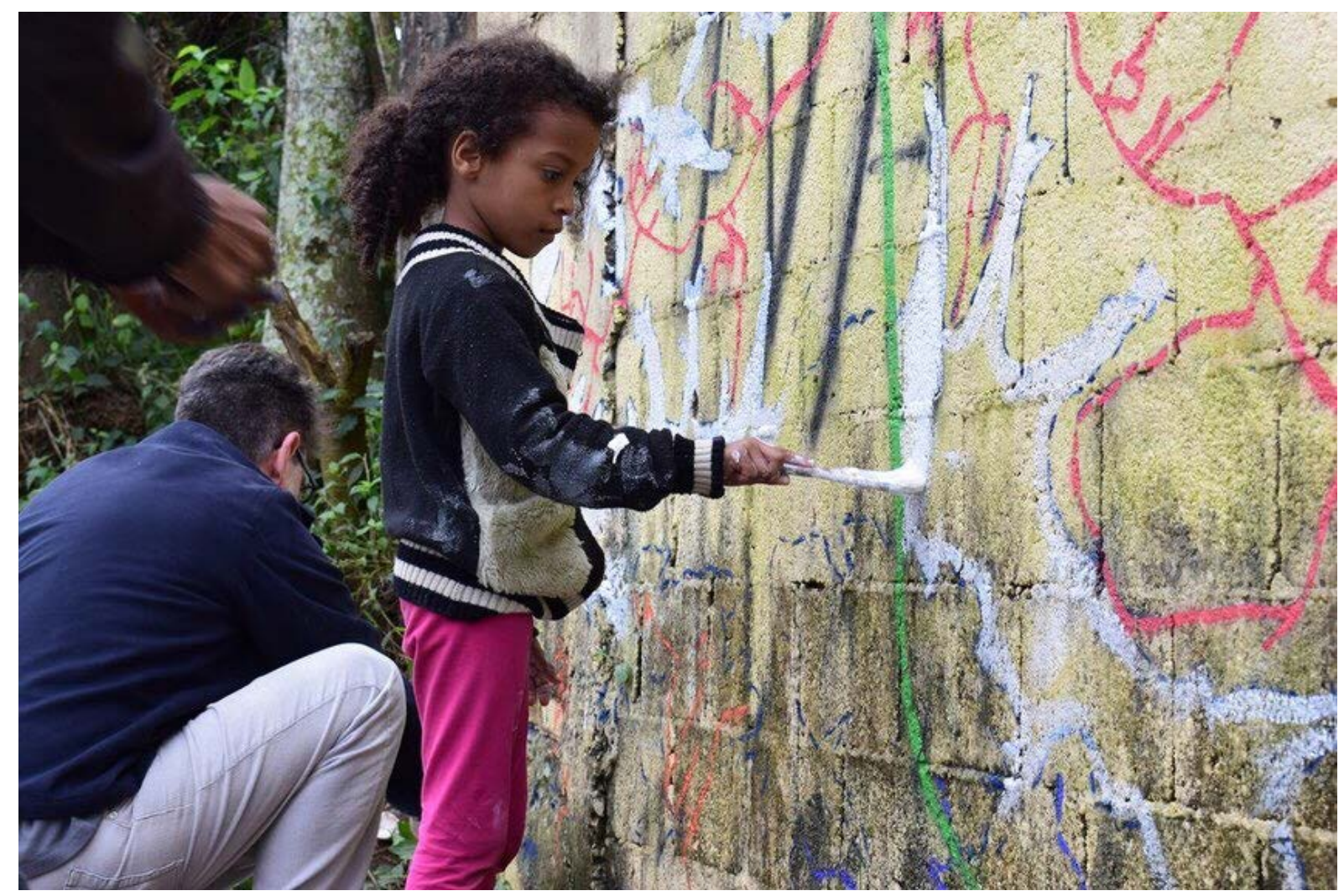

Fonte: acervo pessoal.

Em 2019, o projeto de extensão passa a ser denominado “Memória do Bororé-Geografia e Cultura do Território”, com o objetivo de elaborar um memorial para a ilha.

Então é por isso que eu falei que o projeto, ele é a longo prazo. Tem que fazer os dois, tanto o mapeamento territorial, por foto, por entrevista, né, quanto pra chegar e depois montar essa maquete. No final a gente vai fazer “a” maquete da Ilha do Bororé, a ideia final é essa, né, e montar o nosso memorial, né, aberto que seria toda essa história da ilha já na própria região e também um centro de pesquisa, vamos dizer assim, né [...] um centro de pesquisa da ilha do Bororé aonde vai ter umas fotos, vai ter essa maquete, vai ter alguns relatos, né, já dentro de um computador para as pessoas ir lá pesquisar como se fosse um minimuseu.

(PARTICIPANTE 3, entrevista concedida a Analu Garcia, 2019).

Uma das primeiras estratégias para resgatar a dimensão da memória foi a realização de entrevistas com moradores antigos pelos jovens estudantes participantes do projeto, a fim de possibilitar a troca de conhecimentos entre gerações. As entrevistas buscaram registrar relatos a respeito do modo de vida e relações no território em décadas passadas. Também no ano de 
2019, o Projeto Bororé ao Mundo teve participação na Mostra Cultural realizada pela escola Adrião Bernardes, na qual se realizou exposição de fotografias, vídeos, e mapas do trabalho desenvolvido.

Figura 66 -Entrevista com Dona Sueli, moradora antiga do Bororé, realizada pelos alunos do Adrião Bernardes com o apoio do grupo de extensão universitária e da Casa Ecoativa, 2019

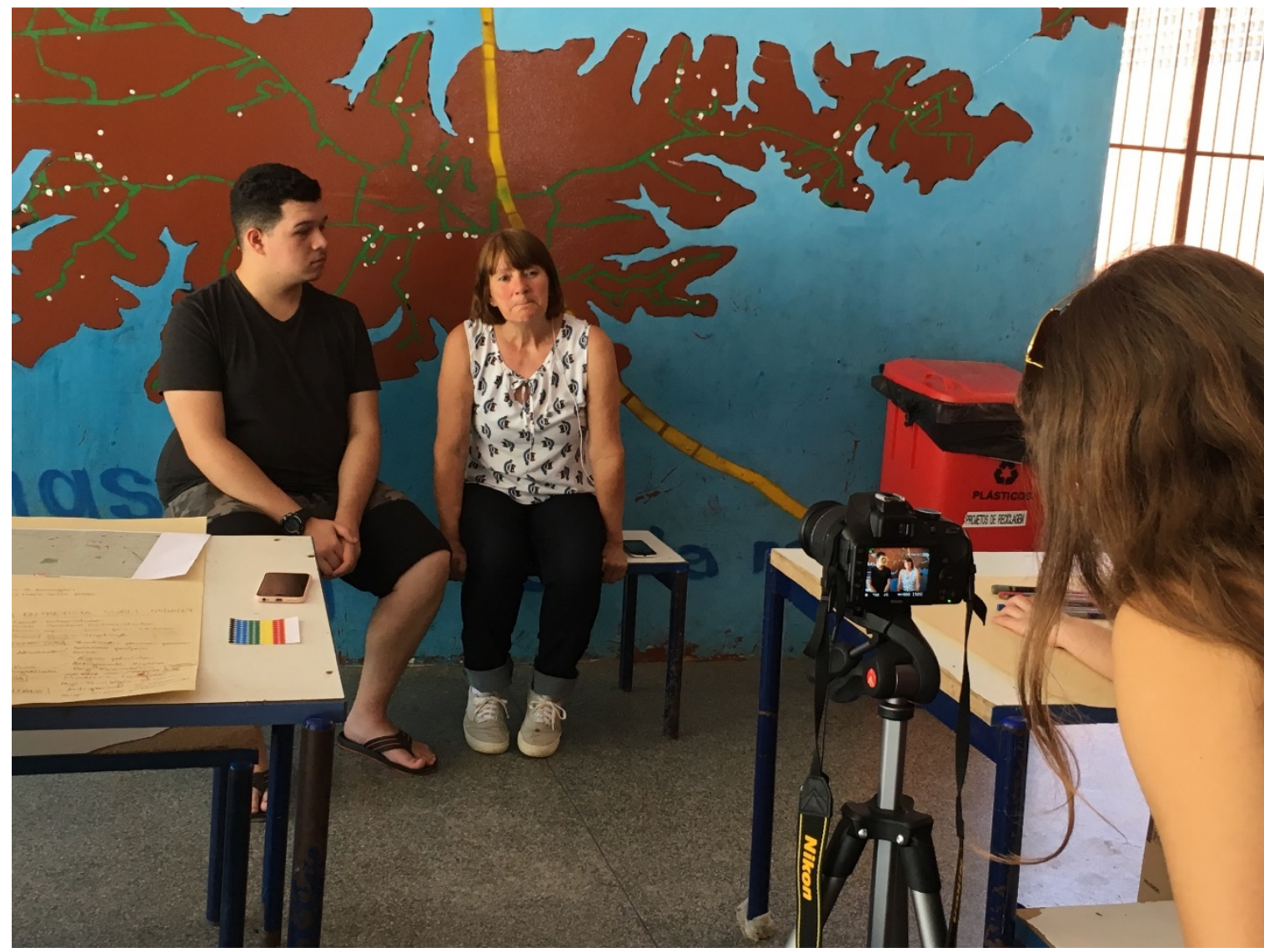

Fonte: GeMAP/USP. 
Figura 67 - Entrevista com a Dona Eva e o Sr. Nelson, moradores antigos do Bororé, 2019

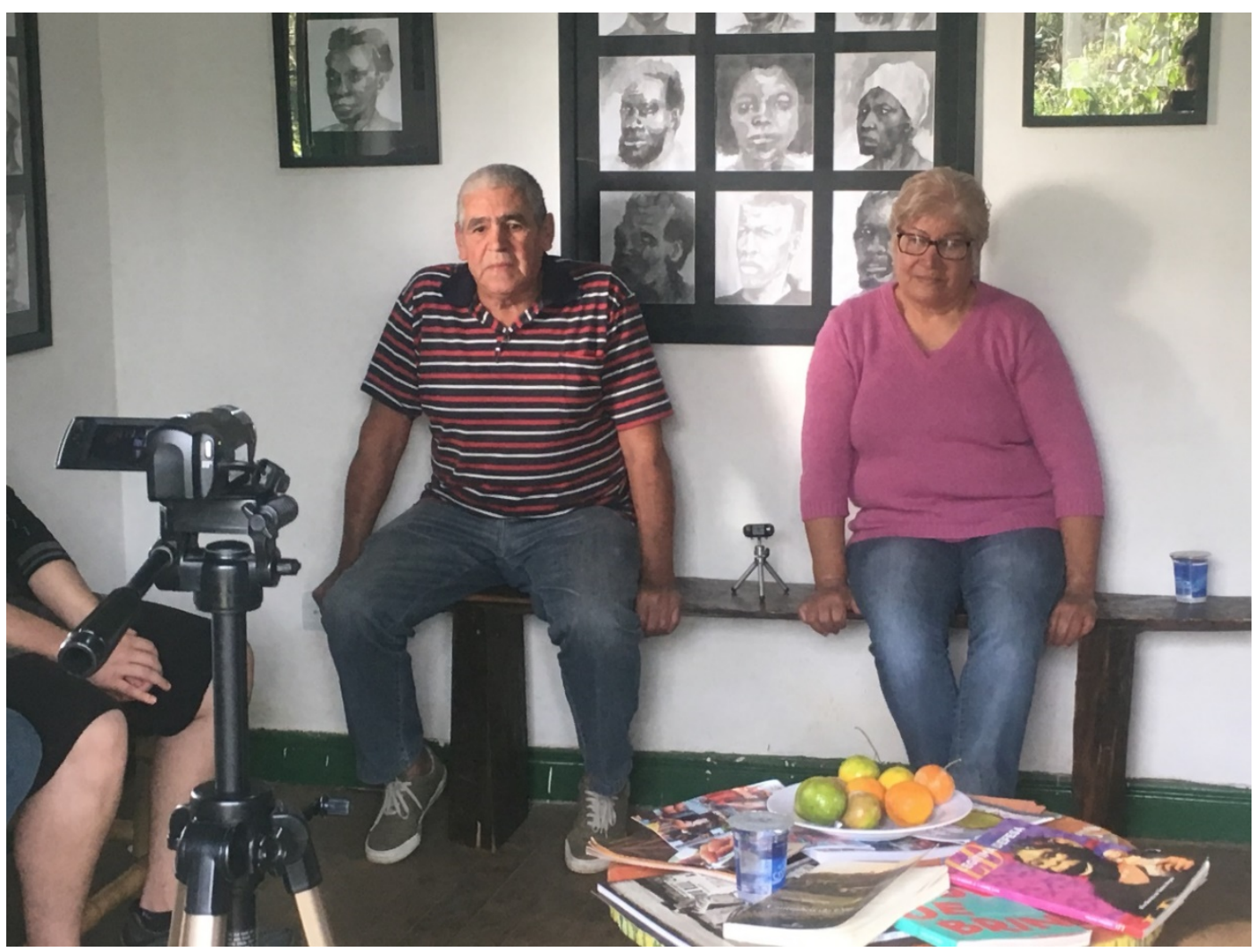

Fonte: acervo pessoal.

Figura 68 - Mostra Cultural da Escola Adrião Bernardes, 2019

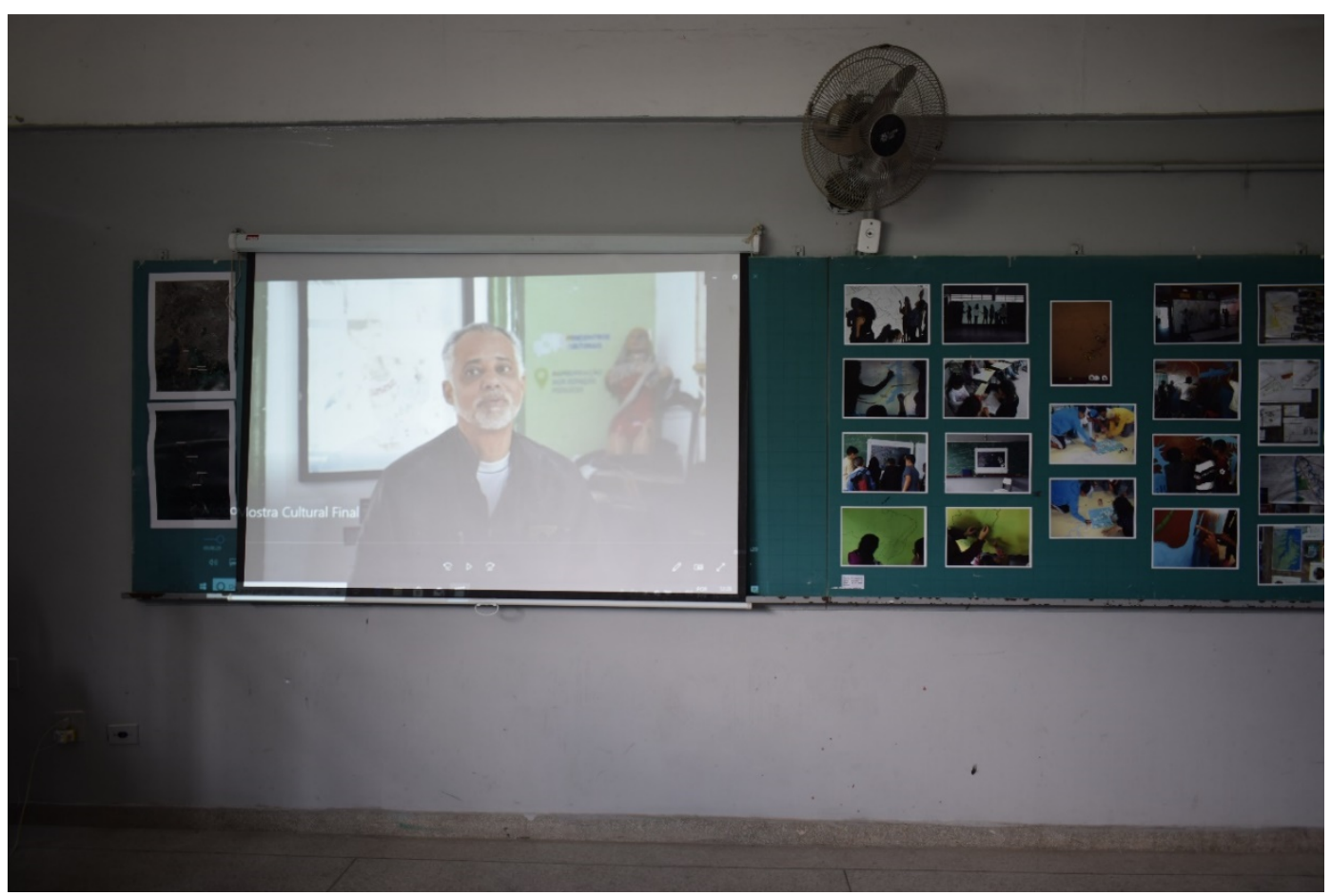

Fonte: acervo pessoal. 
Vale registrar que o projeto Bororé ao Mundo é formado pela Universidade de São Paulo, através da extensão, pela escola Adrião Bernardes e pela casa Ecoativa. Assim, embora o projeto tenha participação de instituições ligadas à educação formal (universidade e escola), conta também com um coletivo de cultura que desenvolve atividades dentro do que se convencionou chamar de educação não-formal.

Outro eixo de ação foi a sistematização dos dados obtidos ao longo dos três últimos anos em uma plataforma digital que pudesse ser alimentada por todos de forma contínua no curso do desenvolvimento do projeto, bem como servisse de instrumento de divulgação científica das atividades realizadas na comunidade. Desse modo, foi lançado um site em junho de 2020 em um evento de quatro encontros organizado pelo grupo e transmitido pelos canais de comunicação da Casa Ecoativa. Ainda em 2020, o Projeto Bororé ao Mundo foi um dos vencedores do "Edital para "Formação EAD em Tecnologia Social da Memória para a criação de núcleos do museu da pessoa em museus do Estado de São Paulo.

Figura 69 - Site Bororé ao Mundo, 2019

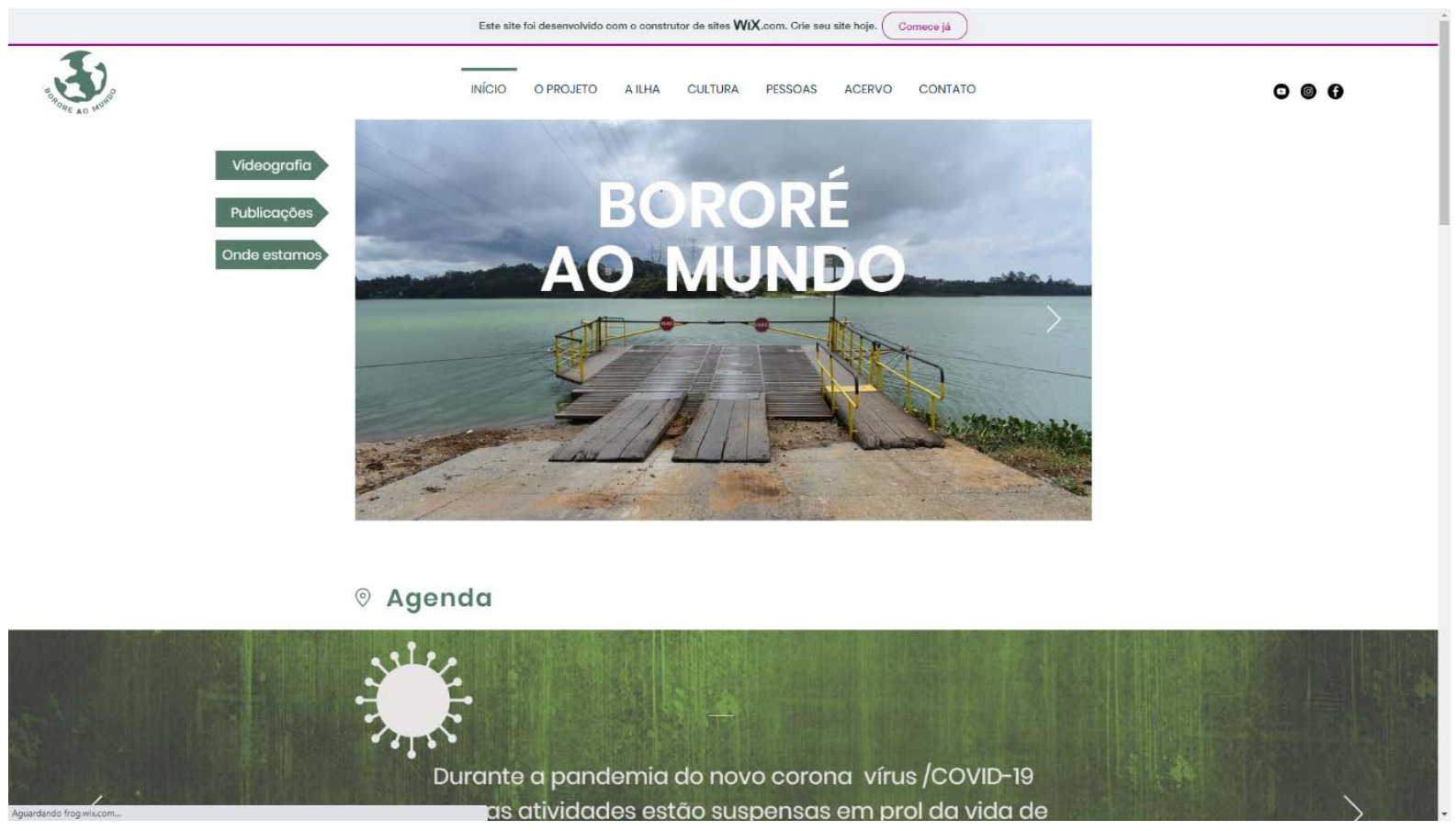

Fonte: < https://bororeaomundo.wixsite.com/memorial>. Acesso em $10 \mathrm{dez} 2020$. 
Figura 70 - Marcação dos locais encontrados durante a entrevista da Dona Sueli, em atividade do projeto de extensão universitária "Bororé ao Mundo"

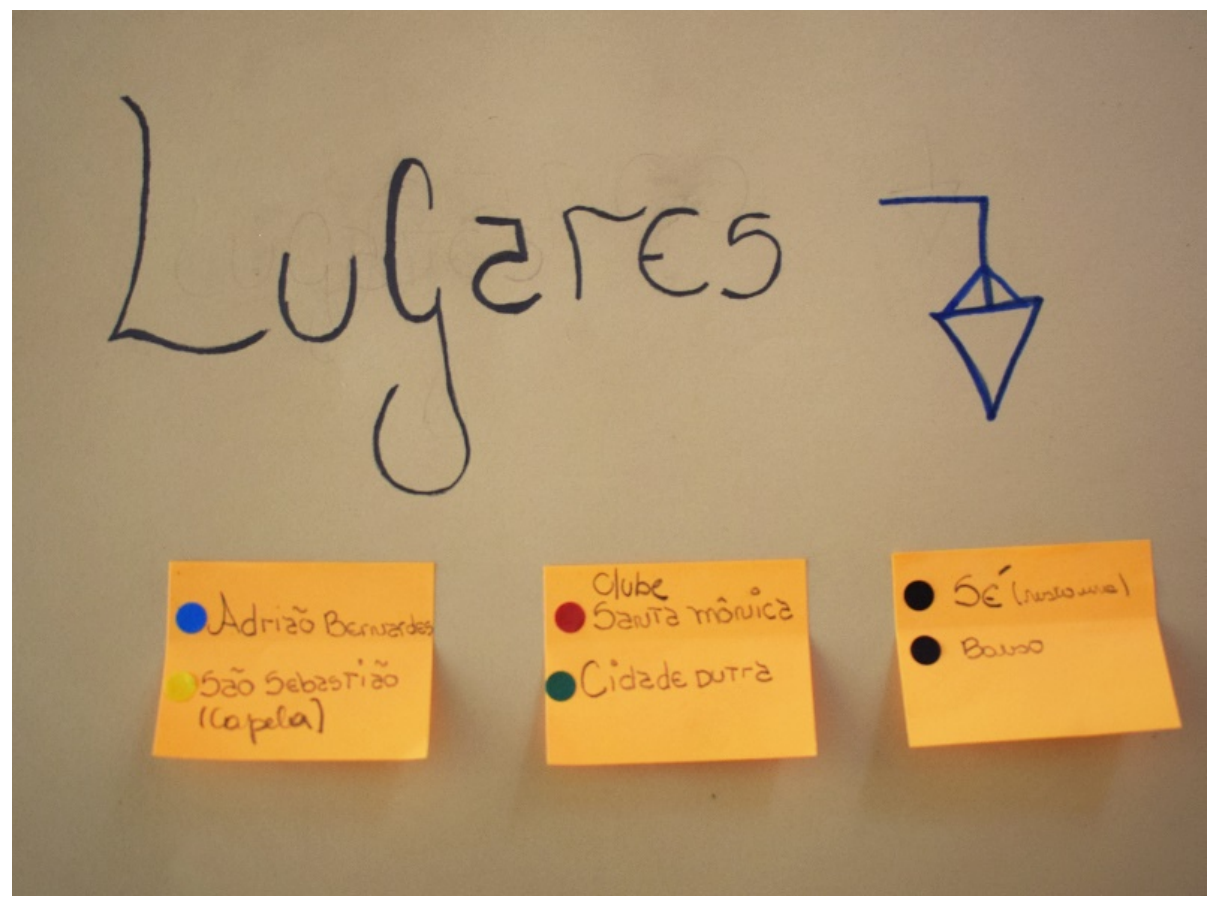

Fonte: acervo pessoal.

Figura 71 - Dados coletados durante a entrevista da moradora e cuidadora da Capela de São Sebastião, dona Sueli, em atividade do projeto de extensão universitária “Bororé ao Mundo”.

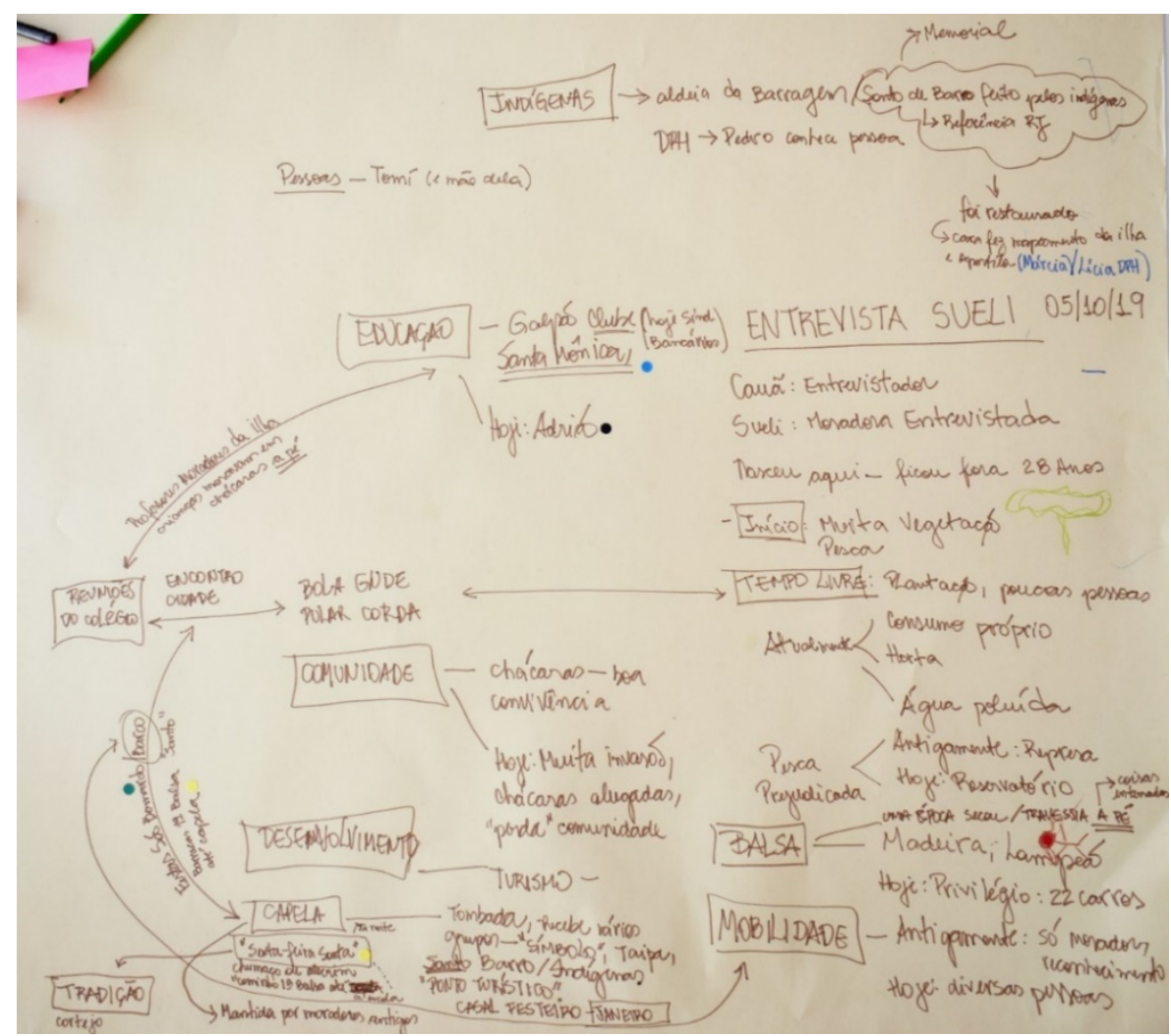

Fonte: acervo pessoal. 
Figura 72 - Ilustração com a representação dos agentes com quem tive maior contato no âmbito da Extensão Universitária na Ilha do Bororé, 2019

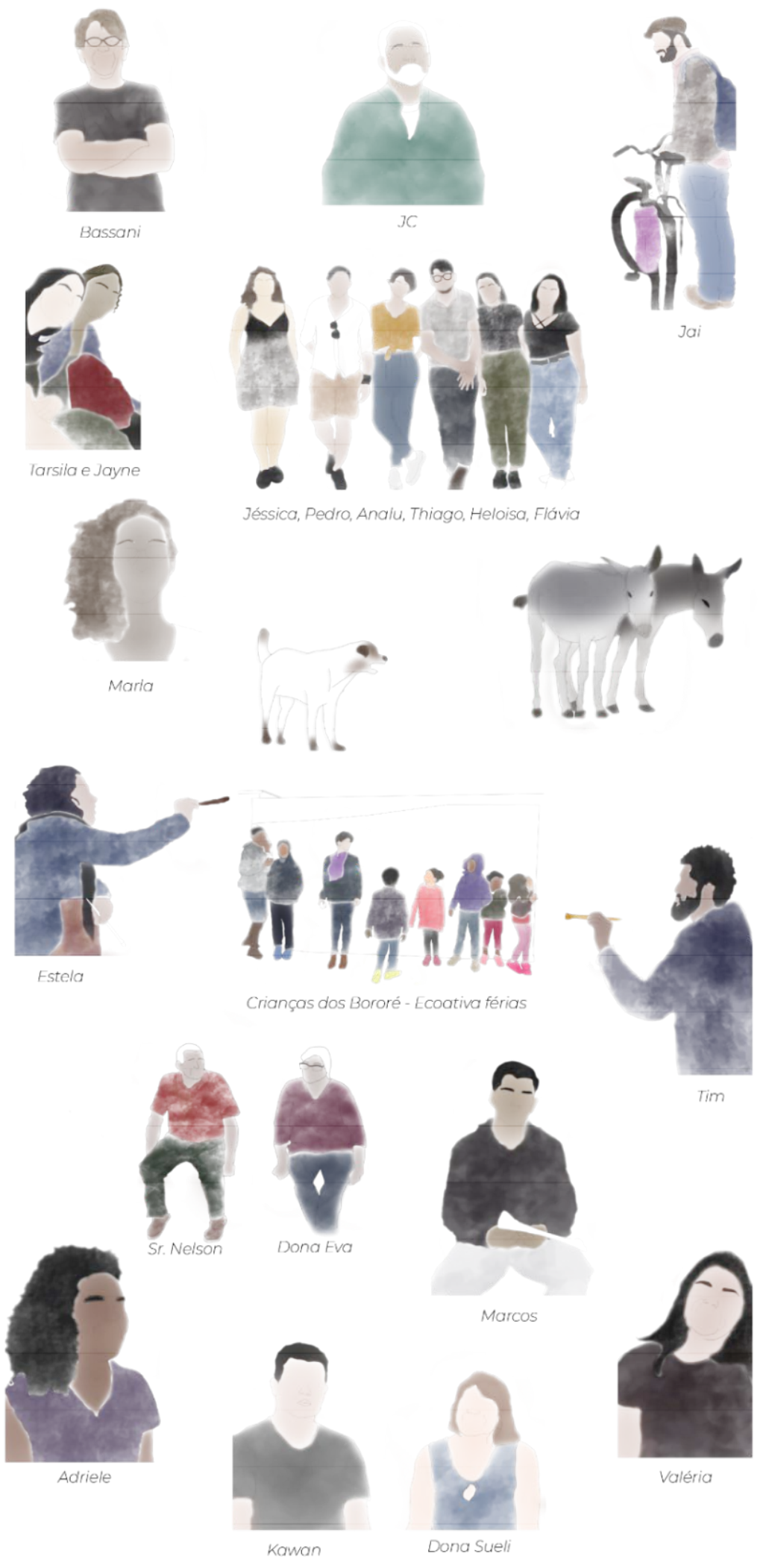

Fonte: idealização da autora, elaboração Camilla Ortega. 
Figura 73 - Nuvem de palavras a partir dos relatos dos participantes do Bororé

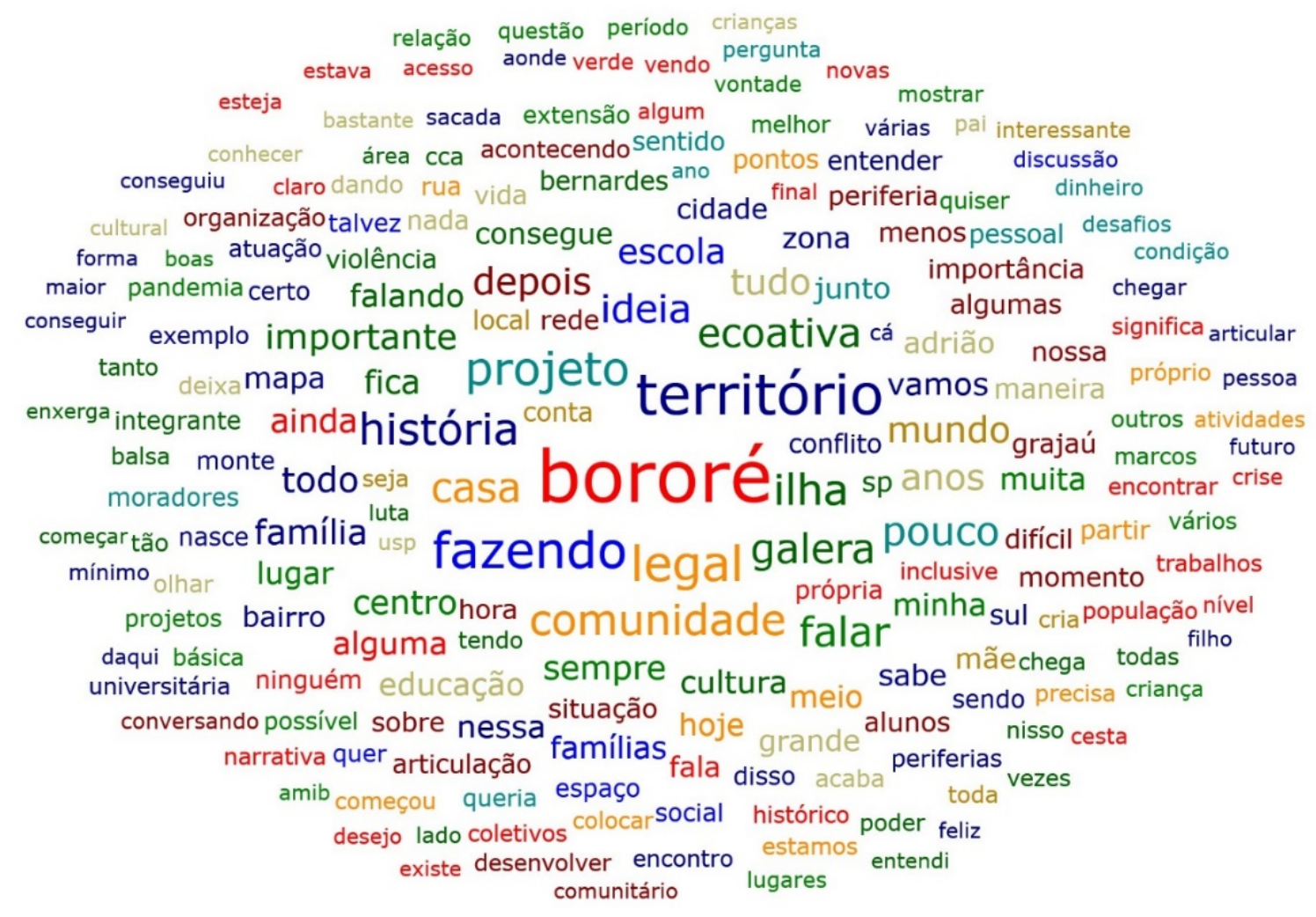

Fonte: elaboração da autora, por meio do software ATLAS.ti 9.

\subsubsection{As práticas educativas no Bororé na ótica da educação freireana}

Como visto, as principais atividades educativas identificadas no território do Bororé se relacionam ao trabalho feito pelos coletivos de cultura, pela escola Adrião Bernardes e pelos trabalhos de extensão universitária. Nessas atividades tanto por meio da percepção in loco, como por meio dos registros feitos com base nas entrevistas realizadas com os agentes locais, foi possível identificar aspectos da concepção freireana de educação, o que se demonstra através de elementos elencados por Gadotti (2012, p. 23) como representativos das “contribuições de Paulo Freire à educação popular, social e comunitária”:

“1. Teorizar a prática para transformá-la. A prática como base para gerar pensamento. Os sujeitos populares como protagonistas do seu próprio aprendizado e atores de sua emancipação” (GADOTTI, 2012, p. 23): 
Figura 74 - Trecho do Mapa de Intervenções do projeto Imargem, com destaque para o Mural Memória e a linguagem artística do graffiti

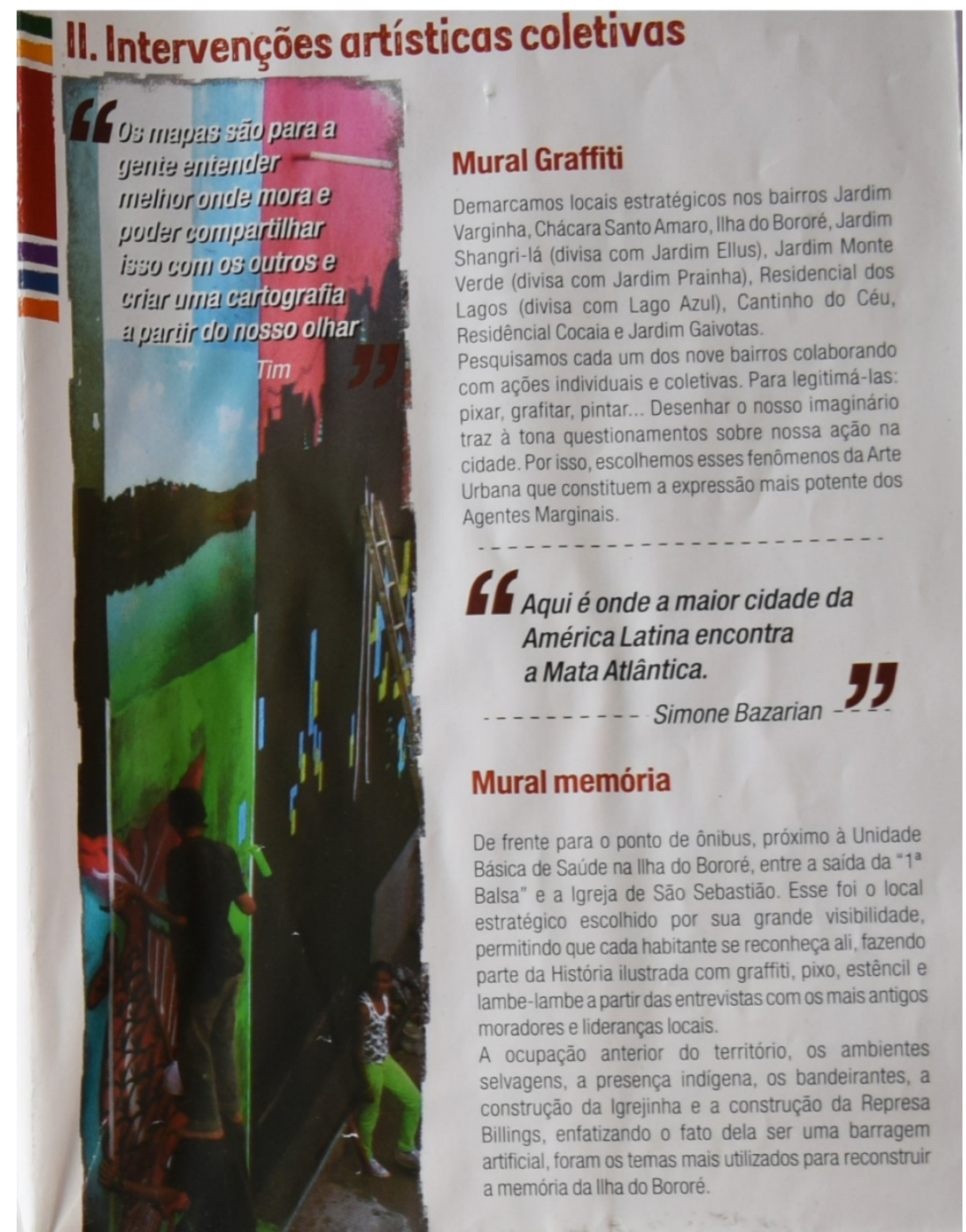

Fonte: Projeto Imargem, foto de acervo pessoal.

Nesse sentido, aponto o trabalho do coletivo Imargem, responsável pela elaboração do Mural-Memória da Ilha do Bororé. O trecho destacado na imagem acima representa a construção de conhecimento histórico por meio da associação da pesquisa diretamente com o conhecimento das experiências locais, tendo os coletivos territorializados (BASSANI, 2019) como protagonistas do processo. 
Figura 75 - Trecho do Mapa de Intervenções do projeto Imargem, com destaque para a sensibilização ambiental por meio das trilhas verdes na região sul

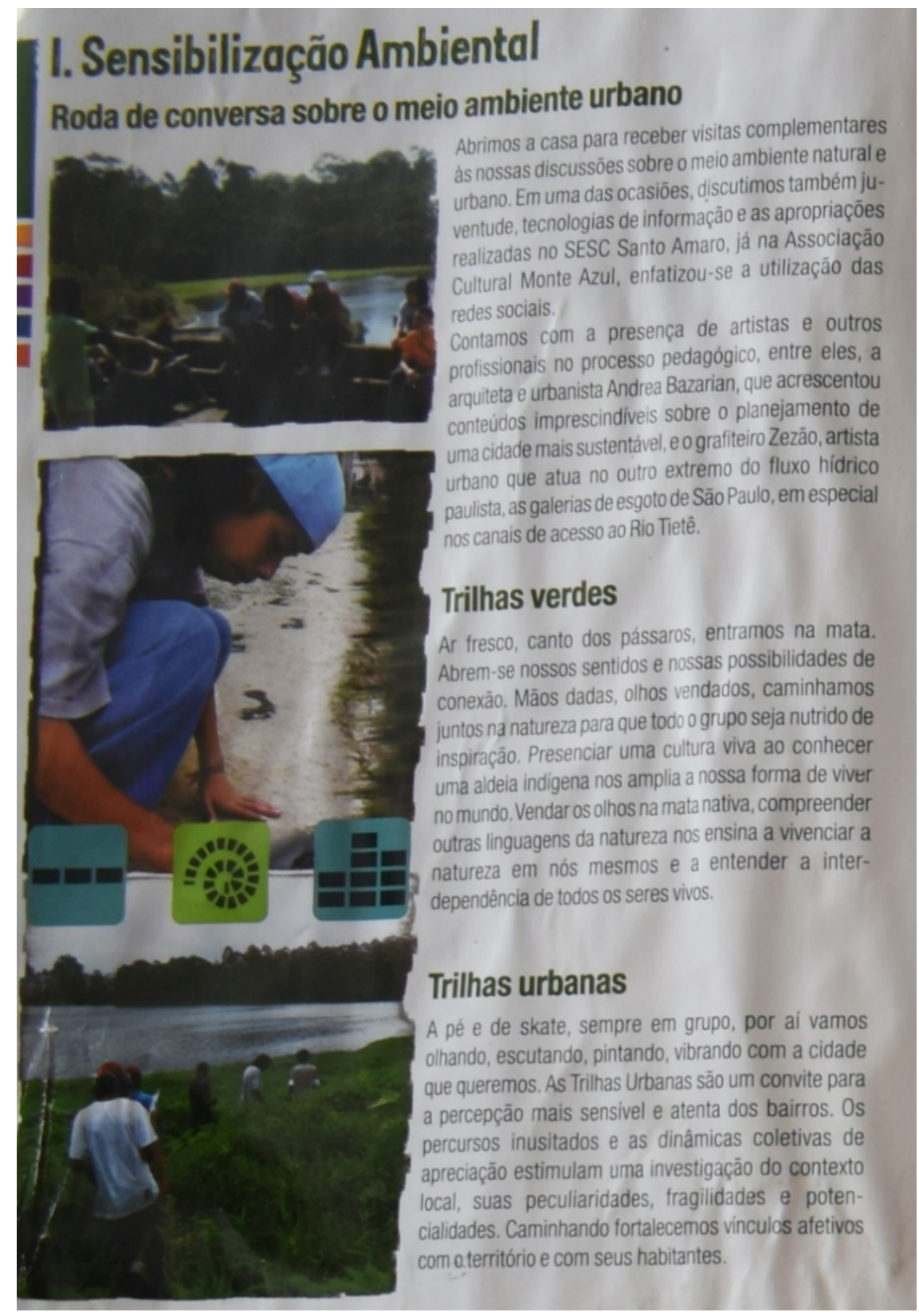

Fonte: Projeto Imargem, foto de acervo pessoal.

Ademais, o Imargem também realiza trilhas com participantes na natureza para experienciar o meio ambiente, conhecer os territórios indígenas, bem como caminhadas urbanas, tudo como um processo pedagógico para a compreensão da necessidade de preservação ambiental e do contexto de relações urbanas em que estão inseridos. Outra prática de relacionar os conceitos cotidianos com os conceitos científicos se verifica nas caminhadas realizadas pela extensão universitária no território do Bororé. 
“2. O reconhecimento da legitimidade do saber popular, da cultura do povo, suas crenças, numa época de extremado elitismo (academicismo sem prática social)” (GADOTTI, 2012, p. 23):

[...] entender que a gente já fazendo isso, o território educativo já existe, permacultura a gente já é mestre, entender que algumas chavinhas foram tiradas, desapropriadas: comida orgânica a gente já tem, em algum momento esse processo capitalista desigual tira isso, essa ancestralidade, essa oralidade e faz com que a periferia e povos marginalizados não se vejam fazendo isso, estão distantes e a gente não tem que exportar nada porque a gente que criou essa tecnologia, a gente só tem que ressignificar e ter uma conta-narrativa de entender que a gente que criou, isso nos pertence.

(PARTICIPANTE 8, entrevista concedida a Analu Garcia, 2020).

O trecho demonstra a existência de saberes populares e a consciência dos agentes locais quanto a importância desse conhecimento em suas ações práticas e elaborações simbólicas.

“3. Um método de ensino e pesquisa que parte da leitura da realidade (leitura do mundo), da observação participante. Parte do concreto, o mundo vivido dos sujeitos e setores populares. Ensino-aprendizagem inseparável da pesquisa, da cultura popular e da participação da comunidade” (GADOTTI, 2012, p. 23):

[...] em 2018 nós fizemos o primeiro trabalho que era mais ou menos isso, né, com os alunos: nós pegamos um mapa da Ilha do Bororé, né, da região, né, uma parte da Ilha do Bororé e começamos a mapear. [...] Esses pontos marcados são algumas regiões onde tem moradores, né. A nossa primeira intenção era marcar onde os alunos moravam dentro da Ilha do Bororé - no projeto e fora do projeto.

(PARTICIPANTE 3, entrevista concedida a Analu Garcia, 2019).

A cartografia emerge nos processos educativos entre a extensão universitária, a escola e o coletivo local como um método de pesquisa para compreender a realidade, bem como uma ferramenta para lançar novos olhares e representações sobre o próprio território.

“4. Uma teoria crítica do conhecimento, fundamentada numa antropologia (ser humano inacabado, incompleto, inconcluso): somos programados para aprender. Importância das 
condições de aprendizagem: ênfase nos processos e não nos resultados” (GADOTTI, 2012, p. 23):

E isso tem que ser desmistificado porque o conflito existe, né, mas como que a gente lida com esse conflito? Então por isso que a gente tenta colocar todo mundo na roda na ilha para discutir o território e não significa que não vai ter conflito [...] A gente propõe a gente trocar ideia, sabe.

[...] mas a gente tem uma barreira muito grande que é trabalho com a galera da cultura, que são assuntos que as pessoas às vezes não querem tratar como questão de gênero, como homofobia, você não pode falar, né, que o jovem pode escolher o sexo que ele quer, a orientação sexual. A gente não pode falar de intolerância religiosa, né. [...] Então a gente enfrenta todos esses essas problemáticas da sociedade, né. Então chegar dentro da escola e falar “ó você vai desenvolver um projeto da hora no seu bairro porque o seu bairro é da hora” [...] não agrada todos da comunidade porque eles querem ver o filho fazer Universidade e ir para fora - "não, ele vai morar no centro.

(PARTICIPANTE 8, entrevista concedida a Analu Garcia, 2020).

O trecho demonstra a tentativa dos coletivos de cultura de conscientizar (FREIRE, 1981) a comunidade por meio do diálogo sobre a necessidade de uma constante reformulação sobre a leitura do mundo.

“5. Uma educação como prática da liberdade, precondição para a vida democrática: educação como produção e não meramente como transmissão de conhecimentos; a educação como ato dialógico (recusa do autoritarismo), ao mesmo tempo rigoroso e imaginativo" (GADOTTI, 2012, p. 23):

[...] e aí que teve a ideia de fazer um mapeamento da Ilha do Bororé, né. Faz o mapeamento e também as entrevistas com as pessoas mais antigas, pegamos dados de como era e do que é hoje pra fazer o contraponto, como eu fiz com os alunos, eu levei daqui pro centro e para fazer esse contraponto.

(PARTICIPANTE 3, entrevista concedida a Analu Garcia, 2019).

Os processos educativos na concepção freireana são pautados em processos comunicativos dialógicos e democráticos, o que pode se verificar nas práticas (e também nos métodos) adotados no projeto Bororé ao Mundo. Nesse sentido, a troca geracional por meio da 
escuta dos moradores mais antigos contém um caráter pedagógico e ativo, tendo em vista as reelaborações simbólicas por meio de tal interação sociocultural (VYGOTSKY, 2001).

"6. Uma ciência aberta às necessidades populares: a relevância social como critério de qualidade da ciência” (GADOTTI, 2012, p. 23):

Quando a FAU veio pra cá o projeto era de sete meses, só que a coisa começou a ganhar uma dinâmica muito grande e outros grupos vieram pra cá, outras faculdades vieram para cá para conhecer a Ilha do Bororé porque ninguém conhecia, conhecia só por causa dos problemas que tinham que era abandono de cachorro, era a questão da violência, a balsa que era pequena demais, que atrasava, ficava horas aqui pra atravessar... e depois que nós começamos a fazer esse projeto veio outras faculdades e começou a dar um outro olhar pra Ilha do Bororé: não pela coisa de abandono de cachorro, de violência, ou de falta de uma balsa maior e começaram a ver a balsa com outro olhar. Isso foi legal porque? Porque começou a chamar atenção de outras pessoas, né, então outras pessoas já estão fazendo projetos em cima da Ilha do Bororé.

(PARTICIPANTE 3, Entrevista concedida a Analu Garcia, 2019).

O trecho demonstra o interesse da universidade na realização de práticas que atendam à sua função social, que se verificou nas atividades de extensão universitárias realizadas no Bororé, que contribuíram para dar maior visibilidade ao território.

“7. Harmonização entre o formal e não-formal. O direito à educação não é apenas direito de ir à escola, mas direito de aprender na escola e ter acesso a oportunidades de educação não formal (cinema, teatro, esporte, cultura, lazer...) ” (GADOTTI, 2012, p. 23):

[...] levar os alunos daqui da Ilha do Bororé para conhecer o centro da cidade, mostrar pra eles a discrepância do que é o nosso território em relação ao centro da cidade [...] saímos daqui de ônibus, fomos pro centro da cidade, nós fomos tirando fotos, mapeando o território daqui até o centro, dá mais ou menos uns 35/36 km. Do centro nós saímos a pé da Praça da República até o Mercado Municipal e nós fomos mostrando, fomos mostrando pra eles a quantidade de praças que não eram praças, construções antigas misturadas com construções novas, um emaranhado de bagunça e o contraponto da gente aqui.

(PARTICIPANTE 3, entrevista concedida a Analu Garcia, 2019). 
A utilização de espaços não formais como instrumento pedagógico é ilustrada no trecho acima, que ressalta a tentativa de formação de consciência das crianças quanto à existência de discrepâncias territoriais entre o centro urbano e o território que estão inseridas.

“8. A utopia como verdadeiro realismo do educador, opondo-se ao fatalismo neoliberal que nega o sonho de outro mundo possível” (GADOTTI, 2012, p. 23):

Esse é o caminho, é a cultura, educação! Tomara que a galera saque que é isso, que a gente tá trazendo um pouco de discussão, cultura, educação, se encontrar, permacultura, natureza, que as pessoas podem ser livres, que descentralizar não é um problema, você acumular riqueza talvez não seja legal. "Por que que você não revê isso? Olha, tá vendo? Acumular riqueza não dá certo”. Porque é legal, é gostoso fazer uma coisa coletiva, descentralizar o poder. A gente não precisa ter tudo para gente, então são coisinhas básicas que tomara que a galera saque, né, que a partir daí entenda que as comunidades estão fazendo isso há bastante tempo...

(PARTICIPANTE 8, entrevista concedida a Analu Garcia, 2020).

Verifica-se no trecho acima a utopia como mola propulsora das atividades voltadas à transformação do status quo.

“9. A educação como direito humano, direito de se emancipar, combinando trabalho intelectual com trabalho manual, reflexão e ação, teoria e prática, conscientização e transformação, a organização, o trabalho e a renda (economia popular solidária) ” (GADOTTI, 2012, p. 23):

Então qual foi a ideia: a realização do território e ao mesmo tempo mantendo a condição de que quem mora na Ilha pudesse trabalhar aqui na própria Ilha, não precisar atravessar a represa pra ir trabalhar do outro lado, ou seja, gerar emprego dentro do próprio território sem que as pessoas saíssem. E aí começou o nosso trabalho.

(PARTICIPANTE 3, entrevista concedida a Analu Garcia, 2019).

O trabalho a que se refere o trecho destacado da entrevista é o projeto Bororé ao Mundo. O que demonstra que a prática educativa tem objetivos de transformação social e geração de renda. 
Portanto, os elementos acima apresentados indicam que as práticas verificadas no território do Bororé podem ser classificadas como práticas de educação popular na visão freireana. É importante registrar que a verificação da adequação das práticas à educação na concepção de Paulo Freire se deu pela análise do material coletado em campo.

\subsection{Perus ${ }^{71}$}

O bairro de Perus, de onde eu venho, ele sempre foi um bairro dormitório, um bairro afastado do centro de São Paulo.

(PARTICIPANTE 6, entrevista concedida a Diego Fernandes, 2019).

Perus é um distrito do município de São Paulo localizado no extremo noroeste da capital, com extensão territorial de 57,2 km², área equivalente a 3,8\% do município. Ao sul de Perus se situa o Pico do Jaraguá e ao norte, divididos pelo rios Juqueri e Pinheirinho, os municípios de Cajamar e Caieiras. A região é administrada pela Subprefeitura de Perus, que também abrange o distrito de Anhanguera (PREFEITURA DO MUNICÍPIO DE SÃO PAULO, 2016) ${ }^{72}$.

\footnotetext{
${ }^{71}$ Parte deste capítulo é composto pelo texto apresentado ao XII Seminario Internacional de Investigación en Urbanismo, Sao Paulo/Lisboa, Dezembro de 2020, com a anuência do orientador. Cf Borges (2020, no prelo Março de 2021).

72 Cf. Caderno de Propostas dos Planos Regionais das Subprefeituras Quadro Analítico - Secretaria Municipal de Desenvolvimento Urbano - SMDU/SP, 2016.
} 


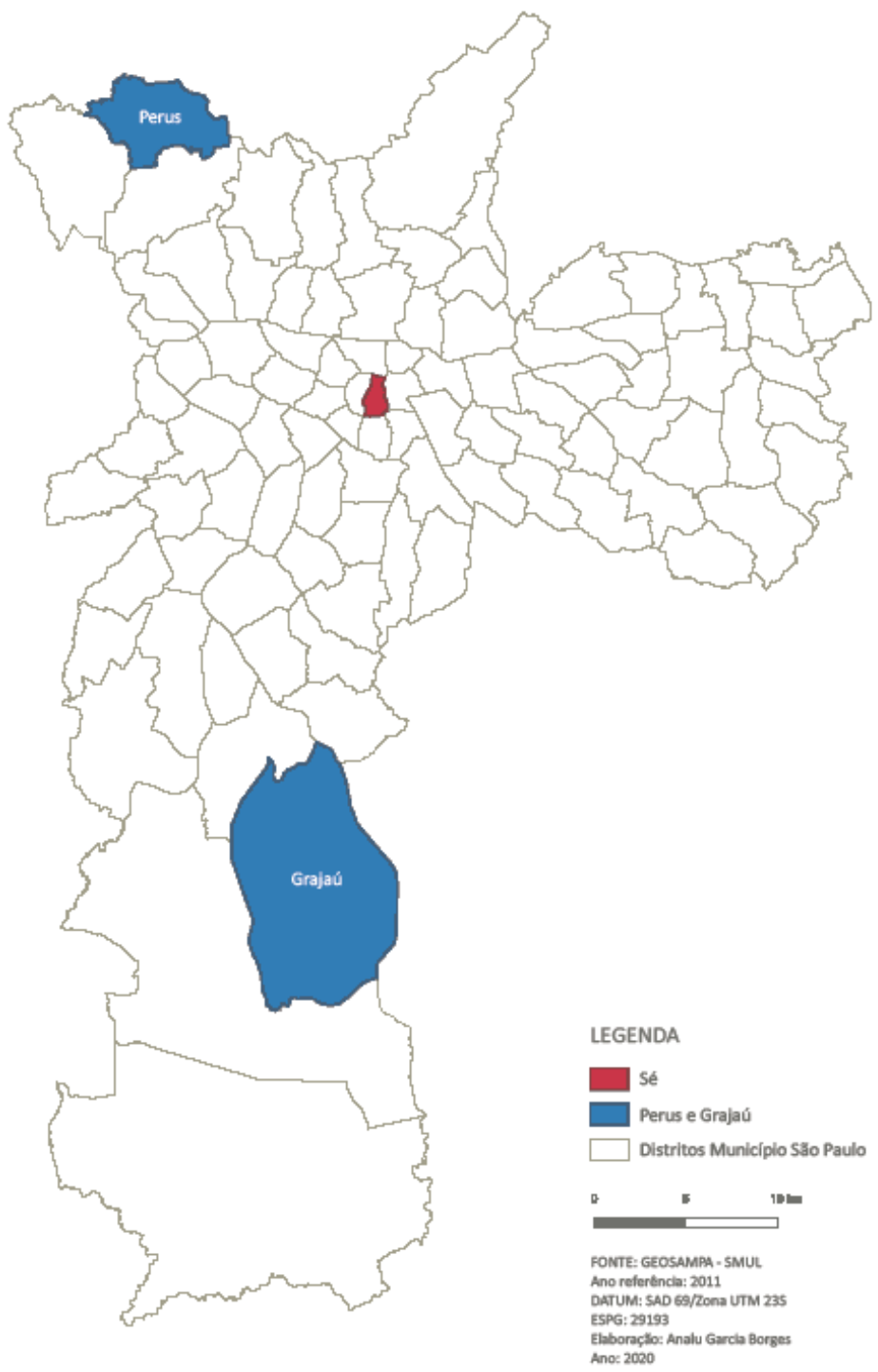

Fonte: Secretaria Municipal de Licenciamento - SMUL/SP. Elaboração: autora. 


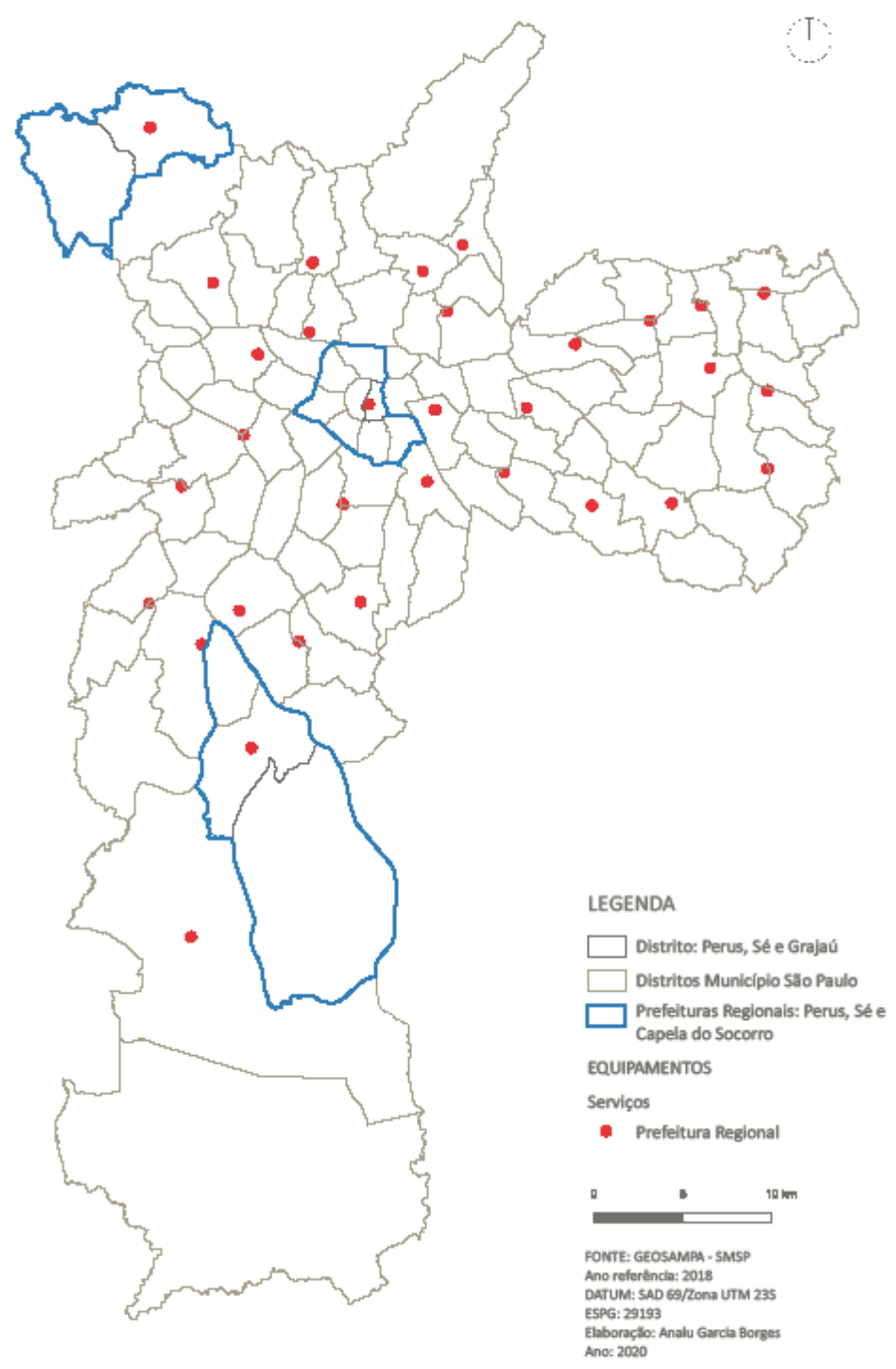

Fonte: Secretaria Municipal de Subprefeituras - SMSP/SP. Elaboração: autora.

Apesar das altas taxas de crescimento populacional entre os anos de 1980 e 2010 (3\%), comparado ao restante do município, Perus apresenta densidade demográfica baixa (34,2 hab/ha) e, em 2010, a sua população se encontrava nos grupos 5 e 6 de maior vulnerabilidade com 50\% da população empregada e apenas 25\% ganhando mais que 03 salários mínimos em 
valores da época. A subprefeitura de Perus apresenta um dos mais baixos IDH da cidade $(0,73)$ (PREFEITURA DO MUNICÍPIO DE SÃO PAULO, 2016) ${ }^{73}$.

Mapa 17 - Índice Paulista de Vulnerabilidade Social aplicado ao município de São Paulo

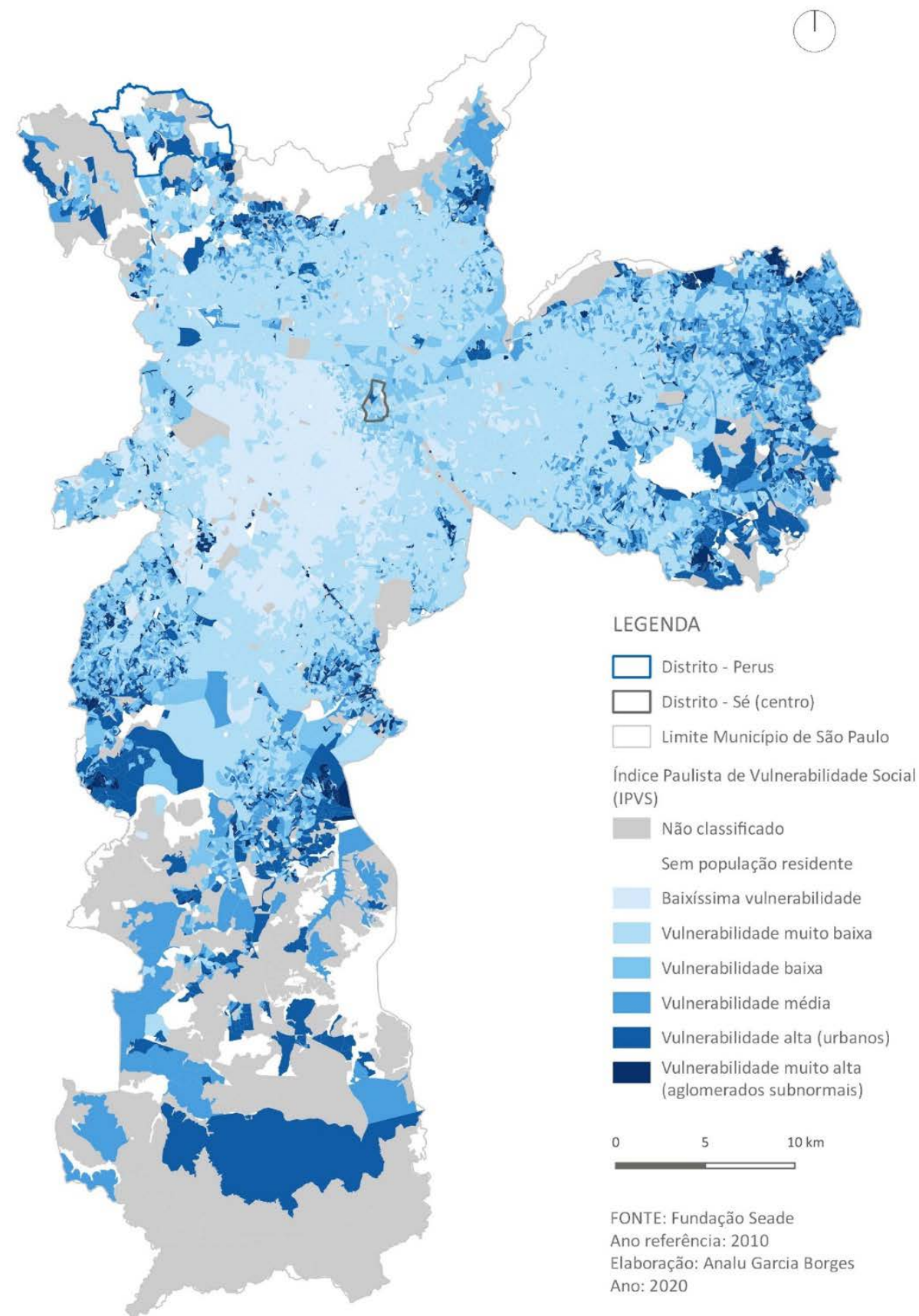

Fonte: elaboração própria com base nos dados da Fundação Seade 2010.

${ }^{73}$ Cf. Caderno de Propostas dos Planos Regionais das Subprefeituras Quadro Analítico - Secretaria Municipal de Desenvolvimento Urbano - SMDU/SP, 2016. 
O primeiro núcleo urbano formado na região localiza-se onde hoje é o atual distrito de Perus, que no último quarto do século XIX servia de ponto de apoio para a rede de circulação da economia cafeeira por meio da Estrada de Ferro da São Paulo Railway e, mais tarde, no início do século XX, serviu à circulação de cal entre Cajamar, Perus e São Paulo. Com a implantação da primeira Fábrica de Cimento do Brasil - a Fábrica de Cimento Portland Perus fundada em 1924 - os vetores de urbanização orbitaram em torno da estação ferroviária da Estação Perus e da fábrica. Esses dois pontos do território constituíram-se como campos de atração populacional, tanto nacional quanto internacional, e a criação das vilas operárias Triângulo e Inácio (PREFEITURA DO MUNICÍPIO DE SÃO PAULO, 2016) ${ }^{74}$.

A formação territorial de Perus se deu por conflitos que marcaram a história, a memória e o território, como a instalação da Fábrica de Cimento e a greve dos 7 anos (1962-1969), com as reivindicações trabalhistas do Sindicato dos Trabalhadores “da Cimento Perus”. Alguns anos após seu fechamento em 1987, iniciou-se um movimento para que a fábrica fosse tombada e desapropriada para a criação de Centro de Lazer, Cultura e Memória do Trabalhador. Desse modo, a caracterização do bairro de Perus como um bairro operário remete à sua constituição, mas também às lutas operárias que ocorreram a partir de meados do século XX. A categoria “trabalho” é fundamental na constituição desse território e de sua territorialidade, configuradas por relações de forças dissimétricas, trazendo a abordagem proposta por Raffestin (1993), e pela consequente mobilização e conscientização política da população afetada por esses conflitos.

Figura 76 - Ilustração com a representação da Estação Ferroviária de Perus

Fonte: idealização da autora, elaboração Camilla Ortega.

\footnotetext{
${ }^{74}$ Cf. Caderno de Propostas dos Planos Regionais das Subprefeituras Quadro Analítico - Secretaria Municipal de Desenvolvimento Urbano - SMDU/SP, 2016.
} 


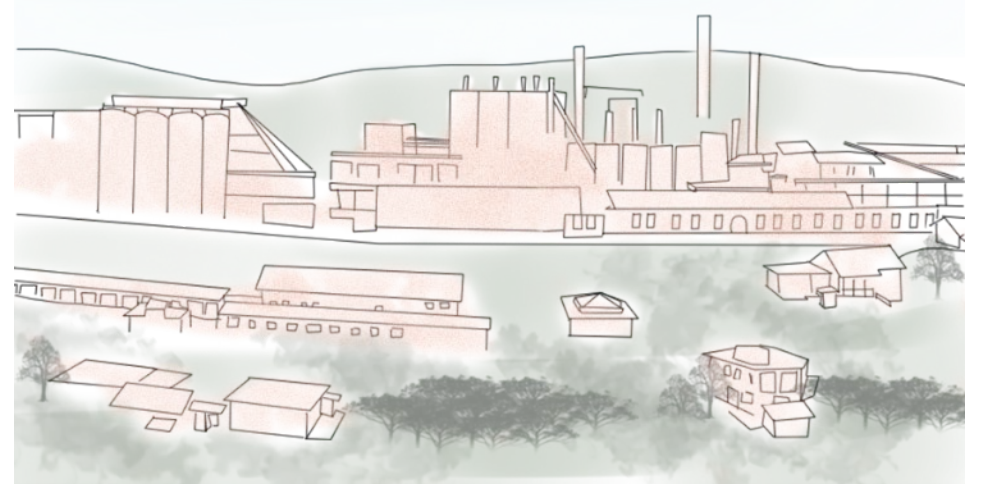

Fonte: idealização da autora, elaboração Camilla Ortega.

Outra marca territorial da macrorregião 2 são as Rodovias que a cortam - Rodovia Anhanguera, Bandeiras - e o Rodoanel Mário Covas. Tais eixos de circulação configuram os fluxos macrorregionais de importância econômica no país, contudo, fragmentam o território e as territorialidades locais, dificultando o acesso entre os distritos e a mobilidade na escala do sujeito, isto é, a mobilidade a pé. Tal como a indústria e a mineração, presentes na região, a implantação de eixos viários também se configura como um vetor de ocupação e expansão urbana.

Mapa 18 - Conexão dos terminais Perus e Anhanguera, destacando a conexão horizontal, em oposição ao recorte feito no território pela Rodovia dos Bandeirantes.

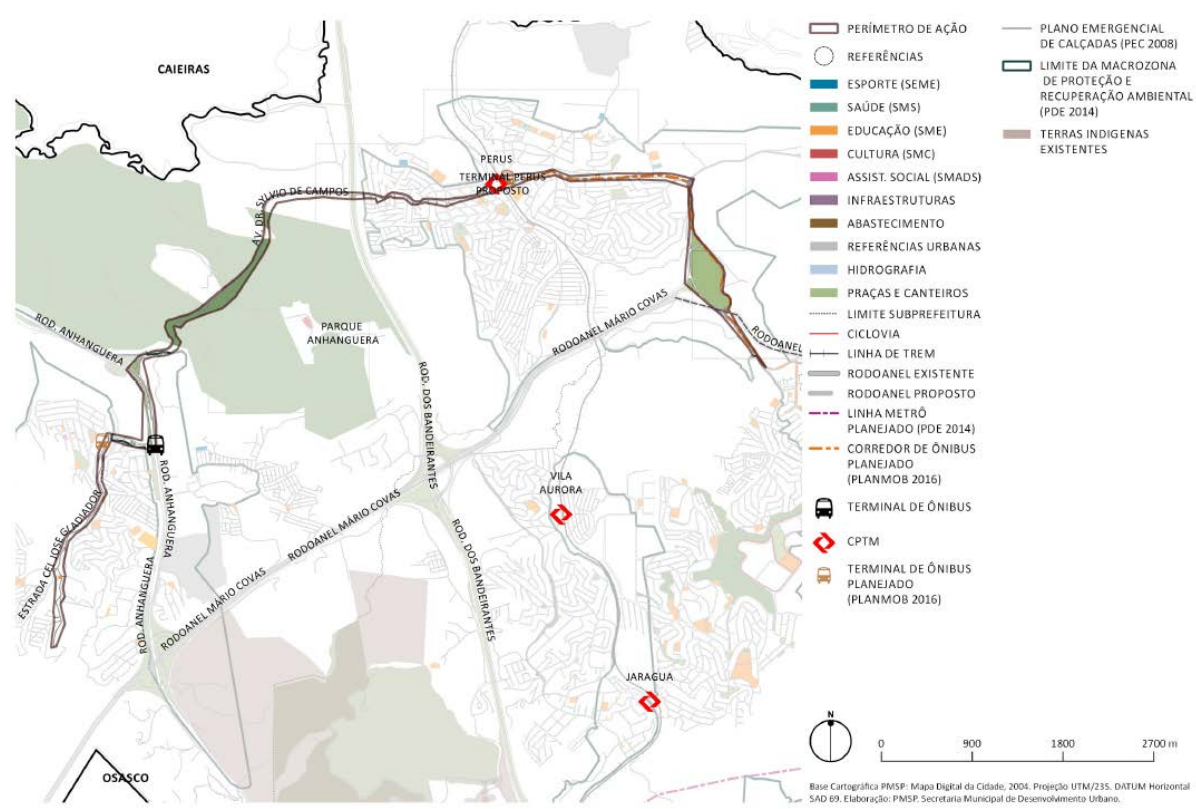

Fonte: Caderno de Propostas dos Planos Regionais das Subprefeituras Perímetros de Ação - Secretaria Municipal de Desenvolvimento Urbano - SMDU/SP, 2016. 
Essa estruturação territorial também afeta a condição ambiental, fragmentando e dificultando a conectividade ecológica entre os parques presentes na região, como o Parque Anhanguera, o Parque Estadual do Jaraguá, Parque Estadual da Cantareira, Parque Pinheirinho D’Água e outros parques planejados, como o Parque Linear Ribeirão Perus, o Parque Aterro Bandeirantes, Parque Luta dos Queixadas etc. (PREFEITURA DO MUNICÍPIO DE SÃO PAULO, 2016). Ademais, os problemas relacionados ao aterro, popularmente conhecido como "lixão", e às enchentes, devido ao relevo acidentado, bem como à ocupação irregular do solo, configuram uma condição de vulnerabilidade social e ambiental alta na região, com áreas de ZEIS 1 e 2 em grande proporção do território.

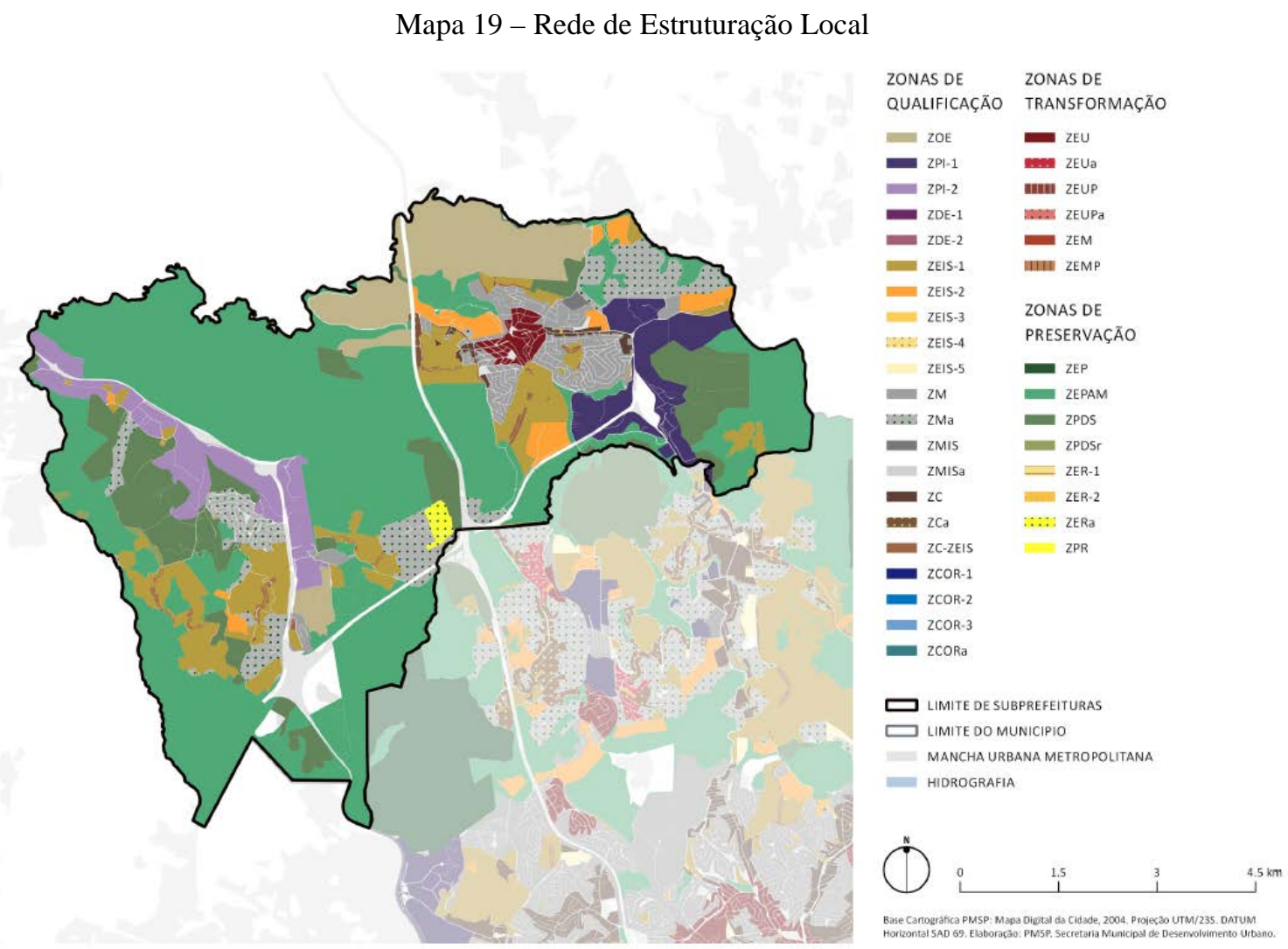

Fonte: Caderno de Propostas dos Planos Regionais das Subprefeituras Quadro Analítico - Secretaria Municipal de Desenvolvimento Urbano - SMDU/SP, 2016.

O baixo nível de atividade econômica e de qualidade de vida da população contrastam com a riqueza histórica, ambiental e cultural do local. A macrorregião norte 2 do município de São Paulo, onde o distrito de Perus se localiza, possui peculiaridades relacionadas ao patrimônio cultural, histórico e ambiental, como os parques da Cantareira, Anhanguera e Jaraguá, Aldeia 
Guarani, as cavas de ouro do século XVI, a Ferrovia Perus-Pirapora, a estação ferroviária Jaraguá, a Fábrica de Cimento Portland Perus e o cemitério Dom Bosco, local da vala comum clandestina de Perus, onde foram encontradas ossadas de desaparecidos políticos durante o período de ditadura militar no Brasil. A riqueza material e imaterial desse território tem servido à atuação política e pedagógica de diversos grupos do território, como os coletivos de cultura, educação, movimentos sociais e universidade.

\subsection{As práticas educativas em Perus: o exercício pedagógico e político da construção coletiva da memória e do conhecimento}

Figura 78 - Foto da Fábrica de Cimento de Perus.

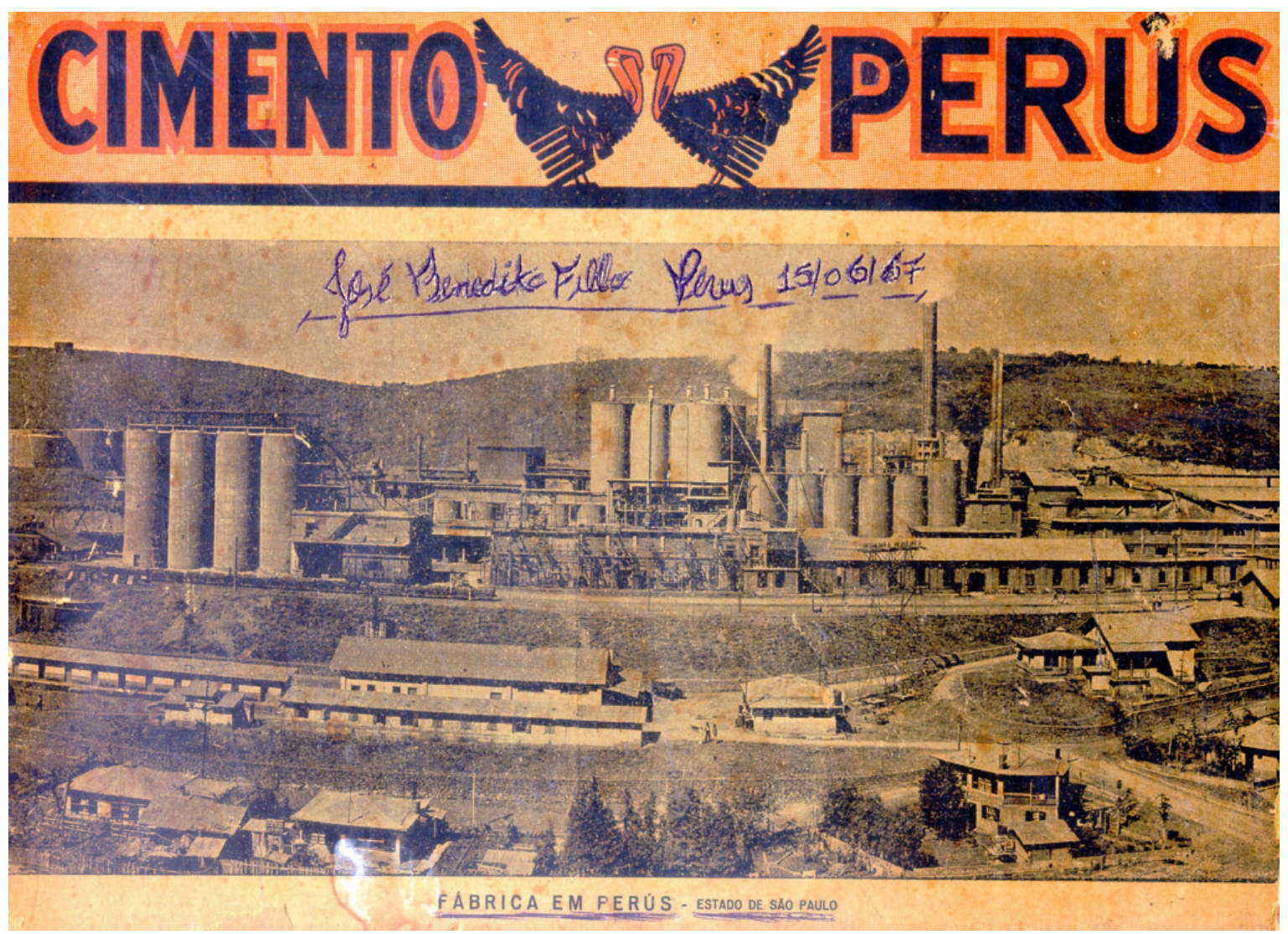

Fonte: acervo Nelson Camargo. Disponível em: https://movimentofabricaperus.wordpress.com/. Acesso em 10 dez 2020.

É um lugar onde aconteceu a maior greve Operária da história, 7 anos de greve. É um lugar em que o lixão foi tirado pelo movimento popular, enfim, tem história de trabalhador e de luta muito bonita e marcante em Perus. E acho que isso marca todas as outras lutas, né, atuais, dos movimentos de cultura, de arte, né, dos movimentos de 
moradia, enfim. Eu acho que é um lugar especial, assim, na cidade. Todo mundo deveria conhecer essa história de Perus, né...

(PARTICIPANTE 11, entrevista concedida a Analu Garcia, 2020)

As marcas territoriais da formação de Perus e de sua região constituíram, em grande parte, o aprofundamento de relações dissimétricas e a formação de territórios de vulnerabilidade social e ambiental. Contudo, tal realidade tem sido apropriada por meio da ação e mobilização política de sujeitos organizados coletivamente, buscando reconstruir narrativas e aproveitar de modo sustentável os recursos naturais que ainda restam na região. Ademais, o vórtice de forças desse território continua em processo de disputa por meio da valorização da memória operária, símbolo das lutas urbanas e do exercício da cidadania em Perus. A reivindicação da Fábrica de Cimento como símbolo do Trabalhador permeia diversos momentos desde sua constituição, no final da década de 1980, e se renova com a aderência de novos sujeitos e pautas, a partir de $2011^{75}$, quando se inicia um processo coletivo e colaborativo de construção de conhecimento para a resolução de um conflito que envolvia o poder público e a comunidade, que seria removida para a implementação do Parque Linear Ribeirão Perus. Dentre os ameaçados de remoção encontrava-se a Comunidade Cultural Quilombaque.

Figura 79 - Foto dos operários da Fábrica de Cimento de Perus

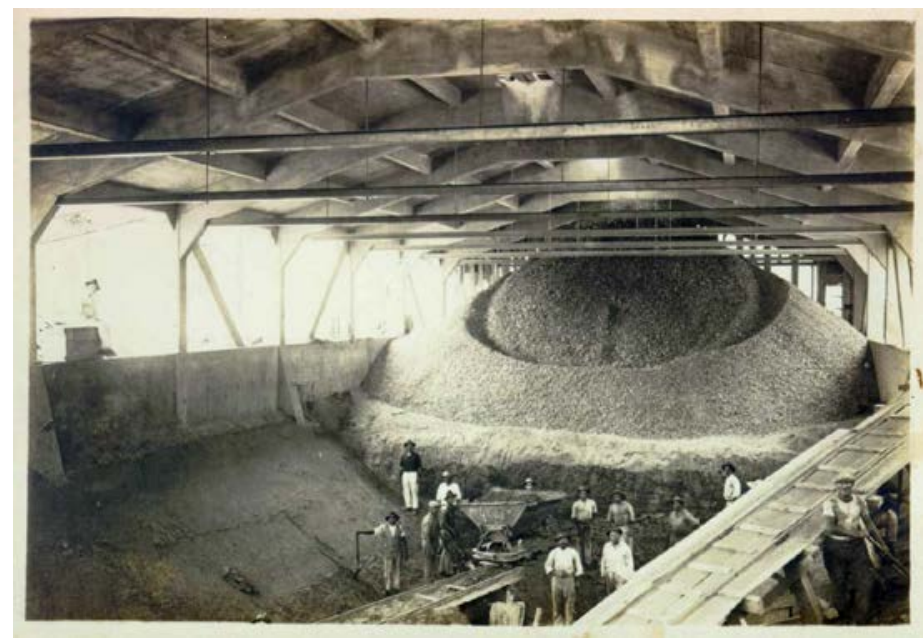

Fonte: acervo Nelson Camargo. Disponível em: https://movimentofabricaperus.wordpress.com/. Acesso em 10 dez 2020.

75 Atualmente o Movimento pela Reapropriação da Fábrica de Cimento agrega, além das organizações e movimentos locais, como Associação dos Aposentados de Perus, Associação Queixadas, o Sindicato de Cimento de Perus, a Comunidade Cultural Quilombaque, Sociedade Amigos do Bairro de Perus (SADIP) e as Comunidades Eclesiais de Base (CEBs), agentes externos, como o Núcleo de Estudos de Paisagem (NEP/USP), o Programa de Educação Tutoriada de História da Faculdade de Filosofia, Letras e Ciências (FFLCH/USP) e Projeto Coruja (MOVIMENTO FÁBRICA PERUS, [s.d.]). 
Figura 80 - Foto dos operários da Fábrica de Cimento de Perus

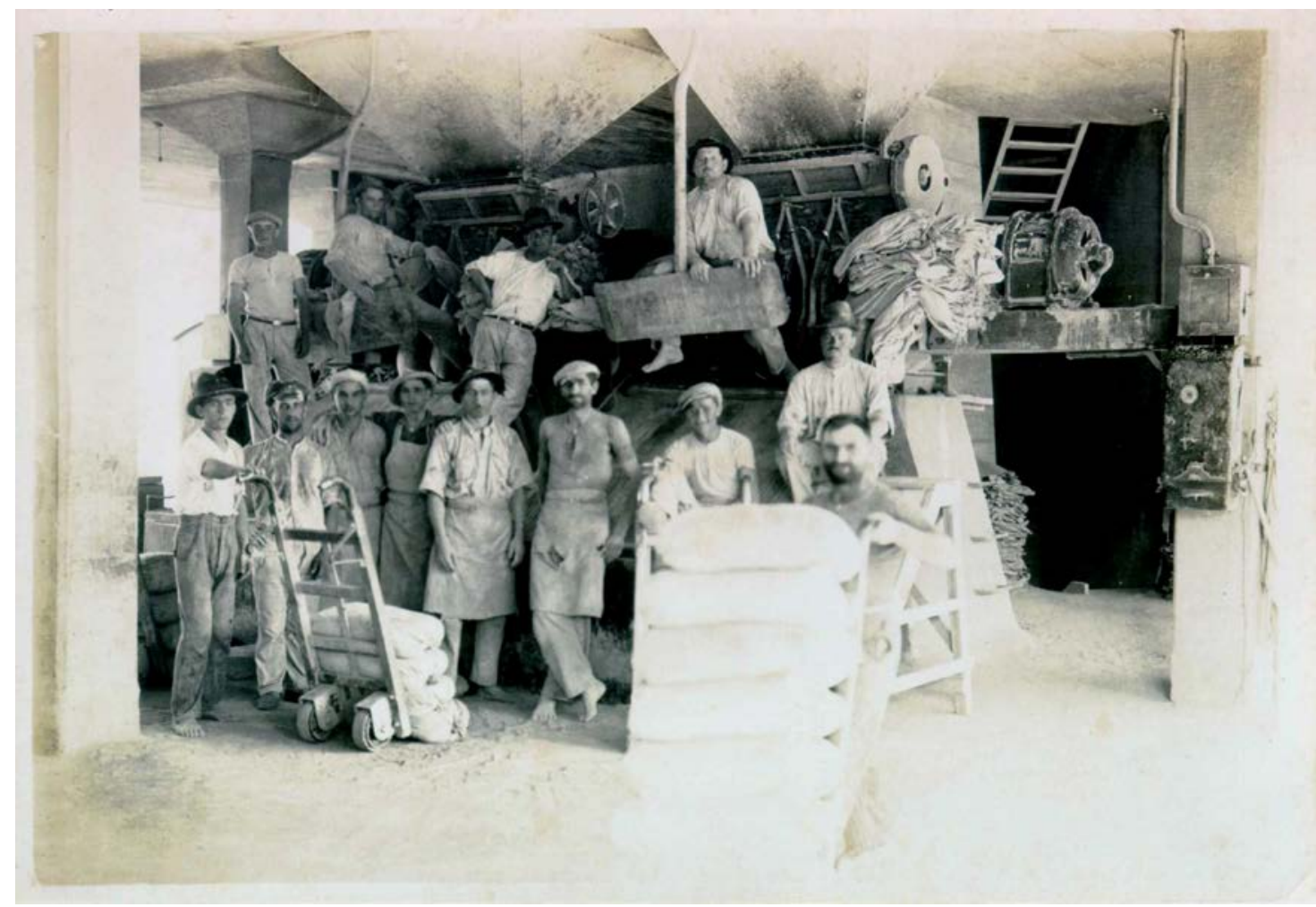

Fonte: acervo Nelson Camargo. Disponível em: https://movimentofabricaperus.wordpress.com/. Acesso em 10 dez 2020.

Figura 81 - Greve dos operários da Fábrica de Cimento de Perus

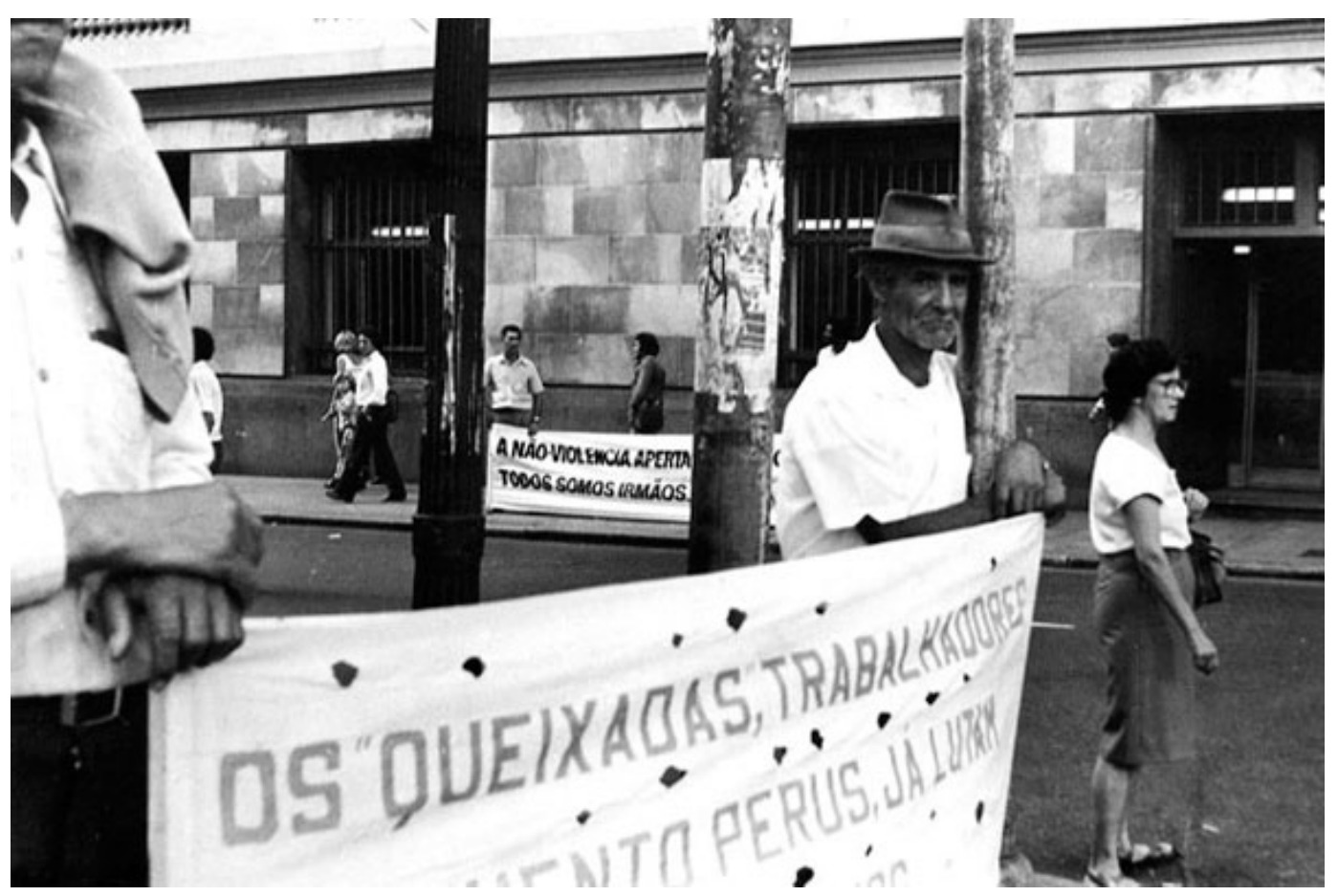

Fonte: acervo Sindicato de Cimento Perus. Disponível em: https://movimentofabricaperus.wordpress.com/. Acesso em 10 dez 2020. 
Figura 82 -Greve dos operários da Fábrica de Cimento de Perus

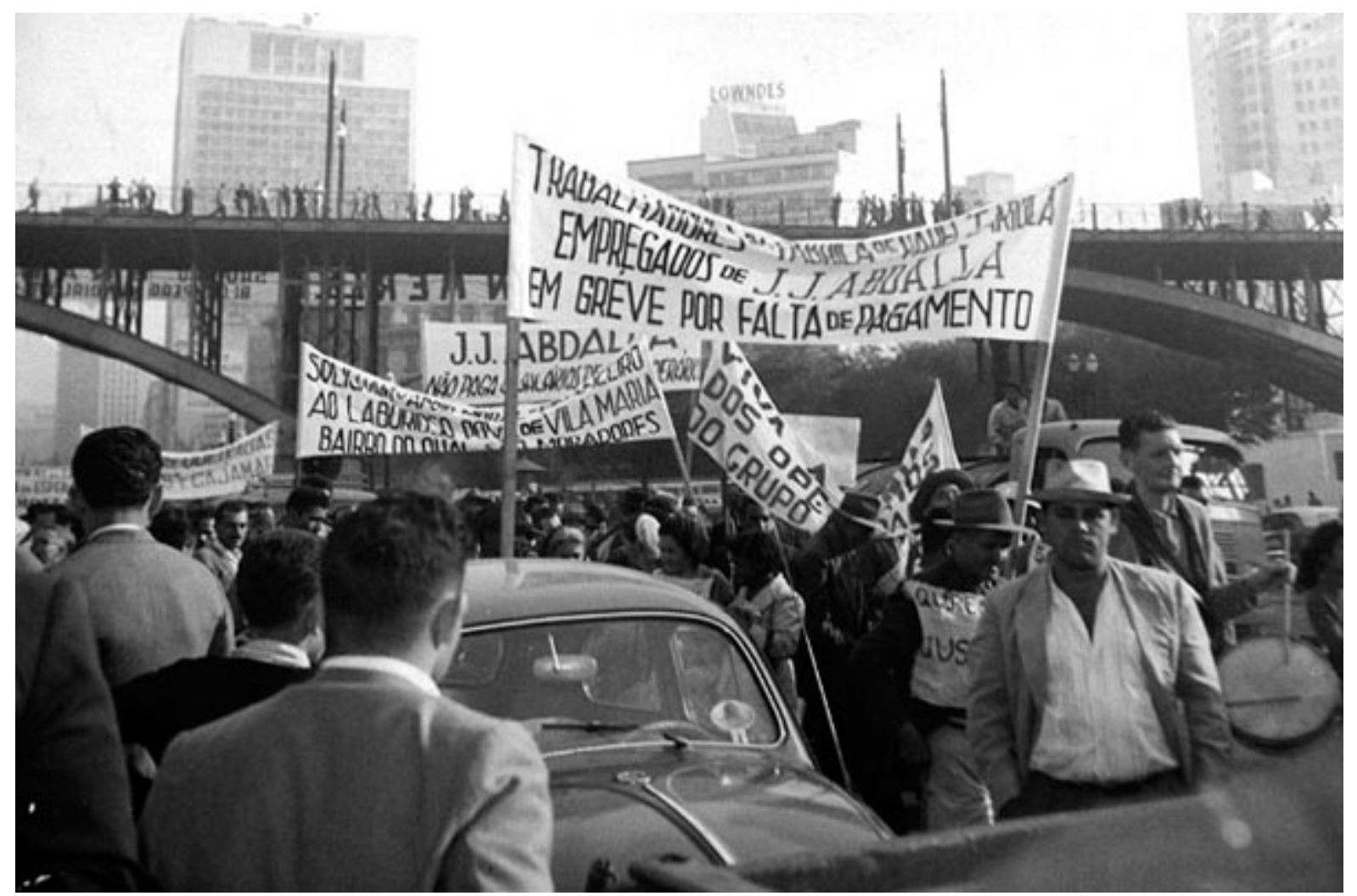

Fonte: acervo Sindicato de Cimento Perus. Disponível em: https://movimentofabricaperus.wordpress.com/. Acesso em 10 dez 2020.

\subsubsection{Comunidade Cultural Quilombaque}

Quem é que está produzindo hoje? É os movimentos culturais, não tinha mais nenhuma representatividade nem da igreja, nem política nas periferias e nós já tínhamos a concepção de que nós somos o trabalho de base e também porque era uma realidade muito distinta.

(PARTICIPANTE 1, entrevista concedida a Analu Garcia e Diego Fernandes, 2019).

[...]aí tem o B.O. do Parque Linear, né. Então a Quilombaque, ela vira referência cultural, mas também vira referência de luta social. Então toda atividade de... tinha alguma manifestação [...] sempre tinha algum B.O. para resolver, o pessoal chamava a gente.

(PARTICIPANTE 10, entrevista concedida a Analu Garcia, 2020). 
Figura 83 - Logotipo da Comunidade Cultural Quilombaque

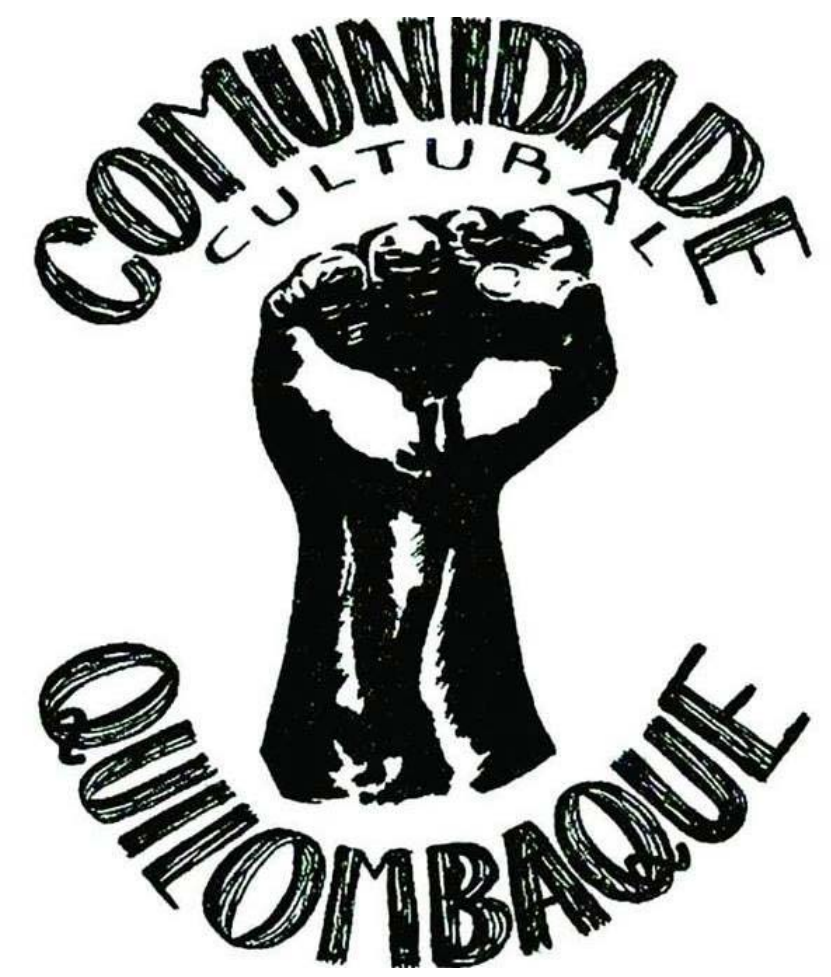

Fonte: Comunidade Cultural Quilombaque. Disponível em: https://www.facebook.com/quilombaque/ . Acesso em 10 dez 2020.

A Comunidade Cultural Quilombaque foi criada em 2005 pela iniciativa de jovens de Perus, inicialmente como um grupo de percussão, sob a influência da cultura afro-brasileira "Qui de quilombos e baque de batidas dos tambores, né!”76. O grupo, que no começo de sua formação se apresentava no centro da cidade, passou a estabelecer conexões com outros agentes locais, como o Projeto Coruja ${ }^{77}$ e artistas locais. Desse modo, passou a diversificar as linguagens e expressões, começando assim a demarcar seu território em Perus e na cidade, estabelecendo redes com outros artistas e coletivos de cultura.

[...] e aí veio outros, diversos artistas compareceram lá, de outras manifestações, né, pessoal do teatro, outros artistas começou a frequentar o espaço. E aí foi que a gente pensou em abrir esse espaço para mais linguagem, não só percussão... E aí a gente abre o espaço, começamos a fazer aula de teatro, tinha libras, aula de libras, interpretação de texto para o pessoal do vestibular, né.

(PARTICIPANTE 10, entrevista concedida a Analu Garcia, 2020).

\footnotetext{
${ }^{76}$ Entrevista concedida a Analu Garcia, 2020.

${ }^{77}$ O Projeto Coruja era um projeto de formação ligado à Igreja Católica e a lideranças do bairro (informação verbal).
} 
A importância que a Comunidade Cultural Quilombaque adquire no bairro está ligada a diversos aspectos relacionados à ancestralidade afro-brasileira, presente em suas manifestações artísticas e ações políticas, como também às ações comunitárias que o coletivo desempenha junto de outros agentes do bairro.

A gente conta desde a luta dos indígenas, né, na aldeia e o processo de colonização que teve, o processo de escravidão que aconteceu e isso vai apagado lá no contexto histórico do território e teve a primeira leva de angolanos chegou no nosso território e sumiu... A gente tava fazendo um estudo de um cemitério de escravo ali no pé do lixão e dos quilombos que existiram na região de Pirituba, isso foi apagado da história. E aí você tem que ter muita pesquisa para tentar descobrir alguma coisa, né... Então nessa questão que a gente tenta trazer a luta de preservação do patrimônio material e imaterial.

(PARTICIPANTE 10, entrevista concedida a Analu Garcia, 2020).

Então a gente tem avançado muito em entender o que é essa interferência, essa modificação, a gente se dedicou muito a entender como é que funciona. É fundamental memória, resgate da memória, produção de conhecimento, a ideia de reapropriação, que ela não é nossa, essa é nossa cidade, nosso lugar, portanto vamos cuidar dele. Porque se você quiser enfrentar a violência, a miséria, enfrentar o lixo, a poluição, eu durante muitos anos acreditei na educação ambiental, na psicanálise eu fui entender que se o sujeito não tiver o mínimo de ligação afetiva com o território não rola.

(PARTICIPANTE 1, entrevista concedida a Analu Garcia e Diego Fernandes, 2019).

Figura 84 - Comunidade Cultural Quilombaque, 2019
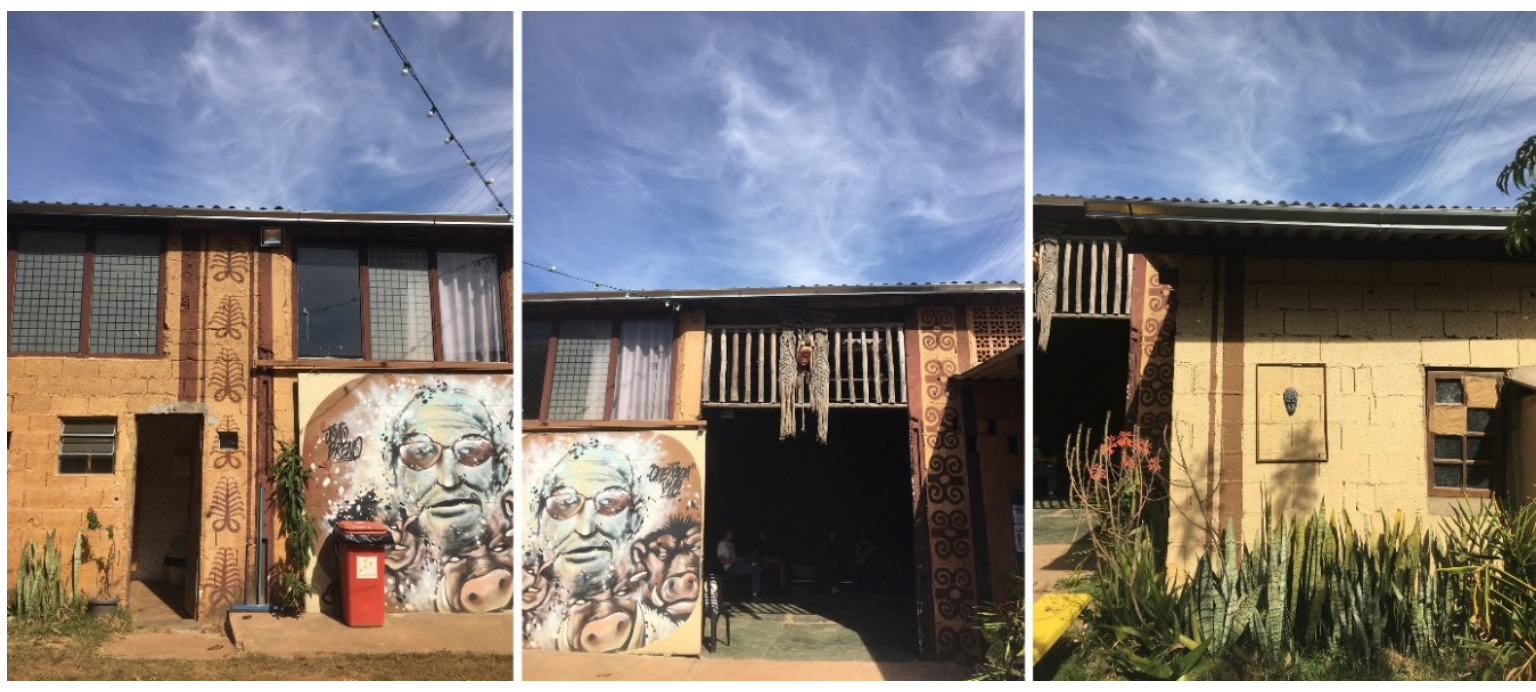

Fonte: acervo pessoal. 
A Quilombaque convive com “múltiplas territorialidades” (HAESBAERT, 2019) e dimensões educacionais: com a cultura afro-brasileira, por meio de cursos de percussão, conformando processos de educação não formal. Além de transitar por processos de educação não formal, nas atividades do coletivo há uma predominância do caráter político nas ações educativas, com aspectos de educação popular, notadamente por meio da valorização da cultura afro-brasileira. Um exemplo disso pode ser verificado por meio da atuação do cursinho popular da Uneafro $^{78}$, sediado na Quilombaque. Ainda, somado a esses processos, há um movimento de ação educacional comunitária quando agentes do território, como o CIEJA Perus I e as escolas do bairro, reúnem-se nesse lugar para colaborarem com a formação dos participantes. Por estarem territorializados e por utilizarem referências do território em suas reflexões educativas, há um processo de elaboração simbólica ocasionado pelo processo dialético da prática seguida de reflexão, mediados pela “interação sociocultural” (VYGOTSKY, 2001).

A “multiterritorialidade” da Comunidade Cultural Quilombaque ocorre também na decodificação de múltiplos territórios para além de seu próprio quilombo urbano, por meio da realização de Trilhas Educativas, cujas dimensões pedagógica e territorial promovem o exercício de conscientização sobre a memória local. As trilhas tiveram início em 2012 e faziam o roteiro que contava a história da Fábrica de Cimento, atualmente já são onze trilhas.

Então cada coisa que a gente se meter tem que virar referência, a biblioteca ressignificada, não em biblioteca igual àquela, o dinamismo, quase 24h por dia, tem teatro. Tem uma Trilha da ressignificação que explica como se ressignifica espaços públicos. Tem a trilha que a gente chama de Memória Queixada, ela completa, ela é assim: ela segue o sentido histórico, a fábrica, a ferrovia Perus-Pirapora até o Gato Preto [...]. São onze trilhas em Perus até agora. A gente pede pras pessoas saírem da luz e chegar no território de trem. E são trilhas de propor reflexão. Então as trilhas cumprem papel político e são basicamente de formação. E a gente faz essa formação toda integrada com o corpo e com a mente, e você vai criando uma espécie de experiência de aprendizado. E pra compreender isso, né, mas a gente usa a fábrica na Trilha Queixada pra construir a luta que a gente luta há 30 anos pra tomar aquela fábrica e transformar num lugar de memória dos trabalhadores. Faz parte da luta a trilha. Isso já nos levou a sentar com o Abdalla, e discutir o futuro da fábrica, tamanho o impacto que a trilha gerou com a movimentação toda; são exercícios de

\footnotetext{
${ }^{78}$ Uneafro. Disponivel em: https://uneafrobrasil.org/. Acesso em: 13 dez 2020.
} 
fortalecimento político e quando a gente faz pra gente de fora, universidade, a gente tá divulgando, angariando apoio.

(PARTICIPANTE 1, entrevista concedida a Analu Garcia e Diego Fernandes, 2019).

Outra atividade pedagógica de dimensão territorial desenvolvida pela Quilombaque consiste na proposta do Museu Territorial Tekoa Jopo’i, um museu aberto que utiliza os potenciais do território como forma de valorização do patrimônio local e de geração de renda para a comunidade. A realização dessas atividades configura o que o coletivo denomina de turismo de resistência, pois reconta a história a partir da memória local e promove a geração de renda sobre e a partir do território, de modo sustentável e educativo.

Figura 85 - Ilustração com a representação do Museu Territorial Tekoa Jopo’i.

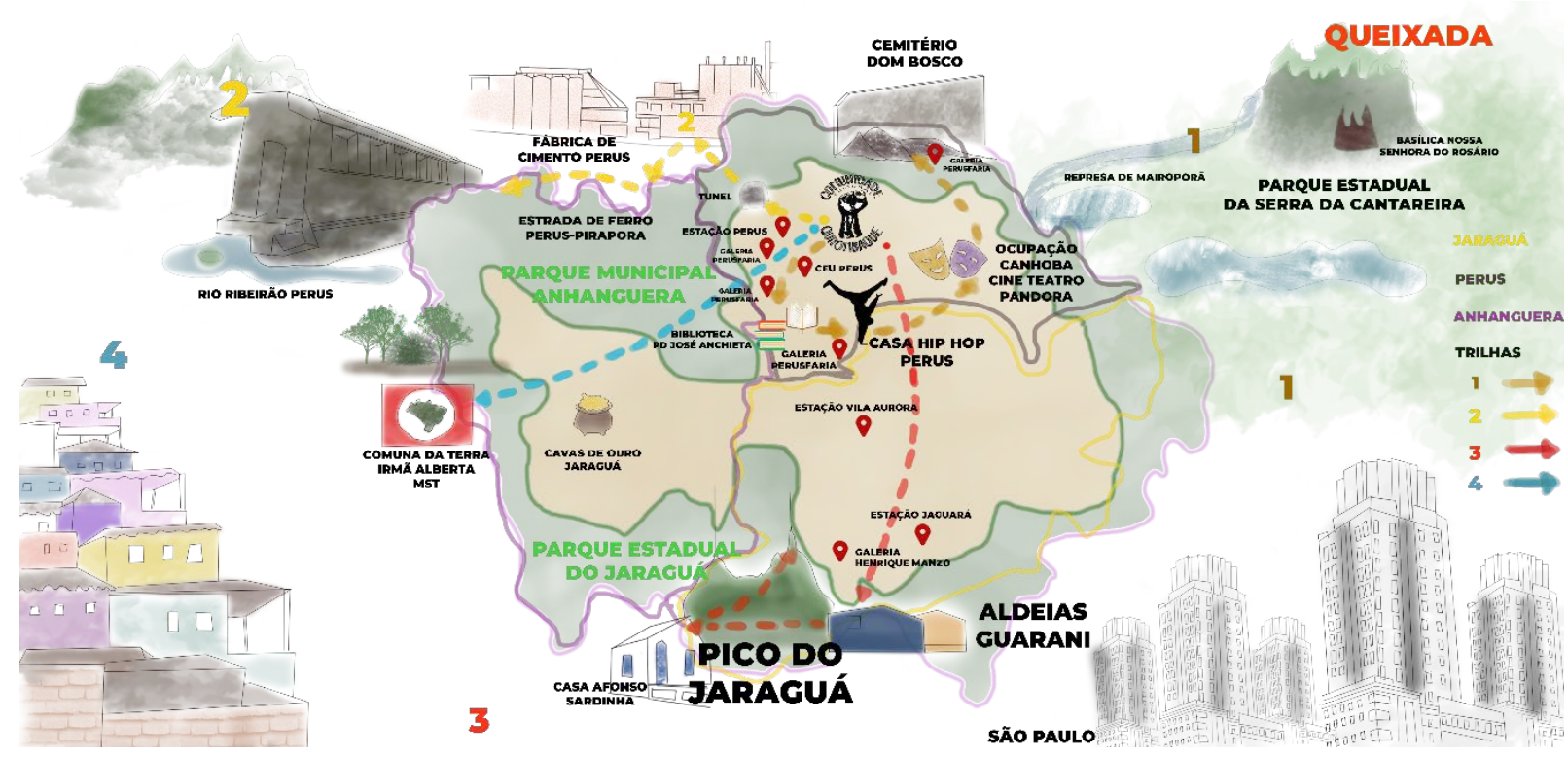

Fonte: idealização da autora, elaboração Camilla Ortega, com base no cartaz elaborado pela Comunidade Cultural Quilombaque.

O coletivo está imerso em processos de lutas urbanas e mobilização política, com discursos e ações atrelados ao "direito à cidade" no sentido de luta reivindicatória (HARVEY, 2014). Destaco ainda que tais lutas também se encontram vinculadas ao conceito de servirologia cunhado por José Queiroz (Soró), uma das lideranças da Quilombaque: “se você tem você faz, se você não tem você faz do mesmo jeito, VOCÊ SE VIRA! ” $\left(\right.$ SOUZA, 2020) ${ }^{79}$. Essa construção de referência proporcionada pela ação do coletivo atua como sua "marca territorializante” (DELEUZE E GUATTARI, 1993). 


\subsubsection{Universidade Livre e Colaborativa (ULC)}

Figura 86 - Linha do tempo com fatos relevantes sobre a Universidade Livre e Colaborativa

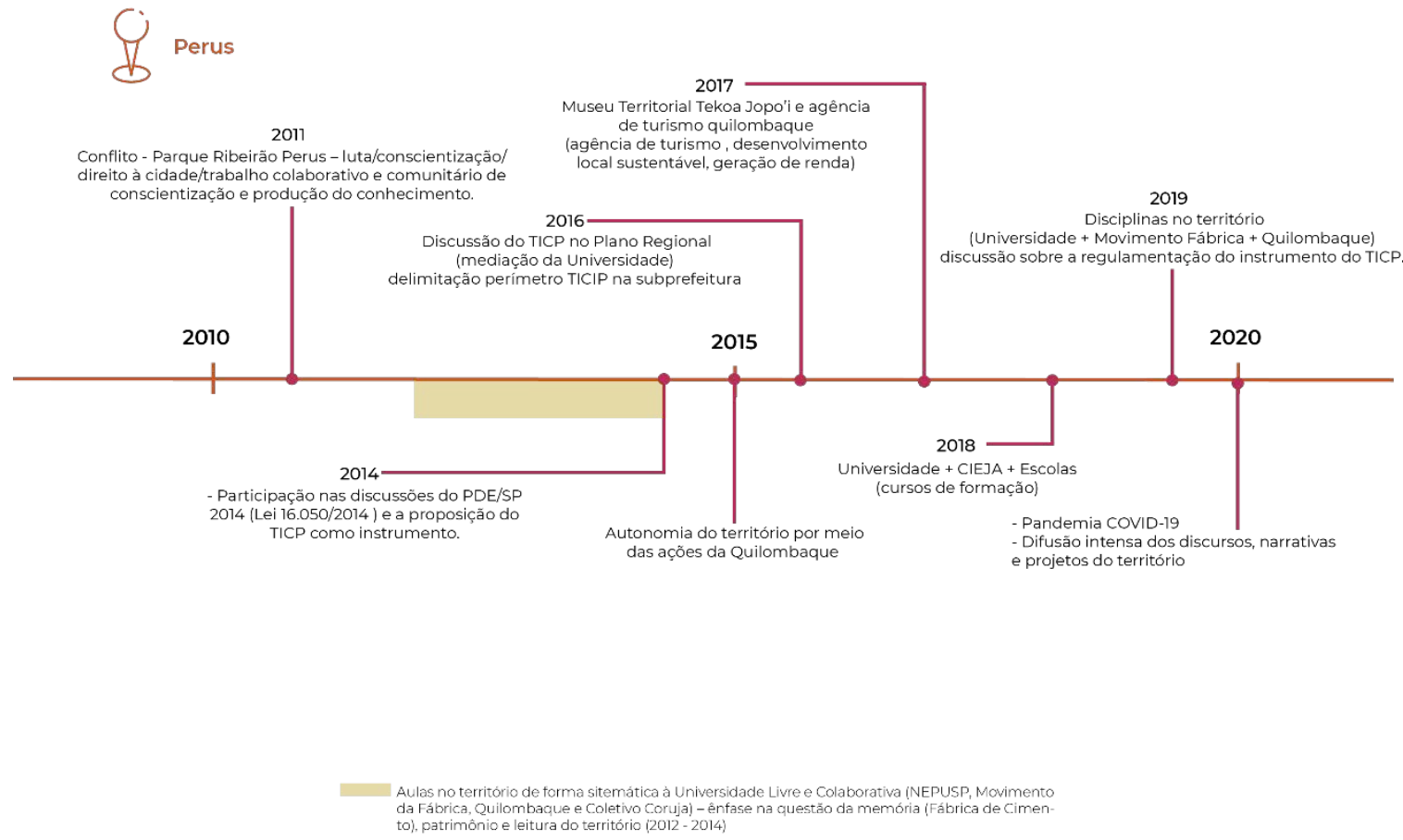

Fonte: idealização da autora, elaboração Camilla Ortega.

A partir de 2011, deu-se o início da parceria entre a Comunidade Cultural Quilombaque, do Projeto Coruja e do Núcleo de Estudos da Paisagem (NEP) da Universidade de São Paulo (USP), que juntos constituíram a Universidade Livre Colaborativa (ULC), em prol da construção de conhecimentos de modo partilhado entre universidade e comunidade, por meio de práticas pedagógicas relacionadas às questões urbanas, ambientais e sociais da região de Perus. Segundo Sandeville Jr (2018), o programa da ULC se desenvolveu a partir da parceria entre o NEP, cujos princípios se pautavam na integração de ensino, pesquisa e extensão, e moradores de Perus, por meio de ações dialógicas no âmbito da cultura, da aprendizagem e da pesquisa participante. Inicialmente, a parceria surgiu a partir da tentativa de formulação de alternativas ao projeto do Parque Linear Ribeirão Perus, que se deu sem efetiva participação da comunidade e cuja implementação previa a remoção de diversos moradores da região, inclusive da Comunidade Cultural Quilombaque. A partir dessa experiência de estudo do território e das dinâmicas urbanas, alguns desdobramentos e pautas passaram a ser perseguidas pelo grupo de 
forma a construírem propostas para o desenvolvimento local, com adesão do Movimento pela Reapropriação da Fábrica de Cimento de Perus e de questões importantes para a memória local.

A aproximação entre a universidade e a comunidade se deu por um conflito de caráter emergencial, tendo em vista a iminência de um processo de remoção. Desse modo, a dimensão do direito à cidade (HARVEY, 2014) e da conscientização (FREIRE, 1981) por meio do olhar investigativo sobre e no território emergem de maneira vigorosa nessa primeira fase de trabalho da ULC. Nos relatos das entrevistas emergem as questões relacionadas aos conflitos e confrontos inerentes ao processo, mas também a rica troca entre os agentes durante esse projeto em comum, verificados especialmente por meio das experimentações metodológicas colaborativas, não formais, bem como da mobilização da linguagem cartográfica e de linguagens criativas.

[...] aí ele se propôs a uma outra coisa que era assim: a gente tava começando uma ideia de articular todo o eixo ao longo do rio, a gente pegava um filme que chamava "Narradores de Javé" e ia pelas comunidades discutindo essa coisa do pertencimento, dos afetos, a partir do filme. O Euler falou "nós precisamos investir muito no entendimento do que é um Parque Linear para não simplesmente ser contra, mas fazer uma crítica consistente” e ele entrou nessa parada de capacitação dos moradores ao longo do rio. Então a gente ia com filme, ele com um monte de mapa e aí fazíamos várias reuniões com as populações dos lugares explicando o que que era parque linear, o que que era planejamento urbano. Foram 4 ou 5 meses de exercício de capacitação. (PARTICIPANTE 1, entrevista concedida a Analu Garcia e Diego Fernandes, 2019).

Entre 2012 e 2014 as disciplinas começam a ser elaboradas no território de maneira sistemática, organizadas junto com a comunidade, esse processo foi chamado de Universidade Livre e Colaborativa de construção de conhecimento de forma horizontal, a partir das problemáticas do território e da incorporação da linguagem do planejamento urbano. Nesse momento as principais pautas estavam relacionadas à memória e ao patrimônio, notadamente à Fábrica de Cimento de Perus, com processos de leitura da paisagem para o reconhecimento dessas dimensões e dos processos urbanos e ecológicos. Com o envolvimento de professores nas discussões da Universidade Livre e Colaborativa, houve também uma ampliação da participação de escolas nas discussões sobre a memória local. 
Figura 87 - Pontos importantes do território de Perus - lugares de identidade e memória

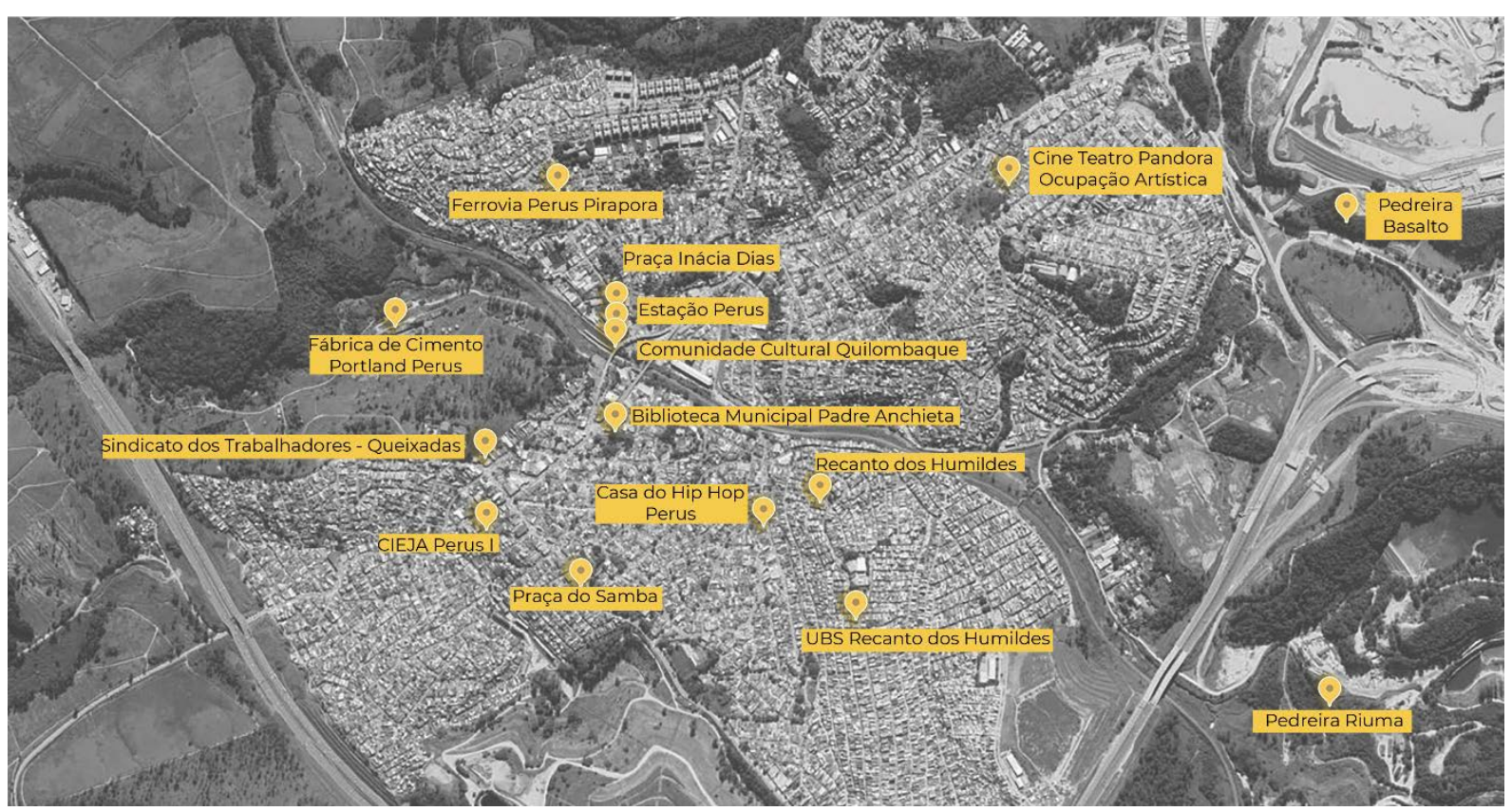

Fonte: idealização da autora, elaboração Camilla Ortega, com base em imagem do Google Earth.

Mergulhos mesmo no território, aulas em tudo quanto é buraco, ribanceira. Foi uma experiência bem bacana e ela foi se desenhando no que a gente chamou de Território de Interesse da Cultura e da Paisagem.

(PARTICIPANTE 1, entrevista concedida a Analu Garcia e Diego Fernandes, 2019).

Em 2014 o grupo adentra às discussões sobre o Plano Diretor e amplia os debates em nível municipal, disputando narrativas e espaços (territorializando-se) na esfera pública com os códigos do Planejamento Urbano. O acúmulo de estudos sobre o território durante os dois anos anteriores culminou na proposição do instrumento urbanístico do TICP e sua inclusão no Plano Diretor Estratégico de São Paulo (PDE/SP 2014). O artigo 314 do PDE (Lei nº 16.050/14) conceitua o TICP como:

[...] áreas que concentram grande número de espaços, atividades ou instituições culturais, assim como elementos urbanos materiais, imateriais e de paisagem significativos para a memória e a identidade da cidade, formando polos singulares de atratividade social, cultural e turística de interesse para a cidadania cultural e o desenvolvimento sustentável, cuja longevidade e vitalidade dependem de ações articuladas do Poder Público. 
Desse modo, a conscientização das condições territoriais desiguais possibilitou o desenvolvimento de projetos político-pedagógicos no território, através da atuação da ULC. A práxis educativa no território contribui para a formação cidadã na medida em que conscientiza os indivíduos a respeito de si e do mundo, bem como os coloca diante do exercício do direito à cidade, como se deu, por exemplo, na instituição do TICP no PDE-SP.

Eu tô lá no meio da aula de repente eu falo com o pessoal “olha sábado que vem vai ter aula aos sábados, vai ter audiência, né, a gente tá estudando, por que que a gente não vai lá e vê o que que eles estão discutindo e vê se o que está sendo discutido a gente tem algum conhecimento”. E foi bárbara experiência. Isso trouxe uma dimensão nova na disciplina e a gente começou a participar. Quando começou o Plano Diretor a gente tinha coisas a levar ao Plano Diretor, haviam cartografias do Plano Diretor que tinham equívocos que porque a gente enxergava em detalhe a gente podia contribuir para corrigir. E haviam demandas locais que o Plano Diretor não conseguia ver ou até devia por outros interesses contrários às necessidades locais, e a gente foi construindo. Foi aí que vai sair, por exemplo, a proposta dos territórios de interesse da cultura e da paisagem. Esse conhecimento é tão ativo, ele é tão poderoso e essa interpenetração com a realidade permitiu com que a gente interferisse na realidade não só para construir conhecimentos solidariamente, mas para buscar soluções solidariamente, entendeu?

(PARTICIPANTE 9, entrevista concedida a Analu Garcia, 2020)

Mapa 20 - Território de Interesse da Cultura e da Paisagem (TICP Jarguá-Perus)

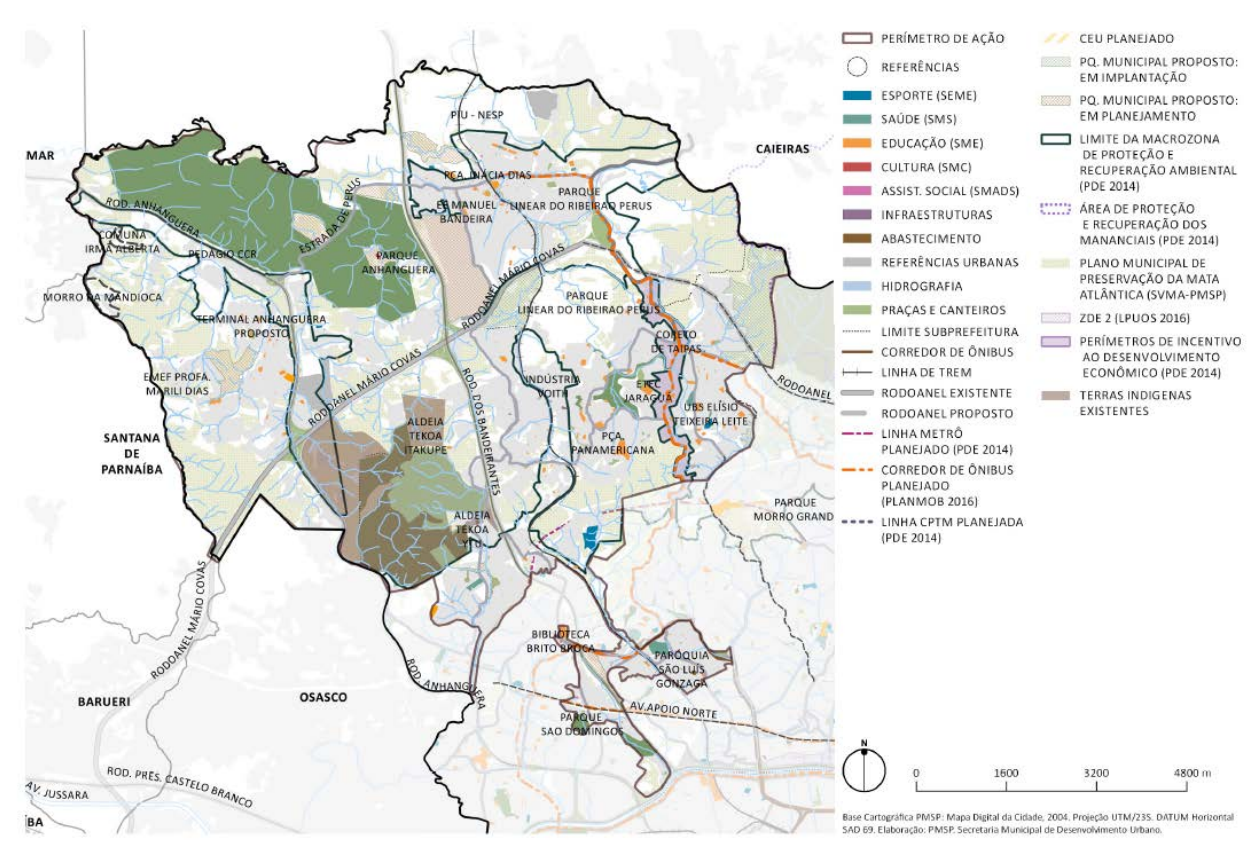

Fonte: Caderno de Propostas dos Planos Regionais das Subprefeituras Perímetros de Ação - Secretaria Municipal de Desenvolvimento Urbano - SMDU/SP, 2016. 
Figura 88 - Material gráfico produzido pela Universidade Livre Colaborativa (ULC)

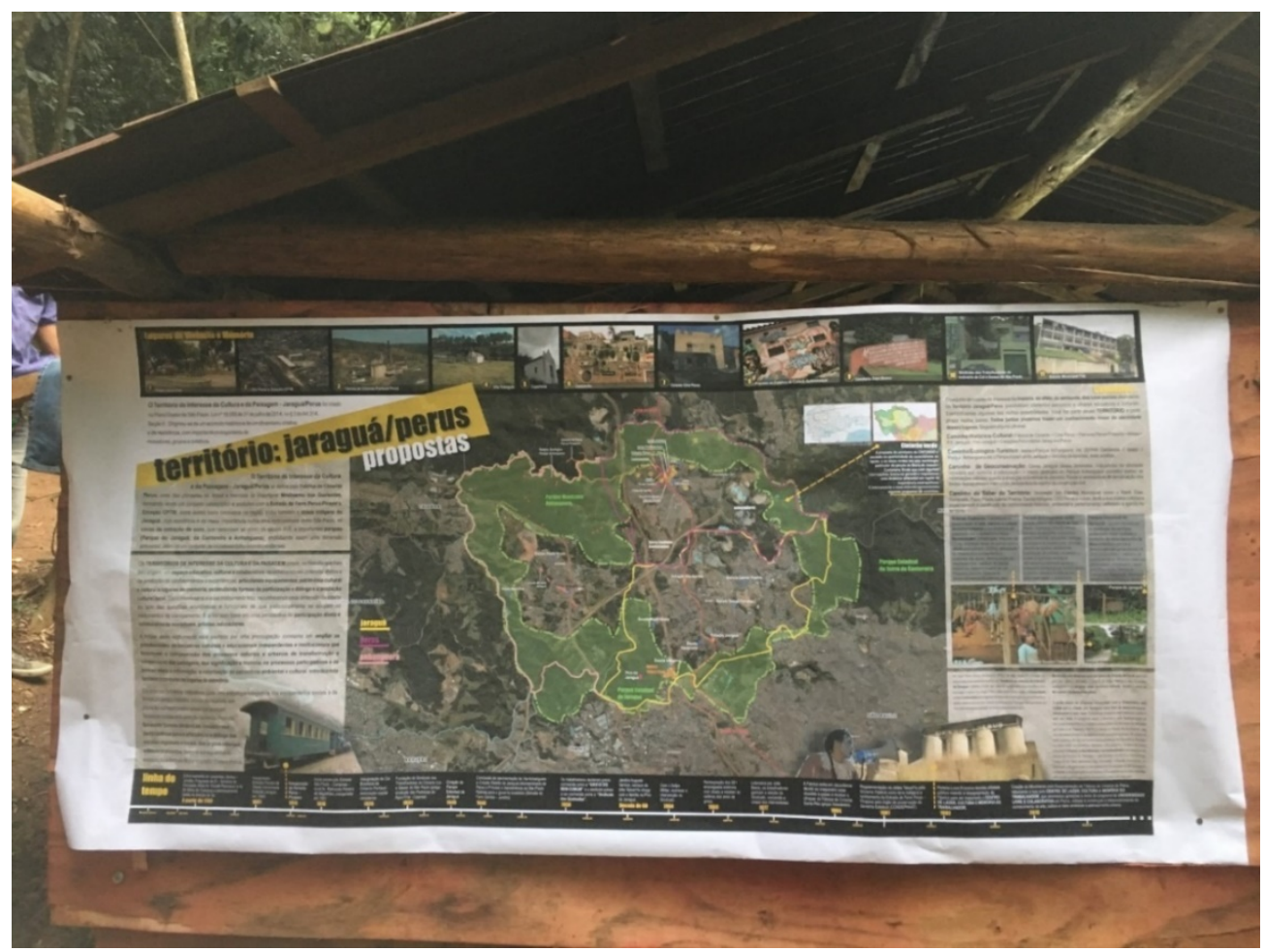

Fonte: acervo pessoal.

A partir de 2015 o processo ganha certa autonomia no território com a condução de propostas pela comunidade de forma independente, como foi o caso do Museu Territorial Tekoa Jopo’i, proposta pela Comunidade Cultural Quilombaque em 2017, com o intuito de colocar em prática a proposta de desenvolvimento territorial de base local. Em 2016 as mediações com o poder público ocorreram novamente diante da elaboração dos planos regionais nas subprefeituras e da delimitação perímetro TICP.

Na perspectiva que a gente tem é desenvolver através da memória, da preservação da nossa região porque o TICP é um instrumento muito importante para gente fazer enfrentamento para especulação Imobiliária porém a gente não tem dinheiro para o enfrentamento... Os caras vem, compra, acaba com a memória, com o patrimônio e já era.... A gente vê é o que tá acontecendo lá na Aldeia, né, que os cara ocupam uma parte da Aldeia, quer construir 11 Torres de prédio dentro de uma área de proteção ambiental, né... E aí a gente tem esse desenvolvimento nessa perspectiva de gerar renda para dentro dos bairros e os bairros ter esse desenvolvimento que não seja das pessoas acordar cedo, pegar o trem para o centro atrás de subemprego e sim morar e trabalhar na mesma região, já garanti meu uns 10 anos de vida de pegar transporte público...

(PARTICIPANTE 10, entrevista concedida a Analu Garcia, 2020). 
O Território de Interesse Cultural e da Paisagem seria uma concretização de uma ideia de território que na prática, nós de Perus, os moradores, vimos fazendo desde os anos 80, que nós chamamos de corredor cultural. Onde a gente, claro com muito menos pretensão, a gente só pensava num corredor que atingisse a biblioteca, o sindicato e territórios escolares, que eram envolvidos na luta pela transformação da Fábrica de Cimento em um Centro de Cultura e Memória do Trabalhador. Aí nos anos 80 pra frente uma atividade mais cultural [...] Todo mundo meio que pensando nessa forma de fazer cultura e transmitir para as novas gerações um modelo de vida que a gente achava mais interessante e saudável, baseado na solidariedade, na não-violência, na luta pela dignidade. E essas lutas pela cultura e educação vão se somando a outras lutas que são estruturais. Nessa configuração nenhum setor fica de lado, é como se cada área e cada fragmento que a gente faz das nossas vidas pudessem se juntar num único desenho e ali ele conversar para poder desenvolver o bairro de forma sustentável.

(PARTICIPANTE 6, entrevista concedida a Diego Fernandes, 2019).

A partir de 2018 novos processos são desencadeados baseados na concepção do TICP, como a aproximação do NEP/USP com o CIEJA Perus I e de escolas do território, com enfoque para discussões e cursos de formação relacionados à saúde, à educação, à cultura e à paisagem. As disciplinas também foram retomadas e realizadas no território de forma a discutir a regulamentação do instrumento. A participação na disciplina realizada em 2019, intitulada “Territórios de Interesse da Cultura e da Paisagem”, possibilitou a territorialização em Perus.

As aulas foram ministradas em diversos locais dos distritos de Perus e Jaraguá, como na Comunidade Cultural Quilombaque, no Sindicato Queixada, no CIEJA Perus, na aldeia indígena Guarani localizada no Parque Estadual do Jaraguá, no Cine Teatro Pandora Ocupação Artística Canhoba, na Escola Municipal de Ensino Fundamental (EMEF) Deputado Rogê Ferreira, entre outros. Os temas norteadores da disciplina focaram as questões sobre Patrimônio Histórico, Políticas Públicas e da Paisagem. As atividades centravam-se na interpretação das dinâmicas e processos naturais relacionados aos processos urbanos, em suas diversas escalas, bem como da correlação de forças dos diversos agentes que compõem o poder local nas tomadas de decisão e de vetores de especulação imobiliária que incidem sobre o território.

O processo buscava pensar soluções quanto aos problemas utilizando o TICP, a fim de extrair as potencialidades do instrumento previsto no PDE, tendo em vista que instrumento não foi regulamentado. Inicialmente foram estudados conceitos e métodos relacionados à ecologia 
da paisagem para que, posteriormente, pudessem ser realizadas leituras sobre os territórios e territorialidades de Perus, Anhanguera e Jaraguá, com intuito de se formular propostas para conectividade ambiental, integração dos equipamentos públicos e das práticas artísticas, culturais e educacionais dos agentes locais, bem como a geração de renda e o desenvolvimento sustentável, com foco nas áreas de vulnerabilidade social.

A combinação de métodos de análise da paisagem com a visão do território experienciado pelos moradores enriqueceu de modo significativo as investigações sobre o território. O trabalho em grupos para a investigação e o desenvolvimento de cartografias temáticas possibilitou a troca de saberes entre estudantes da pós-graduação da FAUUSP com moradores de Perus. A contribuição dos integrantes foi dada pela troca dos conhecimentos prévios dos integrantes. Por exemplo, a relação da Quilombaque com a aldeia indígena, ou do Movimento da Fábrica com o Sindicato Queixada e as CEBs. Por outro lado, os estudantes de pós-graduação em Arquitetura e Urbanismo contribuíram com conhecimento técnico sobre a legislação urbanística e cartografia, os quais com frequência são utilizados de modo autoritário e sem o conhecimento aprofundado dos códigos e territorialidades citados anteriormente.

A questão da linguagem é algo a ser discutido e construído coletivamente nesses processos. A utilização de “metodologias conscientizadoras” consiste na busca pela apreensão da totalidade da realidade a partir da análise das partes que as constituem, por meio de temas geradores operando na codificação e descodificação de situações (FREIRE, 2018, pp. 134-135). Em uma das aulas, realizada no Cine Teatro Pandora, apresentou-se uma situação hipotética, similar às questões locais, e a atividade centrava-se na atuação dos alunos para representar personagens disputando narrativas e interesses distintos, como integrantes de movimento social por habitação, gestores locais, pesquisadores e técnicos, ultrapassando a visão simplificadora dos processos que constituem a cidade e as tomadas de decisão e instaurando discussões complexas e reflexões críticas.

A escolha da cartografia como instrumento de investigação tem relevância pedagógica e política, pois possibilita a concepção de sentidos e territórios contra hegemônicos (ACSELRAD, 2013). A aprendizagem sobre o território e sua representação, especialmente para a comunidade, possibilita escrever e inscrever no mapa a história contada por seus próprios moradores, a memória que se mantém viva por meio das práticas cotidianas, muitas vezes ocultadas da história e dos mapas oficiais, oprimidas pelos traçados, fluxos e projetos de cidade dominantes, provenientes de um modo de produção capitalista globalizado. A linguagem cartográfica muitas vezes é utilizada como instrumento de dominação. Por essa razão se dá a 
necessidade do instrumento ser reelaborado coletivamente em busca de uma educação e sociedade mais humanas. A desconstrução de tais linguagens e a decorrente elaboração de narrativas contra hegemônicas tem ocorrido através de práticas colaborativas entre universidade e sociedade civil.

A cooperação, o trabalho em grupos, notado nas práticas educativas realizadas no território de Perus pela universidade em parceria com os coletivos culturais e movimentos sociais, revelam-se como propulsoras de processos de conscientização. Para Freire (2018, p. 228): “a co-laboração, como característica da ação dialógica, que não pode dar-se a não ser entre sujeitos, ainda que tenham níveis distintos de função, portanto, de responsabilidade, somente pode realizar-se na comunicação. O diálogo, que é sempre comunicação, funda a colaboração”.

Durante o processo foi possível perceber um aumento da consciência crítica dos universitários a respeito do território, das territorialidades, das distâncias entre as dinâmicas vividas e os discursos lançados hegemonicamente. A experiência mostrou-se reveladora para os estudantes de pós-graduação que não vivenciavam o território no cotidiano e, por vezes, possuíam preconcepções sobre as dinâmicas e as condições de vida estereotipadas da periferia. Nesse contexto, foi possível observar que o território possui múltiplas funções educadoras. Observou-se que os moradores de Perus que participaram do processo colaborativo da disciplina possuíam conhecimento prévio sobre o território, não somente pela prática empreendida no âmbito da ULC, mas como parte das práticas de suas próprias vidas, pautadas em lutas cotidianas para a construção de narrativas e territórios com mais autonomia, representatividade e qualidade.

Além disso, observou-se que novas formas de construção do saber sob um processo colaborativo foram capazes de mobilizar o território a partir de um tema comum e caro aos territórios periféricos: o direito à cidade. Destaco a importância de formas de construção do saber que se pretendem colaborativas, a partir das relações do sujeito com o território e sua percepção, como também o papel pedagógico e político da atuação de coletivos como resistência, a fim de se pensar novas formas de gestão, existência e sobrevivência nas cidades em permanente construção.

Por fim, a práxis educativa realizada no âmbito da ULC, desde 2011, tem contribuído para o empoderamento dos agentes locais na elaboração de narrativas e propostas nas disputas pelo direito à cidade (HARVEY, 2014), na medida em que ampliadas pela linguagem do planejamento urbano e conhecimento sobre as dinâmicas naturais e urbanas que incidem sobre 
o território, gerando encontros, debates e eventos sobre a regulamentação do TICP com novas redes que extrapolam os limites do distrito e tem percorrido diversos locais da cidade de São Paulo. Nesse processo de ir e vir, de mover-se no mundo e compreender-se no mundo tem-se que “a educação problematizadora se faz, assim, um esforço permanente através do qual os homens vão percebendo, criticamente, como estão sendo no mundo com que e em que se acham” (FREIRE, 2018, p. 100).

Figura 89 - Aldeia indígena Guarani no Parque Estadual do Jaraguá. Local onde foi ministrada uma aula da disciplina Territórios de Interesse da Cultura e da Paisagem do programa de pós-graduação da Faculdade de

Arquitetura e Urbanismo da USP, em 2019.
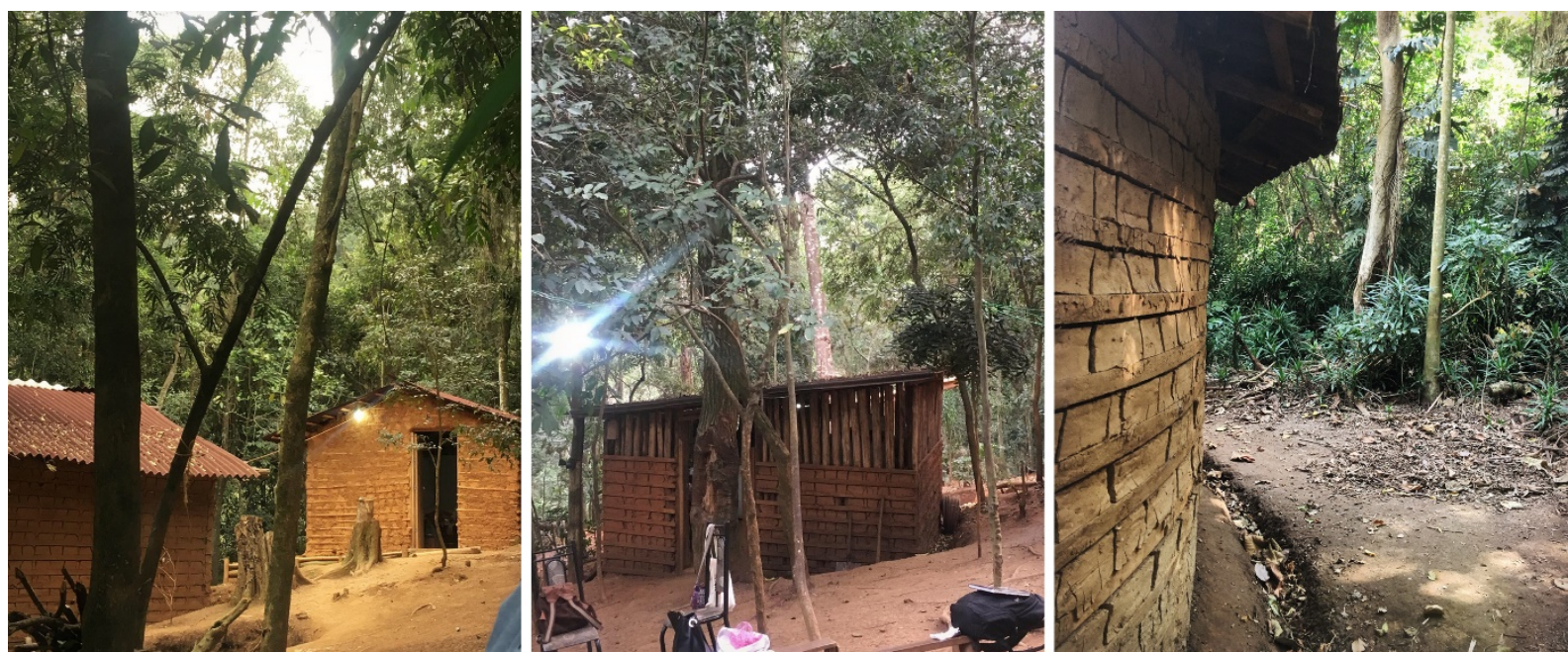

Fonte: acervo pessoal.

Figura 90 - Nuvem de palavras a partir dos relatos dos participantes de Perus

$$
\begin{aligned}
& \text { disciplinas municipal conversa projetos } \\
& \text { movimentos social cursinho acha ação dinheiro } \\
& \text { sendo dissoconceito tiquipe poder política pensando } \\
& \text { menos visãoinclusive pensar rede começou pesquisa centro }{ }^{\text {muita }} \\
& \text { participar ala coletivos meio ainda algumas outros pesquep precisa todas } \\
& \text { atuação professor feito fazendo prande colaborativa partir } \\
& \text { moradores hoje culturalquilombaque minha exemplo recal fica ticp época } \\
& \text { professoresnada falou queria anos quer cidade cultura questões comunidade } \\
& \text { nessoaluniversidade rio livre região ficou existe } \\
& \text { coletivo mundo nossatodo pessoaluniversidade sobre conta muitas }
\end{aligned}
$$

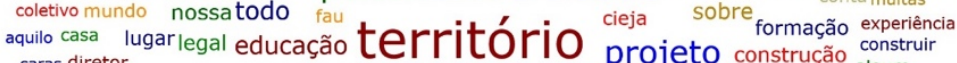

$$
\begin{aligned}
& \text { caras diretor grupo pessoa } \\
& \text { perus anonessa questão alguma alunos ensind } \\
& \text { contato vezes sabe momento pergunta } \\
& \text { junto paisagem conhecimento ideia nunca tinham vida anhanguera } \\
& \text { interesse proposta fábrica forma perspectiva ideia gestãotanto entendeu } \\
& \text { frente mestrado depoismovimento entrarconsegue curso } \\
& \text { primeiro espaço estava ponto entender } \\
& \text { ajudar desenvolverescolas começa população usp consegui } \\
& \text { problemacolocar estudar } \\
& \text { paulista referência arte claro vamos sair várias }
\end{aligned}
$$

Fonte: elaboração da autora, por meio do software ATLAS.ti 9. 
Figura 91 - Ilustração com a representação dos agentes com quem tive maior contato no âmbito da Universidade Livre e Colaborativa e das discussões vinculadas ao território de Perus, como o TICP

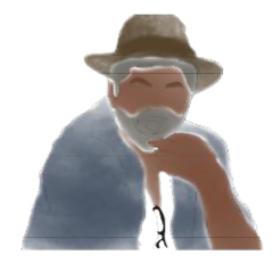

Soró

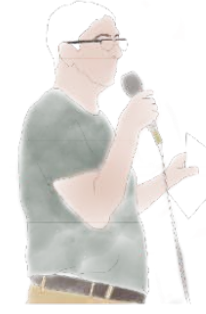

Mario

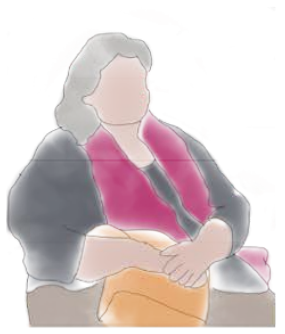

Franciele

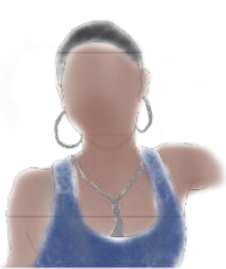

Ananda

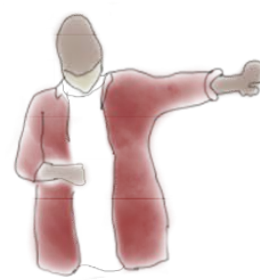

Aluno

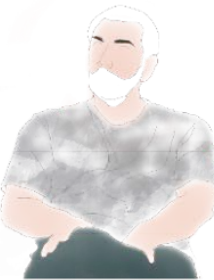

Euler

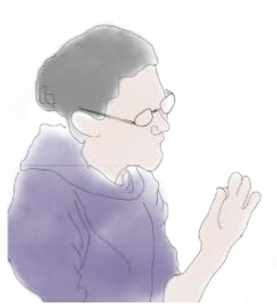

Regina
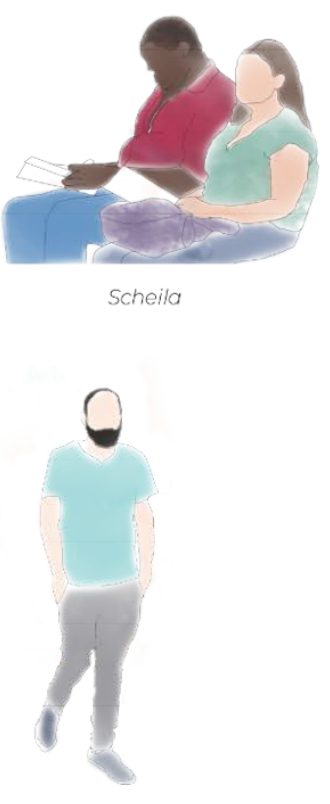

Henrique

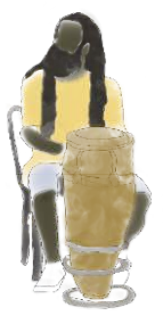

Fofão

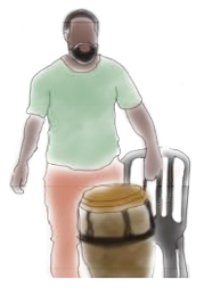

Almir

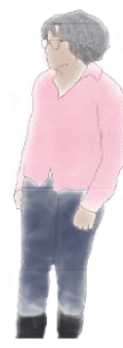

Miriam

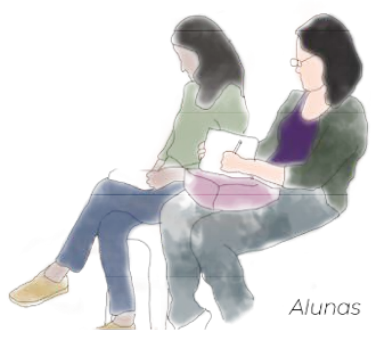

Fonte: idealização da autora, elaboração Camilla Ortega. 


\subsubsection{As práticas educativas em Perus na ótica da educação freireana}

Assim como foi identificado com relação às práticas no Bororé, também em Perus foi possível verificar aspectos da concepção freireana nas práticas educativas constatadas no território. De igual maneira, apresento a análise à luz dos elementos elencados por Gadotti (2012, p. 23) como representativos das “contribuições de Paulo Freire à educação popular, social e comunitária”:

“1. Teorizar a prática para transformá-la. A prática como base para gerar pensamento. Os sujeitos populares como protagonistas do seu próprio aprendizado e atores de sua emancipação” (GADOTTI, 2012, p. 23):

[...] aí na hora a nossa é um Museu Territorial que conta através de trilhas educativas pontos do desenvolvimento do Brasil aonde aconteceu.... Aí os caras chapou nas ideias, aí foi aí que chegou na questão do Museu... E aí a gente vem na questão museológica sobre esse processo que é uma sacada, né, e não existe Museu territorial na cidade de São Paulo [...] que é fazer as ações e sair dessa linha tradicional de museu onde tem um espaço com as peças da época que você não pode nem tocar. O nosso é ao contrário, tá dentro já, o morador, você já mora no museu onde você pode vivenciar e pode contar essa história dentro da onde aconteceu esse território, né. Então vai desde as aldeias, processo de colonização, na mineração, industrialização, da ditadura militar,né, até chegar na questão das ações e movimentos sociais. E aí a gente define a nossa ação como o turismo de resistência, que a gente conta é só luta social do território, onde os livros didáticos não conta...

(PARTICIPANTE 10, entrevista concedida a Analu Garcia, 2020).

Aqui, mais uma vez, verifica-se a utilização de conceitos cotidianos como processo pedagógico de compreensão dos conceitos científicos.

“2. O reconhecimento da legitimidade do saber popular, da cultura do povo, suas crenças, numa época de extremado elitismo (academicismo sem prática social) ” (GADOTTI, 2012, p. 23):

[...] é o seguinte: também não venha querer ser o dono da razão, do notório saber que, meu, aqui não funciona! Aqui a gente tem um conhecimento também, a gente respeita conhecimento da academia porque querendo ou não é que a sociedade reconhece, não o conhecimento do poder popular, dos conhecimentos dos mestres populares e 
conhecimento da Periferia... Não tem qual é o melhor e sim são conhecimentos diferentes que agregam no outro...

$[\ldots]$

“Então... a gente tinha conflito com a Universidade, com os estudantes que ia lá achar que a gente era objeto de estudo e a gente falava "não, o pessoal vem e acha que a periferia não sabe produzir conhecimento, acha que academia tem o notório saber” e a gente aí toda vez que o pessoal vinha e se for para isso a gente não vai querer fazer, a gente quer fazer parceria de trocar conhecimento”.

[...]

A gente conta desde a luta dos indígenas, né, na aldeia e o processo de colonização que teve, o processo de escravidão que aconteceu e isso vai apagado lá no contexto histórico do território e teve a primeira leva de angolanos chegou no nosso território e sumiu... A gente tava fazendo um estudo de um cemitério de escravo ali no pé do lixão e dos quilombos que existiram na região de Pirituba, isso foi apagado da história. E aí você tem que ter muita pesquisa para tentar descobrir alguma coisa, né... Então nessa questão que a gente tenta trazer a luta de preservação do patrimônio material e imaterial.

(PARTICIPANTE 10, entrevista concedida a Analu Garcia, 2020).

Os trechos expostos apresentam a visão dos coletivos a respeito do valor do saber popular e a importância de se reconhecer tais saberes como conhecimento válido, bem como práticas educativas realizadas nesse sentido.

“3. Um método de ensino e pesquisa que parte da leitura da realidade (leitura do mundo), da observação participante. Parte do concreto, o mundo vivido dos sujeitos e setores populares. Ensino-aprendizagem inseparável da pesquisa, da cultura popular e da participação da comunidade” (GADOTTI, 2012, p. 23):

[...] a gente tá fazendo um inventário de referências culturais, fizemos 7 ou 8 oficinas na região do Jaraguá, Anhanguera, Perus, um levantamento pra sistematizar os lugares que tem significado pra comunidade, e agora transformar isso numa cartografia, onde as pessoas do território podem pesquisar com mais assertividade e objetividade os temas do território.

(PARTICIPANTE 6, entrevista concedida a Diego Fernandes, 2019).

Em 2012 a gente já começou a fazer trilha para dentro da fábrica... fazia trilha para explicar o processo da fábrica a gente tinha uma proposta de fazer um desenvolvimento artístico na fábrica onde as pessoas se caracterizavam como 
moradores da época e eles contavam essa história dentro lá do cenário, só que não foi pra frente essa proposta né...

(PARTICIPANTE 10, entrevista concedida a Analu Garcia, 2020).

O primeiro trecho demonstra a utilização da cartografia como metodologia aliada aos elementos da realidade concreta dos sujeitos para ensino-aprendizagem. O segundo, por sua vez, ilustra a metodologia conscientizadora proposta por Freire (2018) por meio da codificação e decodificação da realidade.

“4. Uma teoria crítica do conhecimento, fundamentada numa antropologia (ser humano inacabado, incompleto, inconcluso): somos programados para aprender. Importância das condições de aprendizagem: ênfase nos processos e não nos resultados” (GADOTTI, 2012, p. 23):

É! A gente discute isso.... No caso de Cultura é indissociável, não tem como tirar e a gestão vê a cultura como entretenimento. Não é entretenimento, é parte educacional que traz, né. A gente foge de um sistema arcaico de educação, né, onde as pessoas tem que ir lá assistir aula e se fizer bagunça é expulso do negócio, né... Aí a cultura vem com outro, uma outra forma de educação, educação freiriana, né, que traz as pessoas, independente da sua idade, uma vai se educando a outra, vai trocar, troca de conhecimento, né, intergeracional. É uma discussão muito interessante na composição de educar, por isso que a gente pensa na proposta de um território educador frente a tudo isso, né. É um conjunto educação, cultura, arte, patrimônio, as memórias, os afetos, as relações. Então todos esses componentes geram um território educador. Então por isso que a gente bate muito nessa questão...

(PARTICIPANTE 10, entrevista concedida a Analu Garcia, 2020).

A passagem transcrita demonstra a concepção de educação freireana no sentido de uma educação associada à cultura e como processo contínuo, isto é, que abrange todas as faixas etárias, possibilitando, assim, as trocas intergeracionais de conhecimento.

“5. Uma educação como prática da liberdade, precondição para a vida democrática: educação como produção e não meramente como transmissão de conhecimentos; a educação como ato dialógico (recusa do autoritarismo), ao mesmo tempo rigoroso e imaginativo” (GADOTTI, 2012, p. 23): 
[...] quando o CIEJA, por exemplo, que é um lugar de abandono se levanta e acredita que é possível agir como território educador, isso deixa as escolas chapadas, e muitas delas começam a se mexer, é esse movimento que a gente quer produzir, nosso empenho enquanto Quilombaque e alguns coletivos que estão juntos é construir referências, sempre trabalhar na construção de referência, então por exemplo se a gente pega um serviço conveniado esse serviço vai se tornar referência, ou Centro Cultural ou a biblioteca, ganham essa potência e essa força, a tecnologia social é quando você reaplica essa força em outras realidades e outros lugares, para que não fique uma coisa específica de Perus. Não é você pode modular e implantar em outros lugares, cada alugar tem um processo, mas a lógica de poder é essa, criar um poder fora e esse poder forçar a governança local para o interesse social para melhorar o território, fazer com que as escolas funciona, cada escola é maior B.O. é um absurdo, só tem duas coisas do Estado que chegam perto da população, uma é o estado e outra é a polícia, em cada morro tem uma escola, muitos anos eu escuto que vão abrir a escola em fim de semana, as escolas podem ser polos culturais, podem tem todas as condições pra isso, mas o povo das escolas mata. Você tem um polo cultural a cada $500 \mathrm{~m}$, os caras ficam 6h por dia, $30 \mathrm{~h}$ por semana, durante 8 anos, daria pra fazer muita coisa. Mas as escolas não são democráticas, e não querem, e inclusive é uma treta com a professoraiada, a gente pegou uma escola do morro doce, a escola lá na ponta do morro que nenhum professor queria, só iam pra lá os professores que ficavam por último, os punidos, e desse bando de fracassados que o difícil acesso da escola juntou, eles criaram uma integração impressionante. Pra gente é um ato político declarar apoio a essa escola do morro doce. O mesmo vale para o CIEJA.

(PARTICIPANTE 1, entrevista concedida a Analu Garcia e Diego Fernandes, 2019).

O trecho demonstra a prática de uma educação libertadora, emancipatória e dialógica, em contraposição a uma educação formal antidemocrática, ou na concepção de Freire (2018), de uma educação bancária.

“6. Uma ciência aberta às necessidades populares: a relevância social como critério de qualidade da ciência” (GADOTTI, 2012, p. 23):

Foi aí que a gente fez a proposta da Universidade Livre, que o Euler falou "não, dá para trazer a disciplina para cá e a comunidade participa, os movimentos sociais, os professores, a gente constitui um trabalho de desenvolvimento no território”. A princípio a gente pensou só na questão da Fábrica de Cimento, né...

(PARTICIPANTE 10, entrevista concedida a Analu Garcia, 2020). 
O que é Universidade traz, ela traz embasamento técnico que a gente não tem, esse conhecimento que foi negado para nós, né. [...] Então traz esse embasamento técnico que é necessário para pensar no desenvolvimento territorial, mas o processo de ideia, o que a gente quer alcançar, a galera tem muito claro na mente, nessa perspectiva como pode ser feito... então academia traz essa parte técnica que a gente não tem, né. A gente vem na perspectiva da Sevirologia, né...

(PARTICIPANTE 10, entrevista concedida a Analu Garcia, 2020).

Os trechos demonstram a participação da universidade nas práticas realizadas pelos coletivos, a fim de exercer a sua função social em sintonia com os interesses da comunidade no território de Perus, bem como a importância do conhecimento técnico universitário nesse processo.

“7. Harmonização entre o formal e não-formal. O direito à educação não é apenas direito de ir à escola, mas direito de aprender na escola e ter acesso a oportunidades de educação não formal (cinema, teatro, esporte, cultura, lazer...) ” (GADOTTI, 2012, p. 23):

[...] nós não temos de sala de aula então não tem como manter, mas a gente cede um sábado para isso na parte da manhã e de tarde o dia todo, e as pessoas frequentam o dia inteiro de cursinho porque se a gente cedesse a semana a gente tem outras atividades e não ia, né, não ia dar certo essa relação, porque a gente tem ensaio de percussão, como que cê vai estudar com percussão? A gente incorpora as atividades, chama o CIEJA [...] então a gente faz, abre a roda e chama alguém pra fazer formação que interessa, cinema que tem uma discussão também. O CIEJA sempre participa conosco, né. O roda de baobá, que é estudo de leitura de algum autor que a gente também faz. Então sempre tá recebendo essas pessoas, escolas recebem, as escolas também frequenta e a gente compõe a parte educacional assim, né, de formação em roda e sem essa sala de aula aí meio quadrada um atrás do outro...

(PARTICIPANTE 10, entrevista concedida a Analu Garcia, 2020).

Esta passagem ilustra a realização de práticas educacionais não formais e sua importância na complementação do ensino tradicional para a formação do indivíduo.

“8. A utopia como verdadeiro realismo do educador, opondo-se ao fatalismo neoliberal que nega o sonho de outro mundo possível” (GADOTTI, 2012, p. 23): 
É possível você organizar o território do ponto de vista do movimento cultural das periferias, é um plano de poder que a gente traçou, governança local, qual que é a nossa crença, que você constitui redes fortes você cria integração local, por que a prefeitura não vai fazer a integração, não vai rolar, sei lá, o CRAS e a educação, não rola, então o que a gente decidiu, construir um poder a partir de fora, e esse poder forçar os caras a se integrarem, mas a gente tem uma governança e essa pressão vai fazer com que eles se mexam.

(PARTICIPANTE 1, entrevista concedida a Analu Garcia e Diego Fernandes, 2019).

O desinteresse do poder público em atender às demandas populares apontado no trecho acima é a marca de um governo neoliberal. Neste contexto, a passagem transcrita apresenta a solução encontrada pelos coletivos territorializados para o enfrentamento do problema.

“9. A educação como direito humano, direito de se emancipar, combinando trabalho intelectual com trabalho manual, reflexão e ação, teoria e prática, conscientização e transformação, a organização, o trabalho e a renda (economia popular solidária)” (GADOTTI, 2012, p. 23):

Então pensa no desenvolvimento territorial, então é essa perspectiva de investimento e de descentralização desse orçamento. Então o coletivo pega não é só na questão cultural mas sim tem a parte das costureiras, tem, né, o cenário... Então já é uma economia gerada ali para nossa região... Então a nossa ação com o museu também é nessa perspectiva de desenvolvimento sustentável local... tirar recurso dentro do bairro e não o bairro saí do seu território e ir pro Centro para gerar renda e essa renda lá. Tem que trazer dinheiro para desenvolver o nosso território [...] Na perspectiva que a gente tem é desenvolver através da memória, da preservação da nossa região porque o TICP é um instrumento muito importante para gente fazer enfrentamento para especulação Imobiliária.

$[\ldots]$

E aí a gente tem esse desenvolvimento nessa perspectiva de gerar renda para dentro dos bairros e os bairros ter esse desenvolvimento que não seja das pessoas acordar cedo, pegar o trem para o centro atrás de subemprego e sim morar e trabalhar na mesma região, já garante, meu, uns 10 anos de vida de pegar transporte público...

(PARTICIPANTE 10, entrevista concedida a Analu Garcia, 2020).

Os trechos apresentam as práticas educativas realizadas pelos coletivos de cultura em uma dimensão voltada ao desenvolvimento local sustentável, a fim de garantir aos indivíduos 
do território direitos humanos básicos, como moradia, transporte, trabalho, alimentação, segurança etc.

Portanto, assim como no território do Bororé, foi possível verificar que as práticas educativas em Perus podem ser classificadas como práticas de educação popular na concepção de Paulo Freire. Destaco novamente que tal verificação se deu por meio da análise do material coletado em campo. 


\section{CONSIDERAÇÕES FINAIS}

O território é um termo polissêmico que apresenta diversas utilizações tanto no campo do ativismo social como dentro da academia, em diversas áreas do conhecimento. Trata-se de um conceito central na Geografia, que, em razão de sua importância, passou a ser utilizado também no campo da Arquitetura e Urbanismo, tendo em vista que responde a uma necessidade da área de compreender o espaço urbano diante de suas complexidades contemporâneas.

Dentre a pluralidade de conceitos, optei pela definição de Raffestin, no sentido de que o território compreende não apenas o espaço físico, mas sim no produto deste com as relações sociais. No âmbito do ativismo, o termo é geralmente carregado da noção de relação entre sujeito e espaço, o que envolve uma dimensão cultural, política e relações de poder, conforme concepção de Raffestin (1993). A partir dessa concepção, procurei abordar as contradições e “relações dissimétricas” existentes entre os territórios da “cidade formal e informal”, como um processo histórico que leva os grupos marginalizados a se organizarem como territórios de resistência. Tais mobilizações deixaram marcas nesses territórios e produziram memórias de luta até hoje vivas nos discursos e práticas dos sujeitos. Neste contexto, a educação atua como instrumento de conscientização política que leva à mobilização em busca de transformações sociais.

Assim, procurei investigar, dentro do campo da educação, de que maneira os discursos pedagógicos passaram a considerar a cidade como território educativo, para além da educação tradicional oferecida pela escola. A investigação a respeito do desenvolvimento da educação teve como delimitação o século XX, período no qual foi elaborada uma linha histórica. Busquei destacar a importância do movimento da Escola Nova na busca de uma renovação da pedagogia ao contexto da época, isto é, a uma sociedade em processo de modernização e urbanização, em oposição a uma escola tradicional, elitista e fechada em si mesma. Para tanto, a Escola Nova defendia a "educação como experiência” que demanda contato com a concretude do cotidiano. Outra contribuição importante que identifiquei por meio da pesquisa teórica consiste na abordagem de Vygotsky, no início do século XX, a respeito do desenvolvimento cognitivo do ser humano. Suas considerações foram inovadoras para a época e continuam servindo como referência no campo da educação. Ademais, sua abordagem do desenvolvimento do ser humano mediado pelas relações socioculturais se alinham à concepção de Paulo Freire.

Os contextos de ruptura ocorridos na década de 1960 e seus reflexos nas ciências do urbano e na educação também foram de suma importância para compreender discursos e 
práticas da atualidade. Desse modo, foi apresentado o contexto em que a crítica à escola formal emerge, notadamente diante da escolarização de massas, ensejando o surgimento de propostas alternativas de educação. Para melhor compreender tais propostas, explorei variadas classificações a respeito da educação, como a educação formal, não-formal, informal, popular, comunitária e social, destacando a concepção de educação dialógica e democrática de Paulo Freire.

O início da década de 1990 apresentou um contexto de aprofundamento do neoliberalismo, o que resultou em crises em diversas instâncias. Neste sentido, Boaventura identifica uma crise na universidade pública e a importância de sua renovação, bem como da extensão universitária nesse processo. O receio demonstrado por Boaventura na década de 1990, em certa medida, já era antecipado décadas antes pelos ensinamentos de Paulo Freire acerca do risco de se realizar uma extensão universitária impositiva, em detrimento de um processo dialógico entre o conhecimento técnico, científico e o saber popular.

Na década de 1990 também despontam as noções de “cidade educadora” e "território educador” na Espanha. É importante lembrar que os discursos e práticas, mesmo no âmbito da defesa da cidadania e da educação, não escapam às suas contradições internas e externas, como parte do sistema capitalista globalizado em que estão inseridos. Desse modo, compreendo que o território “educador”, ou “educativo”, existe por meio da "práxis” dos sujeitos, em que os componentes espaciais, relacionais e multidimensionais estejam inseridos em um processo de “conscientização”, por meio do diálogo entre os sujeitos.

Além do esforço teórico em dialogar com as áreas da geografia e da educação, a pesquisa de campo buscou efetivar-se sob uma perspectiva participativa, pela escuta, pelo diálogo. A abordagem cartográfica ao longo dos processos operou como um método de investigação da realidade e de discussão do território em suas diversas camadas com os participantes. A cartografia também foi percebida como uma construção social e um instrumento de poder, com aspecto importante em ambas as experiências na construção de contra-narrativas.

A partir dessa visão possibilitada pelo levantamento teórico e da experiência nas práticas que ocorreram por meio da parceria entre a universidade pública e coletivos territorializados, foram analisadas as práticas educativas realizadas no território do Bororé, por meio da Casa Ecoativa, escola Adrião Bernardes e da extensão universitária do GeMAP FAU/USP, bem como no território de Perus, através da atuação Comunidade Cultural Quilombaque e da Universidade Livre Colaborativa. A análise foi realizada à luz da sistematização feita por 
Gadotti (2012) acerca o pensamento de Paulo Freire, incidindo sobre o exame de uma série de entrevistas realizadas com os agentes envolvidos nos projetos e da própria percepção decorrente do contato com as práticas. A partir da análise foi possível constatar o alinhamento dessas práticas à concepção freireana.

A universidade tem exercido nos últimos anos a reflexão destacada por Boaventura (2005) e buscado incrementar as práticas de extensão universitária como forma de cumprir o seu papel social, processo imprescindível na reconquista de uma legitimidade contestada pelas crises experimentadas nos últimos anos e, mais recentemente, em decorrência dos ataques realizados por setores conservadores da sociedade. Ademais, as práticas de extensão se revelam essenciais para o intercâmbio de conhecimento entre a comunidade e a universidade, bem como para a própria formação do universitário. No campo do urbanismo, diversos são os trabalhos realizados na busca de melhores condições na habitação, na mobilidade e no planejamento urbano, por exemplo.

No presente trabalho foram identificadas contribuições relevantes da universidade, através do GeMAP FAU/USP, nos movimentos realizados pelos coletivos de cultura no Bororé, por meio das atividades de cartografia, workshops com universidades estrangeiras, elaboração de um projeto comum de médio a longo prazo, como o "Bororé ao Mundo”, bem como do reconhecimento manifestado por integrantes do projeto de que a aproximação da universidade resultou em uma maior visibilidade ao local, despertando o interesse de outras entidades a respeito do território e de seus potenciais. Em Perus, a universidade desempenhou, por meio do NEP/USP, papel fundamental na mediação com o Poder Público a respeito da ameaça de remoção sofrida pela Quilombaque, bem como na aprovação do TICP, instrumento urbanístico inserido no Plano Diretor que contempla diretamente a região de Perus, além da colaboração com conhecimentos técnicos, conforme ressaltado por integrantes do projeto. As práticas analisadas demonstram uma postura dialógica por parte da universidade, alinhadas com os princípios da educação e extensão na concepção freireana.

Os coletivos de cultura, por sua vez, vivenciam o território e os desafios constantes do cotidiano na busca por melhores condições de vida, desenvolvimento local e de valorização de uma “identidade periférica”, conforme apontado por Tiarajú D’Andrea (2020), latente e potente. Para tanto, têm realizado também há bastante tempo trabalhos de conscientização a partir de linguagens criativas, diversificadas e inovadoras, que cativam a juventude justamente por trabalharem os aspectos da subjetividade e da formação da identidade. As práticas analisadas neste trabalho demonstram um alto nível de maturidade e um forte alinhamento 
desses agentes à concepção de educação popular de Paulo Freire, com raízes em processos históricos de conscientização política ligadas às lutas urbanas dos anos 1970 e 1980.

Destaco a importância desse tipo de projeto construído em parceria em busca da ampliação de diálogos entre a universidade e a sociedade. Para além da sistematização e do “produto” final dessa análise, que não se pretende conclusiva, mas sim um ponto de partida para um olhar sensível aos processos coletivos e individuais de cada grupo - universidade e coletivos - considero de suma importância o processo como o maior aprendizado para todos os envolvidos. Um processo de educação social, no sentido amplo defendido por Gadotti (2012), na medida em que os processos dialógicos demandam a escuta de outros agentes, a reelaboração simbólica sobre imaginários “dados” e a construção de projetos em comum, desejados e construídos colaborativamente.

Em uma escala mais individual, de "sujeito" da pesquisa e de quem buscou integrar um olhar da universidade com o do território, o processo de (des-re)territorialização durante um ano e meio de trabalho foi essencial para compreender códigos, valores, símbolos, processos, tempos e espaços próprios de cada um desses territórios. Em vista disso, foi possível observar os efeitos que a reconstrução de imaginários promoveu sobre o “fazer e pensar cidade”, a partir de um duplo processo observado tanto nos territórios quanto na minha (re)construção como pesquisadora.

A atuação pedagógica e política desses coletivos, em parceria com projetos de extensão universitária de concepção e prática freireanas, opera como um instrumento potente para serem pensadas e construídas novas formas de gestão, existência e sobrevivência nas cidades que vão se constituir nas próximas décadas, em oposição ao cenário neoliberal cada vez mais sombrio em que estamos inseridos atualmente. $\mathrm{O}$ atual momento político nos alerta para a importância do diálogo contínuo e da união de forças dos setores democráticos da sociedade.

Por fim, vale ressaltar que esta dissertação de mestrado se limitou a compreender as relações entre território, educação e formação cidadã, por meio das práticas educativas dos grupos envolvidos e de um olhar teórico e sistematizado sobre cada território e seus agentes. Para pesquisas futuras, temas importantes que se relacionem com "território e educação" poderão ser aprofundados como: interseccionalidade, cultura afro-brasileira, cultura indígena, pedagogias “periféricas”, linguagens criativas e juventude, linguagem cartográfica e a educação escolar. 


\section{REFERÊNCIAS BIBLIOGRÁFICAS}

ACSELRAD, H.; VIÉGAS, R. N. "Cartografias sociais e território - um diálogo latinoamericano”. In. ACSELRAD, H. (org.) Cartografia social, terra e território. Rio de Janeiro: IPPUR/UFRJ: Coleção Território, Ambiente e Conflitos Sociais, 2013.

AGAMBEN, G. O que é o contemporâneo? e outros ensaios. Tradução Vinícius Nicastro Honesko - Chapecó: Argos, 2009.

AICE. “Carta das Cidades Educadoras - Declaração de Barcelona”. Associação Internacional das Cidades Educadoras, Barcelona, 1994.

ARANTES, O.; VAINER, C.; MARICATO, E. A cidade do pensamento único: desmanchando consensos [2000]. Petrópolis, RJ: Vozes, 2000.

AZEVEDO, R. S. et al. "Os impactos das práticas em espaços não formais na formação docente para o ensino de ciências". In: Anais VIII Simpósio de Educação em Ciências na Amazônia/SECAM | 3 A 5/10/2018.

BASSANI, J. “Das intervenções artísticas à ação política urbana”. São Paulo, 2019. 280 p. Tese (Livre-Docência) - Faculdade de Arquitetura e Urbanismo da Universidade de São Paulo. Departamento de História da Arquitetura e Estética do Projeto.

FAUUSP, 2012.

(org.). PDP: Mapografias: IV Workshop Internacional RED_PUC. - São Paulo:

. Zona Leste de São Paulo: território e territorialização. In: PINTO, P. T. Arqueologias hídricas, na procura da metrópole fluvial. Casal de Cambra, Portugal: Caleidoscópio, 2015. pp. 23-32.

BASSANI, J.; MASSIMETI, F. T.; RODRIGUES, M. "Extensão universitária na Ilha do Bororé: o território como instrumento pedagógico”. In: Anais XVIII ENANPUR, 2019. Disponível em: http://anpur.org.br/xviiienanpur/anais. Acesso em: 20 out. 2019.

. "Mapear o território - Prática e crítica". In: XIV ALEUP (Congreso de la Asociación Latinoamericana de Escuelas de Urbanismo y Planificación), 22 a 24 de Agosto de 2018.

BARTHES, A.; CHAMPOLLION, P. Territories and education for sustainable development. 9th International conference of territorial intelligence, ENTI.17-19 nov. 2010, nov. 2010, Strasbourg, France.

BEZERRA, M. A. M.; BEZERRA, M. H. B., SANTOS, M. M. "Cultura: a escola e os movimentos sociais de Perus”. In: XVIII ENDIPE, Didática e Prática de Ensino no contexto 
político contemporâneo: cenas da Educação Brasileira, 2016. Disponível em: https://www.ufmt.br/endipe2016/downloads/233_10123_36492.pdf. Acesso em: 15 jan. 2020.

BONDUKI, N; FERRON, F. M.; ALVES, T. “Cultura: uma São Paulo para brincar - com o olhar para a criança, uma cidade que pode ser melhor para todos”. In: HADDAD, A. E. São Paulo Carinhosa: o que grandes cidades e políticas intersetoriais podem fazer pela primeira infância. - São Paulo: Secretaria Municipal de Cultura, 2016. pp. 384-401.

BORGES, A. "Cidadania, cultura e território: as práticas educativas dos coletivos de cultura em parceria com a universidade nas bordas da cidade de São Paulo”. In: Seminario Internacional de Investigación en Urbanismo. "XII Seminario Internacional de Investigación en Urbanismo, Sao Paulo/Lisboa, Dezembro de 2020". Barcelona: DUOT, 2020. ISSN 26047756). No prelo (Março de 2021).

BORTOTO, R. C.; BEZERRA, M. H. B. "Fábrica de Cimento Portland Perus: articulação pedagógica entre movimentos populares e escolas no bairro de Perus”. In: Rev. CPC, São Paulo, n.27 especial, pp.185-210, jan./jul. 2019.

BOZOLÃO, I. S.; BORTOTO, R. C. S.; SOUZA, S. B. "Parceria entre a universidade livre e colaborativa e a escola no trabalho de TCA”. In: XVIII ENDIPE, Didática e Prática de Ensino no contexto político contemporâneo: cenas da Educação Brasileira, 2016. Disponível em: https://www.ufmt.br/endipe2016/downloads/233_10123_36492.pdf. Acesso em: 15 jan. 2020.

BRANDÃO, C. R. O que é educação popular. São Paulo: Brasiliense, 2006 (disponível em: https://apartilhadavida.com.br/book/o-que-e-educacao-popular/, acessado em 04 de dezembro de 2020).

BRANDÃO, C. R.; BORGES, M. C. “A pesquisa participante: um momento da educação popular”. In: Rev. Ed. Popular, Uberlândia, v. 6, p.51-62. jan./dez. 2007. Acesso em: 26 maio 2020.

BRITO, G.; PATERNOSTRO, P.; RAIMUNDO, S. L. "Movimento cultural das periferias: compartilhando a caminhada”. Boletim do Observatório da Diversidade Cultural. p.38-43, V.86, n.06, nov./dez. 2019. Edição especial, ISSN 2526-7442

BRITTO, F. D. “A extensão universitária em tempos de crise”. In: D’OTTAVIANO, C.; ROVATI, J. (orgs.). Para além da sala de aula: extensão universitária e planejamento urbano e regional. São Paulo: FAUUSP/ANPUR, 2017, pp. 26-35.

CACCIARI, M. A Cidade. 4. ed - tradução José J. C. Serra. Barcelona: Gustavo Gili, 2010.

CAMPOS, D. M. G. de. "Potencialidades para criação do Território de Interesse da Cultura e da Paisagem (TICP) Jacú-Pêssego na zona leste da cidade de São Paulo”. São Paulo, 2017. f.162. Dissertação (Mestrado em Ciência Ambiental) - Programa de Pós-Graduação em Ciência Ambiental - Instituto de Energia e Ambiente da Universidade de São Paulo. 
CASCAIS, M. G. A.; TERÁN, A. F. "Educação formal, informal e não formal em ciências: contribuições dos diversos espaços educativos". In: XX Encontro de Pesquisa Educacional Norte Nordeste (XX EPENN), realizado pela Universidade Federal do Amazonas-UFAM de 23 a 36 de agosto de 2011, Manaus-AM. Disponível em: https://ensinodeciencia.webnode.com.br. Acesso em: 10 jan. 2020.

CASTELLAR, S. M. V. "Espaços não formais de aprendizagem e a interdisciplinaridade na prática docente da escola pública: o zoológico e o planetário”. In: VIII Congreso Internacional sobre Investigación en la Didáctica de las Ciencias. p. 3381-3385, 2009. Disponível em: http://ice.uab.cat/congresos2009/ eprints/cdcongres/proposteshtm/propostes/art-3381-3385.pdf. Acesso em: 09 jan. 2020.

CASTELLAR, S. M. V. “A superação dos limites para uma educação geográfica significativa: um estudo sobre a e na cidade”. In: Revista Geográfica de América Central, Número Especial EGAL, 2011- Costa Rica II Semestre 2011 pp. 1-25.

. "Cartografia escolar e o pensamento espacial fortalecendo o conhecimento geográfico”. In: Revista Brasileira de Educação em Geografia, Campinas, v. 7, n. 13, p. 207 232, jan./jun., 2017.

. Educação geográfica: a psicogenética e o conhecimento escolar. In: Cad. Cedes, Campinas, vol. 25, n. 66, p. 209-225, maio/ago. 2005. Disponível em: http://www.cedes.unicamp.br. Acesso em: 10 jan. 2020.

"Mudanças na prática docente: espaços não formais e o uso da linguagem

cartográfica”. Disponível em: http://observatoriogeograficoamericalatina.org.mx/egal12/Ensenanzadelageografia/Investigaci onydesarrolloeducativo/15.pdf. Acesso em: 10 jan. 2020.

CASTELLAR, S. M. V.; JULIASZ, P. C. S. "Educação geográfica e pensamento espacial: conceitos e representações”. In: ACTA Geográfica, Boa Vista, Edição Especial 2017. pp.160178.

CAVALCANTI, L. S. Geografia, escola e construção de conhecimentos. Campinas: Papirus, 1998.

CAVALIERE, A. M. V. “Educação integral: uma nova identidade para a escola brasileira?” In: Revista Educação \& Sociedade, Campinas, vol. 23, n. 81, p. 247-270, dez. 2002. Disponível em: http://www.cedes.unicamp.br. Acesso em: 10 fev. 2020

CHAMPOLLION, P. "Education and territory: a conceptual framework". In: Journal of education, vol. 3, Issue 2, pp. 12-27, 2015.

CHAUÍ, M. Cidadania cultural. - 1. ed. - São Paulo: Editora Fundação Perseu Abramo, 2006. 
COLLET-SABÉ, J. Relaciones entre Universidad y Ciudad: de la "gobernanza instrumental mutua" a la "gobernanza del bien común". (Articulo basado en el informe "Per unes noves relacions entre ciutat i universitats: comunitzar la universitat i el coneixement, comunitzar la ciutat” realizado para la ACUP - Asociación Catalana de Universidades Públicas). Disponível em: https://universityofvic.academia.edu/ColletSab\%C3\%A9Jordi. Acesso em: 10 set. 2019.

COLLET-SABÉ, J.; SUBIRATS, J. H. "Educación y territorio: 15 años de Proyectos Educativos de Ciudad (PEC) en Cataluña (España). Análisis, evaluación y perspectivas”. In: Scripta Nova. Revista Electrónica de Geografía y Ciencias Sociales. [En línea]. Barcelona: Universidad de Barcelona, 15 de marzo de 2016, vol. XIX, nº 532.

. “El `descubrimiento` del entorno: Una educación socialmente contextualizada”. In: Cuadernos de pedagogía, ISSN 0210-0630, Nº 375, 2008 (Ejemplar dedicado a: Planes educativos de entorno), p. 54-56.

COOMBS, P. H. The world educational crisis. Nova York: Oxford University Press, 1968.

COOMBS, P.; AHMED, M. Attacking rural poverty: how nonformal education can help (English). A World Bank research publication. Baltimore MD; The Johns Hopkins University Press, $1975 . \quad$ Disponível em: http://documents.worldbank.org/curated/en/656871468326130937/Attacking-rural-povertyhow-nonformal-education-can-help. Acesso em: 14 fev. 2020.

CRUZ, M. P. Interação museu-escola: uma análise da contribuição do ensino não-formal à escola. [Rio de Janeiro] 200874 p. 29,7 cm (Mestrado Profissional em Ensino de Ciências da Saúde e do Ambiente/IFRJ, M.Sc., Ensino, 2008). Dissertação - Instituto Federal de Educação, Ciência e Tecnologia do Rio de Janeiro, PROPEC.

D’ANDREA, T. P. “A formação dos sujeitos periféricos: cultura e política na periferia de São Paulo”, 2013. 309 f. Tese (Doutorado em Sociologia) - Programa de Pós-Graduação em Sociologia - Faculdade de Filosofia, Letras e Ciências Humanas da Universidade de São Paulo,, 2019.

D’ANDREA, T. "Contribuições para a definição dos conceitos periferias e sujeitas e sujeitos periféricos”. Novos Estudos, Cebrap, vol. 39, jan-abr/2020, pp. 19-36.

D’OTTAVIANO, M. C. L.; ROVATI, J. (orgs.) Além dos muros da universidade: planejamento urbano e regional e extensão universitária. São Paulo: FAUUSP, 2019.

D’OtTAViAnO, M. C. L.; ROVATI, J. (orgs.) Para além da sala de aula: extensão universitária e planejamento urbano e regional. São Paulo: FAUUSP, 2017.

DAMASCENO, M. N.; BESERRA, B. “Estudos sobre educação rural no Brasil: estado da arte e perspectivas”. In: Educação e Pesquisa, São Paulo, v.30, n.1, p. 73-89, jan./abr. 2004. 
DARROZ, L. M. “Aprendizagem significativa: a teoria de David Ausubel”. In: Espaço Pedagógico, v. 25, n. 2, Passo Fundo, p. 577-580, maio/ago. 2018. Disponível em: www.upf.br/seer/index.php/rep. Acesso em: 11 fev. 2020.

DEÁK, C.; SCHIFFER, S. R. (org.). O processo de urbanização no Brasil. São Paulo: EdUSP, 1999.

DEBORD, G. A sociedade do espetáculo. São Paulo: eBooksBrasil.com, 2003. Versão eletrônica produzida pelo Coletivo Periferia. Disponível em: $<$ http://www.geocities.com/projetoperiferia>. Acesso em: 03 set. 2019.

DELORS, J. et al. Learning: the treasure within. UNESCO: Paris, 1996.

DIPUTACIÓN DE BARCELONA. Los proyectos educativos de ciudad (PEC): Análisis de la experiencia acumulada Nueva propuesta metodológica. Barcelona: Gam, 2005. (Colección Guías Metodológicas)

FARIA, A. B. G. “Outros sujeitos, outros territórios: em busca do território educativo, integral e integrador”. In: HADDAD, A. E. São Paulo Carinhosa: o que grandes cidades e políticas intersetoriais podem fazer pela primeira infância. - São Paulo: Secretaria Municipal de Cultura, 2016. pp. 526-540.

FAURE, E. et al. Aprender a ser: la educación del futuro. Versión española de Carmen Paredes de Castro. Alianza/UNESCO: Madrid, 1973.

FILHO, M. C. “A educação rural concebida por organismos internacionais e suas repercussões no Brasil nas décadas de 1960 e 1970”. In: Revista Brasileira de Educação, v. 24, e240055, 2019.

FRANCO, F. M.; HERLING, T. “A Política de Desenvolvimento Urbano e o Território CEU”. In: HADDAD, A. E. (org.). São Paulo Carinhosa: o que grandes cidades e políticas intersetoriais podem fazer pela primeira infância. - São Paulo: Secretaria Municipal de Cultura, 2016. pp. 372-383.

FREIRE, P. Ação cultural para a liberdade. 5. ed. - Rio de Janeiro: Paz e Terra, 1981.

Conscientização: teoria e prática da libertação: uma introdução ao pensamento de Paulo Freire. Tradução de Kátia de Mello e Silva; revisão técnica de Benedito Eliseu Leite Cintra. - São Paulo: Cortez \& Moraes, 1979.

. Extensão ou comunicação? Tradução de Rosica Darcy de Oliveira, prefácio de Jacques Chonchol. - 7. ed. - Rio de Janeiro, Paz e Terra, 1983.

Pedagogia da autonomia: saberes necessários à pratica educativa. [1996] - 25 ed. - São Paulo: Paz e Terra, Coleção Leitura, 2002. 
. Pedagogia do Oprimido. - 66. ed. - Rio de Janeiro/São Paulo: Paz e Terra, 2018.

GADOTTI, M. "Educação popular, educação social, educação comunitária: Conceitos e práticas diversas, cimentadas por uma causa comum”. Revista Diálogos: pesquisa em extensão universitária. In: IV Congresso Internacional de Pedagogia Social: domínio epistemológico. Brasília, p. 10-32, v.18, n.1, dez, 2012.

. "Escola cidadã, cidade educadora: projetos e práticas em processo. In: Notícias: Fórum Mundial de Educação São Paulo”. Revista Pós. n. 14, dez. 2003. pp. 130-139. Disponível em: https://www.revistas.usp.br/posfau/article/view/43364/46986 . Acesso em: 24 jan. 2020.

“Extensão Universitária: Para quê?”, 2017. Disponível em: https://www.paulofreire.org/images/pdfs/Extensão_Universitária__Moacir_Gadotti_fevereiro_2017.pdf

"Povo soberano, povo que educa". In: PADILHA, P. R.; CECCON, S.; RAMALHO, P. (orgs.). Município que educa: múltiplos olhares. - São Paulo: Editora e Livraria Instituto Paulo Freire, 2010.

GHANEM, E. "Educação formal e não-formal: do sistema escolar ao sistema educacional”. In: TRILLA, J.; GHANEM, E.; ARANTES, V. A. (org). Educação formal, não-formal: pontos e contrapontos. - São Paulo: Summus, 2008. - (Coleção pontos e contrapontos)

GIRARDI, E. P. “A construção de uma cartografia geográfica crítica.” In: Revista Geográfica de América Central, Número Especial EGAL, 2011- Costa Rica II Semestre 2011. pp. 1-17.

GIROTTO, E. “A geografia importa: análise da dimensão espacial de duas políticas educacionais no estado de São Paulo, Brasil”. Revista da Associação Nacional de Pósgraduação e Pesquisa em Geografia (Anpege). p.158-190, V.14, n.23, jan./abr. 2018.

GOHN, M. G. "Educação não-formal, educador (a) social e projetos sociais de inclusão social”. Meta: Avaliação, Rio de Janeiro, v. 1, n. 1, p. 28-43, jan./abr, 2009a.

. "Educação, trabalho e lutas sociais”. In: GOHN, Maria da Glória. A cidadania negada: políticas de exclusão na educação e no trabalho. Buenos Aires: CLACSO, 2000. Disponível em: http://bibliotecavirtual.clacso.org.ar/clacso/gt/20101010022427/6gohn.pdf. Acesso em: 25 jan. 2020.

. “Movimentos sociais na contemporaneidade”. Revista Brasileira de Educação. v. 16 n. 47 maio-ago. 2011.

. "Paulo Freire e a formação de sujeitos sociopolíticos”. Cadernos de Pesquisa: Pensamento Educacional, v. 4, n. 8, jul. - dez, 2009b. Disponível em: https://seer.utp.br/index.php/a/article/view/1887. Acesso em: 10 jan. 2020. 
GROSFOGUEL, R. "Para descolonizar os estudos de economia política e os estudos póscoloniais: Transmodernidade, pensamento de fronteira e colonialidade global”. In: SANTOS, B. S.; MENESES, M. P. (Orgs.). Epistemologias do Sul. Coimbra: Edições Almedina, 2009, p. 383-418.

HADDAD, A. E. "Política Municipal São Paulo Carinhosa: o que as grandes cidades e as políticas intersetoriais podem fazer por suas crianças”. In: HADDAD, A. E. São Paulo Carinhosa: o que grandes cidades e políticas intersetoriais podem fazer pela primeira infância. - São Paulo: Secretaria Municipal de Cultura, 2016. pp. 198-209.

. "São Paulo Carinhosa: política municipal para a primeira infância - origem e caminho percorrido (Introdução)”. In: HADDAD, A. E. São Paulo Carinhosa: o que grandes cidades e políticas intersetoriais podem fazer pela primeira infância. - São Paulo: Secretaria Municipal de Cultura, 2016. pp. 18-23.

HADDAD, A. E.; ALVES, T.; BARTOS, M. S. H.; COSTA, et al. A escuta e o olhar as crianças para orientar a requalificação do espaço urbano: a experiência em um território do Glicério. In: HADDAD, A. E. São Paulo Carinhosa: o que grandes cidades e políticas intersetoriais podem fazer pela primeira infância. - São Paulo: Secretaria Municipal de Cultura, 2016. pp. 422-427.

HAESBAERT, R. O mito da desterritorialização: do "fim dos territórios" à multiterritorialidade [2004]. - 11. ed. - Rio de Janeiro: Bertrand, 2019.

HAN, B. C. Sociedade do cansaço. Tradução de Enio Paulo Giachini. 2. ed. ampliada Petrópolis, RJ: Editora Vozes, 2017.

HARLEY, J. B. Deconstructing the map. Evanston, I L: Program of African Studies, Northwestern University, $\mathrm{n}^{\circ}$. 3, pp. 10-13, 1992. (Reprinted from Cartographica, v. 26, n. 2 (Spring 1989), 1-20) Disponível em: http://hdl.handle.net/2027/spo.4761530.0003.008. Acesso em: 05 jun. 2019.

HARVEY, D. Cidades Rebeldes: do direito à cidade à revolução urbana. Tradução Jeferson Camargo. - São Paulo: Martins Fontes, 2014.

"Do administrativismo ao empreendedorismo: a transformação da governança urbana no capitalismo tardio”. In. HARVEY, D. A produção capitalista do espaço. São Paulo: Annablume, 2005, pp. 163-190.

HOLSTON, J. Cidadania insurgente: disjunções da democracia e da modernidade no Brasil. Tradução Claudio Carina; revisão técnica Luísa Valentini. - 1. ed. - São Paulo: Companhia das Letras, 2013.

LEFEBVRE, H. Henri Lefebvre e a Internacional Situacionista. Entrevistador: Kristen Ross. Entrevista de 1983 por ROSS, Kristen, 1983. Disponível em: <http://guydebord.blogspot.com.br/2009/06/henri-lefebre.html>. Acesso em: 20 ago. 2019. 
O direito à cidade. Tradução Cristina C. Oliveira. Itapevi, SP: Nebli, 2016.

LIMA, P. F. “A paisagem como ferramenta de conservação ambiental na EMEF Prof ${ }^{a}$ Marili Dias”. In: XVIII ENDIPE, Didática e Prática de Ensino no contexto político contemporâneo: cenas da Educação Brasileira, 2016. Disponível em: https://www.ufmt.br/endipe2016/downloads/233_10123_36492.pdf. Acesso em: 15 jan. 2020.

MAGNOLI, Demétrio. O grande jogo. Política, cultura e ideias em tempo de barbárie. São Paulo: Ediouro, 2006. Introdução e Capítulo 1: Heranças da Guerra Fria pp.11-35

MAIA, H. C. A. et al. "Geografia, infância e ludicidade: um diálogo sobre a construção dos conceitos geográficos”. In: 14 (ENPEGE) Encontro Nacional de Prática de Ensino de Geografia: Políticas, Linguagens e Trajetórias. Universidade Estadual de Campinas, 29 de junho a 4 de julho de 2019.

MARICATO, E. As ideias fora do lugar e o lugar fora das ideias. In: ARANTES, Otília; VAINER, Carlos; MARICATO, Ermína. A cidade do pensamento único: desmanchando consensos [2000]. Petrópolis, RJ: Vozes, 2000. p.121-192.

Vozes, 2013.

Brasil, cidades: alternativas para a crise urbana. 7. ed. - Petrópolis, RJ: Editora

Metrópole na periferia do capitalismo: ilegalidade, desigualdade e violência.

São Paulo: Hucitec, 1996.

. Para entender a crise urbana. São Paulo: Expressão Popular, 2015.

MARICATO, E.; et al. Cidades rebeldes: passe livre e as manifestações que tomaram as ruas do Brasil. - 1. ed. - São Paulo: Boitempo/Cata Maior, 2013.

MARINO, A. Ação cultural e territórios insurgentes: uma pesquisa-ação com coletivos culturais de São Paulo e Bogotá / Aluízio Marino. - 2016. Dissertação (Mestrado em Planejamento e Gestão do Território) - Universidade Federal do ABC (UFABC), Santo André, 2016.

MASSIMETTI, F. T. “(À) margem da cidade: o extremo sul de São Paulo”. Trabalho Final de Graduação - Faculdade de Arquitetura e Urbanismo, Universidade de São Paulo, 2016.

MASSIMETI, F. T.; BASSANI, J; RODRIGUES, M. “Cultura e identidade: a ressignificação do território da ilha do Bororé”. In: III UrbFavelas, 2018.

“Contracartografia do Grajaú: Repensando o território a partir das vivências”. In:

Seminário Internacional Urbanismo Biopolítico Belo Horizonte - De 24 a 27 de Julho de 2018. 
MIGNOLO, W. "Os esplendores e as misérias da "ciência”: Colonialidade, geopolítica do conhecimento e pluri-versalidade epistêmica”. In: SANTOS, B. S. (org.) Conhecimento prudente para uma vida decente: "Um discurso sobre as ciências" revisitado. São Paulo, Cortez, 2004, pp. 667-709.

MINAYO, M. C. S. “Análise qualitativa: teoria, passos e fidedignidade”. In: Ciência \& Saúde Coletiva, 17(3):621-626, 2012.

MONDARDO, M. "O território como ferramenta analítica no ensino de geografia: dos dispositivos de controle à produção de multi/transterritorialidades”. In: Revista Brasileira de Educação em Geografia, Campinas, v. 5, n. 9, p. 122-139, jan./jun., 2015.

MORAES, A. C. R. Território na geografia de Milton Santos. São Paulo: Annablume, 2013.

MORAES, J. V. A alfabetização científica, a resolução de problemas e o exercício da cidadania: uma proposta para o ensino de geografia. São Paulo: s.n., 2010. 246 p. il., grafs. Tabs. Tese (Doutorado - Programa de Pós-Graduação em Educação. Área de Concentração: Ensino de Ciências e Matemática) - Faculdade de Educação da Universidade de São Paulo.

MOREIRA, M. A. “Aprendizagem significativa: um conceito subjacente (Meaningful learning: an underlying concept)”. In: Aprendizagem Significativa em Revista/Meaningful Learning Review - V1(3), pp. 25-46, 2011. Disponível em: http://www.if.ufrgs.br/asr/artigos/Artigo_ID16/v1_n3_a2011.pdf; http://moreira.if.ufrgs.br/. Acesso em: 15 jan. 2020.

MORHY, P. E. D.; TERÁN, A. F.; FONSECA, A. P. M. “O tema água em espaços não formais: possibilidades de aprendizagem em ciências”. In: BATISTA, N. L.; FLETRIN, T.; RIZZATTI, M. (orgs.) Formação, Prática e Pesquisa em Educação 2 [recurso eletrônico]. - Ponta Grossa, PR: Atena Editora, 2019. - (Formação, Prática e Pesquisa em Educação; v. 2).

NETO, D. P.; SILVA, S. D. M. "Ensino e utilização das categorias geográficas de território e paisagem para licenciatura em educação do campo na área de ciências da natureza e matemática”. In: Revista do centro de ciências da educação, vol. 36, nº 4 - p. 1169-1185, out. /dez. 2018 - Florianópolis.

NOVAK, J. D.; CAÑAS, A. J. “A teoria subjacente aos mapas conceituais e como elaborá-los e usá-los”. Tradução Luis Fernando Cerri (PPGE/UEPG), revisão técnica de Fabiano Morais. In: Práxis Educativa, Ponta Grossa, v.5, n.1, p. 9-29, jan.-jun. 2010. Disponível em http://www.periodicos.uepg.br. Acesso em: 10 out. 2019.

OLIVEIRA, M. K. "Vigotski e o processo de formação de conceitos”. In: TAILLE, Y. L.; OLIVEIRA, M. K., DANTAS, H. Piaget, Vigotski, Wallon: teorias psicogenéticas em discussão. - São Paulo: Summus, 2019. 
PADILHA, P. R. "Município que Educa: caminhos percorridos, itinerários sonhados" (Apresentação). In: PADILHA, P. R.; CECCON, S.; RAMALHO, P. (orgs.). Município que educa: múltiplos olhares. - São Paulo: Editora e Livraria Instituto Paulo Freire, 2010.

PALLAMIN, V. M. Arte, cultura e cidade: aspectos estético-políticos contemporâneos. - São Paulo: Annablume, 2015.

PELLEGRINI, A. L. T. A. "Trabalho, moradia, saúde e cultura: entrelaçando relações: uma experiência em pesquisa-ação a partir do PSF Recanto dos Humildes, Perus”. São Paulo, 2011. 223 f. Dissertação (Mestrado) - Universidade Federal de São Paulo, 2011.

PINTO, V. C. “A ordem urbanística.” Belo Horizonte: Editora Fórum Ltda, 2013. Disponível em: https://www.academia.edu/37555716/A_Ordem_Urban\%C3\%ADstica?auto=download Acesso em: 25 fev. 2020.

PMSP; CEPAL; UNU (orgs.). América Latina: crise nas metrópoles (texto baseado nas teses, depoimentos e debates apresentados no seminário "As Metrópoles Latino-Americanas frente à crise: experiências e políticas”, São Paulo, 1984). - São Paulo: Sempla, 1985.

POCHMANN, M. Políticas públicas e situação social na primeira década do século XXI. In: SADER, E. (org.) 10 anos de governos pós-neoliberais no Brasil: Lula e Dilma. - São Paulo, SP: Boitempo; Rio de Janeiro: FLACSO Brasil 2013.

PREFEITURA DO MUNICÍPIO DE SÃO PAULO. Área de proteção ambiental BororéColônia, $2020 . \quad$ Disponível em:< https://www.prefeitura.sp.gov.br/cidade/secretarias/meio_ambiente/unid_de_conservacao/apa _bororecolonia/index.php?p=41963>. Acesso em 24 fev. 2021.

PREFEITURA DO MUNICÍPIO DE SÃO PAULO. Caderno de Propostas dos Planos Regionais das Subprefeituras Perímetros de Ação - Secretaria Municipal de Desenvolvimento Urbano - SMDU/SP, 2016.

PREFEITURA DO MUNICÍPIO DE SÃO PAULO. Caderno de Propostas dos Planos Regionais das Subprefeituras Quadro Analítico - Secretaria Municipal de Desenvolvimento Urbano - SMDU/SP, 2016.

QUEIROGA, E. F. Dimensões públicas do espaço contemporâneo: resistências e transformações de territórios, paisagens e lugares urbanos brasileiros. 2012. 284 p. Tese (Livre Docência em Arquitetura e Urbanismo) - Faculdade de Arquitetura e Urbanismo, Universidade de São Paulo, São Paulo, 2012.

RAFFESTIN, C. Por uma geografia do poder. São Paulo: Ática, 1993.

RAIMUNDO, S. L. Território, cultura e política: movimento cultural das periferias, resistência e cidade desejada. 274 f. 2017. Tese (Doutorado) - Faculdade de Filosofia, Letras e Ciências Humanas da Universidade de São Paulo, 2017. 
ROCHA, E. N. Das práticas educativas às Políticas Públicas: tramas e artimanhas pela Educação do Campo. Brasília: 2013. Tese (Doutorado - Programa de Pós-Graduação em Educação) - Faculdade de Educação da Universidade de Brasília/UnB.

RODRIGUES, M. “Grajaú: cartografias e identidade.” Mapeamento dos movimentos culturais do Grajaú e proposta de oficinas de cartografia coletiva. Trabalho Final de Graduação Faculdade de Arquitetura e Urbanismo, Universidade de São Paulo, 2017.

ROLNIK, R. Guerra dos lugares: a colonização da terra e da moradia na era das finanças [2015]. 2. ed. - São Paulo: Boitempo, 2019.

Estrelas, 2017.

Territórios em conflito. São Paulo: espaço, história e política. - São Paulo: Três

ROLNIK, R.; CAMPOS, C. M.; NAKANO, K. "Dinâmicas dos subespaços da área central de São Paulo”. In: EMURB. Caminhos para o centro: estratégias de desenvolvimento para a região central de São Paulo / fotografia de Cristiano Mascaro - São Paulo: 2004.

SANDEVILLE JR., E. “A paisagem do município como território educativo”. In: ; __ Município que educa: múltiplos olhares. - São Paulo: Editora e Livraria Instituto Paulo Freire, 2010.

"Paisagens e métodos. Algumas contribuições para elaboração de roteiros de estudo da paisagem intra-urbana”. Paisagens e Debates, FAUUSP, v. 2, p. 1, 2004.

"Por pedagogias participantes e criativas na paisagem e no ambiente". In: Paisagem Ambiente: ensaios - n. 30 - São Paulo - p. 87 - 106 - 2012.

"Programa Universidade Livre e Colaborativa: Processos Colaborativos de Construção do Conhecimento e Aprendizagem em Ação (2003-2012; 2012-2015)”. Núcleo de estudos da Paisagem., on line, São Paulo, 2018. Disponível em: http://ensinoepesquisa.net.br/ http://sandeville.net.br. Acesso em: 15 ago. 2019.

SANDEVILLE JR., E; BASSANI, J. "Paisagens Contemporâneas: Contracultura e Resistência, AUP5883/2019”. A Natureza e o Tempo (o Mundo), online, São Paulo, 2019. Disponível em: <http://biosphera21.net.br/4-ENSINO-PAISAGEMCONTEMPORANEA-2019.html>. Acesso em: 05 jan. 2020.

SANDEVILLE JR., E.; FERNANDES, G.; BORTOTO, R. C. S. "Universidade livre e colaborativa em Perus: uma experiência didático-pedagógica de aprendizagem colaborativa”. In: Arquitectura y calidad socioambiental en ciudades del Cono Sur. Organização: Luis Muller e Maria Lucia Refinetti Martins. (Org.). São Paulo; Buenos Aires: FAU USP (Brasil) e FADU UNL (Argentina), 2016, v., p. 135-147. Disponível em: http://ensinoepesquisa.net.br/ http://sandeville.net.br. Acesso em: 15 ago. 2019. 
SANTOS, B. de S. "A Universidade no século XXI: para uma reforma democrática e emancipatória da universidade”. Educação, Sociedade \& Culturas, n. 23, 2005, pp. 137-202.

SANTOS, M. A Natureza do Espaço: Técnica e Tempo, Razão e Emoção. São Paulo: Editorada da Universidade de São Paulo, 2006.

O Espaço do Cidadão [1987]. - 7. ed., 2. Reimpr. - São Paulo: Editora da Universidade de São Paulo, 2014.

. “O retorno do território”, in. SANTOS, M; SOUZA, M. A.; SILVEIRA, M. L. Território: globalização e fragmentação. 4. ed. - São Paulo: Hucitec, 1998.

. Pensando o Espaço do Homem [1982]. - 5. ed., 3. reimp. - São Paulo: Editora da Universidade de São Paulo, 2012.

SANTOS, M.; SILVEIRA, M. O Brasil: território e sociedade no início do século XXI. Rio de Janeiro: Record, 2001.

SANTOS, M; SOUZA, M. A.; SILVEIRA, M. L. Território: globalização e fragmentação. 4. ed. - São Paulo: Hucitec, 1998.

SAQUET, M. A. Por uma geografia das territorialidades e das temporalidades: uma concepção multidimensional voltada para a cooperação e para o desenvolvimento territorial. 2. ed. - Rio de Janeiro: Consequência, 2015.

Consequência, 2019.

Saber popular, práxis territorial e contra-hegemonia. Rio de Janeiro:

SANTOS, R. M. “APA Bororé: subsídios à implantação - praticando geografia com a teoria dos geossistemas”. Trabalho de Graduação - Faculdade de Filosofia, Letras e Ciências Humanas - Departamento de Geografia. São Paulo, 2003.

SCHWARZ, R. As ideias fora do lugar: ensaios selecionados. - São Paulo: Penguin Classics Companhia das Letras, 2014.

SHIMADA, M. S.; TERÁN, A. F. A relevância dos espaços não formais para o ensino de ciências. In: $4^{\mathbf{0}}$ Encontro Internacional de Ensino e Pesquisa em Ciências na Amazônia. Caballo Cocha - Peru, 06 de dezembro de 2014. Tabatinga - Amazonas - Brasil, 08 a 12 de dezembro de 2014 CESTB/UEA. Disponível em: https://ensinodeciencia.webnode.com.br. Acesso em: 10 jan. 2020.

SIVIERO, F. P. Um mapa para outros fazeres: Territórios educativos e patrimônio cultural. - 2014. Dissertação (Mestrado Profissional em Preservação do Patrimônio Cultural) - Instituto do Patrimônio Histórico e Artístico Nacional, Rio de Janeiro, 2014. 
SINGER, H. (org.). Territórios educativos: experiências em diálogo com o Bairro-Escola São Paulo: Moderna, 2015. — (Coleção territórios educativos; v. 1).

Territórios educativos: experiências em diálogo com o Bairro-Escola - São Paulo: Moderna, 2015. — (Coleção territórios educativos; v. 2).

SOUZA, C. F. "Sevirologia: a arte de sobreviver e construir um território educador”. CENTRO DE PESQUISA E FORMAÇÃO - SESC, Curso de Gestão Cultural, 2020.

SOUZA, L. R. D. Potencialidades do conceito de território e da argumentação para a formação cidadã em aulas de geografia. São Paulo: s.n., 2018. 197 p. Dissertação (Mestrado - Programa de Pós-Graduação em Educação. Área de Concentração: Educação Científica, Matemática e Tecnológica) - Faculdade de Educação da Universidade de São Paulo.

SOUZA, M. L. de. Os conceitos fundamentais da pesquisa sócio-espacial. Rio de Janeiro: Bertrand Brasil, 2020

SOUZA, S. M. C. A importância dos espaços não-formais de ensino na formação de professores do curso de licenciatura em ciências biológicas da Universidade Federal do Pará (UFPA). 2017. Trabalho de Conclusão de Curso - Faculdade de Ciências Biológicas, Modalidade Biologia da Universidade Federal do Pará.

TAILLE, Y. de La. “O lugar da interação social na concepção de Piaget”. In: TAILLE, Y. L.; OLIVEIRA, M. K., DANTAS, H. Piaget, Vigotski, Wallon: teorias psicogenéticas em discussão. - São Paulo: Summus, 2019.

TEIXEIRA, A. “A Escola Parque da Bahia”. Revista Brasileira de Estudos Pedagógicos. Rio de Janeiro, v. 47, n. 106, abr/jun 1967, pp. 246-253. Disponível em: http://www.bvanisioteixeira.ufba.br/. Acesso em 10/10/2019.

. "Bases da teoria lógica de Dewey”. Revista Brasileira de Estudos Pedagógicos. Rio de Janeiro, v. 23, n. 57, jan/mar 1955, pp. 3-27. Disponível em: http://www.bvanisioteixeira.ufba.br/. Acesso em 10/10/2019.

. “Dewey e a filosofia da educação”. Boletim Informativo CAPES. Rio de Janeiro, n. 85, dez/1959, pp. 1-2. Disponível em: http://www.bvanisioteixeira.ufba.br/. Acesso em 10/10/2019.

. "Porque Escola Nova”. Boletim da Associação Bahiana de Educação. Salvador, n. 1, 1930, pp. 2-30. Disponível em: http://www.bvanisioteixeira.ufba.br/. Acesso em 10/10/2019.

TEODOSIO, T. S. J. Espaço Maré: histórias, trajetórias e desafios. Rio de Janeiro, 2006. Dissertação (Mestrado em Estudos Populacionais e Pesquisas Sociais, Área de Concentração: População, sociedade e território) - IBGE/ENCE. 
THIOLLENT, M. “Maio de 1968 em Paris: testemunho de um estudante”. Tempo Social; Rev. Sociol. USR S. Paulo, 10(2): 63-100, outubro de 1998.

TORRES, R. M. (org.). Educação popular: um encontro com Paulo Freire. São Paulo: Loyola, 1987.

TORRES, P.; IRALA, E. “Aprendizagem colaborativa: teoria e prática”. In: TORRES, P. (org.). Complexidade: Redes e Conexões na Produção do Conhecimento. Curitiba: SENAR - PR, 2014. pp.61-94. Disponível em: https://www.agrinho.com.br/site/wpcontent/uploads/2014/09/00_Pretextuais_Livro_2.pdf . Acesso em: 20 nov. 2019.

TRILLA, J. “A educação não-formal”. In: TRILLA, J.; GHANEM, E.; ARANTES, V. A. (org). Educação formal, não-formal: pontos e contrapontos. - São Paulo: Summus, 2008. (Coleção pontos e contrapontos)

TRILLA, J.; GHANEM, E.; ARANTES, V. A. (org). Educação formal, não-formal: pontos e contrapontos. - São Paulo: Summus, 2008. - (Coleção pontos e contrapontos)

UNIVERSIDADE de São Paulo. Agência USP de Gestão da Informação Acadêmica Diretrizes para apresentação de dissertações e teses da USP : parte I (ABNT) / Agência USP de Gestão da Informação Acadêmica; Vânia Martins Bueno de Oliveira Funaro, coordenadora; Vânia Martins Bueno de Oliveira Funaro [et al.]. 4.ed. São Paulo: AGUIA, 2020. 76p.

VAINER, C. Cidade de exceção: reflexões a partir do Rio de Janeiro. Anais do XIV Encontro Nacional da ANPUR. Rio de Janeiro, 23 a 27 de maio de 2011.

VICTORINO-RAMÍREZ, L.; VELÁZQUEZ-RODRÍGUEZ, E. B.; RUÍZ-GONZÁLEZ, R. O. Environmental education, territoriality and interculturality, from the sustainable to the 'good living’ in latinoamérica. In: Ra Ximhai, vol. 10, Número 3 Edición Especial, Enero - Junio 2014.

VICENTE, P. M.; LIMA, C. P. C. S. "Parque Pinheirinho d’Água: a construção coletiva do espaço público”. In: XVII ENANPUR, 2017.

VILLAÇA, F. O espaço intra-urbano no Brasil [1998]. São Paulo, Studio Nobel/Lincoln Institute, 2001.

. “Uma contribuição para a história do planejamento urbano no Brasil”. In: DEÁK, C.; SCHIFFER, S. R. (org.). O processo de urbanização no Brasil. São Paulo: EdUSP, 1999. p. $169-243$.

VILUTIS, L. "Município que Educa: ação cultural por uma nova cultura política”. In: PADILHA, P. R.; CECCON, S.; RAMALHO, P. (orgs.). Município que educa: múltiplos olhares. - São Paulo: Editora e Livraria Instituto Paulo Freire, 2010. 
VYGOTSKY, L. S. A formação social da mente. - 4. ed. brasileira. - São Paulo: Martins Fontes, 1991.

Pensamento e Linguagem [1934]. São Paulo: Edição eletrônica Ed Ridendo Castigat Mores, 2001. Versão eletrônica (Versão para eBook). Disponível em: www.ebooksbrasil.org. Acesso em: 20 jan. 2020.

WALLERSTEIN, I. Análisis de Sistemas-Mundo: una introducción. Siglo veintiuno editores, [s.d.].

WESTBROOK, R. B. “John Dewey”. In: WESTBROOK, R. B.; TEIXEIRA, A.; ROMÃO, J. E.; RODRIGUES, V. L. (org.). John Dewey - Recife: Fundação Joaquim Nabuco, Editora Massangana, 2010.

\section{Legislação:}

PREFEITURA DO MUNICÍPIO DE SÃO PAULO. Decreto ${ }^{0}$ 55.955, de 26 de fevereiro de 2015. Estabelece as condições a serem observadas na implantação de equipamentos públicos sociais municipais na Cidade de São Paulo, nos termos do parágrafo único do artigo 276 da Lei $\mathrm{n}^{\mathrm{o}}$ 16.050, de 31 de julho de 2014 - Plano Diretor Estratégico. Disponível em: http://legislacao.prefeitura.sp.gov.br/leis/decreto-55955-de-26-de-fevereiro-de-2015. Acesso em: 20 set. 2019.

Decreto $n^{0}$ 56.725, de 16 de dezembro de 2015. Regulamenta disposições da Lei $\mathrm{n}^{0}$ 16.050, de 31 de julho de 2014 - Plano Diretor Estratégico, relativas às Zonas Especiais de Preservação Cultural - Área de Proteção Cultural - ZEPEC/APC. Disponível em: http://legislacao.prefeitura.sp.gov.br/leis/decreto-56725-de-16-de-dezembro-de-2015. Acesso em: 20 set. 2019.

. Decreto ${ }^{0} 58.963$ de 24 de setembro de 2019. Regulamenta o artigo 276 da Lei $\mathrm{n}^{\mathrm{o}} 16.050$, de 31 de julho de 2014, e estabelece as condições a serem observadas para a implantação de equipamentos públicos sociais nas áreas públicas e no Sistema de Áreas Protegidas, Áreas Verdes e Espaços Livres (SAPAVEL), disciplinadas nos artigos 27 a 33 da Lei $\mathrm{n}^{\circ}$ 16.402, de 22 de março de 2016. Disponível em: http://legislacao.prefeitura.sp.gov.br/leis/decreto-58963-de-24-de-setembro-de-2019. Acesso em: 10 jan. 2020.

. Lei $\mathrm{n}^{0} 13.549$ de 1 de abril de 2003. Dispõe sobre a implantação do Centro Cultural da Fábrica de Cimento Portland Perus e do Centro Temático da Estrada de Ferro Perus/Pirapora, integrados ao Parque Anhangüera e dá outras providências. Disponível em: http://legislacao.prefeitura.sp.gov.br/leis/lei-13549-de-01-de-abril-de-2003. Acesso em: 20 set. 2020. 
Lei $n^{\circ} 16.050$ de 31 de julho de 2014. Aprova a Política de Desenvolvimento Urbano e o Plano Diretor Estratégico do Município de São Paulo e revoga a Lei n ${ }^{\circ} 13.430 / 2002$. Disponível em: http://legislacao.prefeitura.sp.gov.br/leis/lei-16050-de-31-de-julho-de-2014. Acesso em: 10 set. 2019.

. Lei $n^{\circ} 16.402$ de 22 de março de 2016. Disciplina o parcelamento, o uso e a ocupação do solo no Município de São Paulo, de acordo com a Lei no 16.050 , de 31 de julho de 2014 - Plano Diretor Estratégico (PDE). Disponível em: http://legislacao.prefeitura.sp.gov.br/leis/lei-16402-de-22-de-marco-de-2016. Acesso em: 10 set. 2019.

\section{Sites:}

DA

TERRA.

Disponível

em:

http://www.ebooksbrasil.org/adobeebook/cartadaterra.pdf. Acesso em: 20 set. 2019.

GRUPO DE ESTUDOS MAPOGRAFIAS URBANAS FAUUSP. Disponível em: https://gemapfau.wixsite.com/fauusp. Acesso em: 10 ago. 2019.

MOVIMENTO FÁBRICA DE PERUS. Disponível em: https://movimentofabricaperus.wordpress.com/ . Acesso em: 15 ago. 2019.

MOVIMENTO FÁBRICA PERUS. Quem somos. Disponível em: https://movimentofabricaperus.wordpress.com/sobre-o-movimento/quem-somos/ . Acesso em 24 fev. 2021.

TERRITÓRIOS DE INTERESSE DA CULTURA E DA PAISAGEM EM SÃO PAULO TICP. Disponível em: http://biosphera21.net.br/5-TICP.html. Acesso em: 15 ago. 2019. 


\section{ANEXO I}

\section{FACULDADE DE ARQUITETURA E URBANISMO DA UNIVERSIDADE DE SÃO PAULO PROGRAMA DE PÓS GRADUAÇÃO}

\section{TERMO DE CONSENTIMENTO LIVRE E ESCLARECIDO}

Declaro por meio deste termo, que concordei em ser entrevistado (a) no dia/mês/ano referente a pesquisa de mestrado "Território Educativo: as práticas educativas da extensão universitária e dos coletivos culturais na periferia de São Paulo”, desenvolvido no Programa de PósGraduação em Arquitetura e Urbanismo da FAUUSP, com apoio do Grupo de Estudos de Mapografias Urbanas (GeMAP), sob orientação do professor Dr. Jorge Bassani.

Afirmo que aceitei participar de forma voluntária, sem receber qualquer incentivo financeiro ou ter qualquer ônus e com a finalidade exclusiva de colaborar para o sucesso da pesquisa. Fui informado (a) do objetivo estritamente acadêmico do estudo, que em linhas gerais objetiva compreender as relações entre território e educação, por meio das práticas educativas da extensão universitária e dos coletivos territorializados em Perus e no Bororé.

Fui informado (a) que o uso das informações por mim oferecidas estão submetidos às normas éticas destinadas à pesquisa.

Fui informado (a) de que as informações que constam na entrevista gravada poderão ser usadas para fins acadêmicos, com a possibilidade da utilização de alguns trechos das entrevistas sob a forma de citação ou referência na divulgação dos resultados da pesquisa, com a identidade do (a) participante a ser preservada. O resultado da pesquisa será divulgado a partir de uma dissertação de mestrado, no $1^{\text {o }}$ semestre de 2021, podendo também ser apresentado em eventos científicos nacionais e internacionais. O acesso e a análise dos dados coletados se darão apenas pela pesquisadora e por seu orientador.

Fui também informado (a) que poderia interromper essa pesquisa/entrevista a qualquer momento, sem prejuízo para meu acompanhamento ou sofrer quaisquer constrangimentos. Atesto o recebimento de uma cópia assinada deste Termo de Consentimento Livre e Esclarecido.

de de 20

Local e data 
Nome do (a) participante

Assinatura do (a) participante

Analu Garcia Borges

Mestranda do PPGAU-FAUUSP 


\section{ANEXO II}

\section{FACULDADE DE ARQUITETURA E URBANISMO DA UNIVERSIDADE DE SÃO PAULO PROGRAMA DE PÓS GRADUAÇÃO}

\section{TERMO DE CONSENTIMENTO LIVRE E ESCLARECIDO}

Declaro por meio deste termo, que concordei em ser entrevistado (a) no dia/mês/ano referente à pesquisa “Conceituação e Perimetrização de Território para um TICP”, coordenada pelo prof. Dr. Jorge Bassani (GeMAP/FAUUSP) e colaboradores prof. Dr. Euler Sandeville Junior (LABCIDADE/FAUUSP), profa. Dra. Lilian Amaral (DIVERSITAS/ECAUSP), Analu Garcia Borges (mestranda FAUUSP-PlanUrb) e Diego Fernandes (graduando ECAUSP e bolsista PUB do projeto).

Afirmo que aceitei participar de forma voluntária, sem receber qualquer incentivo financeiro ou ter qualquer ônus e com a finalidade exclusiva de colaborar para o sucesso da pesquisa. Fui informado (a) do objetivo estritamente acadêmico do estudo, que em linhas gerais objetiva aprofundar os conceitos de territórios culturais e paisagem.

Fui informado (a) que o uso das informações por mim oferecidas estão submetidos às normas éticas destinadas à pesquisa.

Fui informado (a) de que as informações que constam na entrevista gravada poderão ser usadas para fins acadêmicos, com a possibilidade da utilização de alguns trechos das entrevistas sob a forma de citação ou referência na divulgação dos resultados da pesquisa, com a identidade do (a) participante a ser preservada. O resultado da pesquisa será divulgado a partir de relatórios e artigos, podendo também ser apresentado em eventos científicos nacionais e internacionais. O acesso e a análise dos dados coletados se darão apenas pelos pesquisadores e pelo coordenador da pesquisa.

Fui também informado (a) que poderia interromper a entrevista a qualquer momento, sem prejuízo para meu acompanhamento ou sofrer quaisquer constrangimentos.

Por fim, autorizo o uso do conteúdo da entrevista pela participante do programa Analu Garcia Borges, em sua dissertação de mestrado “Território Educativo: as práticas educativas da extensão universitária e dos coletivos culturais na periferia de São Paulo”, desenvolvido no Programa de Pós-Graduação em Arquitetura e Urbanismo da FAUUSP, com apoio do Grupo de Estudos de Mapografias Urbanas (GeMAP), sob orientação do professor Dr. Jorge Bassani. 
Fui informado (a) de que as informações que constam na entrevista gravada poderão ser usadas para fins acadêmicos, com a possibilidade da utilização de alguns trechos das entrevistas sob a forma de citação ou referência na divulgação dos resultados da pesquisa, com a identidade do (a) participante a ser preservada. O resultado da pesquisa será divulgado a partir de uma dissertação de mestrado no $1^{\circ}$ semestre de 2021, podendo também ser apresentado em eventos científicos nacionais e internacionais por meio da publicação de artigos. O acesso e a análise dos dados coletados se darão apenas pela mestranda e pelo seu orientador.

Atesto o recebimento de uma cópia assinada deste Termo de Consentimento Livre e Esclarecido.

de de 20

Local e data

Nome do (a) participante

Assinatura do (a) participante

Analu Garcia Borges

Mestranda do PPGAU-FAUUSP

Jorge Bassani

Coordenador da pesquisa e Orientador do Mestrado do PPGAU-FAUUSP 


\section{ANEXO III - CERTIFICADO DE DEFESA}

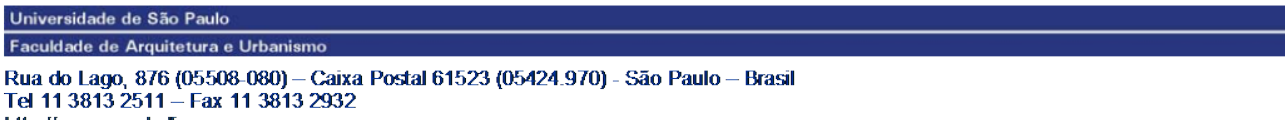

Tet 1138132511 -Fax 1138132932

http/horw usp brfau

\section{CERTIFICADO DE DEFESA DE MESTRADO NÄO PRESENCIAL}

Certifico que em 15 de janeiro de 2021 realizou-se a defesa de Dissertaçāo nāo presencial do(a) aluno(a) Analu Garcia Borges, de maneira remota, por meio da seguinte plataforma de conferência online:

Goolge-meet:m eet.google.com/fof-nump-ukh

Participaram da banca os docentes:

Presidente Prof(a) Dr(a) Jorge bassani

Prof(a) Dr(a) Silvia Lopes Raimundo

Prof(a) Dr(a) Bruno Cesar Euphrasio de Mello

A defesa iniciou-se às 10:00 e encerrou-se às $12: 30$

Comentários dos membros da banca (opcional):

A banca consensualmente destaca a relevância e rigor da dissertaçāo e indica para a publicaçāo

Resultado final: Aprovada , conforme Ata por mim preenchida e enviada em anexo.

Solicita-se que, sempre que possível, a depender da plataforma utilizada, a parte da leitura do resultado final seja gravada para registro.

Sobre as informaçōes acima, dou fé.

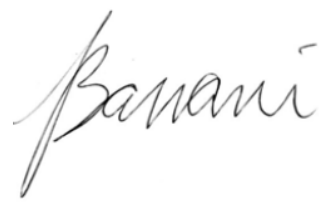

Prof. Dr. Jorge Bassani 